Historic, archived document

Do not assume content reflects current scientific knowledge, policies, or practices. 



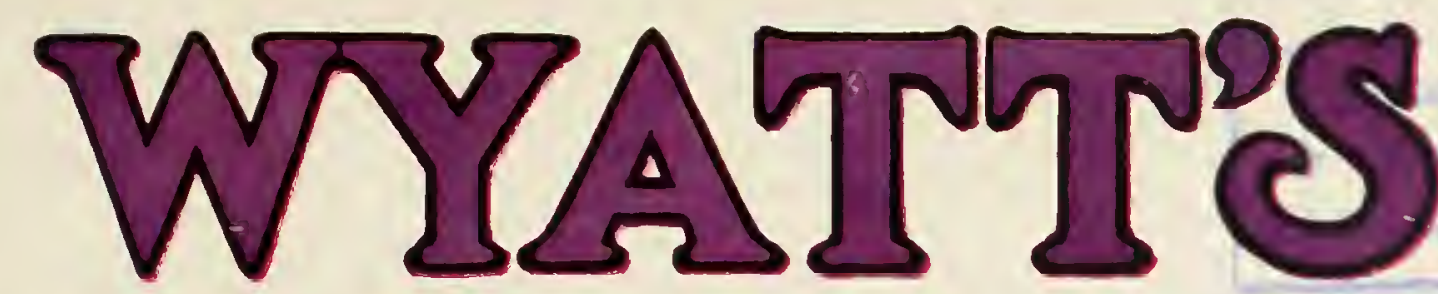

\section{GARDEN GUIDE}

\section{6}

Established 1881

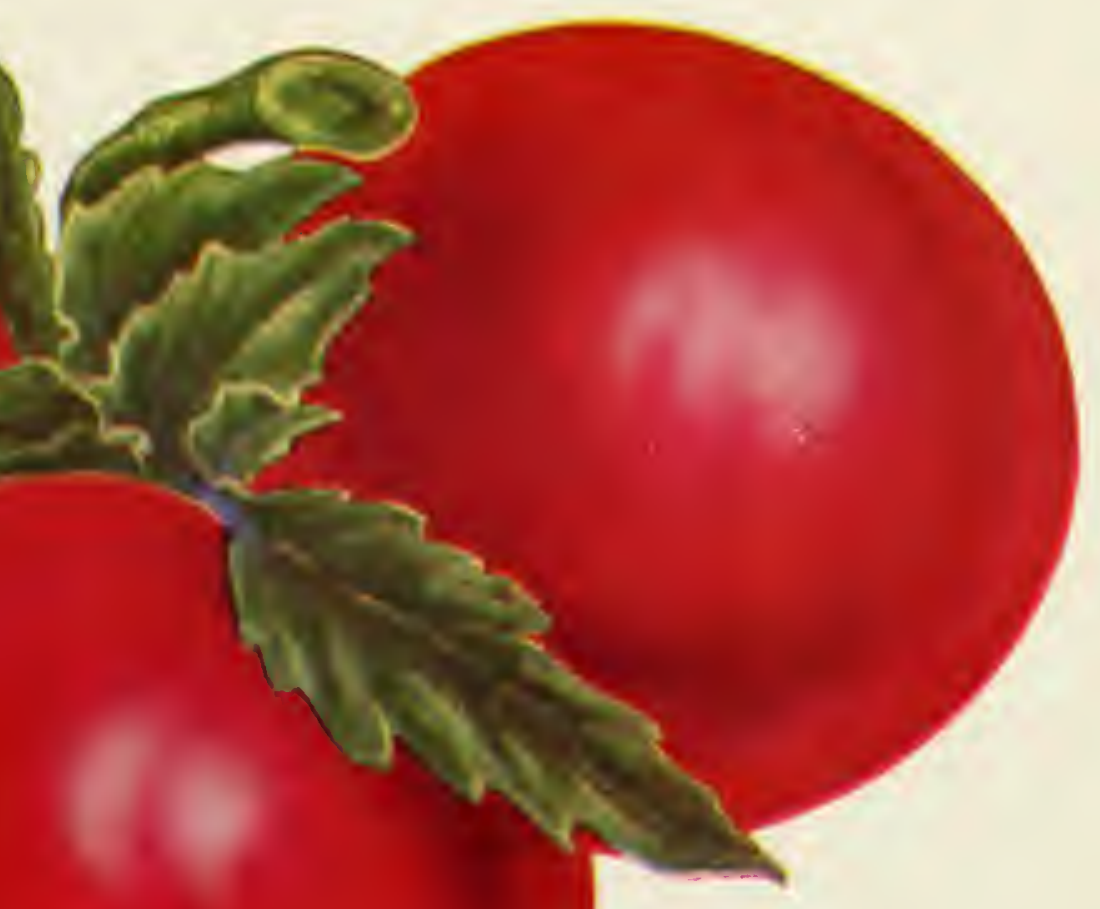

WYATT"S

BBIRIMMIEIR TOMATO

(siclected Strain)

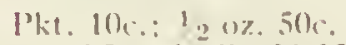

$10 \% 750.1,11 \%, \$ 2.25$

I II) Ss.t)(

\section{THE LEADING SEED HOUSE OF THE CAROLINAS}

\section{JOB P. WYAT'T \& SONS CO. RALEIGH, N. C.}




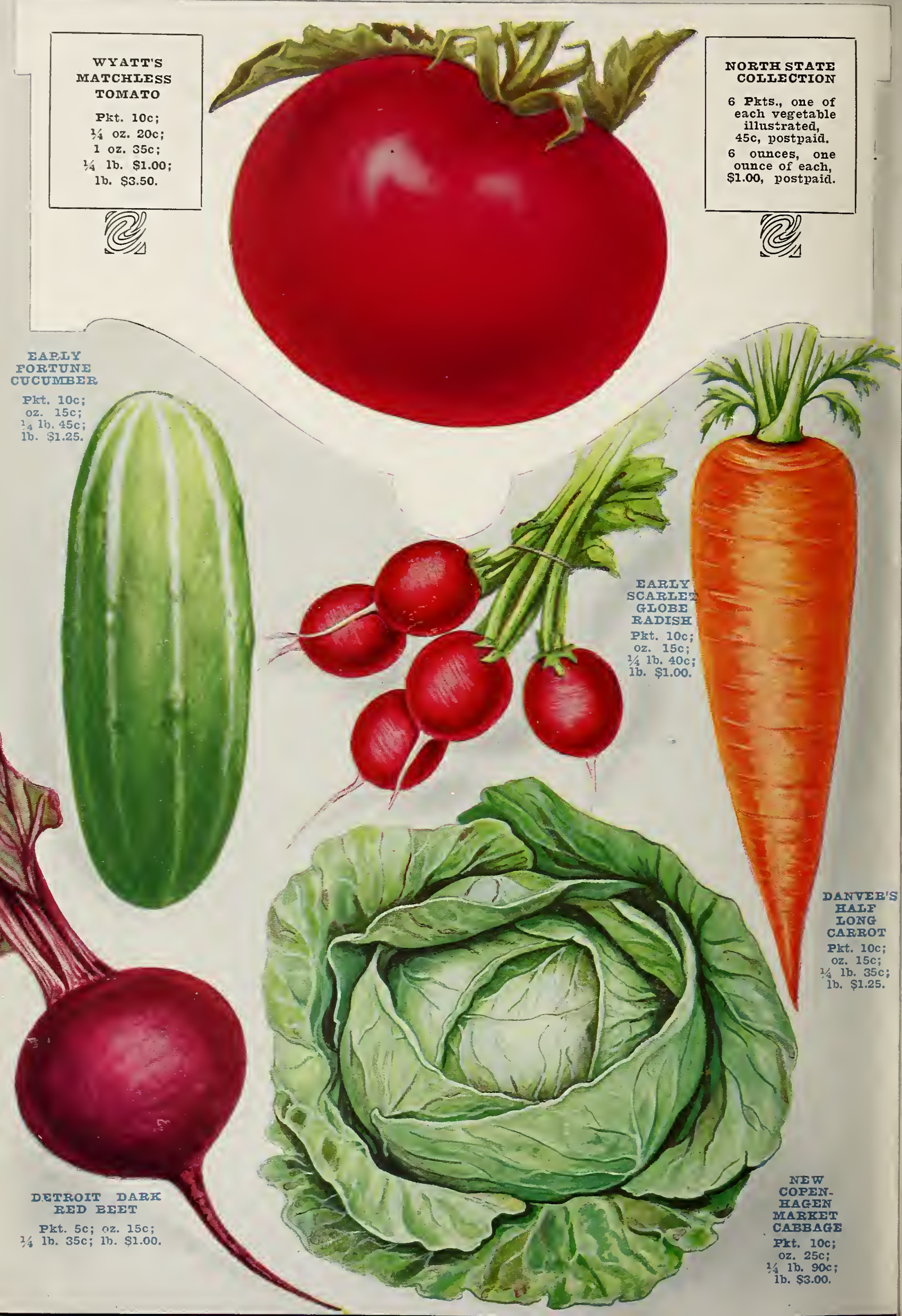




\section{TO OUR PATRONS AND FRIENDS}

January 1, 1926.

We wish to thank our many customers for their patronage during 1925. In presenting this our 1926 catalogue we assure you that any orders entrusted to us will receive the best care and attention.

The following suggestions will enable you to fill out your order quickly and our ship. ping department will then be able to handle it with no loss of time.

Do not Delay Ordering until you are ready to use the goods you want. It will prove economical often to anticipate your wants. The loss of time in planting by delays of transportation companies, also advances in prices, should show the wise buyer that it is to his interest to order early.

Save Money. When you make out your general list of Seed, be sure to include In. secticides and Sprayers, also fertilizers, with your order; thereby you will be saving extra express or freight charges. Remember. when the bugs or insects appear on your crop. you need insecticides; then delay getting the remedy and sprayers may cost you ten times the cost of your purchase.

How to Send an Order. You will find in the back of this book an order sheet, perforated for tearing out; also an addressed envelope in which to send the order. When convenient, always use this order sheet. Please do not write anything on the sheet except items wanted and what pertains to the order. Write on separate sheet when asking for prices or information; this will avoid the possibility of being overlooked; also insure quick attention to information asked.

Alnska Peas

See page 23

Please be careful to sign your name, postolfice, county, and state on each order and letter sent us. Each year we receive orders without name or address ol sender.

Terms. All orders, to secure prompt shipment, should be accompanled with the cash. We can only send to well rated merchants, or parties well known to us, without the cash with order. When remittance falls short of amount of goods ordered, it is our custom to reduce the quantity sent, Instead of delaying order by writing.

How to Send Money. By Post-Office or Express Money Order, Bank Check, or Draft. Cash by Registered Letter. We accept clean postage stamps for small amounts the same as cash.

C. O. D. Orders must be accompanied by a remittance equal to one-fourth the amount of the order; thil insures the express or freight charges in case the goods are not taken when they arrive at destinatlon.

Postage on Seeds. We pay the postage on packets, ounces, and quarter-pound packages; also where prepaid postage prices are given. For large quantities, see parcel post rates in table given below.

Parcel Post Rates on Bulbs, Plants and Seeds. Seed rate, 2 ounces for one cent, up to 8 ounces. Above 8 ounces the local and zone parcel post rates are applied.

Prices on Field Seeds, Onlon Sets, and Potatoes are constantly fluctuating. The prices glven are those ruling at the time this catalogue is printed but they are not blading, and may change at any tlmo. We will cheerfuliy quote prices at any time on request. and wlll always fill open orders entrusted to us at the loweet rates possible for our best quality seeds. It Irequently occurs that the prices of artlcles may have changed between the time our catalog is printed and recelpt of orders. When such is the case, if the article ordered lo cheaper, we will send the value of such artlcles at the ruling prices. If the articles are higher, we will deduct the quantity to meet the amount of remittances. But in case you wish to limit your price, please so state on your order otherwise we will fll your order as we think best.

About Warranting Seeds. We exercise the great eat possible care in growing, buying, examining. and test ing our seeds, and we try in every department of the business to guard against mistakes and insure rellability. and under certain conditions and with proper cultivation they will certainly grow good crops. yet no seeds. men can, or ever does in good faith, assume any responsibility for crops grown from seeds oupplied by him, there being too many causes, known and unknown, which prevent good eeds from germinating. Therefore, in common with all responsible seed houses, we sell our goods subject to the following, and all orders gent us will be accepted under these conditions only: Job P. IVyatt \& Sons Co. give no warranty, expressed orl mplied, as to growth, description, quality, productlveness, or any other matter of any seeds, bulbs. or plants they send out, and they will not be responaible in any way for the crop.

To Those Who Have Never Planted Our Seeds.

We are very anxious that you send us a trial order this year, and we know that the fine crops our seeds produce for you will please you so well that you will send us your full order next year.

JOB P. WYATT \& SONS CO.,
Raleigh, N. C.

\begin{tabular}{|c|c|c|c|c|c|c|c|c|c|}
\hline \multicolumn{10}{|c|}{ PARCEL POST RATES } \\
\hline $\begin{array}{l}\text { n } \\
\text { z } \\
0 \\
0 \\
0\end{array}$ & & 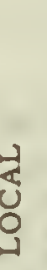 & 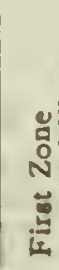 & $\begin{array}{l}\frac{0}{2} \\
\frac{0}{2} \\
0 \\
0 \\
0 \\
0\end{array}$ & 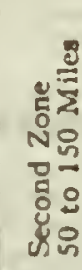 & 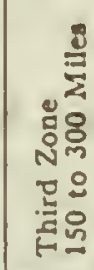 & 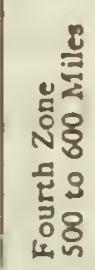 & & $\begin{array}{l}\frac{8}{3} \\
8 \\
8 \\
8 \\
0 \\
8 \\
8 \\
8\end{array}$ \\
\hline 1. & & 07 & 180 & 07 & 5007 & 15008 & 15000 & 50 & 10 \\
\hline 2. & & 08 & & 08 & 08 & 10 & 13 & & 16 \\
\hline 3. & & 08 & & 09 & 09 & 12 & 17 & & 22 \\
\hline 4. & & 09 & & 10 & 10 & 14 & 21 & & 28 \\
\hline 5. & & 09 & & 11 & 11 & 16 & 25 & & 34 \\
\hline 6. & & 10 & & 12 & 12 & 18 & 29 & & 40 \\
\hline 7. & & 10 & & 13 & 13 & 20 & 33 & & 46 \\
\hline 8. & & 11 & & 1.8 & 1.8 & 22 & 37 & & 52 \\
\hline 9. & & 11 & & 15 & 15 & 24 & 41 & & 58 \\
\hline 10. & & 12 & & 16 & 16 & 26 & 45 & & 64 \\
\hline 11. & & 12 & & 17 & 17 & 28 & 49 & & 70 \\
\hline 12. & & 13 & & 18 & 18 & 30 & 53 & & 76 \\
\hline 13. & & 13 & & 19) & 19 & 32 & 57 & & 82 \\
\hline 14. & & 14 & & 20 & 20 & 34 & 61 & & 88 \\
\hline 15. & & 14 & & 21 & 21 & 36 & 65 & & 94 \\
\hline 16. & & 15 & & 22 & 22 & 38 & 69 & & 00 \\
\hline 17. & & 15 & & 23 & 23 & 40 & 73 & 1 & 06 \\
\hline 18. & & 16 & & 24 & 24 & 42 & 77 & 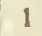 & 12 \\
\hline 19. & & 16 & & 25 & 25 & 44 & 81 & 1 & 18 \\
\hline 20. & & 17 & & 26 & 26 & 46 & 85 & & 24 \\
\hline
\end{tabular}

\section{Diversified Farming Pays Best}




\title{
Vegetable Novelties
}

\author{
Make Gardening a Real Pleasure
}

Our Specialties offered here are varieties that will give satisfaction. Include a few Novelties in your order. The Novelties are new varieties and sometimes represent an entirely new class of vegetables. A great deal of the pleasure of gardening lies in discovering something new_and in being pleasantly surprised. These Novelties will help you win prizes at exhibitions_and will certainly excite the wonder of yourfriends.

\section{Fordhook Favorite Beans}

\section{A While Seeded Stringless Green Pod.}

This is a green podded bean, perfectly stringless, with white seeds, which can be used for soup or baked beans all winter.

The bush grows from 18 to 20 inches high, with dark green foliage, producing an enormous yield of beautiful, meaty, almost round, green pods averaging $51 / 2$ to $61 / 2$ inches long. Ready for picking in 45 days. Pkt. $10 \mathrm{cts.}$ lb. 35 cts., prepaid. Not prepaid: 3 lbs. 90 cts., 10 lbs. $\$ 2.75$.

\section{Speckled Pole Lima Beans}

Is a mottled bean, white streaked and spotted red. The quality is excellent and it is a prolific yielder. Pkt. 10 cts., lb. 35 cts., postpaid; 10 lbs. $\$ 2.75$.

\section{The "Yard Long" Bean}

\section{Asparagus Bean}

Pods are nearly up to the name, often reaching a length of 30 to 36 in., but usually 18 to 24 in. Your friends will wonder at and admire your plants of this great bean, and they are of excellent table quality also, with a rich asparagus flavor. Do not be without this valuable curiosity. It is a pole bean of quick growth, with neat foliage, not attacked by inse.,ts. Pkt. 10 cts., 1/4 lb. 50 cts., lb. $\$ 1.50$.

\section{Davis' Kidney Wax Beans}

It is a reliable and exceedingly heavy yielder. with the merit of maturing early and very evenly. The pods are attractive, being long and straight and of a beautiful waxy white that does not discolor in cooking. The seeds are pure white, kidney shaped and are excellent for cooking either green or dry. Pkt. 10 cts.. lb. 35 cts., 10 lbs. $\$ 2.50$.

\section{Jackson's Wonder Bush Lima}

In habit of growth is very similar to Henderson Bush Lima. The dry seed is larger and mottled in dark red and brown. Pkt. 10 cts., 1b. 35 cts., 10 lbs. $\$ 2.75$.

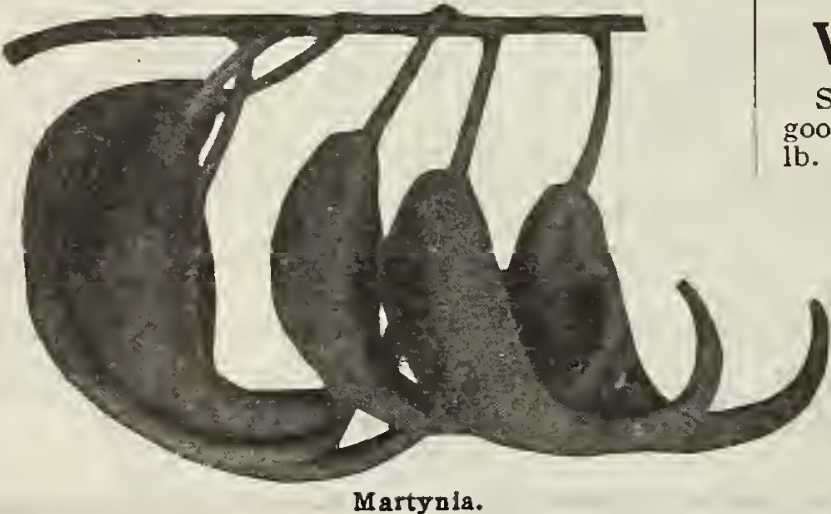

[ 2 ]

\section{Early Model Deep Red Beet}

An excellent variety for Carolina market gardeners. Pkt. 10 cts., 1 oz. 15 cts., $1 / 4$ lb. 35 cts., 1 lb. $\$ 1.25$., 5 lbs. $\$ 5.00$.

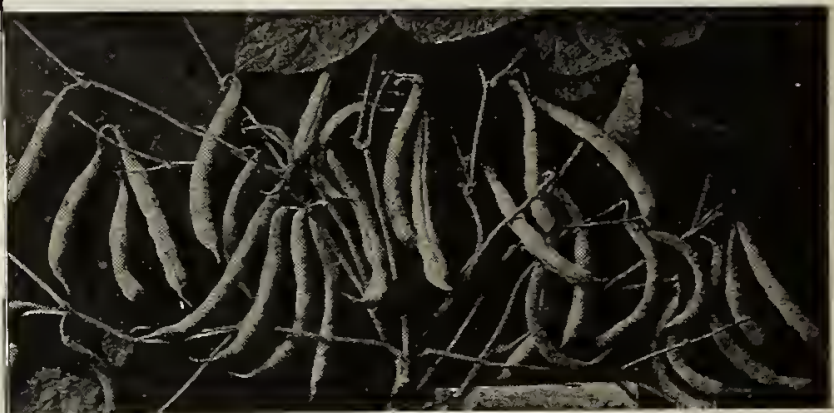

Fordhook Favorite Beans

\section{Tennessee Green Pod Beans}

A green pod variety that is wonderfully productive. Pkt. 10 cts., 1 lb. 35 cts., 2 lbs. 65 cts.

\section{Black Diamond Cucumber}

A small extremely early, intense green variety. Pkt. 10 cts., 1 oz. 35 cts., $1 / 4$ ib. $\$ 1.00$.

\section{Black Russian Cucumber}

The smallest cucumber grown. Best for small pickles. Pkt. 10 cts., 1 oz. 35 cts., $1 / 4$ lb. $\$ 1.00$.

\section{Golden \\ Carmine Beans}

Extra large beans. New. Try a few. Pkt. $10 \mathrm{cts}$ 1b. 35 cts., 2 lbs. 65 cts.

\section{Sure Crop Wax Beans}

Stringless, rustproof, a good yielder. Pkt. 10 cts.. b. 35 cts., 10 lbs. $\$ 2.50$.

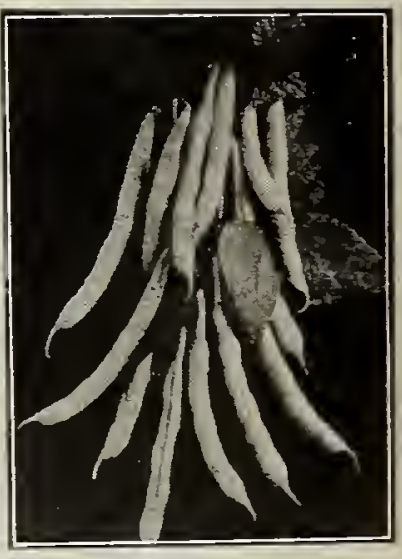

Sure Crop Was Beans.

\section{Martynia}

The seed pods are used for pickling when gathered young and tender. Sow in open ground in May, in hills 3 feet apart each way, or in hotbed, and afterward transplant. If once planted in the garden, voluntary plants are likely to spring up the following year from scattered seeds. Proboscidea. Large size, with long horns. Pkt. 10 c., oz. 25 c., $1 / 4$ lb. 90 cte., lb. $\$ 3.25$. 


\section{Edwards' New Perfecto Cantaloupe}

Nearly round and densely covered with a hard gray netting; flesh very thick and of a beautiful salmon color. shading into green as it nears the rind. Pkt. 10 tts., oz. $20 \mathrm{cts} ., 1 / 4 \mathrm{lb}$. 50 cts., lb. $\$ 1.25$ postpaid.

\section{Tip Top Muskmelon}

Nearly round, deeply ribbed, moderately netted; flesh is bright salmon. thick and of good flavor. Pkt. 10 cts., oz. 15 cts., 2 oz. 25 cts., $1 / 1$ lb. 35 cts., 1 lb. $\$ 1.25$, parcel post paid.

\section{Shumway's}

\section{Giant Muskmelon}

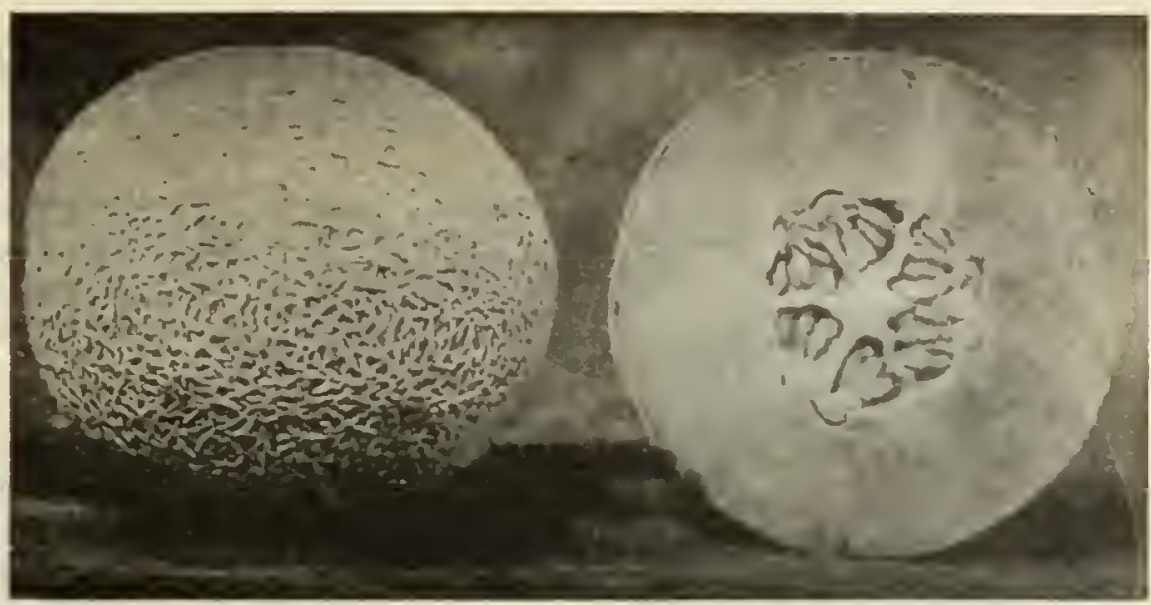

Salmon flesh, extremely large, almost round, no netting, and yellow when mature. Pkt. 10 cts., 1 oz. 20 cts. $1 / 4$ lb. 50 cts., 1 lb. $\$ 2.25$.

\section{Pollock Muskmelon}

The original pink meated Rocky Ford. Pkt. $10 \mathrm{cts}$. oz. 20 cts., $1 / 4$ lb. 60 cts., lb. $\$ 1.75$.

\section{Edible-Podded Sugar Peas}

Used in the same manner as wax beans

Glant Lusclous Sugar (Salad Peas). Without an equal for sweetness and tenderness. Eaten either shelled or in the pod. This is the best of the edible varieties. May be sliced. boiled and served with butter and sauce. Pkt. 10 cts.. lb. 35 cts., 2 lbs. 60 cts.. postpaid. By express or freight, 5 lbs. $\$ 1.25,10$ lbs. $\$ 2.00$

\section{English Peas}

Market Surprise Peas. Will produce excellent peas of the finest flavor in 60 days. 1 lb. 35 cts., 2 lbs. 60 cts.. postpaid. 'Not prepaid, $\$ 3.00$ per peck.

\section{Squash, Banana}

This squash grows from one to two fect in length. The skin varies from a bright yellow to a dark olive green. Flesh, firm and solid, of beautiful orange-jellow and excellent quality. When quite young it is excellent to cook as a marrow. Pkt. $10 \mathrm{cts} ., 02.25 \mathrm{cts} .01 / 4 \mathrm{lb} .85 \mathrm{cts.}, \mathrm{bb}$. $\$ 2.50$. postpaid.

\section{Squash}

Delieata. A small squash for botll summer and winter use. Golden color mottled green. Pkt. 10 cts., 0z. 25 cts. $1 / 1 \mathrm{lb}, 75 \mathrm{cts}$.

Cocozelle. A wonderful new squash. 12 to 16 inclies long. Try a few this year. Pkt. $10 \mathrm{cts.,} \mathrm{0z.} 25 \mathrm{ctg.,}$ $1 / 4$ tb. $75 \mathrm{cts}$
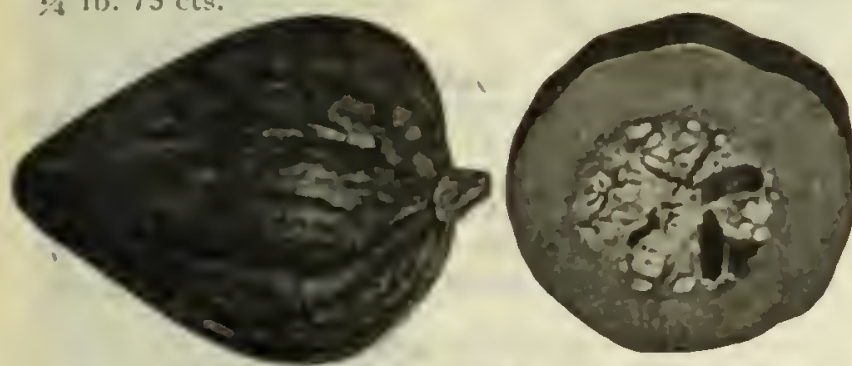

Delicata Squash.

\section{Radish, Johnson's Perfection}

The best of the Red Turnip white tipped varietles. Market Gardeners will find ready sale for this brilliant scarlet whlte-tlpped variety. Pkt. $10 \mathrm{cts..} 0 \mathrm{z} .20 \mathrm{cts..} 1 / \mathrm{l} \mathrm{lb} .50 \mathrm{cts.}$ Ib. $\$ 1.25$, post pald.

\section{Anaheim Chili Pepper}

Anaheim Chili is degired above all others for culinary use because of its agrecable pungcncy. That is what makes it the best seller in the market and the best pungent variety for canning. l'kt. $10 \mathrm{cts.0} 0 \mathrm{z} .50 \mathrm{cts.}, 1 / \mathrm{lb}$. \$1.50, Ib. S4.75, postpaid.

\section{Golden Honey Watermelon}

Oblong, white seed, yellow flesh melon, dark green wlth indistinct stripes, a very fine variety. Plet. $10 \mathrm{cto.} 0$. $15 \mathrm{cts} ., 1 / \mathrm{s}$ Ib. $35 \mathrm{cts} ., \mathrm{lb} . \$ 1.25$.

\section{King and Queen Winter Watermelon}

It ls Russian in origin; round in shape, about the slze of the Honey Dew muskmelon; the skin is a light cream in color with very faint irregular stripes of light green. It is very early, prolific and its edible qualities are excellent. The seed are quite small and very black. Average weight, 10 pouncls. Pkt. $10 \mathrm{cts}$., if $1 \mathrm{~b} .50 \mathrm{cts} ., 1 \mathrm{lb} . \$ 1.50$.

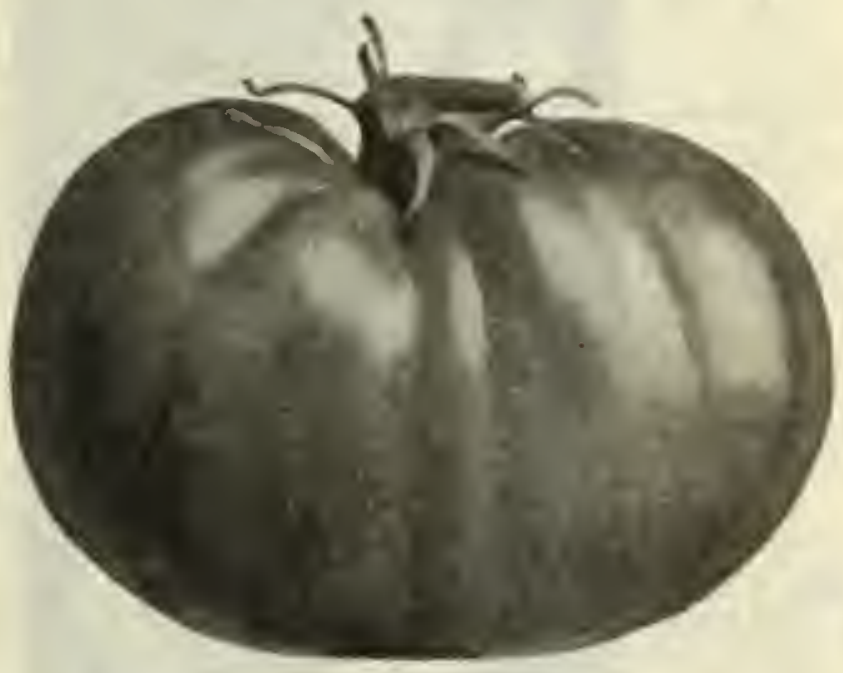

Colossal Tomato.

\section{Tomato, First Early}

Best for the early market. For a first early money-maker it has no equal in the tomato line. P'kt. $10 \mathrm{cts..} 02.50$ cts.. '\$ lb. \$1.75. Ib. \$5.00. postpaid.

\section{Tomato, Gulf State Market}

The best of the early, purple-fruited varictieg. Globeshaped. very solid, free from cracking and productive. l'kt. 10 cts., oz. $50 \mathrm{cts.0} \mathrm{!+} \mathrm{lb.} \$ 1.75,1 \mathrm{~b} . \$ 5.00$, post paid.

\section{Colossal Tomato}

The largest of all. The finest quallty. Often attalns a weight of 18 ozs. to 2 bs. Pkt. $10 \mathrm{cts.}, 1 / 6$ oz. $35 \mathrm{cts}$. 1/2 oz. 60 cts.. oz. \$1.00.

\section{SPECIAL OFFER}

Any $81 \times 10$-cent packares. Any twelve 10 .cent prekages.........
Do not tall to include $80 m$ seed isted on 5.50 pages 2,3 and 4 . 


\section{New and Selected Flower Varieties}

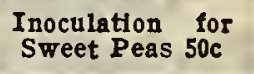

\section{COSMOS}

Anemone Flowered or Crown and Crested. These differ from the other cosmos in the formation of the center of the flower, which develops a crown or crest.

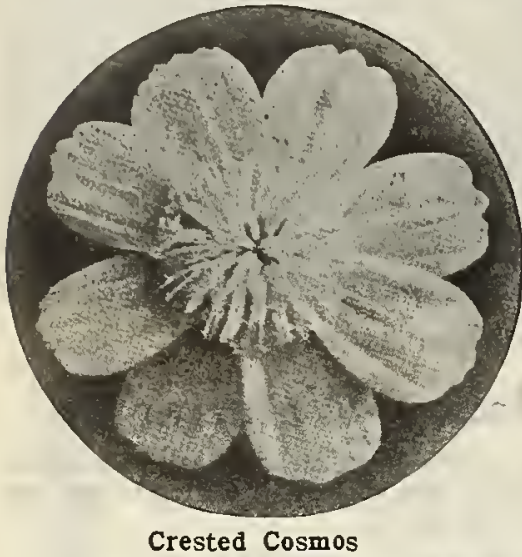

like a n a n emone, the guard pe $t$ a ls remain the same.

Anemone. Flowe r e d. P i n k Beauty. Pkt. 15 cts.

Anemone. Flower ed. Whit e Queen. Pkt. 15 cts.

Klondyke. Wonderful Golden. Pkt. $15 \mathrm{cts}$.

Anemone. Flowe red. $M$ ixed. Pkt. 15 cts., 2 pkts. 25 cts.

\section{WYATT'S GIANT ANTIRRHINUM (Snapdragon)}

Blooms profusely and continuously during the early spring and summer; very showy in beds, and valuable for cutting. We offer greatly improved varieties, producing long stems and large flowers.

Rose d'Or. $s$ a $1 \mathrm{~m}$ on rose, shadgold. Pkt. 15 cts.

w h i t e Que en. Pure white. Pkt. 15 cts. $1 / 4$ oz. 75 cts.

Brilliant Red. Pkt. 15 cts., $1 / 4$ oz. 75 cts.

Cot $t$ a e Maid. Coral $\mathrm{p} \mathrm{in} \mathrm{k}$. Pkt. 15 cts. $1 / 4$ oz. 75 cts.

G $01 d$ e $\mathbf{n}$ Que en. Large; rich yellow. Pkt. 15 cts. $1 / 4$ oz. 75 cts.

Giant Mixed Pkt. $10 \mathrm{cts}$. $1 / 4$ oz. 30 cts.

\section{AL YSSUM}

Saxatile Compactum (Gold Dust). prettyAlyssum $f$ o $~$ rock - gar$\mathrm{d}$ e $\mathrm{n} \mathrm{s}$ and

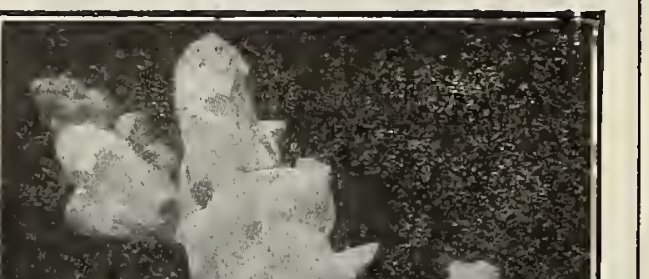

for borders in perennial beds. The plants are 9 inches in height, and spread freely, and produce masses of bright yellow flowers in early spring, which serve to brighten up the beds until the later-blooming perennials come on. Pkt. 10 cts., $1 / 4$ oz. 25 cts., 1 oz. 85 cts.
DIDISCUS (Blue Lace Flower)

Pale lavender blossoms, exquisite. Pkt. 15 cts.

\section{CAND YTUFT (Iberus)}

Perennial Candytufts are excellent for rockwork and the edges of herbaceous borders. The foliage is evergreen and very pretty. The flowers appear in clusters in early spring and are very fragrant.

Gibraltarica. Large delicate lilac flowers blooming in May and June. $1 \mathrm{ft}$. Pkt. 20 cts.

Sempervirens. Pure white; blooms in April and May. 10 in. Pkt. 25 cts. Plants $\$ 2.25$ per doz.

\section{VIOLA CORNUTA (Tufted Pansies)}

A cross between violets and pansies, with flowers of large size, strongly perfumed. Almost as large as the pansy, and borne on longer stems. They are excellent for edging.

Mixed Colors. Pkt. $15 \mathrm{cts} ., 1 / 4 \mathrm{oz} .50 \mathrm{cts}$.

\section{MIXTURE OF DOUBLE PETUNIAS}

This is a mixture of the best large flowering and fringed double petunias. Seed is saved from plants grown in pots, carefully pollenized and will produce grand flowers. O course, every one knows only a certain percentage of double flowers may be expected from seed. but our mixture will produce from 20 to 30 per cent of doubles, while the remainder will be choice large single flowers. The weaker seedlings should be carefully saved, as those invariably produce the finest double flowers. Pkt., 200 seeds, 30 cts.

\section{OENOTHERA}

(Evening Primrose)

Excellent for exposed sunny positions. Pkt. 10 cts., $1 / 4$ oz. 45 cts.

\section{LATHYRUS}

(Everlasting or Hardy Sweet Peas)

Mixed Colors. 10 cts. pkt., 1 oz. 60 cts.

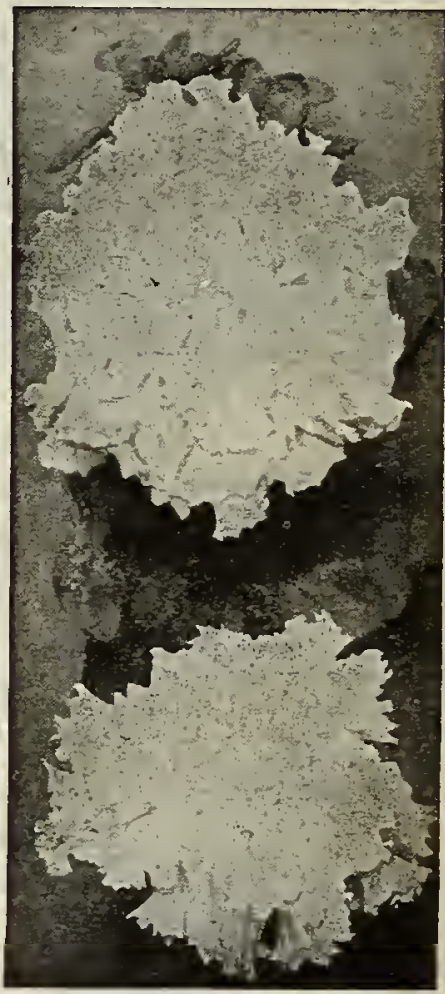

Double Petunias.

\section{LANTANA}

Verbena-like flowers. Good for cutting. Pkt. 10 cts. 1. $1 / 4$ oz. 30 cts., 1 oz. $\$ 1.10$.

\section{ACROLINIUM}

A pretty "Everlasting."

Mixed Colors. Pkt. $10 \mathrm{cts}$., $1 / 4$ oz. $25 \mathrm{cts}$., $1 \mathrm{oz} .85 \mathrm{cts}$.

\section{COBAEA SCANDENS}

A rapid climber; also known as Cup and Saucer Vine. Pkt. 10 cts., $1 / 4$ oz. 25 cts., 1 oz. 85 cts.

\section{PHLOX (Perennial)}

Mixed Colors. Pkt. 15 cts., 2 pkts. 25 cts.

\section{NEW FLOWERS FROM CALIFORNIA}

Golden California Poppy. Pkt. $10 \mathrm{cts.,} \mathrm{oz.} 40$ cts Dahlia. Cactus-flowering. Pkt. $15 \mathrm{cts} ., 1 / 4 \mathrm{oz} .50 \mathrm{cts}$.

Dahlia. Peony-flowering. Pkt. $15 \mathrm{cts} ., 1 / 4 \mathrm{oz} .50 \mathrm{cts}$. 


\section{Wyatt's Dependable Vegetable Seeds}

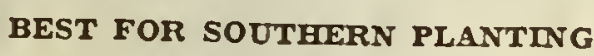

We will send one large packet ol ten different reg. etables for 50 cents, postpaid.

\section{INOCULATE THIS SEED WITH} FARMOGERM

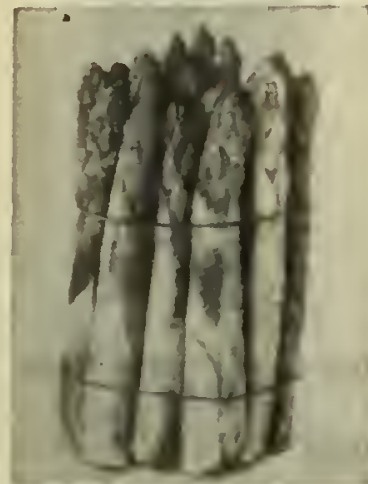

Palmetto Asparagus.
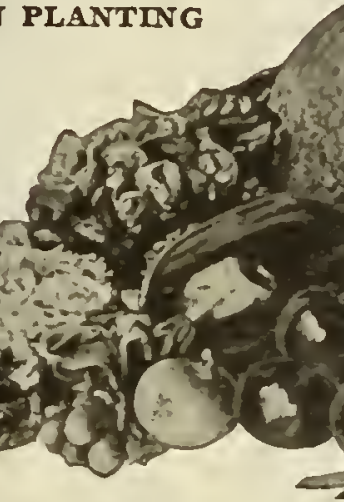

ASPARAGUS

Sow in March or Aprll, in rows 1 toot apart. When two years old, transplant Into perma. nent beds, which shonld he well and deeply manured and trenched to the depth of 2 feet. Set the plant (In rows) from 3 to 4 feet apart and 2 feet in the rows, spreading ont the roots and covering 6 to 8 inches. On the approach of winter, cover with manure, or compost; fork the heds early in the spring and apply a dressing of salt. Cut for nse the second year after planting in permanent bed.

Palmetto. This is the favorite and earliest variety grown in the Sunth. 1'kt. $10 \mathrm{cts}$. 1 oz. $20 \mathrm{cts} .1 / 4$ lb. 40 cts. 11 b. $\$ 1.00$.

Asparagus Roots. $\$ 1.50$ per $100, \$ 12.00$ per 1,000 , f, o. b. Raleigh

\section{ARTICHOKES}

Jerusalem. Used for table and stock feeding. $30 \mathrm{cts}$. per qt.. peck. $\$ 1.50 ; \$ 5.00$ per bu.

BEANS, Bush or Snap $\begin{gathered}\text { One pound will plans } 60 \text { feet of row: } \\ 100 \text { pounds will plane an acre }\end{gathered}$

For the earllest crop, plant just as soon as the weather gets warm-in this section, ahout Aprli 1. To have a snccession plant eree two theeks throughout the summer nnill the middie of Angust, or, farther south, as lato as September 20 . For Geld cnlture, plant in rows $2 \%$ to 3 feet apart, 3 inches between the Beans, covering ahont 2 inches. In small gardens the rows may he only 2 feet apart. Cultivalo often natil they blossom, not afterward, and never when the Fines are wet. To prevent anthracnose, blight, mildew, rust and leaf. spot, spray early and frequently with Bordeaux Mixture. Will mature in 12 to 70 days.

\section{Green Podded Varieties}

Wyett's Improved Red Valentine. Pods 416 inches long, round and crease-backed, medium green, brittle even when full grown. By frelght or express or huyer paylng postage. 5 lbs. \$1.25. 10 lbs. \$2.00. 100 lbs. $\$ 18.00$.

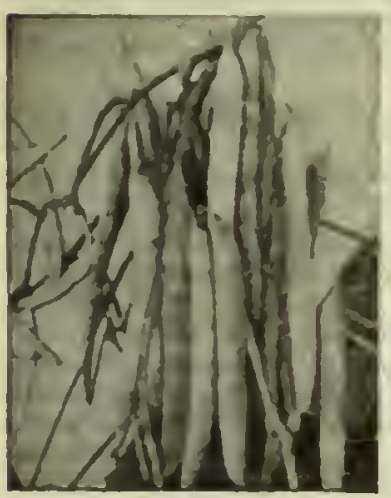

Bouatiral

Black Valentlne. Very hardy and productive; the green pods are fit for the table In 45 days. 5 ibs.. $\$ 1.50,10$ lbs. $\$ 2.25,100$ ibs. $\$ 20$. Not prepaid. 500 lbs. at $16 \mathrm{cts}$.

Bountiful. The pods are from 5 to 6 inches long. large and flat. The seel is of medium size and of a solid. rich yellow color. 5 lhs. $\$ 1.25,10 \mathrm{lbs} . \$ 2.00,100 \mathrm{lbs}$. $\$ 19.00$. Not prepaid.

Burpee's Stringless. Early, hardy. vigorous, productive. Pods large. 5 in. long. stout, round and crease-backed; dark green in color. strictly stringless. tender and brittle; of good quality. 5 lbs. $\$ 1.50,10$ lbs. $\$ 2.50,100$ lbs. $\$ 20$. Not prepaid.

1,000-to-1, or Extra Early Refugec. Enormously prolific, and from Its carliness is almost.certain to produce a crop in any' kind of season. By freight or express or buyer paying postage. 5 lbs. $\$ 1.25,10$ lbs. $\$ 2.00,100$ lbs. $\$ 19.00$.

All varietics postpaid prices, as follows: Pkt. $10 \mathrm{cts.,} \mathrm{1/4} \mathrm{It.}$ $15 \mathrm{cts}, 1 / 2$ lb. $25 \mathrm{cts}$., Ib. $35 \mathrm{cts.}, 2 \mathrm{lbs} .65 \mathrm{cts}$, except as noted. IRemenuber, these are Prepaid P'rices.

Longtellow, or French Stringless. A round, solid. very early. green-podded Bean. Good quality. very tender and crisp, and exceedingly prolific. 5 Ibs. $\$ 1.50,10$ lbs. $\$ 2.25,100$ lbs. $\$ 20.00$. Not prepaid.

Glant Stringless. Somewhat slmilar to Burpec's Stringless, buc vod is a little longer, stralghter and more slender; more depressed between Beans and slightly llgliter in color; early, hardy. and of hlghest quality. 5 lbs. $\$ 1.50,10$ lbs. $\$ 2.50,100$ Ibs. $\$ 20.00$. Not prepaid.

Full Measure. A new main crop variety of bush bean-a stringless Round Green Pod Bean. Pkt. 10 cts.. lb. 35 cts. 2 lbs. 65 ct8.. 10 lbs. $\$ 2.50$, postpaid.

Early Round Pod Six Weeks. Early sort for market. Good yielder. Pkt. 10 cts., 1b. 35 cto., 2 lbs. 60 cts.. 10 lbs. $\$ 2.50$.

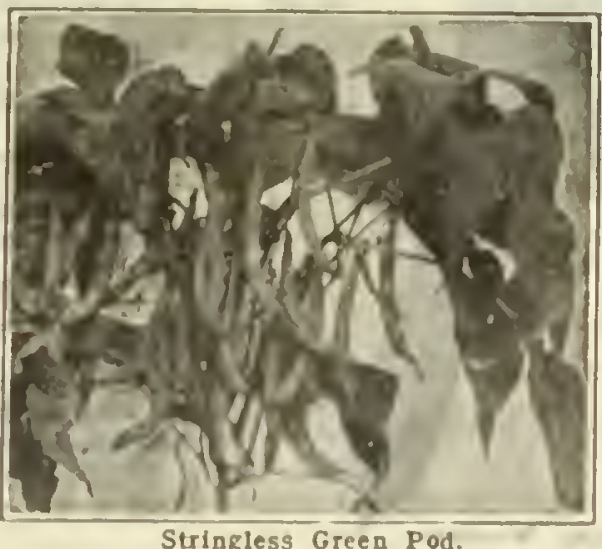




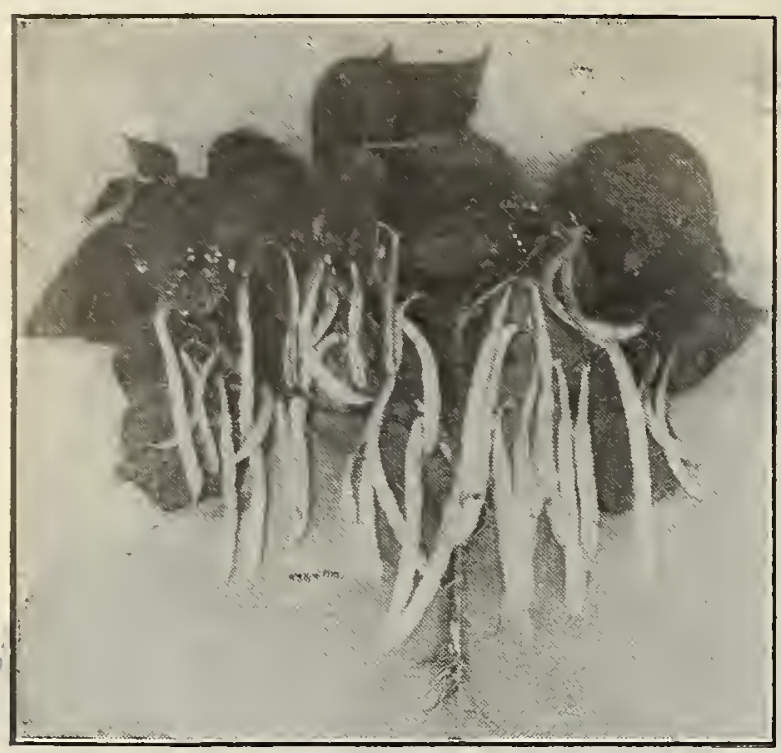

Improved Golden War

\section{Yellow, or Wax- Podded Bush Beans}

Currie's Golden Wax. Early, hardy, nearly rust-proof. Long, golden-yellow pods, crisp and tender. The seed is black. The much-planted sort. Pkt. 10 cts., lb. 35 cts., 2 lbs. 60 cts., 10 lbs. $\$ 2.50$, postpaid.

Prolific Black Wax. Very early; prolific; long pod. Pkt. 10 cts., lb. 35 cts., 2 lbs. 60 cts., 10 lbs. $\$ 2.25$, post paid. By express or freight, $10 \mathrm{lbs}$. $\$ 2.00,100$ lbs. $\$ 16.75$.

Pencil Pod Black Wax. Bushy vines, very prolific, 15 inches high, bear round, thick, stringless, rich yellow pods, 6 to 7 inches long. Pkt. 10 cts., lb. 35 cts., 2 lbs. 60 cts., 10 lbs. $\$ 2.25$, prepaid. Not prepaid, $1 / 2 \mathrm{pk} . \$ 1,75, \mathrm{pk} . \$ 3.00$

Improved Golden Wax. Probably the most popular of the wax varieties and one of the best. Early and productive, pods 5 inches long, very stout, straight or slightly curved, and oval in form; flesh brittle, stringless and of good quality; color bright yellow; seed white, much mottled brown. Pkt. $10 \mathrm{cts}$., lb. 35 cts., 2 lbs. 65 cts., postpaid. Not prepaid, $1 / 2$ pk. $\$ 1.75$,pk $\$ 3.00$. 1 bus., 60 lbs. $\$ 10.80$

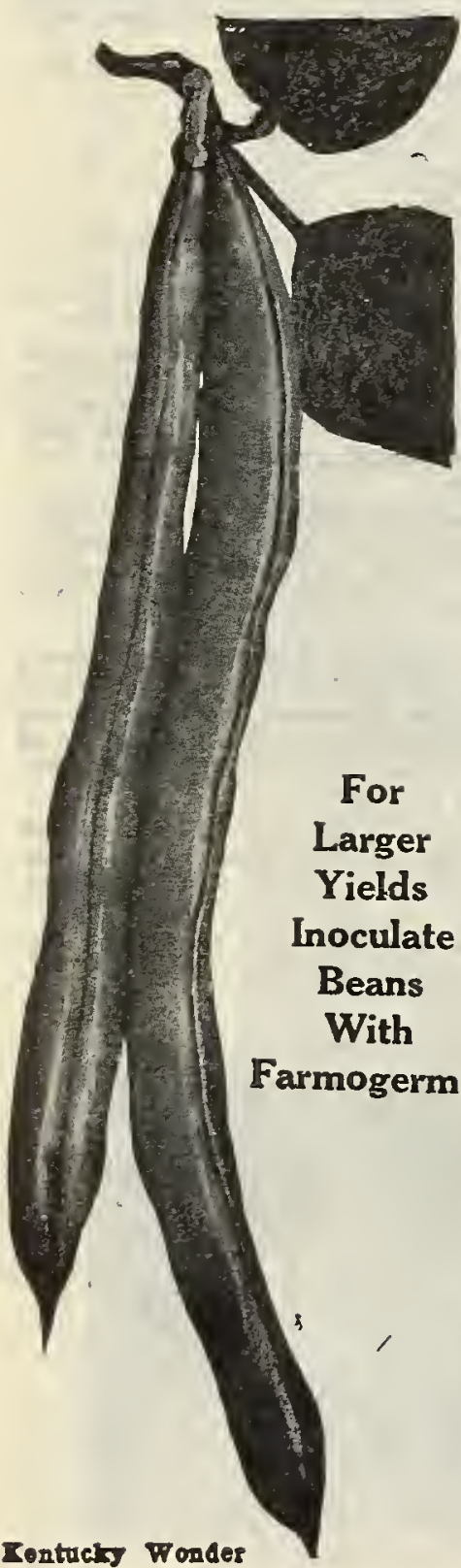

Cabbage, or Crystal White Wax. A very beautiful. distinct, and desirable variety, producing pods of good size. Color waxy white and almost transparent; stringless, crisp, tender and of rich flavor. The pods develop quickly, but mature slowly and remain in condition for table use longer than any other variety. Pkt. 10 cts., lb. 35 cts., 2 lbs. 65 cts., postpaid; by freight or express, 10 lbs. $\$ 2.50,100 \mathrm{lbs} . \$ 22$.

\section{Pole, or Cornfield Bean}

These are much stronger growers than Bush Beans and require good, strong stakes. They give a much greater yield than Bush Beans, but being more tender, should never be planted before May in this section.

Use poles about 8 feet long and set firmly 4 feet apart each way. Plant five to elght Beans in a hill, $1 \frac{1 / 2}{2}$ to 2 inches deep. When well started, thin to four plants in $a$ hill. They are sometimes planted in the hills of field corn.

Old Homestead, or Kentucky Wonder. The most popular green-podded climbing or corn-hill bean; early and productive. Pods 8 to 9 inches long; very slender decidedly curved; slightly stringy, tender and good quality. Pkt. 10 cts., lb. 35 cts. 2 lbs. 60 cts., postpaid. Not prepaid, 30 cts. lb., 5 lbs. $\$ 1.25,1$ pk. $\$ 3.00$.

White Kentucky Wonder. A very early, white-seeded variety. Pods 6 to 7 inches long, round, slender and straight; very tender, fleshy and stringless; of high quality color dark green. Pkt. $10 \mathrm{cts}$., lb. 35 cts., 2 lbs. 65 cts., postpaid. 1 pk. $\$ 3.00$.

Striped Creaseback Scotia, or Nancy Davis. Plants large, compact; vigorous grower; pods about 7 inches long, almost straight or slightly bent backward at the end, round, well filled, and of good quality. Pkt. $10 \mathrm{cts.,} \mathrm{lb.} 35$ cts., postpaid; by freight or express, 10 lbs. $\$ 2.40,100$ lbs. $\$ 21.50$.

Lazy Wife. Good shell beans; long, thick, stringless pods. Crop very short. Pkt. 10 cts., lb. 35 cts.r 2 lbs. 65 cts., 10 lbs. $\$ 2.75$, postpaid.

Scarlet Runner. Ornamental, bright red flowers. Good snap bean. Pkt. 10 cts. 1b. 35 cts., 2 lbs. 65 cts., 10 lbs. $\$ 3.00$, postpaid.

Cut Short, or Cornfield. Very popular throughout the South for planting in corn. Pods fleshy and of good quality. A good yielder and well liked wherever grown. By mail, postpaid, pkt. 10 cts., lb. 35 cts., 2 lbs.. 65 cts., 5 lbs. $\$ 1.35,10$ lbs. $\$ 2.25$. By express, lb. 30 cts., 2 lbs. 50 cts., 5 lbs. $\$ 1.20,10$ lbs. $\$ 2.25,100$ lbs. $\$ 17.50$.

Kentucky Wonder Wax. It is similar in habit of growth to "Kentucky Wonder Green Pod," and bears as early, or when about as high as the average bush bean. Pods are beautiful golden-yellow, and so fleshy that often the thickness surpasses the width; make delicious eating. Pkt. $10 \mathrm{cts.,} \mathrm{lb.} 40$ cts., 2 lbs. 70 cts., $10 \mathrm{lbs}$. $\$ 2.75$, postpaid. Not prepaid, 30 cts. lb.

Striped Creaseback Scotia, or Nancy Davis Pole Beans produced more and better green beans during the severe drought of 1925 than any other sort.

We would call special attention to our lists of Farm Seeds, including Grasses, Clovers, Alfalfa, Wheat, Oats, etc., which will be found fur: ther on in this catalogue. These are all of the very highest quality, and we heartily recommend them to our farmer friends.

"The crop difference between an acre of regular Clover and an acre of FARMOGERM Clover will pay for the inoculation of 5 to 10 acres. See page $48 . "$ 


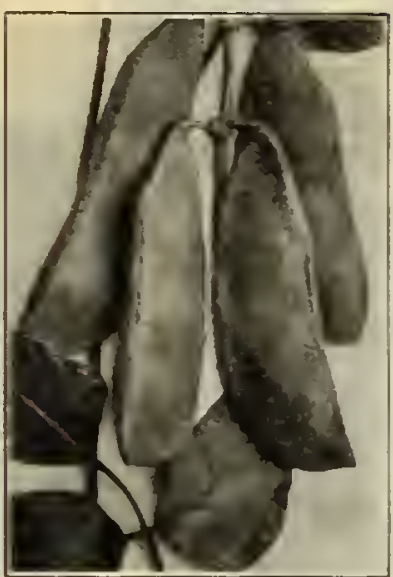

Headersoa'a Bush Cima-Extra Early, Ver Prollic, Best Quallty.

Henderson's Bush Lima. The original well-known small Bush Lima. It is earlier, a larger yielder, and of good flavor. Pkt. $10 \mathrm{cts.,} \mathrm{1b.} 35 \mathrm{cts.} 2$ lbs. $65 \mathrm{cts}$. post paid. Not prepaid, 24 cts. Ib., peck 15 lbs. $\$ 3.50 .100$ lbs. $\$ 22.00$.

\section{Pole Lima Beans}

IVill malure in 70 to 90 days

\section{Bush Lima Beans}

Will malure in 70 to 90 doys

IIma Beans aro sensitive to cold and should not be planted until all danger of frost is past. Require a rich, light, preferably sandy soll, which helps to mature the "Limas" quickly. Select a rich soll or use old, well-rotted manure. Plant in hils $21 / 2$ to $31 / 2$ feet apart each way and 5 to 6 seeds in hill, or in rows 2 to 3 feet apart, 4 to 6 inches between the plants in the row and 2 inches deep. Draw the coll up along the plants, but do not work among the beans when wet, as this induces rust.

Prollfic Bush Lima. A very good, mediumsized Bush Bean, larger than the Henderson Bush and not as large as the Burpee Bush. Pkt. 10 cts.. lb. 35 cts., 2 lbs. 65 cts.. post paid. Not prepaid. $25 \mathrm{cts}$. lb.. 1 pk. $\$ 3.00$.

Burpee's Fordhook Bush Lima. A most excellent variety and exceedingly popular with market-gardeners. Pods about 5 inches long. containing four or five large, ovalshaped, very thick white Beans. Pkt. 10 cts. lb. 40 cts., 2 lbs. $75 \mathrm{cts}$.. postpaid. Not prepaid. $35 \mathrm{cts}$. $1 \mathrm{~b} .$. peck $15 \mathrm{lbs}$. $44.95,100 \mathrm{lbs}$ $\$ 29.00$. 500 lbs. at $27 \mathrm{cts}$.

Burpee's Improved Bush Lima. Of enormous size, eight day's earlier than the old Burpee's Bush Lina, and the Beans are larger and thicker. Pkt. $10 \mathrm{cts}$. lb. $35 \mathrm{cts} .2$ lbs. $65 \mathrm{cts}$. postpaid. By freiglt or express, 10 lbs. $\$ 2.60$ 100 lbs. $\$ 22.00$.

Write for prices on $100 \mathrm{lb}$. lots or larger of any variety.
Fordhook Bush IIma

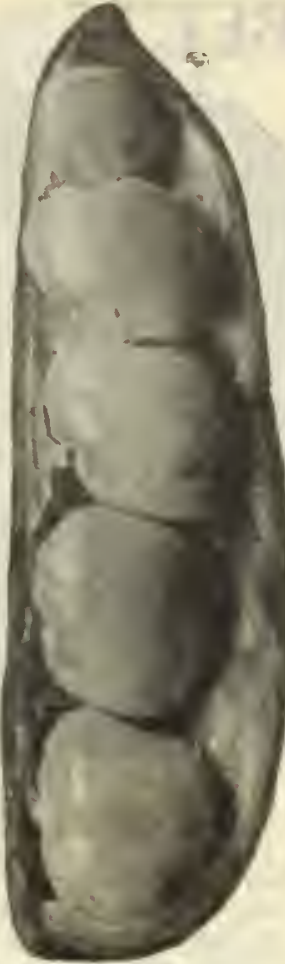

INOCULATE THIS SEED WITH

Wyatt's Improved Pole Lima. Much larger than the small lima and earlier and much more prolific than the large white Lima Beans. Pkt. 10 cts.. lb. 35 cts.. 2 lbs. 65 cts.. postpaid. Not prepaid. $25 \mathrm{cts}$ lb., 1 pk. $\$ 3.00$.

Small White Pole Lima. Also known as "Carolina" or Carolina, or Sieva "Sieva" Bean. A climbing Pole Lima or form of the Henderson Bush Lima and very popular. This variety is a continuous bear. er and furnishes the most tender and delicious Beans for the table. It's very prolific and a hardy grower for "butter beang" in the South. Pkt. $10 \mathrm{cts.}$ 1/ $\mathrm{lb} .20 \mathrm{cts}$. lb. 35 cts., 2 lbs. 65 cts.. post paid. Not prepaid. 15 lbs.

(peck) $\$ 3.50,60$ lbs. (bu. $\$ 13.50,100$ lbs. $\$ 22.00$.

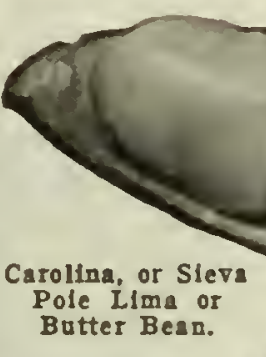

\section{Eat More Beans}

Beans of all Hnds are one of the best and most nutritions forms of food for human beings. They are good both steen and dry. They are easier to krow in the South than any other vegetable. Grow and eat more Beans.

\section{Hammond's Slug Shot \\ KILLS CABBAGE AND CAULIFL OWER WORMS}

1 pound carton with peric. rated top, 35 cts., postpald.

By express or freight, not prepald, 1 pound carton, 25 cts., 5 pound package, $60 \mathrm{cts}$., 10 pound package, $\$ 1.15$.
Brussels Sprouts.

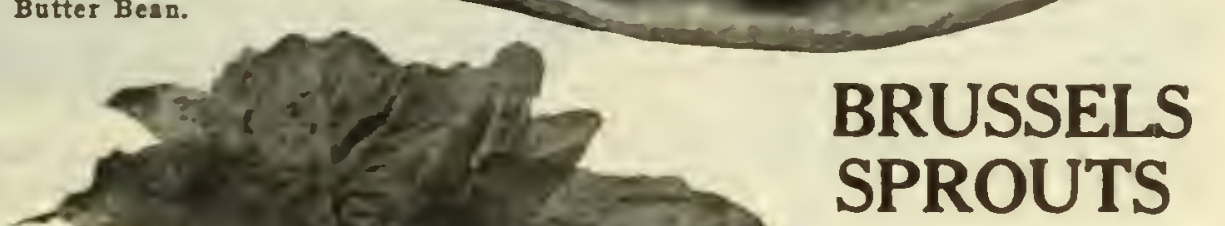

One ounce aill produce about 3,000 plants 


\section{BEETS}

Two ources of seed will sow 100 feet of row; about 7 pounds will sow an acre. Will mature in 40 to 60 days.

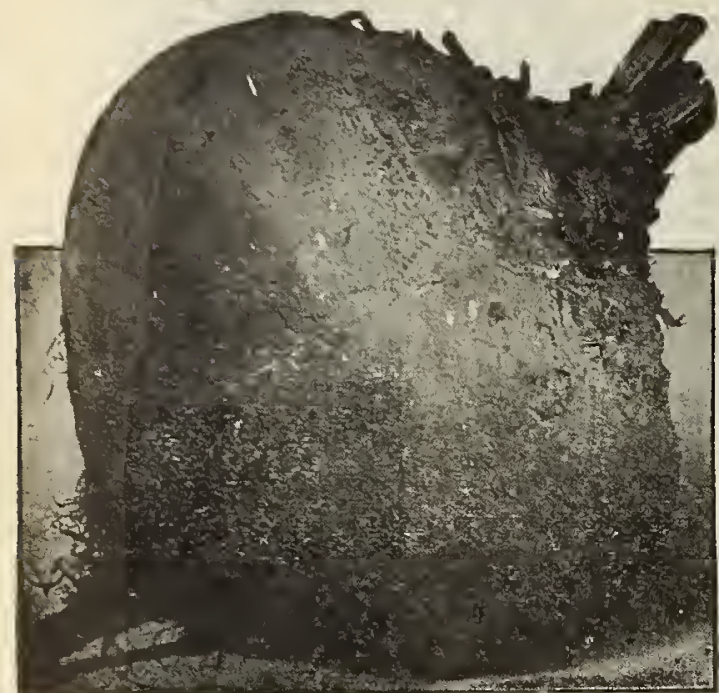

Detroit Dark Red.

For very early crop, the seed should be sown in hotbeds or started in bozes in the house in January and February. Aftor danger of frost is past, $t r$ ans 1 a $\mathrm{nt}$ and set them in rows 2 to 3 feet apart and 6 to 8 inches apart in the rows. Or they can be sown out-side from March to July, as desired for medium, early or late crop, in drills, covering 1 inch, and plants thinned to 6 to 8 inches. Beets should be grown in light, clean, deep soil and kept well

Improved Early Blood Turnip.

The old standard table Beet. Roots nearly round or slightly flattened, bright red, zoned and of good quality. Pkt. 5 cts., oz., 10 cts., $1 / 4$ lb. 35 cts.' lb. $\$ 1.00$, postpaid. 5 lbs."at 85 cts.

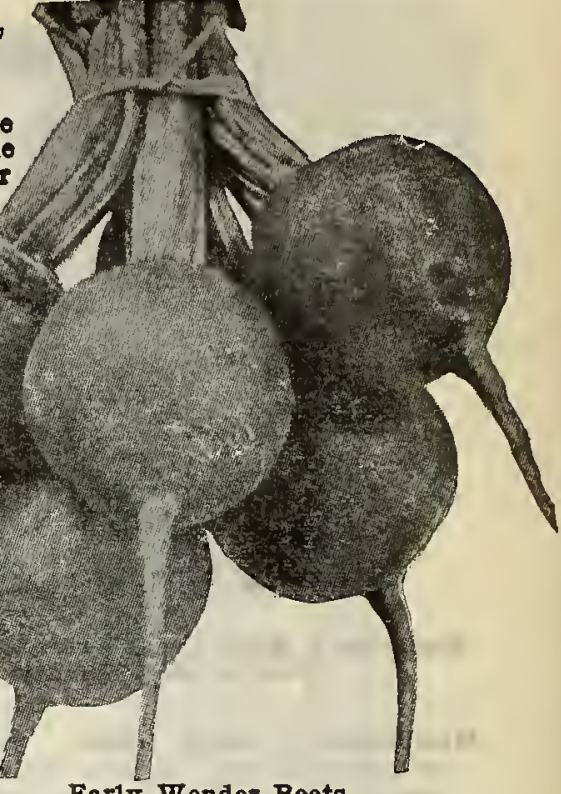

Early Wonder Beets.

Crimson Globe. Early; rich crimson; perfect globe; smooth and clean. Very attractive and a general favorite. Pkt. 5 cts., $1 / 4$ lb. 40 cts., lb. $\$ 1.25$, postpaid; by express, 1 b. $\$ 1.15$.

Detroit Dark Red. Here is a Beet you will like, whether you grow for home use or market. Almost globe-shaped, with small tops and tap-roots, very smooth and of dark blood-red color. The quality is fine and for canning purposes it has no superior. Pkt. 5 cts., oz. $15 \mathrm{cts.,} 1 / 4 \mathrm{lb}$. $40 \mathrm{cts.,} 1 \mathrm{~b} . \$ 1.35$, postpaid; by express, $1 \mathrm{~b}$. $\$ 1.00,5 \mathrm{lbs}$. and over, $90 \mathrm{cts}$. per lb.

Extra-Early Eclipse. An early variety, with small top and medium-sized, round, bright, deep red roots. Flesh bright red, zoned pinkish white. Pkt. 5 cts., oz. 10 cts., $1 / 4$ lb. 35 cts., lb. $\$ 1.00$, postpaid.

Extra-Early Egyptian. One of the very earliest, with small tops; roots flat and moderately thick; very dark red; flesh dark purplish red. Pkt. 5 cts., oz. 10 cts., $1 / 4$ lb. 35 cts., lb. $\$ 1.00$, postpaid. 5 lbs. at 85 cts.

Long Smooth Blood-Red. Roots long, penetrating the soil deeply, but seldom growing more than 2 ins. in diameter. Pkt. 5 cts., oz. 10 cts.. $1 / 4$ lb. 35 cts., lb. $\$ 1.00$, postpaid.

Crosby's Improved Egyptian. Very early strain of the old standard Egyptian; small tops, good shape; popular with the truckers. Pkt. 5 cts., oz. 10 cts., $1 / 4$ lb. 30 cts., lb. $\$ 1.10$. postpaid; by express, $1 \mathrm{~b} .90 \mathrm{cts}$.

Ear l y w o n d e r B e ets. Deep blood-red; nearly globular in shape with a small root and top; one of the earliest and most uniform bunching beets that can be grown. Postpaid, pkt. $10 \mathrm{cts}$., oz. $20 \mathrm{cts}$., $1 / 4$ lb. $45 \mathrm{cts}$., lb. $\$ 1.25$.

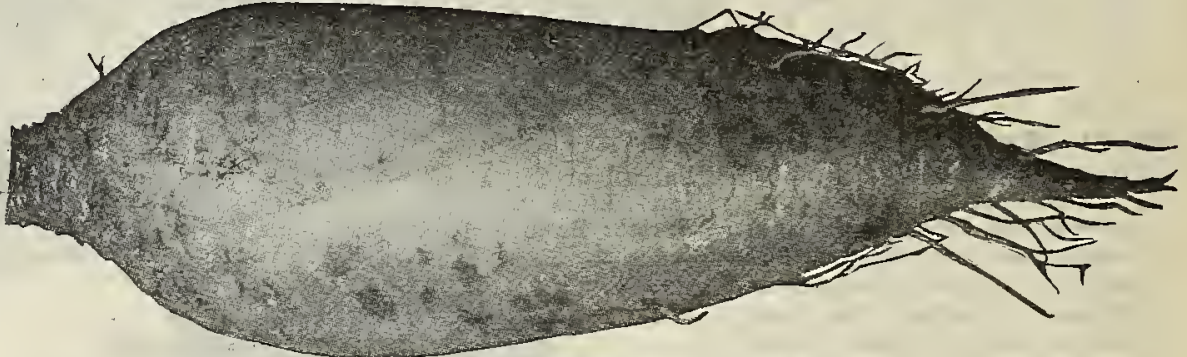

Mammoth Prize Long Red Mangel.

(A good feed for cattle and poultry.)

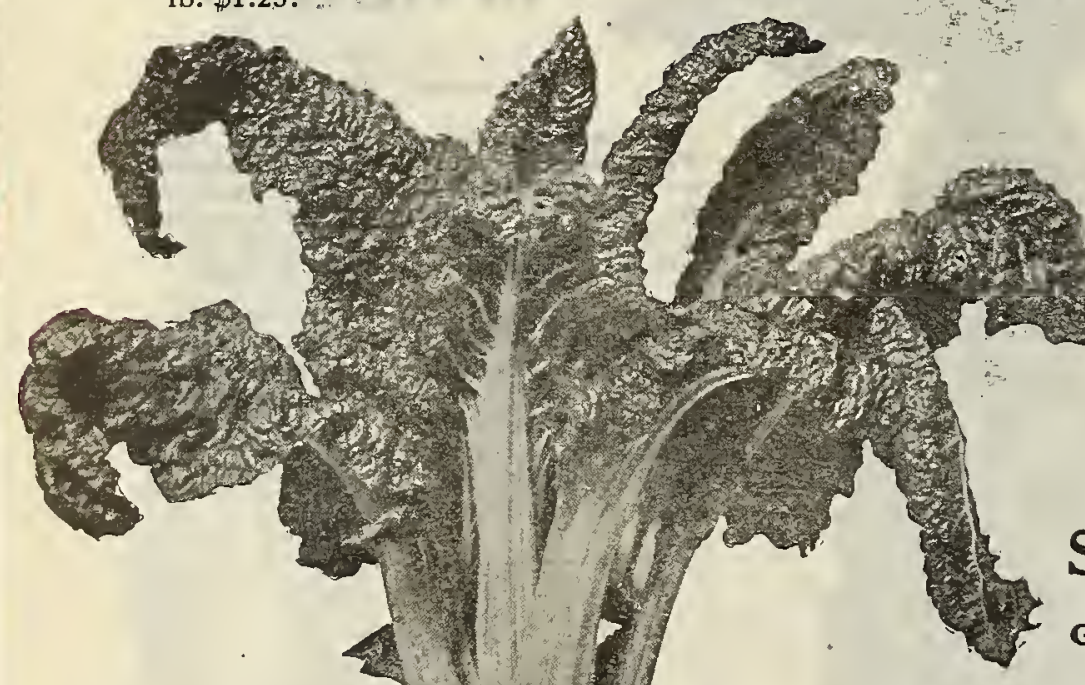

ner as spinach, sometimes, however, the midrib will quickly produce plants from which cuttings may be made in 24 days and continued all summer, as you can cut right down to the ground, and new shoots will soon spring up and make a fast growth, while those plants which are allowed to grow on without any cutting will make large curly leaves, with thick, light-colored midribs, which are delicious when cooked and served like asparagus. Pkt. 10 cts., oz. 15 cts., $1 / 4 \mathrm{lb} .45 \mathrm{cts.}, \mathrm{lb}$. $\$ 1.50$. 


\section{CABBAGE}

One ounce will produce 2,000 plants; 6 ozs. will give enough plants for an acre.

For early spring Cabbage, sow one-quarter of an inch deep from the middle of September to the middle of October and when the plants are large enough, trans. plant. When a supply of plants has not been secured in the fall, sow in coldframes in December, or in a gentle hotbed the last of February. Give plenty of adr at proper times, in order to harden the plants, and transplant in the open ground as soon as the weather permits. For a summer crop, sowings may be made in March until the middle of May. For winter Cabbage, sow Flat Dutch, Drumhead and Savoy from middle of Mar to last of July, transplanting when large enough; late Cabbage shonld be set 3 feet apart and not less than 18 inches in the row. It is useless to attempt the cultivation of this crop without deep and thorough plowing or spading and an abundance of rich, welldecomposed manure or sultable substitutes. Manj successful gardeners grow cabbage withont transplanting. sowing the seed thinly in drills or in hills, and afterward thinning to the proper distance in the row, or to one plant in the hill. Cabbage produces heads in 75 to 130 days.

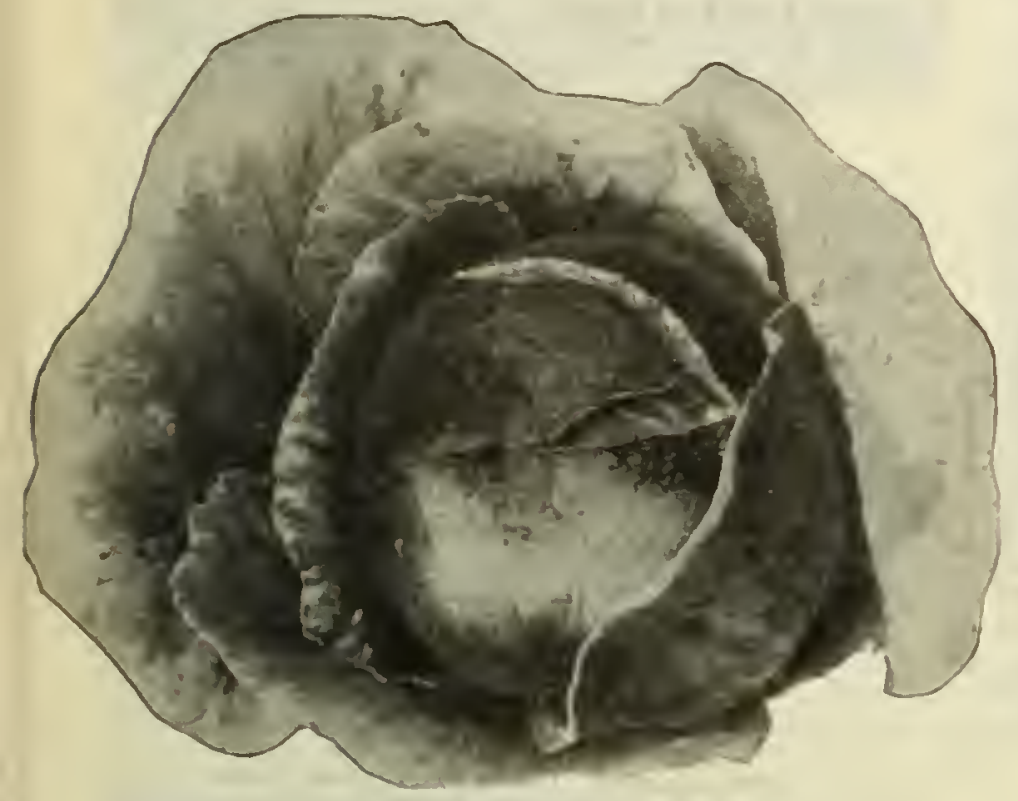

Early Drombead.

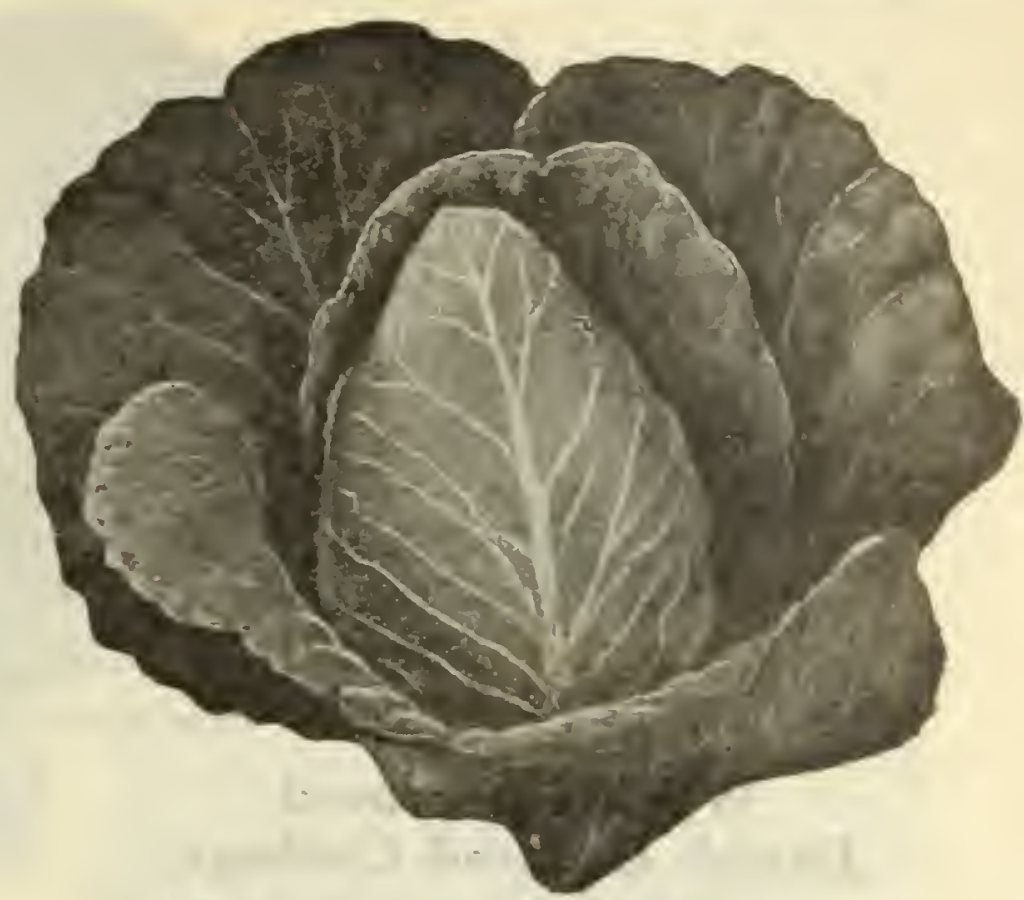

Iarge, or Charleston Wakefield Cabbage.

Early Flat Dutch. Medium early, large, flat, solid heads. A realiable and popular variety, Pkt.10 cts., oz. 25 cts., $1 / 4$ lb. 75 cts.. lb. $\$ 2.35$, postpaid.

Winnigstadt. Medium early, for either early or late use. Heads hard, fine-grained, and cone-shaped. Pkt. $10 \mathrm{cts} ., 0 z .25 \mathrm{cts} .0, \mathrm{lb} .75 \mathrm{cts} ., \mathrm{lb} . \$ 2.40$, post paid.

Glory of Enkuizen (100 days). Large, early, white, solid heads. Pkt. $10 \mathrm{cts.,} \mathrm{0z.} 35 \mathrm{cts.}, 1 / 3 \mathrm{lb} .85 \mathrm{cts}$. lb. $\$ 3.00$.

Volga (115 days). Good size, carly, round, extra quality. Pke. $10 \mathrm{cts} ., 0 z .35 \mathrm{cts} ., 1 / \mathrm{lb} .85 \mathrm{cts}$. lb. $\$ 3.00$.

Perfection Drumhead Savoy. The largest solidheading Savoy: has the rich flavor of the Cauliflower. The plants are strong and vigorous, and withstand the ravages of the cabbage worm better than other sorts. This is the best for market-gardeners, as it will produce larger heads than any other kind of Savoy Cabbage. Pkt. $10 \mathrm{ctg} ., 0 z .25 \mathrm{cts}$., $1 / 4 \mathrm{lb}$. 75 cts., lb. \$2.75, postpaid.

Early Drumbead. A good second early for the home-garden; large. round, very solid head. This wie consider the best for following Charleston Wakefield; it matures about 10 day's later. Pkt. $10 \mathrm{cts}$. oz. $25 \mathrm{cts} ., 1 / 4$ lb. $75 \mathrm{ctg} . .1 \mathrm{lb} . \$ 2.35$ postpaid.

Large, or Charleston Wakefield. About one week later than the Early Jersey Wakefield, but the pointed head is fully one-half larger. Pkt. $10 \mathrm{cts.}$. 0z. $25 \mathrm{cts} .{ }^{\prime}$ lb. $75 \mathrm{cts} ., \mathrm{lb} . \$ 2.40$, nostpaid, 5 lbs. at $\$ 2.25$.

Wyatt's Selected Early Jersey Wakeneld. I.ong recognized as the best early marketable Cabbage. In size, medium: in shape, pyramidal witl pointed peak. Its uncommonly fine headine qualities pleases the most critical gardeners. Our strain of seed is of superior quality. Long Island grown. Pkt, io cts., oz. $25 \mathrm{cts} ., 1 / \mathrm{lb} .75 \mathrm{cts}$. lb. $\$ 2.40$, nost paid.

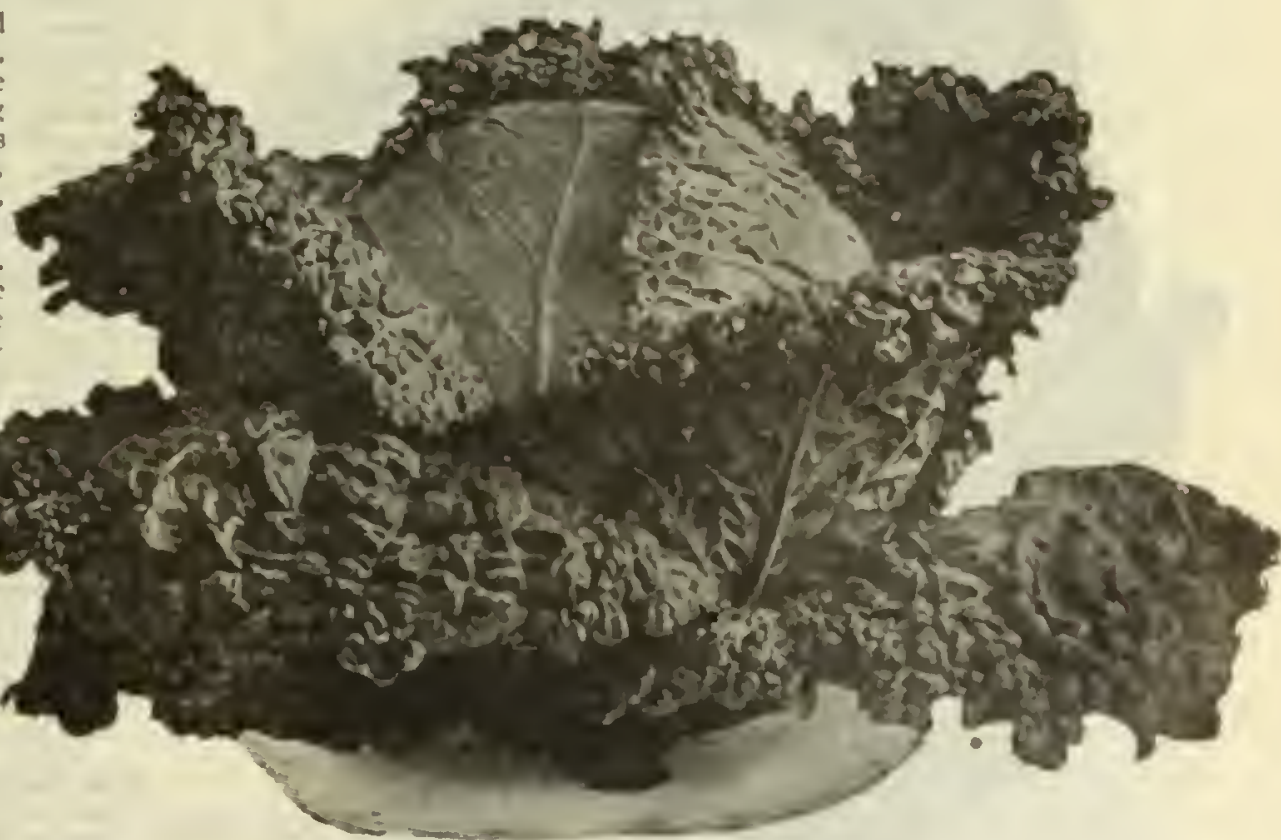

Perfection Drumbed Saros Cabbace.

Cabbage seed by freight or express, except where noted, 5 bs. at $\$ 2.25$ per $1 \mathrm{~b}, 10 \mathrm{lbs}$. at $\$ .15$ per $1 \mathrm{~b} ., 1001 \mathrm{bs}$. at 82.00 per $1 \mathrm{~b}$ 


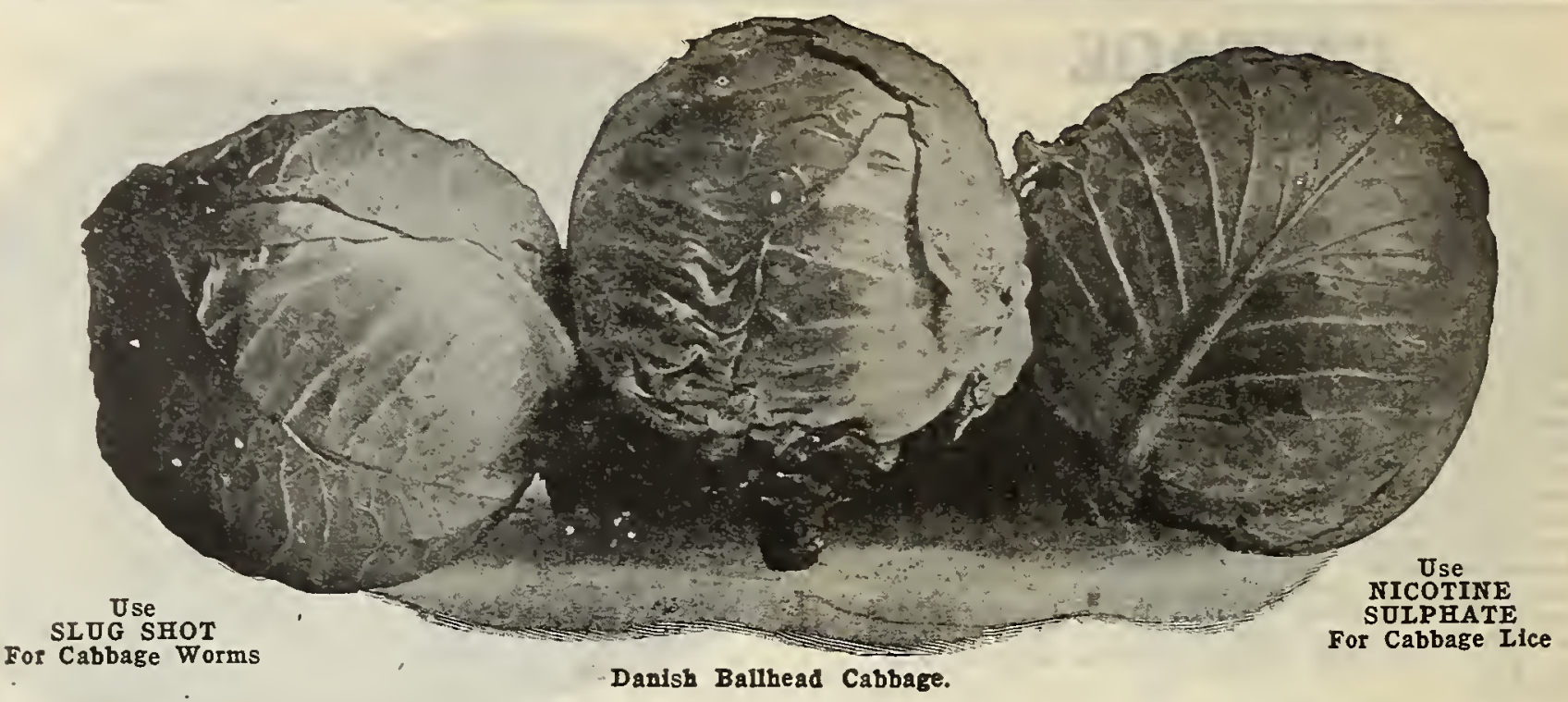

\section{Wyatt's Improved Danish Ballhead Cabbage}

Heads hard, solid, tender and crisp. The leading late sort. Danish Ballhead is more largely grown for market than any other late variety, and without a doubt is the best of the late sorts. It frequently commands a higher price in the market than any other late variety. It is remarkable for the solidity of its heads and long-keeping qualities. The heads are of medium size, measuring from eight to ten inches in diameter, with few outer leaves, admitting of close planting; exceedingly fine-grained, hardiest of all, tender, crisp, solid, with no waste heart. Under fair conditions will average six pounds per head. Pkt. 10 cts.. $1 / 2$ oz. 25 cts., oz. 40 cts., $1 / 4$ lb. $\$ 1.25$, lb. $\$ 3.50,5$ lbs. $\$ 15.00$.

New Copenhagen Market. Undoubtedly the best Cabbage for all conditions. Good for market-growing and home-garden. Heads medium sized, firm, and ro und. 2 P kt. 10 cts., oz. 25 cts., $1 / 4$ lb. 90 cts., lb. $\$ 3.00$.

Henderson's Succession. Is about 10 days later than Early Summer. Is a dwarf, flat head, light green, and very solid. Pkt. 10 cts., oz. 25 cts., $1 / 4$ lb. 75 cts., 1b. $\$ 2.25$, postpaid.

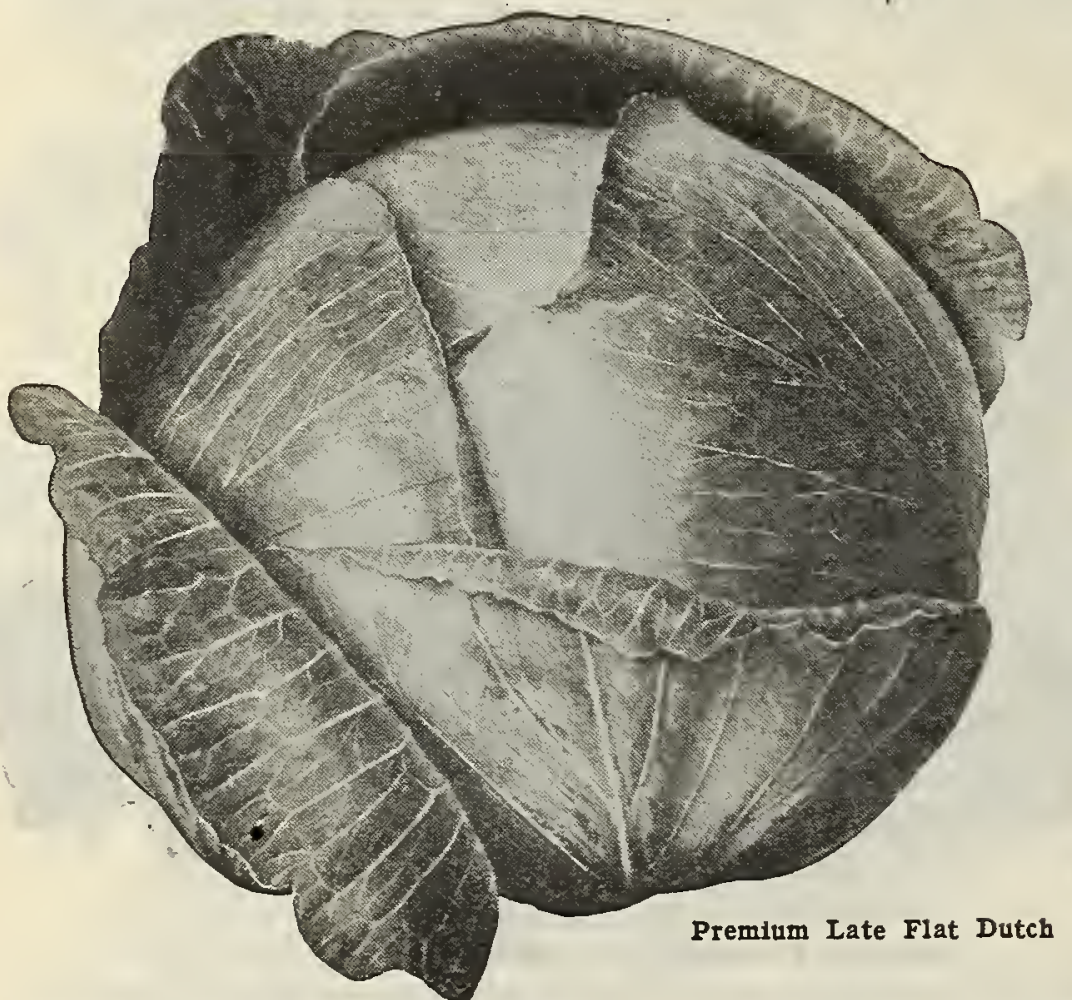

Premium Late Flat Dutch. A popular winter CabbageLarge, solid, flat heads. Pkt. 10 cts., 02.25 cts., $1 / 4$ lb. 65 cts., lb. $\$ 2.35$, postpaid.

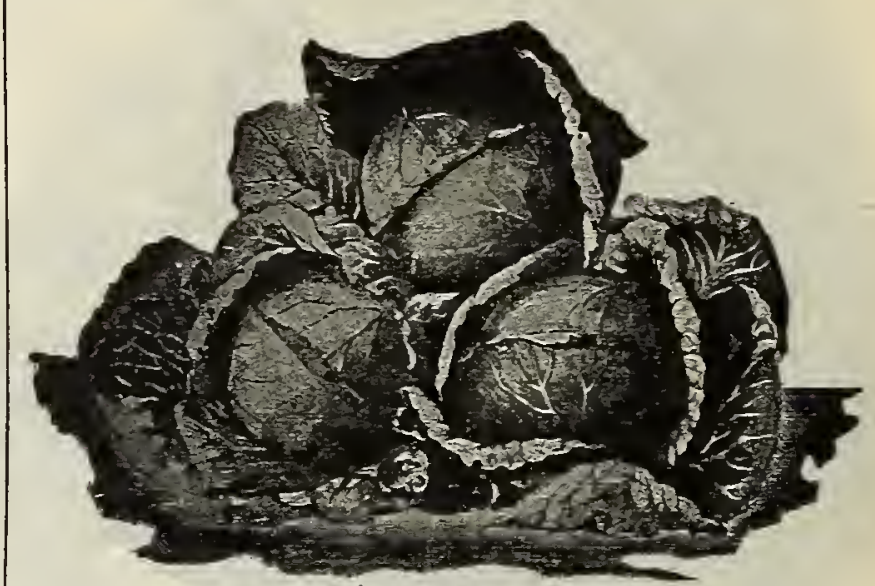

AIl Seasons.

All Seasons-Good Early and Late. One of the finest for second early or late, growing to a large size quickly and surely. The heads are extremely hard, solid, round, flattened at top. It is called "All Seasons" because it is good for autumn as well as early summer. Even under adverse conditions it is a sure header, and though planted late, it keeps well. Desirable for kraut. Ready for market in 110 days. Pkt. 10 cts., oz. 25 cts., $1 / 4$ lb. 75 cts., lb. $\$ 2.25$, postpaid.

Henderson's Early Summer. A desirable, medium-sized, early, flat headed variety. A good keeper and does well in summer and autumn. Pkt. 10 cts., oz. 25 cts., $1 / 4 \mathrm{lb}$. 75 cts., lb. $\$ 2.25$, postpaid.

Autumn King, or World Beater. Heads large, solid, good quality, and keeps well. Pkt. 10 cts., oz. 25 cts., $1 / 4$ lb. 75 cts., lb $\$ 2.25$, postpaid.

Large Late Drumhead. Heads are solid and have few loose leaves, thus allowing of planting closely in the field and thereby increasing the number of heads produced. Pkt. 10 cts., oz. 25 cts., $1 / 4$ lb. 75 cts., lb. $\$ 2.25$, postpaid.

Red Rock. The largest and surest heading red winter Cabbage, and the sort most generally planted by gardeners. Pkt. 10 cts., oz. 25 cts., $1 / 4$ lb. 75 cts., lb. $\$ 2.50$. 


\section{Plant Department}

\section{Our Sturdy Southern Grown Cabbage Plants are Tough and Hardy-They Mean Dollars to the Wide-Awake Gardener}

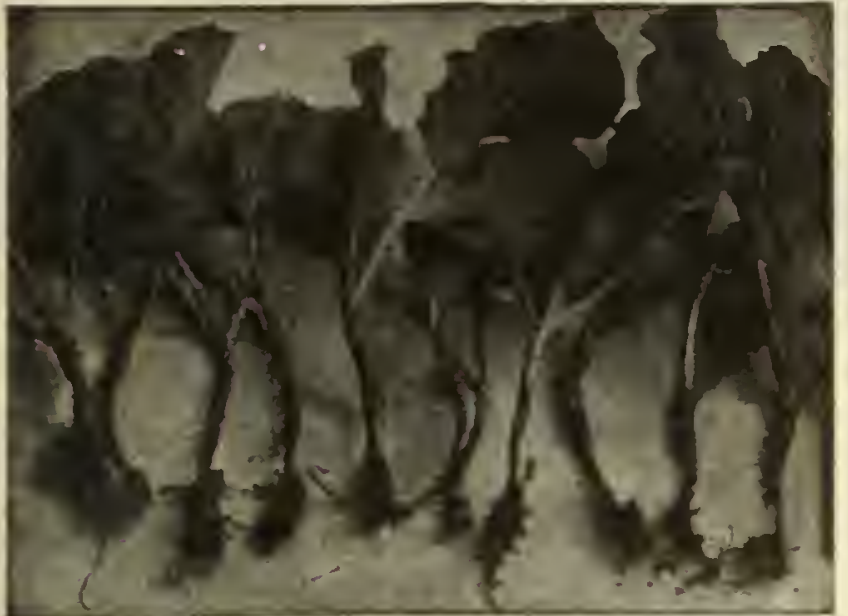

Frost-proot Cabbage Plants.

The plants make a slow but steady growth, until at eight or ten weeks of age they are very tough. the buds are purple and the outer leaves a reddish brown. When in this condition they can be shipped to territory farther north and be planted in the open ground a month to six weeks sooner than the home-grown hotbed or coldirame plants. These Frost-prool Cabbage Plants will stand a temperature of twenty degrees above zero without injury, the land freezing, or the plants being covered with ice. sleet or snow after they are planted will not injure them.

The top of the plant does not grow until your regular Spring weather opens up, but the roots grow from the time they are planted, and just as soon as Spring weather starts, the established root growth assimilates the fertilizer in the soil, the plants grow very fast, maturing headed cabbage two to three weeks sooner than you can mature them from hotbed and coldirame plants. You know what the difference in profit will be if your crop is matured and marketed before the general crop from home-grown plants is matured.

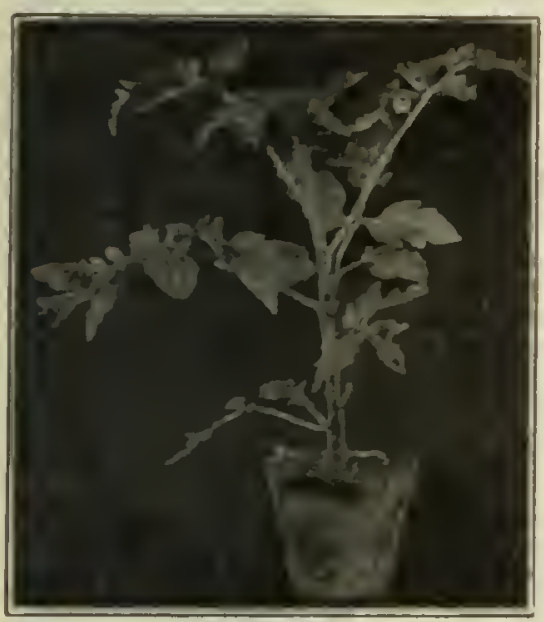

To get the ad. vantage of these Frost-Prool Cab. bage Plants they must be planted a month or six weeks e a r ll ex than you would plant home. grown plants.

Our cabbagc plants are grown from the best Long lsland grown seed. We can fill orders from November lst to May 1 st.

The plants when received will be somewhat wilted and have a hard. stunted appearance which will be disap pointing to persons who have never used these plants before. Regardless of appearance, they will produce the crop results. IVe do not guarantec delivery. Our responsibility ceases upon delivery of plants to post-office or transportation company.

\section{HORSERADISH RUOTS}

Ready In March

Mallaer Kren (Bohemian). Large. strong cutlings, 35 cts. per doz.; per 100, \$2.00; $\$ 15.00$ per 1.000 .

If Horscradish are wanted by mail, add $10 \mathrm{cts}$ per 100 for postage.
Varieties-Early Jersey Wakefield, Charleston Large Type Wakefleld, Succession and Early Flat Dutch, Copenhagen Market and other varieties.

Prices by parcel post, postage paid, $50 \mathrm{cts}$. per hundred; 200 or more at 35 cts. per hundred.

Prices by express, buyer paying charges, 1,000 to 4,000 at $\$ 2.50$ per thousand; 5.000 to 8.000 at $\$ 2.40$ per thousand; 10.000 and over, $\$ 2.25$ per thousand.

Write or wire for quantity prices.

Terms, cash with order.

Write for prices on plants not quoted, also prlces on vegetable and flower plants in large quantltles.

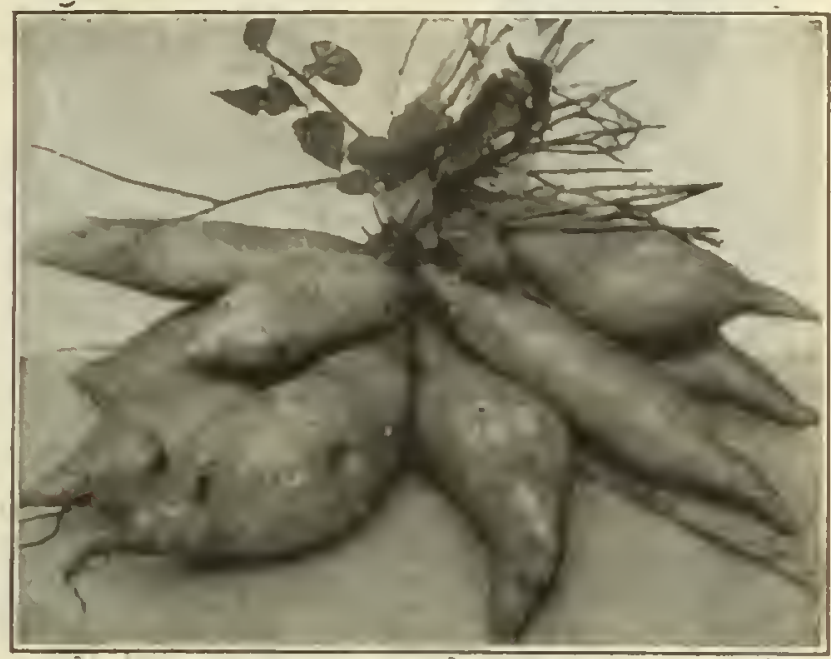

Porto Rlco Sweet Potatoes.

SWEET POTATOES

Porto Rico, Nancy llall, etc., per 1.0000 ........\$3.00

\section{Plants in Season}

Asparagus Roots, $\$ 1.50$ ner 100

Rhubarb Roots, $20 \mathrm{cts}$. cacli, $\$ 1.75$ per doz.

Tomato Plants, $25 \mathrm{cts}$. per doz.. \$1.00 per 100.

Collard Plants, $30 \mathrm{cta}$, per $100, \$ 2.50$ per 1000

Egeplants, $60 \mathrm{cts}$. per doz.

Celery Plants, $\$ 1.00$ per 100, $\$ 6.00$ per 1000.

Caullflower Plants, $60 \mathrm{cts}$. per 100.\$5.00 per 1000

Pepper Plants, 30 cts. per dez. $\$ 2.00$ per 100

Lettuce Plants, best varictics, 50 for $30 \mathrm{cts} ., 100$ for 50 cts., 1000 for \$4.00. Quantity prices on request.

Strawberry Plants, \$1.25 per $100 . \$ 11.00$ per 1000

Flower Plants and Bulbs, all varleties. Send llat for prlees.

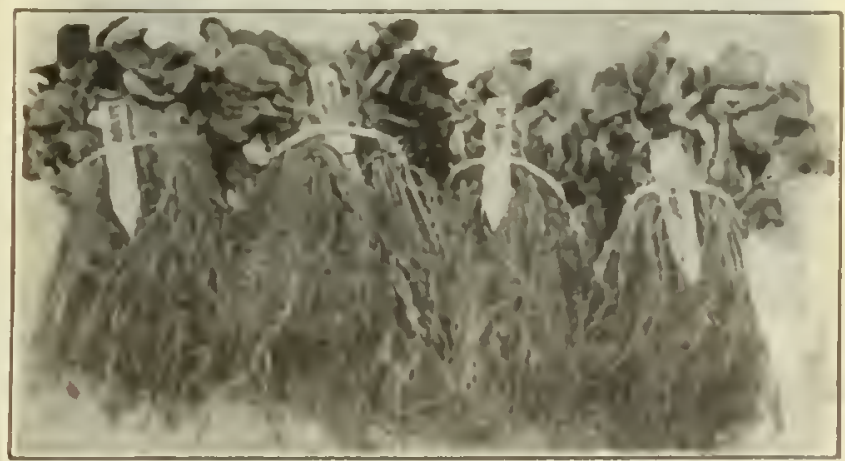

Strawbertes for Home Use or Market. 


\section{Chinese or Celery Cabbage, Pe-Tsai}

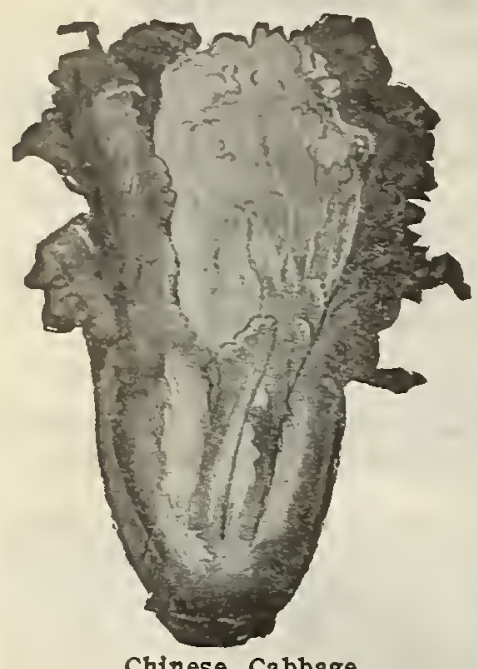

Pe-Tsai. A wonderful salad plant, growing 15 to 16 inches high, somewhat resembling Cos Lettuce, or probably more like Swiss Chard. Cut up like Cabbage, and served with mayonnaise or French dressing, it makes a splendid coleslaw. Can be boiled like cabbage if cooked quickly and served with cream sauce, but is without the strong flavor and odor of Cabbage. The hearts blanch to a crystalline white, whiter than lettuce and more beautiful than $\mathrm{Cab}-$ bage-every leaf, including the outside ones, is delicate and tender. Pe-Tsai should be of special interest to poultrymen; it is an economical and prolific green food. Sow early in the spring and again in July and August, transplanting 18 inches apart in $21 / 2 \mathrm{ft}$. rows. Pkt. $10 \mathrm{cts}$., oz. $25 \mathrm{cts} ., 1 / 4 \mathrm{lb}$. $75 \mathrm{cts}$., Ib. $\$ 2.50$, postpaid.

\section{CELERY}

One ounce to sow 100 feet, will produce about 4,000 plants; 8 ounces to set one acre.

Sow seed in February, March or April, in rows of fine rich soil, and if dry enough, press the soil firmly with a roller or the back of a spade. Keep the seed-bed well watered, as Celery germinates slowly. When 4 inches high cut tops to make the plants grow stocky. Transplant from June to September, in rows 3 feet apart, 6 inches apart in the row. Matures from 120 to 160 days.

Winter Queen. The best winter Celery. It blanches easily, has a crisp, nutty flavor, is hardy and a splendid keeper. Pkt. 10 cts., oz. 30 cts., $1 / 4$ lb. 75 cts., lb. $\$ 2.50$.

Giant Pascal. Thick, solid stalk, golden hearts; blanches quickly; keeps well and is of good flavor. Pkt. 10 cts., oz. 30 cts., $1 / 4$ lb. 75 cts., lb. $\$ 2.50$.

White Plume. One of the best for early use; handsome; good quality; blanches easily. Pkt. $10 \mathrm{cts}$., oz. $30 \mathrm{cts}$., $1 / 4$ lb. 75 cts., lb. $\$ 2.50$.

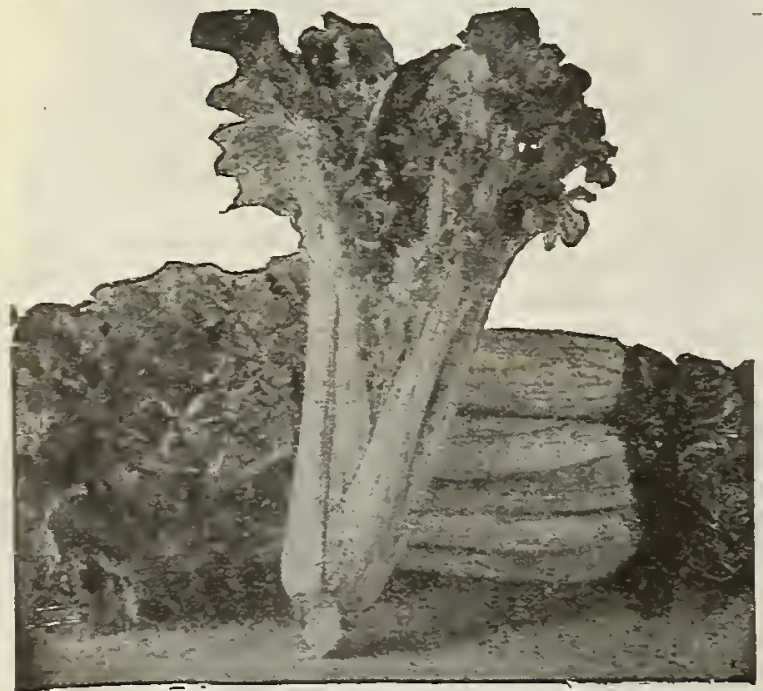

Golden Self-Blanching Celery.

Golden Self-Blanching. Not so early as the White Plume, but is of a heavier and more compact growth. Its stalks are thick, crisp, and brittle. Pkt. 10 cts. oz. 40 cts., $1 / 4$ Ib. $\$ 1.25$.

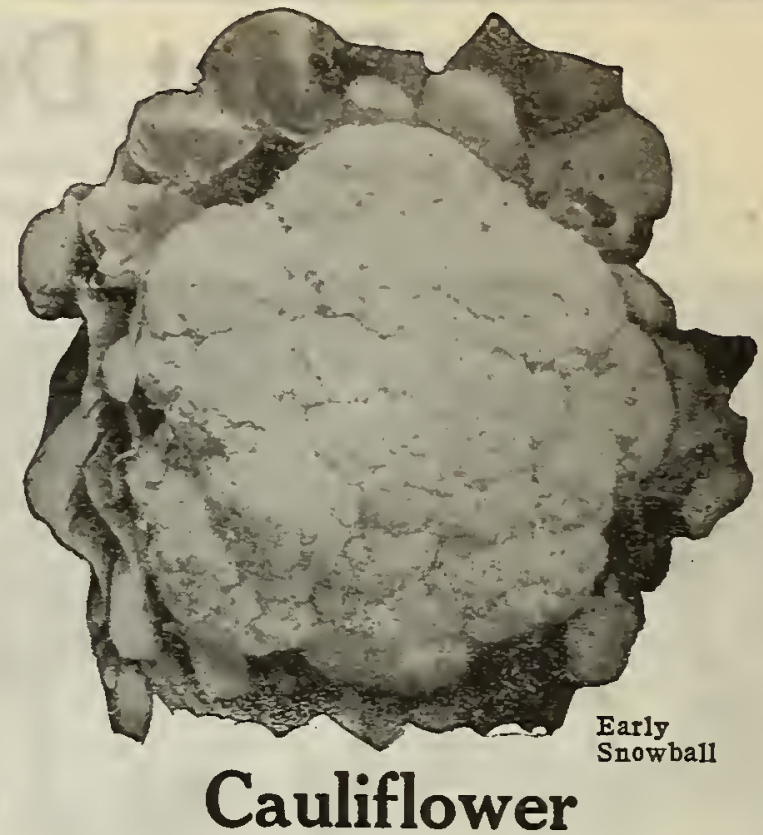

One ounce will produce aboùt 2,000 plants

For best success sow Cauliflower seed in hotbed or cold frame during January.

Early Snowball. An extremely early dwarf variety, producing magnificent white heads in 90 days. The plants make a compact growth, with short outside leaves, and produce heads of medium size. Well suited for hotbed culture. Pkt. 20 cts., $1 / 4$ oz. 60 cts., oz. $\$ 2.00,4$ oz. $\$ 6.00$
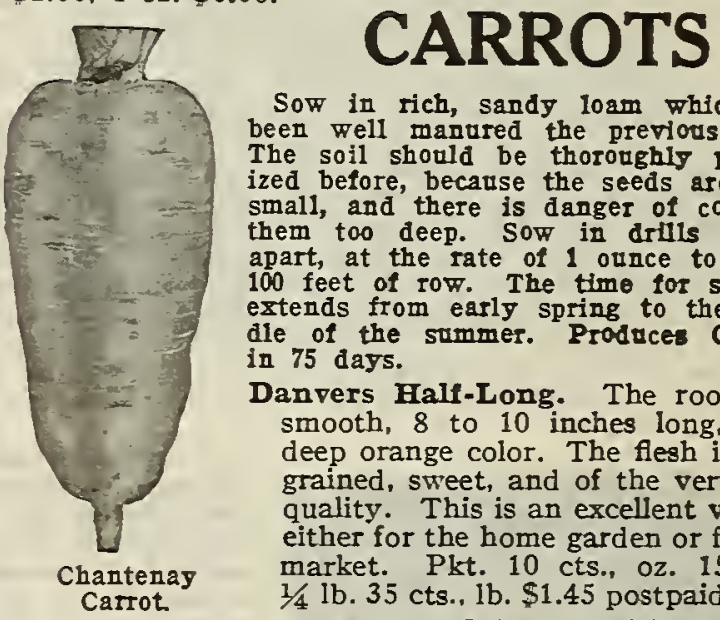

Sow in rich, sandy loam which has been well mantired the previous year. The soil should be thoroughly pulverized betore, because the seeds are very small, and there is danger of covering them too deep. Sow in drills 2 leet apart, at the rate of 1 ounce to erer 100 feet of row. The time for seeding extends from early spring to the middie of the summer. Produces Carrots in 75 days.

Danvers Hall-Long. The roots are smooth, 8 to 10 inches long, of a deep orange color. The flesh is fine grained, sweet, and of the very best quality. This is an excellent variety either for the home garden or for the market. Plt. 10 cts., oz. 15 cts., $1 / 4$ Ib. 35 cts., Ib. $\$ 1.45$ postpaid.

Chantenay. Suited to either garden or field culture. It has a medium-sized top, small neck, stump root and a broad, thick shoulder. The roots are of an orange color, and the flesh is of good quality. Pkt. 10 cts., oz. 15 cts., $1 / 4$ lb. 35 cts., 1b. $\$ 1.25$. postpaid. Not postpaid, 5 lbs. $\$ 5.00$.

Improved Long Orange. The roots grow uniform and smooth, 8 to 10 inches long, of large size and deep, rich orange color. It is a good keeper and of fine quality for table use, also highly nutritious for stock. Ready for table in 75 days. Pkt. 10 cts., oz. 15 cts., $1 / 4$ lb. 45 cts., lb. $\$ 1.00$ prepaid. 5 lbs. for $\$ 4.00$, not prepaid.

Oxheart, or Guerande. One of the most popular and heaviest yielders among the short Carrots. The shape is particularly desirable for heavy soils. It tapers slightly to the bottom, and is very stump-rooted: Pkt. $10 \mathrm{cts}$., oz. $15 \mathrm{cts}$., $1 / 4 \mathrm{lb}$ l 45 cts., lb. $\$ 1.25$.

\section{Celeriac or Turnip-Rooted Celery}

In this kind of celery, the roots have been developed by cultivation and not the leaf-stalks. The roots, which are edible portion, keep rell for winter use and are excellent for soups and stews. They are also cooked and sliced as a salad.

Giant Smooth Prague. Plt. $10 \mathrm{cts} ., 0 z .35 \mathrm{cts} ., 1 / 4$ lb. $\$ 1.00,1 b . \$ 3.00$ 


\section{SWEET, or SUGAR CORN}

One-half pound will plant 150 feet of row: 12 pounds to the acre

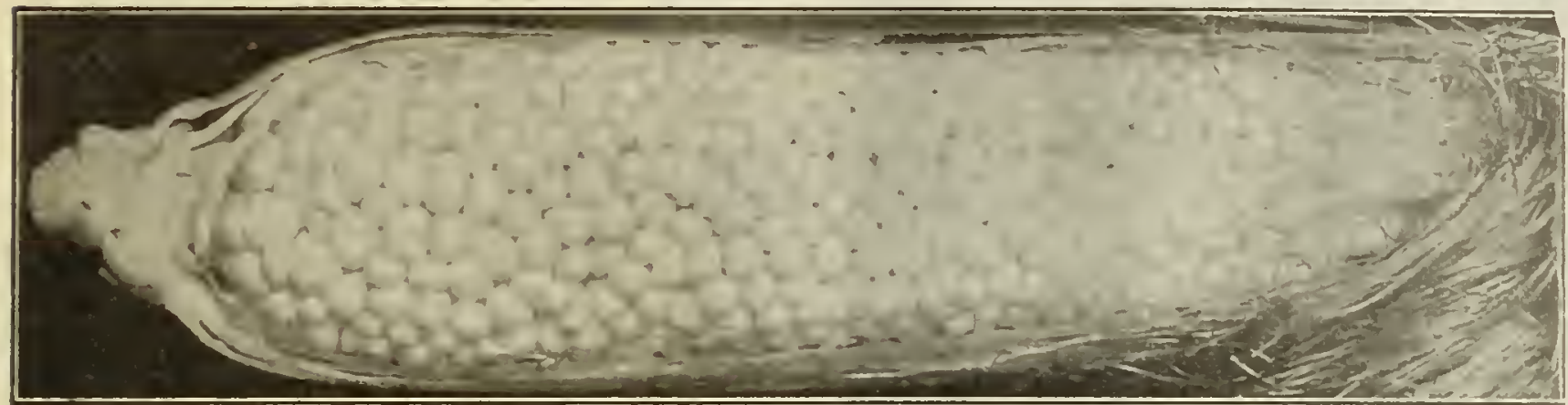

Country Gentleman.

Plant 5 or $6 \mathrm{gralns,} \mathrm{1//8} \mathrm{Inches} \mathrm{deep,} 3$ feet apart, In rows 3 feet apart. When plants are 4 laches high pull out all but two plants to the hill. For very early Corn, the hardiest and earliest rarletles can be planted the latter part of March, if the weather is mild, bat Sweet Corn should not be planted until April, or until the spring weather opens and the ground gots warm, as it has a tendency to opens and the ground gots warm, as it has a tencency tinued cold or raing spell of weather. It should be planted at intervals of every two weeks nntil Jnly or August so as to bave Corn for nse during the eature season. Roasting ears in 60 to 80 days.

For table use the Sweet Corns are far and away ahead of all other varieties. While they cannot be planted quite as early as the first of the Fleld Corns their quality is $\mathbf{8 0}$ superior that no garden should be without a good planting. Good prices can always be obtained, and the crop is a very profitable one for the market gardener.

Golden Bantam. The earliest and best of Sugar Corns. It is golden color and delicious flavor, with the sweetness of honey. The stalks are dwarf in habit, growing about four feet high, producing two or three good ears, 5 to 6 inches long, well set from the ground. Pkt. $10 \mathrm{cts.}$ lb. 30 cts.. post paid. By freight or express, 5 1bs. $\$ 1.25$, 10 lbs. $\$ 2.25$, pt. $30 \mathrm{cts.,} \mathrm{at.}$ 50 cts. 100 ibs. at 16 cts

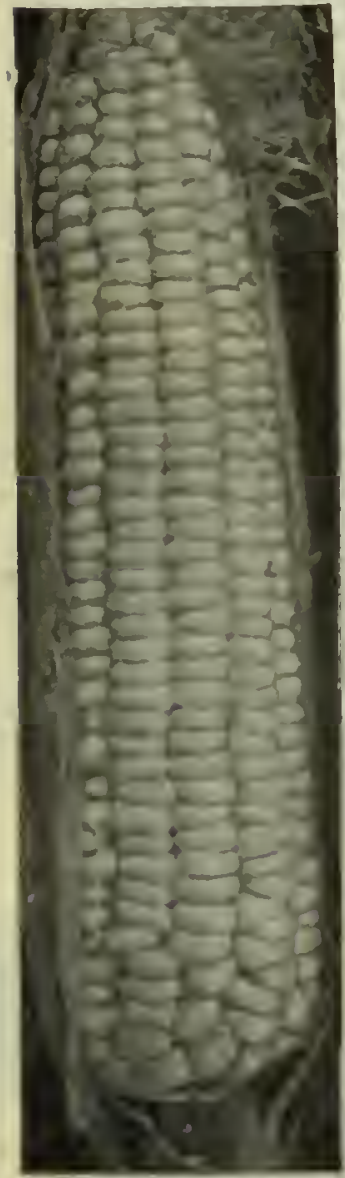

Country Gentleman. Considered one of the best quality Sweet Corns for table use and canning. Has long, deep grains, and yields two to four cars to the stalk. Pkt. 10 cts., Ib. 30 cts.. post paid. Not prepaid. $25 \mathrm{cts}$ lb.. pt. 30 cts.. qt. 50 ets.

Stowell's Evergreen. The standard and best known Sweet Corn. Ears 8 inches long, 10 to 20 rowed with very deep. sweet grains. Pkt. $10 \mathrm{cts} . .16 .30 \mathrm{cts} .0$ lbs. 55 cts. By freight or express, 5 lbs., \$1.25, 10 lbs. $\$ 2.25,100$ ibs. $\$ 16.00$

\section{DeLue's Golden}

\section{Giant}

Delue's Golden Giant Sweet Corn. You know how tenderly delicious and swect Golden Bantain is. Those who lave grown Golden Giant say it is just as good to cat and yet is 50 to 75 per cent larger. The ears have 12.16 rows of very deep, luscious golden $\mathrm{ker}$ nels. Pkt. 15 ets., $16.45 \mathrm{cts}$. prepaid. Not prepaid, 3 lbs. $\$ 1.00,10$ lbs. $\$ 3.00,25$ lbs. $\$ 675$

KIndly send us names and ad dresses of your eardener fricnd and we will mall them our cat
Black Mexiean. One of the sweetest and tenderest corns in cultivation. The sced is bluc, but in the roasting ear state is a clear whitc. Pkt. 10 cts.. 1 lb. 30 cts. 2 lbs. 50 cts.. postpaid. By freight or express, 5 lbs. $\$ 1.00,10$ lbs. $\$ 1.75$

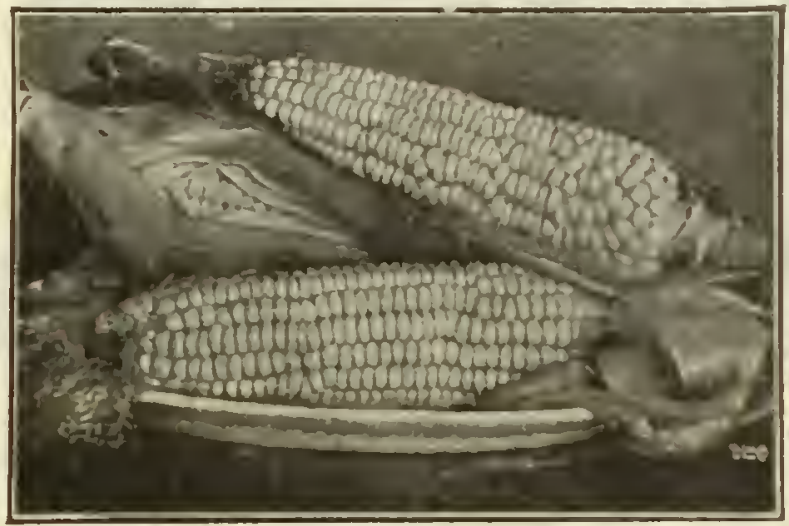

Stowell's Evergreen.

Golden Rod. Long ear, yellow grains, delicious. Pkt. 10 cts.. 1b. 35 ets.. 2 lus. $65 \mathrm{cts}$.

Metropolitan. White, large, sweet extra quality. Plt. 10 cts. pt. 35 ets. Qt. 65 cts.

White Evergreen. Mid-season, gnod for honc gardcn. Pkt. 10 cts., pt. 35 cts.. qt. 65 cts.

\section{CHICORY}

Witlool Chicory or French En dive. Adelicious vegetablc very easily grown. The roots, from which the tender white stalks that are used for cating are grown, are ralsed from seed which should be soun early in June, in drills. In November the roots are dug and the tops cut off. leaving about one and a half inches of the leat stalks. These roots are then planted out of doors for tise the following spring, or tlicy can bc lorced in boxes inside. In either casc the roots arc set in sand or soi in upright positions with tops about six inches below the surface. The tender shoots can be used as a malad raw, or are dclicious cooked. Pkt. 10 cts., oz. $30 \mathrm{cts.}$ 1/s lb. $60 \mathrm{cts} .$. Ib. $\$ 1.75$

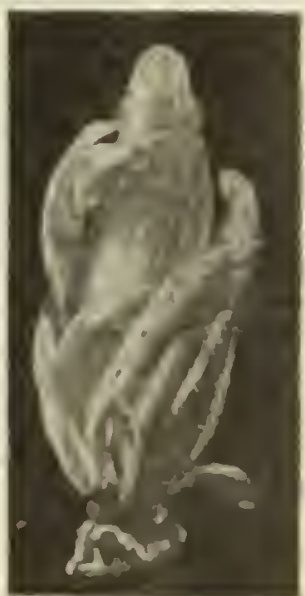

Calcory
SPACE-SAVING SUGGESTIONS

In the small home garden where space is at a memiunflentimea two or even llirec crops can lye frown logelher. all of them taking up no more space than one alone. liere re a few combinations that have been found to work well: Corn and rucumbers. Late Peas and Swect Corn.

Potatocs (Early) and Latc Swect Cora.

Swect Corn and Squnsh or Pumpkins.

Early Pens, Lettuco and Tomatocs. 


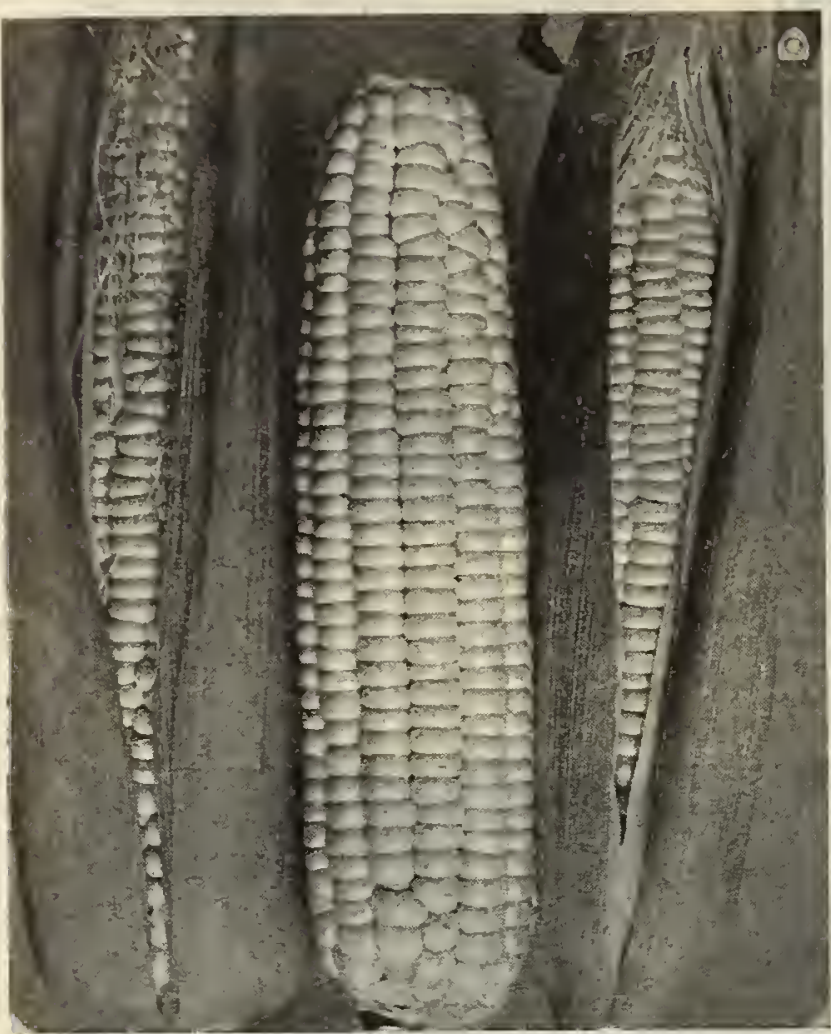

Improved Adams Early Corn.

\section{ROASTING EAR CORN}

Improved or Large Adams' Early. An improvement in the old Adams' Early, being nearly one-third larger and almost as early. Pkt. $10 \mathrm{cts.,} \mathrm{1b.} 30 \mathrm{cts} ., 2$ lbs. $50 \mathrm{cts.}$, prepaid. Not prepaid, $5 \mathrm{lbs} .80 \mathrm{cts}, 10 \mathrm{lbs}$. $\$ 1.25$.

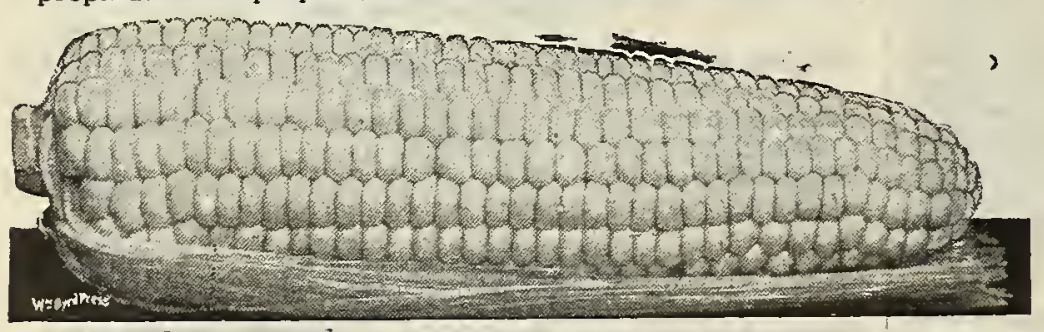

Wyatt's Snowflake Corn.

\section{BROCCOLI}

Requires a longer season than either cabbage or cauliflower to develop. The same cultivation as suggested for lower to develop. bie given to Broccoli. Sow seed early in cauliflower should be given to Broccoli. Sow seed early in flower but far more hardy.

Early White Cape. The best variety. The heads are white, compact, and hard, and it is a hardy, vigorous, and easily grown sort. Pkt. 15 cts., $1 / 20 z .40$ cts., oz. 75 cts.

\section{CRESS}

Fine Curled (Pepper Grass). Pkt. 10 cts., oz. 20 cts. $1 / 4$ lb. 50 cts., 1b. $\$ 1.50$.

True Water. Pkt. 10 cts., oz. 60 cts., $1 / 4$ lb. $\$ 2.00,1 b$ $\$ 6.00$.

\section{Corn Salad, or Fetticus}

A most refreshing salad, especially for winter use; can also be cooked and used like spinach. Plant is of quick growth and hardy. For spring crop sow seed $1 / 2$ inch deep in rows 1 foot apart and thin to 6 inches in row. For extra early crop, sow seed in September or October. For fall use, a sowing should be made in July or August. One ounce will plant a row 50 feet long. Is ready for table in 60 days. Pkt. 5 cts., oz. 15 cts., $1 / 4$ lb. 45 cts., $1 \mathrm{~b} . \$ 135$, ppd.
Adams' Early. While not a Sugar Corn, is a tender white corn for the table; can be planted earlier and will be ready in 60 days. Pkt. 10 cts., lb. $30 \mathrm{cts} ., 2$ lbs. 50 cts., prepaid. Not prepaid, 5 lbs. $80 \mathrm{cts}$, 10 lbs. $\$ 1.25$. Wyatt's Snowflake. It is larger than Trucker's Favorite, but not quite so early. The stalks grow large and vigorous, bearing several large, well-filled ears. The grains are rather large, deep, and pure white. Pkt. 10 cts., 1b. 30 cts., 2 lbs. 50 cts., prepaid. Not prepaid, 5 lbs. 80 cts., 10 lbs. $\$ 1.25,1$ pt. 25 cts., 1 qt. 40 cts.

Trucker's Favorite. A splendid early white corn, coming in directly after Adams' Early, but much larger; has a deep, white, soft grain. Pkt. 10 cts., lb. 30 cts., 2 lbs. 55 cts., prepaid. Not prepaid, 5 lbs. 90 cts., 10 lbs. $\$ 1.50,1$ bu. $\$ 5.50,5$ bus $\$ 5.25$.

Norfolk Market. Ears will average 8 inches in length A very prolific, popular variety. Pkt. $10 \mathrm{cts}$., lb. $30 \mathrm{cts}$. 2 lbs. 50 cts., prepaid. Not prepaid, 5 lbs. 90 cts., 10 lbs. $\$ 1.50,50$ lbs. at 12 cts.

Garden Corn on Ear. For seed purposes. Extra fine ears. $10 \mathrm{cts}$. each, $\$ 1.00$ per dozen ears. Postage 15 cts. doz. extra. $\$ 7.50$ per 100 ears, not prepaid.

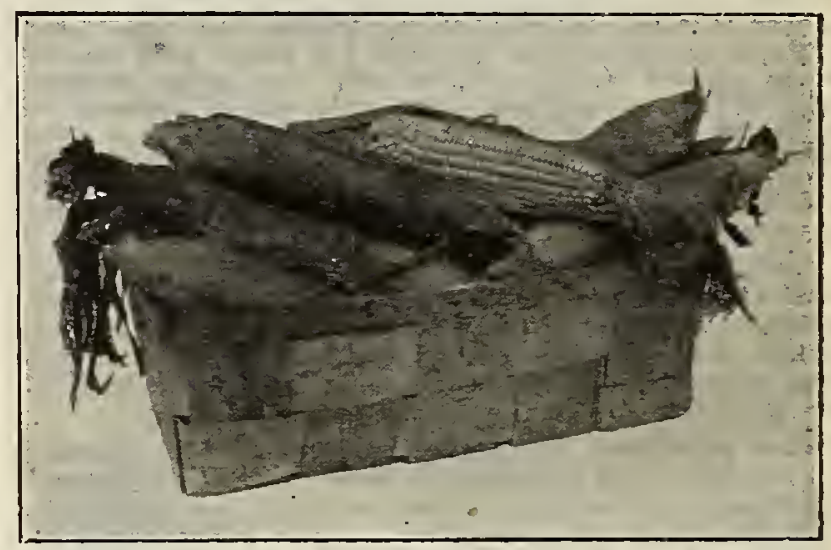

Basket of Truckers' Favorite Corn. This Variety Always Brings Top Prices on All Markets.

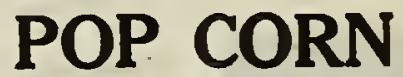

Your Crop W111 Give You Many Winter Evenings of Pleasure.

Queen's Golden. Stalks grow 6 feet high, with large ears produced in abundance. It pops perfectly white, and a single kernel will expand to a diameter of nearly one inch. Pkt. $10 \mathrm{cts} ., 1 / 2$ lb. 20 cts., lb. 30 cts., postpaid. By freight or express, 10 lbs. for $\$ 1.50,50$ lbs. at $14 \mathrm{cts}$.

White Rice. The popular and widely known variety. The kernels are pointed and resemble rice. It matures later than other varieties but yields heavily and "pops" fine. Pkt. 10 cts., $1 / 2$ lb. 20 cts., lb. 30 cts., postpaid. By freight or express, 10 lbs. $\$ 1.50,100$ lbs. at 12 cts.

Red Beauty. A prolific variety with deep red ears. Pops white. Pkt. 10 cts., lb. 30 cts., postpaid. By freight or express, 10 lbs. for $\$ 2.00$.

Mapledale Prolific. Same price as White Rice.

Pop Corn for Popping. Lb. 12 cts., 5 lbs. 55 cts., 10 lbs. $\$ 1.10,100$ lbs. $\$ 10.00$ If wanted by mail. add 5 cts. per pound for postage.

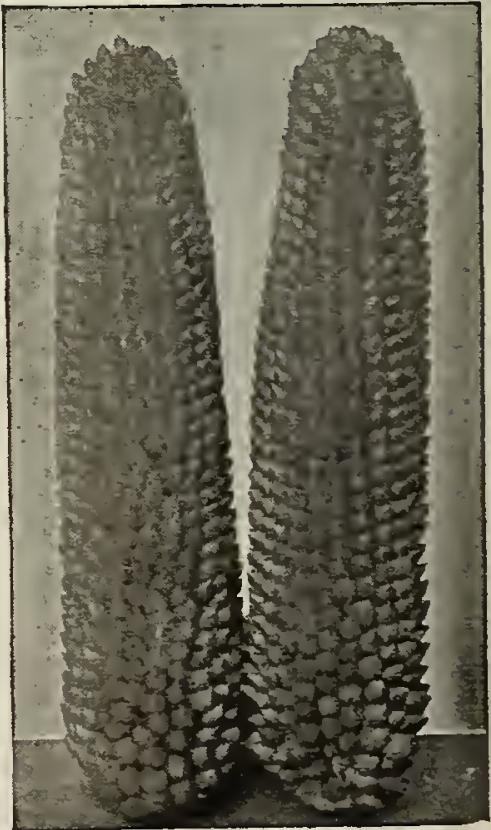

White Rice Pod Corn.

BEAUTIFY YOUR HOME GROUNDS BY PLANTING GLADIOLI. You will be well pleased. See page 44. 


\section{CUCUMBERS}

One ounce plants about 50 hills; 2 lbs. plants an acre An early crop of Cncumbers can be had each year by starting the seed in pots, boxes, or on a piece of sod so they can be readily transplanted without checking the growth. For outside planting, the gronnd should be prepared and put in good condition and the seed should be planted about the latter part of April or the first part of May in this particular lattude. The seeds should not be planted more than an inch deep and in hills slightly raised above the ground, about feet apart each way. We also recommend planting about two or three times as much seed as you would for any other crop and then thin out or pull out the plants, as the insects attack the pines which are the weakest, leaving about three or fonr strong vines to each hill. The Cucumbers are ready for use about two months after planting.

We Wull Quote Special Quantity Prices to Truckers Gherkin or Burr. Small prickly; used for pickles only. Pkt. $10 \mathrm{cts.,}$ oz. $25 \mathrm{cts} .1 / 4 \mathrm{lb} .65 \mathrm{cts}$., postpaid.

Japanese Climbing. Grow's quickly on poles or trcllis, takes up little room in the garden. Fruit is good sizc. fine flavor, cspecially good for slicing and salads; does best in dry warm summers. Pkt. $10 \mathrm{cts}$. 0z. $20 \mathrm{cts}$. $1 / 4$ lb. 60 cts., lb. $\$ 2.00$.

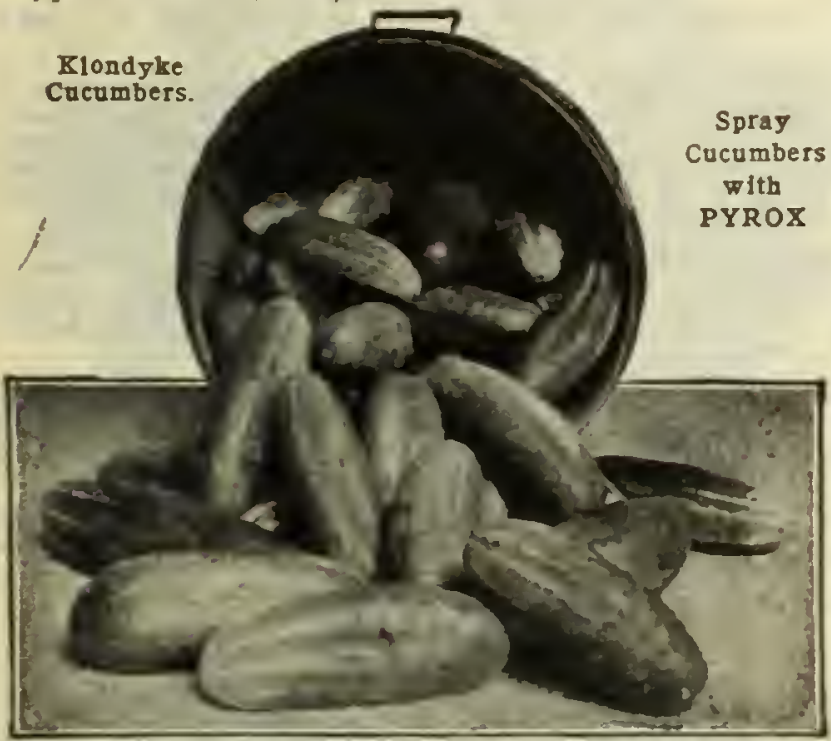

Klondyke. Very hardy, resisting unfavorable weather conditions and is a good sizc for slicing. It is also quite firm when small and is crcellent for pickling. Matures in 60 days. Pkt. $10 \mathrm{cts..}$ oz. $15 \mathrm{cts.} 1 / \mathrm{lb} .40 \mathrm{cts.} .1 \mathrm{~b}$. $\$ 1.25$, postpaid. $10 \mathrm{lbs}$. for $\$ 9.00$.

Davis Perfect. A highly popular shipping varicty bccause of its decp grecn color. Fruit long, rather slender, beautiful decp grcen color, few seeds. 1'kt. 10 cts., oz. 15 cts.. 31 lb. 45 cts., 1b. $\$ 1.45$, postpaid.

Thorburn's Everbearing. An extremcly sinall early pickling varicty. Pkt. $10 \mathrm{cts}, 02.25 \mathrm{cts} ., 1 \mathrm{~s} 1 \mathrm{~b} .65 \mathrm{cts}$.

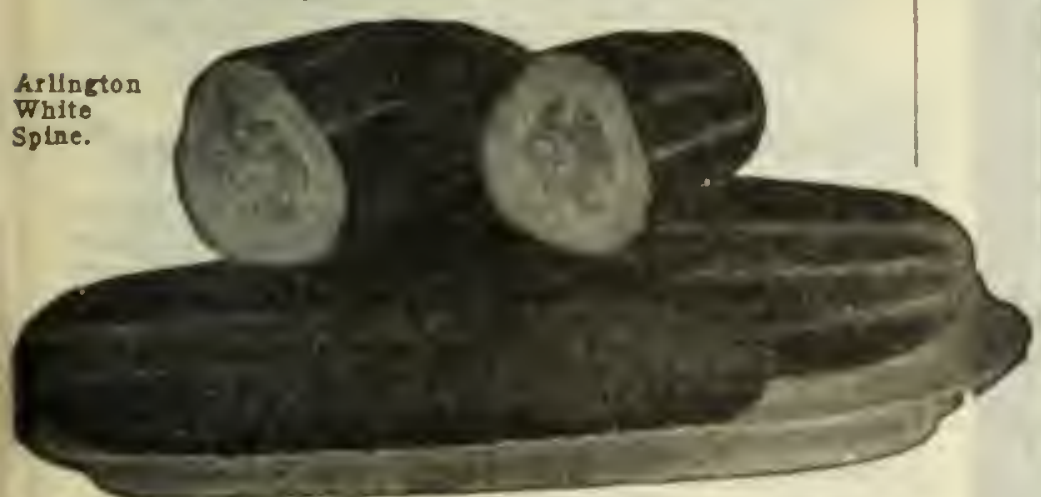

Green Prolific. Vcry prolific; espccially recommended for picklcs. Pkt. 10 cts., oz. 15 cts.. 1' 1b. 45 cts.. 1b. \$1.50. postpaid.
Early Fortune. An extra-early Cucumber of the White Spine type. Very productive; fruits 8 inches long, slightly tapering. Color dark green. Pkt. $10 \mathrm{cts.,} \mathrm{oz,}$ 15 cts., $1 / 4$ lb., 40 cts., lb. $\$ 1.25$. post paid. Not prepaid. 5 lbs., $\$ 1.00$ per lb., 10 lbs. for $\$ 9.00$.

Early Green Cluster. They are very prolific, and frequently set in clusters of two and three. If the fruits are kept gathered, the vines will continue long in bearing. Pkt. 10 cts., 0z. 15 cts., $1 / 4$ lb. 40 cts., lb. $\$ 1.25$, post paid.

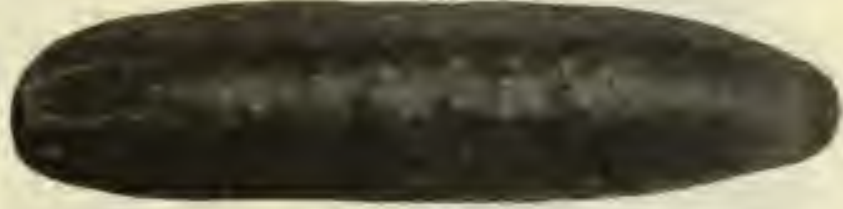

Improved Long Green.

Improved Long Green. Well-known table sort, 12 to 14 inches long; slender, more tapering toward the stem end; color dark green; flesh white and firm. Pkt. 10 cts., oz. $15 \mathrm{cts.}, 1 / 1$ lb. $45 \mathrm{cts.,} \mathrm{1b.} \mathrm{\$ 1.50,} \mathrm{postpaid.}$

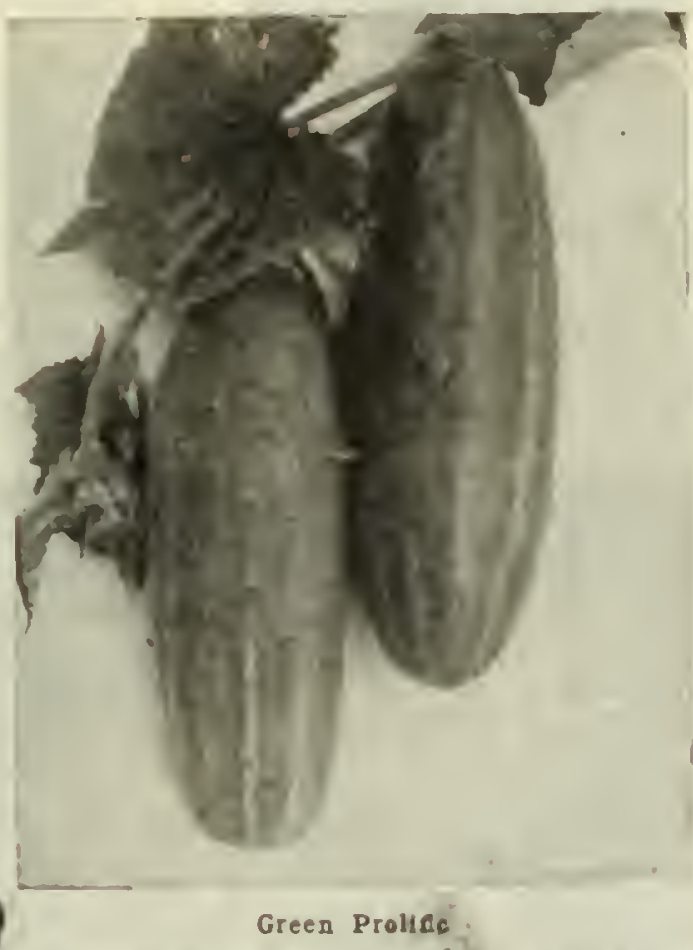

Arlington White Spine. One of the earlicst and anost productive of the Whic spinc family; true in tyme and uniform. Fruits about 7 inches long. rousuder at leuth ends and of bright, deep green culor. I'kt, 10 cta., (17, 15 cts.. 1/4 16. 40 cts.. 16. \$1.25, pest paid. 5 lbs. at $\$ 1.00 \mathrm{lb}$. 


\section{COLLARDS}

One of the most popular southern vegetables and largely used in place of cabbage. It is hardier and easier to grow than cabbage, can be grown on poorer soil, and withstands insect attacks better.

Although often sown during the spring and summer, the principal sowings are made in June, July and August, transplanted a foot apart in the row and given frequent cultivation. They make a most excellent regetable for the late fall, winter and early spring. The flavor is improved by frost. Cultivate like late cabbage. Ready for use in about 75 days.

North Carolina Short-Stem. A decided improvement, and has proved very popular wherever grown. Has a short stem; large spreading leaves; very hardy, withstanding drought in summer and cold in winter. Its flavor and cooking qualities are the very best. Pkt. 10 cts., oz. 15 cts., $1 / 4$ lb. 35 cts., lb. $\$ 1.00$, postpaid. By express, lb. $90 \mathrm{cts}$.

Cabbage Collard. Called "Cabbage Collard" because of its close bunching habit and general resemblance to cabbage. As white and crisp as cabbage. Pkt. 10 cts.,

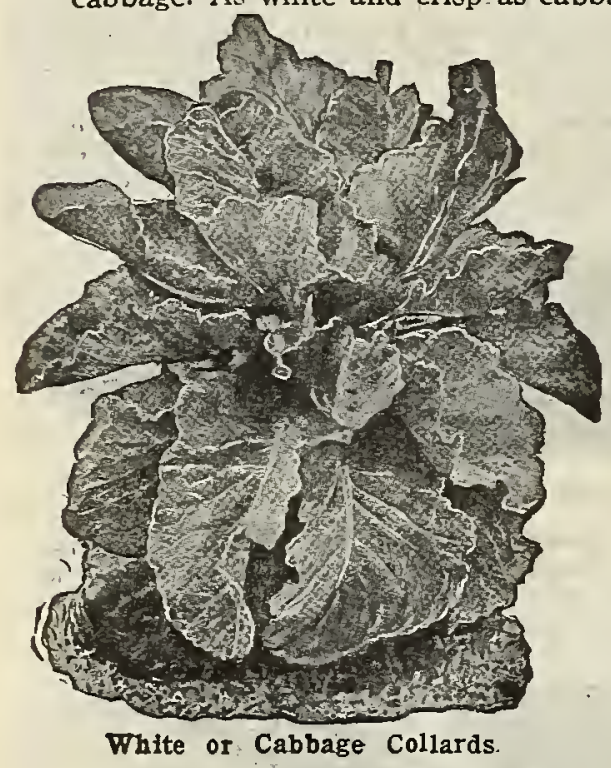
oz. $15 \mathrm{cts} ., 1 / 4$ lb. 40 cts., lb. $\$ 1.35$, p o s tpaid. By express, 1 b. $\$ 1.25$.

True Georgia, or Southern. The we ll$\mathrm{kn} \circ \mathrm{w} \mathrm{n}$ and popular C o llard that has been grown for generations in the South. Should have a place in every Southern garden. Pkt. 10 cts., oz. 15 cts., $1 / 4$ lb. 35 cts. lb. $\$ 1.00$, postpaid. By express, $1 \mathrm{~b}$. 90 cts.

\section{GOURDS}

Nest-Egg. The small, white fruits of this variety resemble exactly in color, form and size the eggs of hens. When properly dried they are light and durable. As they do not crack and are uninjured by cold or wet, they make the best of nest-eggs. Grown on a trellis, the vines serve as an ornamental screen. They should not be grown in a very rich soil, or fruits will become too large for nest-eggs. - They are also useful for stocking darners. Pkt. 10 cts., oz. 20 cts., $1 \mathrm{~b}$. $\$ 2.50$.

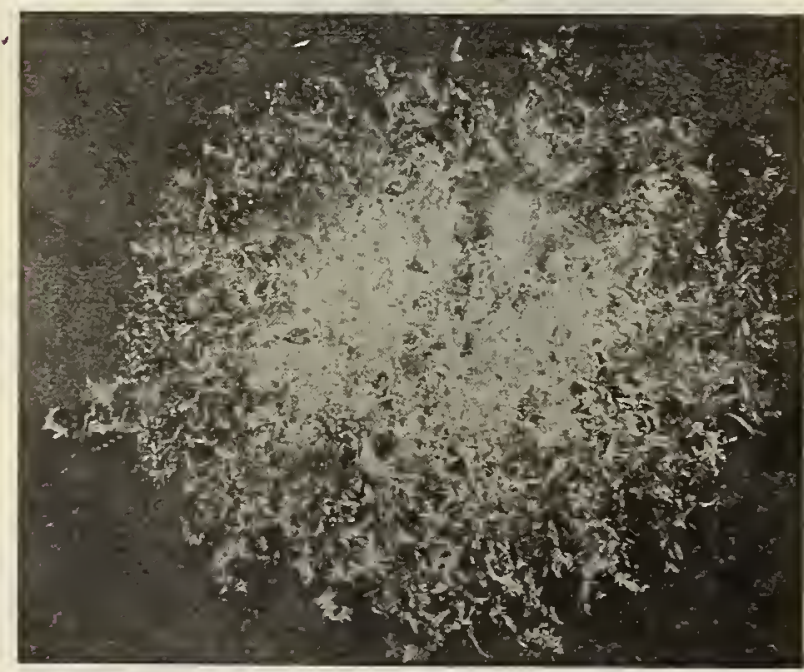

Green Curled Endive.

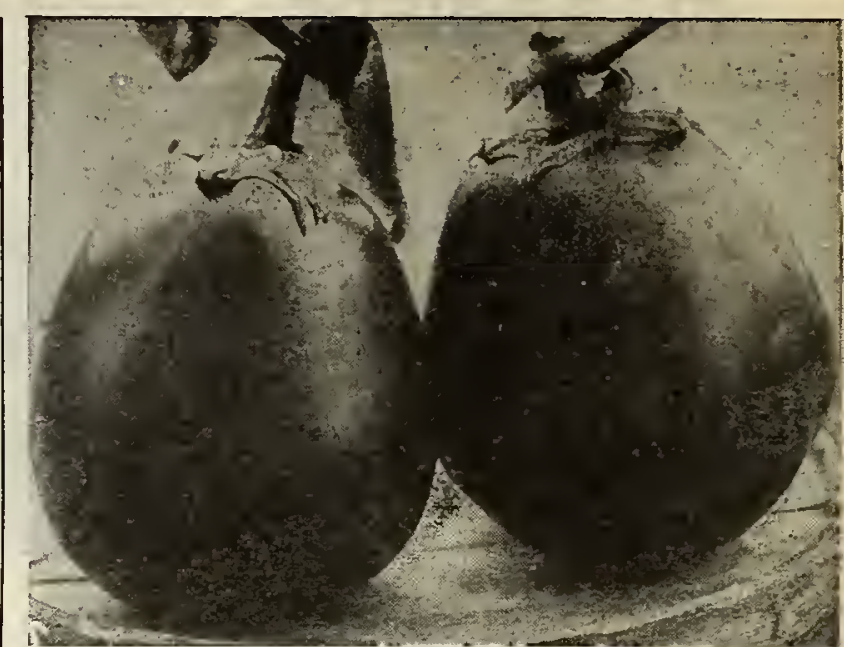

Black Beauty Egg Plant.

\section{EGG PLANT}

One ounce of seed will produce 2,000 plants; $1 / 4$ pound will sow an acre.

Sow in hotbeds during February and March, and when 3 inches high transplant into small pots or otherwise. Plant out of doors after the weather has become perfectly warm. The rows should be 3 feet apart and the plants set 2 feet apart in the row. Hoe frequently to keep soll loose and fine. Matures in about 120 days.

Black Beauty. Fully as large as the New York Improved. and about 10 days earlier. Very rich, dark purple, spineless. Pkt. 10 cts., $0 z .40$ cts., $1 / 4$ lb. $\$ 1.25$, lb. $\$ 4.75$. postpaid. By express, $\$ 4.50$ per $1 \mathrm{~b}$.

New York Improved Purple (see inside back cover). This popular variety is of low growth, very compact and forms perfect support for its fruit. Usually makes 8 to 10 fruits before frost, of superb quality, which are smooth; glossy deep purple in color. Pkt. 10 cts., oz 40 cts., $1 / 4$ lb. $\$ 1.25$, lb. $\$ 4.75$, postpaid. By express, $\$ 4.50$.

\section{ENDIVE}

One ounce will sow about 200 feet of drill

When plants are well started thin out to 10 inches apart in the row, or they may be transplanted to fresh rows. When plants have reached a good size gather the leaves closely together and tie loosely in an upright bunch. This bleaches the inner leaves in about ten days and adds to the crispness as a salad, as it renders the flavor mild and delicate. One ounce will sow 100 feet of rows; 3 1bs. will plant 1 acre of land in rows 3 feet apart.

Green Curled. An attractive and appetizing salad for the fall and winter. Has fine-cut leaves, giving it a mossy appearance. Sow in August in 18-inch drill, and later thin plants to 1 foot apart; when large, tie up outer leaves to blanch. In dry seasons give plenty of water. Pkt. $10 \mathrm{cts.}, 0 z .15 \mathrm{cts}, 1 / 4 \mathrm{lb}, 40 \mathrm{cts} ., \mathrm{lb}$. $\$ 1.50$.

\section{Grow Health-Giving "Greens"}

Spinach and allied plants grown for boiled "Greens" are nourishing, and they provide food elements which cannot be obtained readily otherwise. They possess great medicinal value, also, in assisting digestion and enabling the functions of the body to perform efficiently. The following vegetables are among those which furnish boiling greens and they should have a place in every garden.

Beet-tops Southern prize Turnip Seven-Top Turnip

Brussels Sprouts Kale D W F. Rape

Cabbage Mustard Spinach

Collards New Zealand Spinach Swiss Chard

For Garden Pests and plant diseases, the use of insecticides, etc., is imperative. For Liquids, Dust compounds, Sprayers, etc., see pages 54,55 and 56 . 


\section{KALE, or BORECOLE}

One ounce will produce about 1500 plants. Sow 8 pounds per acre broadcast; 4 to 5 pounds in drills.

Spring or Smooth Kale may be sown either in the spring or fall, making greens earlier than the winter sorts. Make spring sowings in February and March. The Siberian and Sootch are the popular sorts for fall sowings. Sow from Aurust 15 to November 15, either broadcast or in drills 18 inches apart and give some cultivation, and they will yield greens throughout the winter.

Spring, or Smooth. Hardy, nuick-growing; best for spring sowing. Sow 10 pounds to the acre broadcast or 4 to 5 pounds in drills. Plt. $10 \mathrm{cts}$. 0 . $15 \mathrm{cts} .1 / 4 \mathrm{lb}$. $30 \mathrm{cts} ., 1 \mathrm{~b} .65 \mathrm{cts}$., postpaid. 5 lbs. at $50 \mathrm{cts}$. $1 \mathrm{~b}$.

Early Green Curled Siberian. Blue Kale or Dwar German Greens. It comes at a time when a variety for the table is scarce, furnishing a valuable whole some food rich in mineral salts, iron, etc. Pkt. $10 \mathrm{cts.}$ oz. $15 \mathrm{cts} .1 / 4$ lb. $35 \mathrm{cts}$., lb. $\$ 1.15$, postpaid. By express, $\$ 1.15$ per lb., 5 lbs. and over, $90 \mathrm{cts}$. per lb.

Green Curled Scotch. Very popular for shipping Light Green; nicely curled. Sow 5 pounds to the acre. Pkt. $10 \mathrm{cts} ., 0 z .15 \mathrm{cts} ., 1 / \mathrm{s}$ lb. $30 \mathrm{cts} ., 1 \mathrm{lb} . \$ 1.00$, postpaid 5 lbs. not postpaid, at $90 \mathrm{cts}$. per lb.

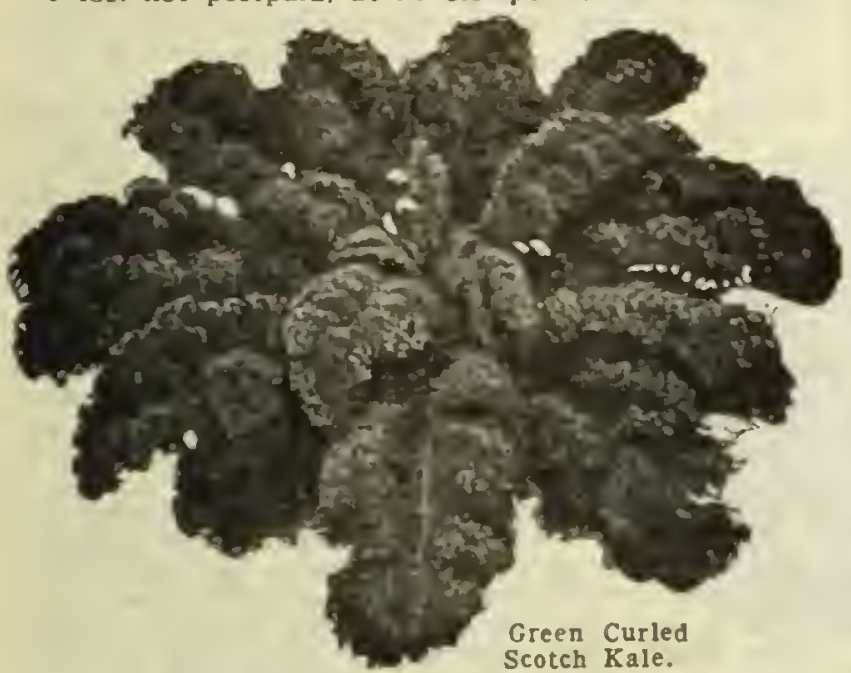

\section{MUSTARD}

One ounce will sow about 75 feet of drill.

Mustard can be grown at almost any time of the gear. Sow the seed elther broadeast or in drills about 1 soot apart. Requires little or no cultivation.

Southern Giant Curled. It grows rapidl. and produces an abundant crop of "greens" or salad. The leaves are large and curled. Plit. 10 cts., oz. 15 cts.. lí lb. $40 \mathrm{cts} ., 1 \mathrm{~b} . \$ 1.00$, postpaid. $5 \mathrm{lbs}$. at $85 \mathrm{cts}$

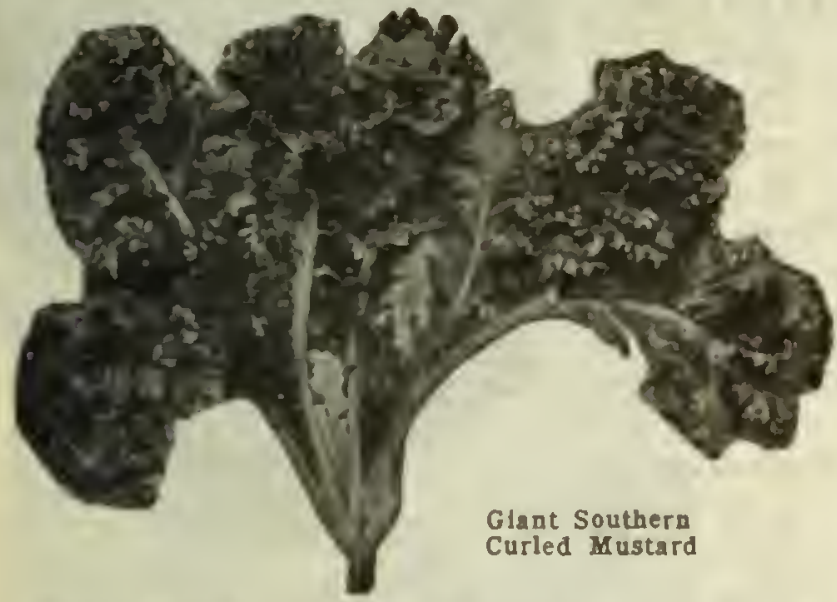

Ostrich Plume. Delicious as well as ornamental. The leaves resemble ostricl plumes. J'kt. $10 \mathrm{cts}, \mathrm{cz} .15 \mathrm{cts}$. lb. $\$ 1.00$, post paid.

Chinese Broad-Leaved. Makes a large and tender growth for green, without bitter taste, Ready six weeks from sowing; sweet and pungent. Pkt. $10 \mathrm{cts}$. oz. 15 cts., 1/2 lb. 65 cts., Ib. Si.00, postpaid.

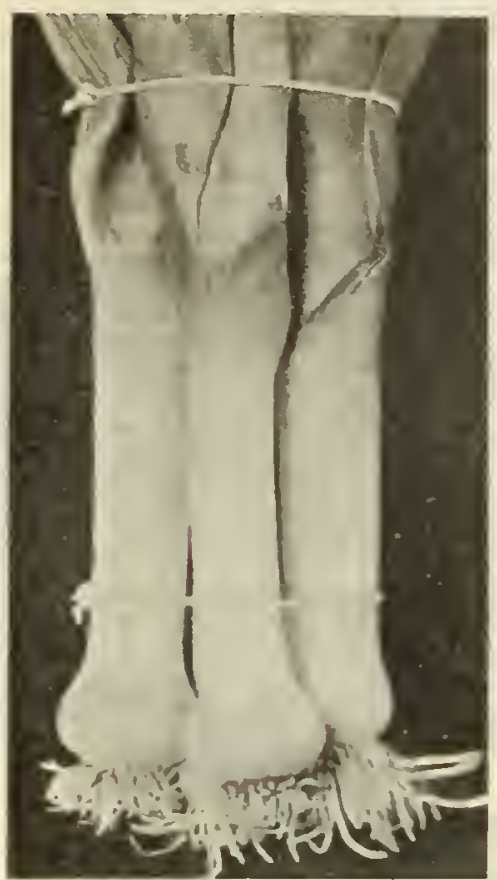

Large Flag Leek.

\section{LEEK}

One ounce will sow 100 feet of drill

Similar to onions in flavor, being of the same family of plants. but does not form a thick bulb. Sow seed early as possible, half an inch deep, and when plants are large c nough to handle transplant to rows 12 inches apart, setting plants 6 inches apart. Hill up as they grow to bleach the stems. or plant in a trench like celery and fill in as tliey grow. Seed inay also be sown in September and trans. planted in spring.

Large Flag. WVell known and popular variety; hardy. Pkt. 10 cts., oz. 25 cts. 1.1 11). 60 cts., 1b. $\$ 2.00$, postpaid

\section{KOHLRABI}

One ounce will sow 200 feet of drill.

A peculiar vegetable, bclonging to the cabbage family and forming a turnip-shaped bulb above the ground which is used in the same manner as turnips. For garden cultivation give same treatment as cabbage. The plants are ready to use in 60 days.

Early White Vienna. Light green, fine grained bulb: sliort leaves.

Early Purple Vienna. Same as abovc, except in color. Pkt. 10 cts.. 0z. 25 cts.. ' 1 lb. 75 cts.. 16. $\$ 2.35$, postpaid.

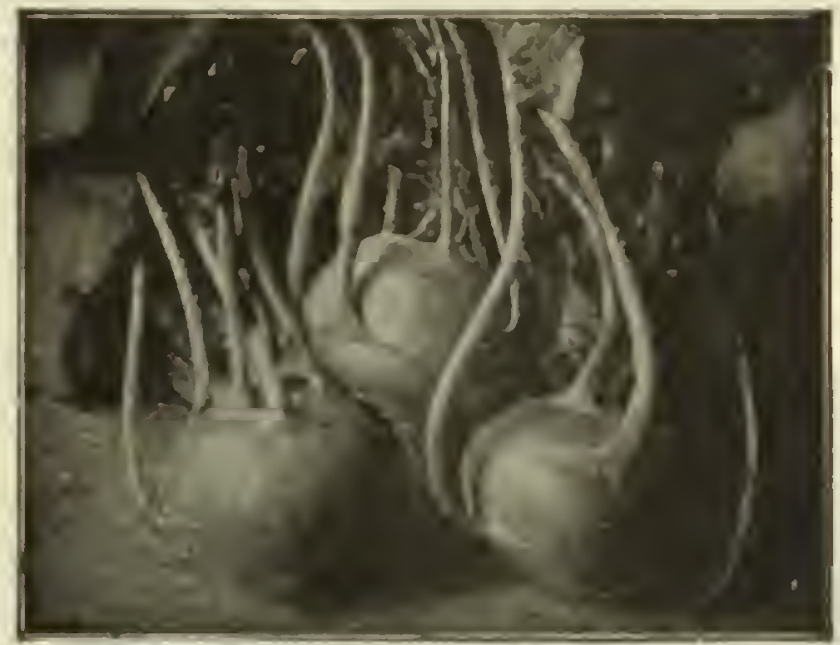

Kohl Rabl

\section{Succession Crops}

Early beets followed by celery. Early beans followed by turnips. Lettuce or onion sets followed by tomatoes. Radishes followed by tomatocs.

Spinach. lettuce or radishes followed by cabbage. Early peas followed by peppers, esgplants or tomatoes.

Tobrcco Dust. 1 lb. 10 cts., 5 lbs. 10 cts., 25 Ibs. $\$ 1.50$, 100 lbs. $\$ 5.00$

Bug Death. 1 lb. 25 cts., 3 lbs. 50 cts., 5 lbs. 80 cts. 
IC] TCE READY TO CUT II

45 TO 85 DAYS

One ounce will produce 2,500 plants; 8 ounces enough plants to set out an acre

To raise the best of Lettuce, rich soil with plenty of humus is needed, and we particularly recommend that it be planted after clover, whenever possible. North Carolina truckers treat the head varieties in the same way as cabbage, sowing the seed the last week of September in beds $1 / 8$ inch deep, and setting the plants in the open field during November. Shelter from the wind is of such immense advantage that if no natural windbreaks are available it pays handsomely to provide artificial ones made from cornstalks or cheap lumber. For the family garden, seed may be sown as late as October in a warm, sheltered bed, protecting it during severe weather with a covering of straw, or it may be transplanted into coldframes to head during the winter. For a succession, sow in beds from the last of March to the middle of May, covering the seed thinly as directed, but taking care to firm the suriace.

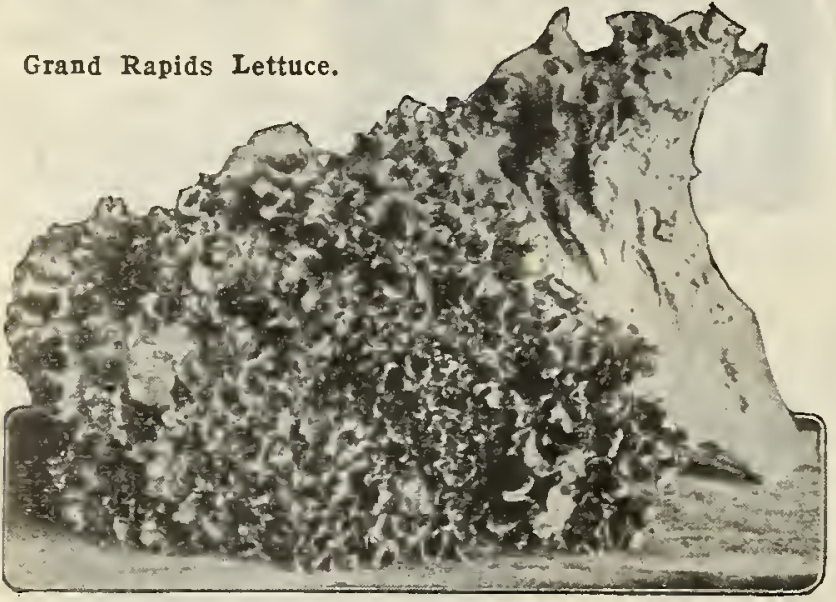

Grand Rapids. Of highest merit as a forcing variety. Pkt. 10 cts., oz. 25 cts., $1 / 4$ lb. 60 cts., lb. $\$ 1.50$, postpaid. Early Curled Simpson. A Jeading early sort; heads up loose and very tender. Pkt. $10 \mathrm{cts}$, oz. 20 cts., $1 / 4 \mathrm{lb}$. $50 \mathrm{cts}$., 1b. $\$ 1.50$, postpaid.

Big Boston. Very popular for outside culture as well as cold frame forcing. The heads are large and compact; leaves broad, almost smooth, but wavy at the edges: color light green, slightly tinged reddish brown. Pkt. $10 \mathrm{cts}$, oz. $25 \mathrm{cts}$., $1 / 4$ lb. $60 \mathrm{cts}$., lb. $\$ 1.65$, postpaid 5 lbs. at $\$ 1.50,10$ lbs. at $\$ 1.35$.

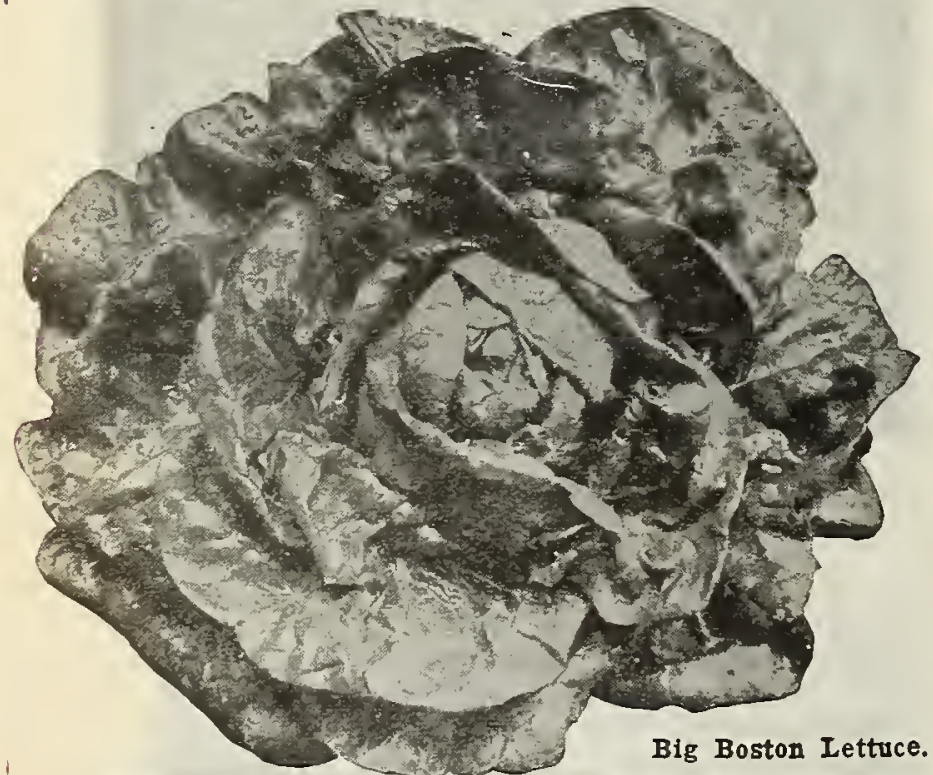

We would call special attention to our lists of Farm Seeds, including Grasses, Clovers, Alfalfa, Wheat, Oats, etc., which will be found further on in this catalog. These are all of the very highest quality, and we heartily recommend them to our farmer friends.

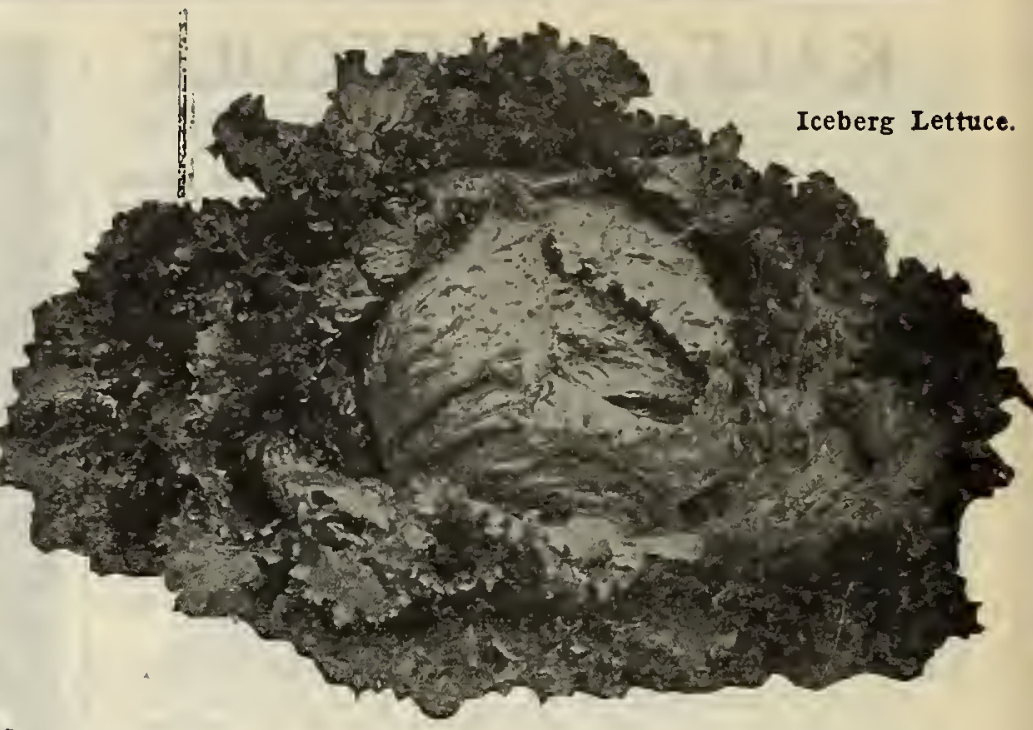

Improved Hanson. One of the best summer Lettuces. Large solid, sure header, crisp and tender. Pkt. $10 \mathrm{cts}$. , oz. 20 cts., $1 / 4$ lb. 60 cts., lb. $\$ 1.75$, postpaid. 5 lbs. at $\$ 1.50$.

Iceberg. A large solid-headed very crisp kind, the hearts of which under moderate cultivation weigh from 2 to 3 pounds. Pkt. $10 \mathrm{cts}$., oz. 25 cts., $1 / 4$ lb. 75 cts., 1 b. $\$ 2.50$.

Wayahead. It is not only earlier than May King and other fine early varieties, but the tightly folded heads are generally larger in size. The outer leaves are a rich, buttery yellow. Wayahead stands a longer time before running to seed than any other early head variety. Pkt. 10 cts., oz. 25 cts., $1 / 4$ lb. 65 cts., lb. $\$ 2.00$, postpaid.

Mignonette. A solid header; leaves broad, excessively blistered, crumpled, and twisted. The best variety for the Southern home-garden. Quality excellent, tender, crisp and sweet. Pkt. 10 cts., oz. 25 cts., 1/4 lb. 65 cts., lb. $\$ 2.25$, postpaid.

New York Improved. Also called "Los Angeles" and "Wonderful." Plants of extra large growth, producing closely folded heads of immense size. The inner portion is beautifully blanched; outer leaves a deep, rich green. Pkt. 10 cts., oz. 25 cts., $1 / 4$ lb. 75 cts., lb. $\$ 2.50$, postpaid.

White Paris Cos. One of the best celery Lettuces. Forms large, light green, solid, well-folded head; of upright growth, and esteemed for its crispness and mild flavor. Pkt. $10 \mathrm{cts}$., oz., 25 cts., $1 / 4$ lb. 65 cts., 1b. $\$ 2.00$, postpaid.

T e n $\mathbf{n}$ is Ball.

Black Seeded. One of the best standard sorts. Pkt. 10 cts., oz. 25 cts., $1 / 4$ lb. $65 \mathrm{cts}, 1 \mathrm{~b}$. $\$ 2.00$.

T e $\mathbf{n} \mathbf{n}$ is Ball. White Seeded. (Boston Market). A good forcer. Pkt. 10 cts., oz. 25 cts. $1 / 4$ lb. $65 \mathrm{cts}$. lb. $\$ 2.00$.

White Summer $C$ a b b a $g$ e. Gree n, very hardy, popular. Pkt. 10 cts., oz. 20 cts. $1 / 4 \mathrm{lb}$. $50 \mathrm{cts}$. ib. $\$ 1.50$.

Un rivalled. A light green strain of Big Boston. Pkt.

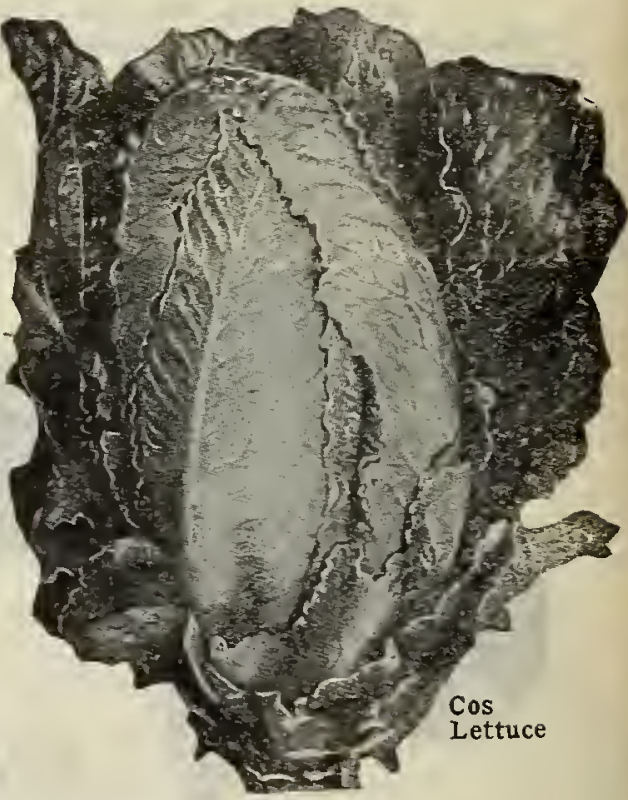

10 cts., oz. 20 cts., 2 oz. 35 cts., $1 / 4$ lb. 50 cts., lb. $\$ 1.60$.

\section{Beet-Tops}

Be sure to sow a row of Beet seed for "Tops." Nothing is more delicious than Beet Tops cooked like spinach when young, and served in same way. Eclipse is good for this purpose. Sow thickly. 


\section{CANTALOUPE, or MUSKMELON}

One oz. will plant 50 hills; 2 pounds to the acre Propare blls 4 to 6 feet apart in a rich, moderately dry, sandy soll, using well-rotted manure. When danger of frost is over, plant ten to twelve seeds in each hill, and when well up, thin out, leaving four strong plants to the hill. Give frequent but shallow cultivation till the fines cover the ground. Dust with sifted ashes, air-glaked lime or road-dust to keep off insects; spray with the gield. Do not grop near cucumbers, squashes, etc. Matures in about 90 days.

Honey Dew. Finest extra late variety. Very popular Melon with a delicious honey flavor. smooth light cream colored skin. with thick flcsh of light green color. Melons weigh 6 to 8 lbs. when matured. Pht. $10 \mathrm{cts..} 0 z .15 \mathrm{cts} ., 1 / 4 \mathrm{Ib} .45 \mathrm{cts}$. . Ib. \$1.35. postpaid.

Genuine Rocky Ford Netted Gem. The fruit is small, almost round, smooth, showing no rib. and densely covered with heavy gray netting. Flesh thick and dccp green, showing a faint lining of pink or gold at the ccnter: of the highest quality. Pkt. $10 \mathrm{cts..} \mathrm{0z.} 15 \mathrm{ct} 9 ., 1 / 4 \mathrm{Ib} .45 \mathrm{cts.}$ Ib. $\$ 1.00,10$ lbs. $\$ 9.45$ post paid.

Montreal Market. Fruit of the largest size, often attaining a weight of fifteen to twenty pounds. Shape nearly round. flattencd at the ends, deeply ribbed: flesh remarkably thick. green. melting. and of the finest flavor. Pkt. $10 \mathrm{cts} ., 02.20 \mathrm{cts.}$. 1/4 lb. $60 \mathrm{cts.,} \mathrm{lb.} \$ 2.00$.

Banana. Long. shaped like a banana; has a most iclicious odor. Pli. 10 cts., 0z. 20 cts., $1 / 4$ lb. 45 cts.. lb. 51.50 . post paid.

Delleious Gold-Lined Rocky Ford. Its shape is ideal, vcry slightly oval, no ribs, and is heavily nctted over entire melon. The mclon is thick-meated, finc grained and swcct; color green. with gold margin ncxt to the secd ravity. Pkt. $10 \mathrm{cts.}, 0 z .20 \mathrm{cts.}$ 1/4 Ib. 40 cts., Ib. $\$ 1.25$, post paid.

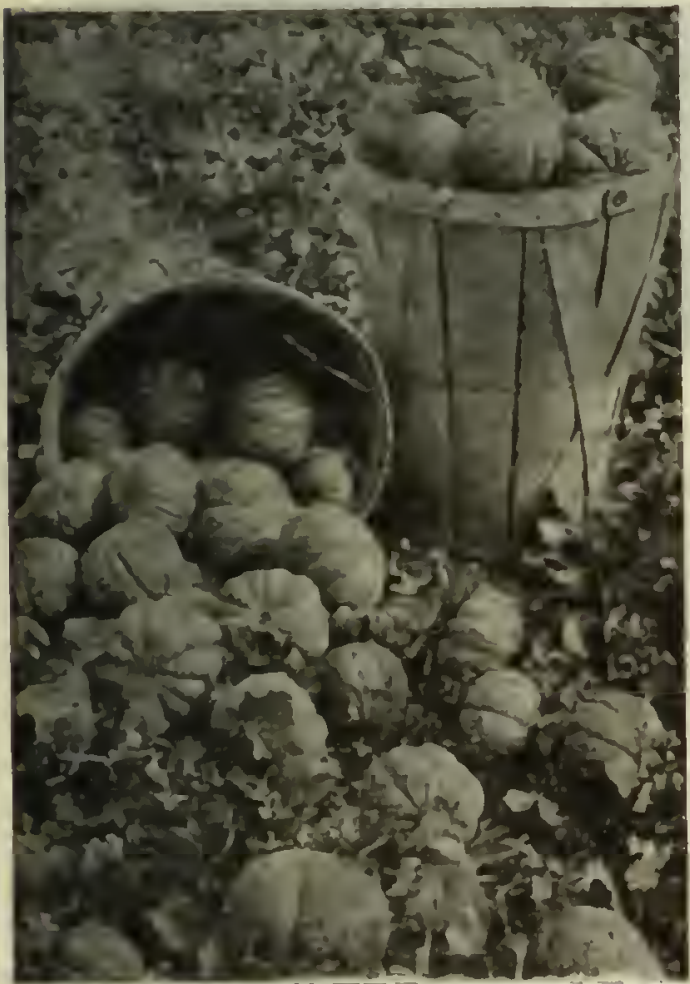

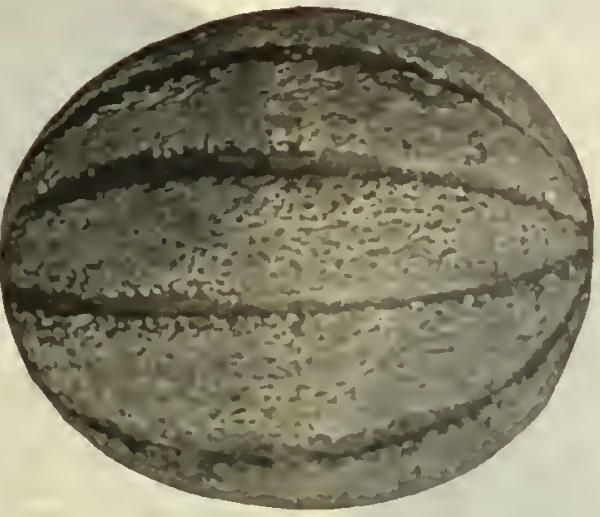

Knight Cantaloupe.
Knight. About a week earlier than the Rocky Ford: of uniform size. with thick. green flesh, of splendic flavor and appearance. Pkt. 10 cts.. Oz. $15 \mathrm{cts} .1$ lb. $40 \mathrm{cts} ., 1 \mathrm{lb}$. $\$ 1.25$. postpaid.

Hoodoo. As a Muskmelon for the private garden, this variety will surcly please all who plant it. The vines make a strong and vigorous growth. which enables them 10 withstand disensc and producc an abundant crop of the most delicions melons one can imaginc. Flesh thick and firm; deep salmon or orange color. Pkt. $10 \mathrm{cts} ., 0 z .15 \mathrm{cts}$. ti th. 40 ct... 1b. \$1.50. $51 \mathrm{lbs}$. at \$1.25.

Enerald Gem. Dark grecn skin. orangc flesh, very swcet, extra carly. Pkt. $10 \mathrm{cts.}$ oz. 20 cts. 1.1 Ib. 50 cts.. Ib. $\$ 1.25$.

Fordhook. Flcsh thick, salmon. Pkt. $10 \mathrm{cts.,} \mathrm{oz..} 20 \mathrm{cts.}$ if lb. $50 \mathrm{cts..} \mathrm{lb.} \$ 1.50$

Eden Gem. The real true moncy-makins varicty for the shlpper and market gardener as wcll as the most satisfactory of all for home use. Its dense ncting helps ercatly in resistance to inscct attacks. Pkt.

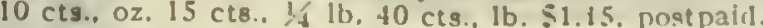

Tip Top, Shumwaya Glant, Edwards New Pcrlecto and Pollock Musk . melons. Sce pagc 3 .

\section{Extra Early Macken-} sack. An early mclon. fattence at the end, roughly netted. thick flesh and of cood flavor. Pkt. I0 cts.. oz 15 cts.. $1 / 4$ 40 cts. lb. $\$ 1.00$. postpaid.

Hearts of Gold. A wonderful ncw Mclon of cxccllent flavor and quality. l'kt. 10 ct.9. 1/ lb. 45 cts. lb. $\$ 1.50$.

Osag*. Salmon fleslyed. delicious. Pkt. $10 \mathrm{ctg} . .1 / 4$ lb. $45 \mathrm{cts}$. 1b. $\$ 1.50$.

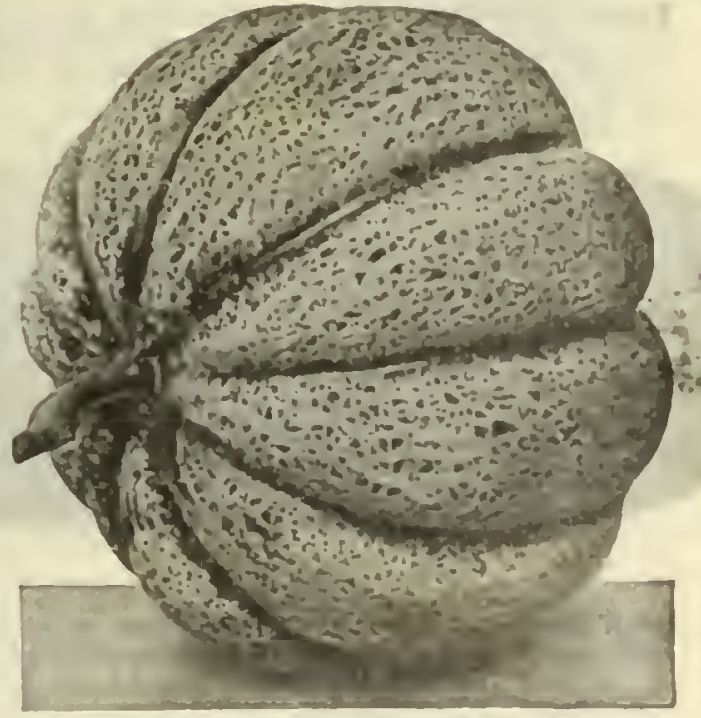

Extra Early Hackensack.

Eden Gem.

Melon Pests Watch out for the cutworms, aphis and blight. Use Paris 


\section{WATERMELON}

A rich but light and well-drained soil is needed to produce the best results. Plant the seeds 1 inch deep, from April to July, in hills not less than $\sigma$ feet apart each way. Avoid planting until the warm weather has become settled, as the vine will never thrive if checked by cold, and it really pays to use the seed more lavishly than indicated above. After the first plowing, cultivation must be shallow and the crop "laid by" as soon as the ground is well corered. Matures in about 110 days.

Carolina Bradford. Fine flavored, large shipping melon, oblong in shape, rather square ends. The skin is very darkgreen with darker stripes; flesh is very tender and solid. Pkt. 10 cts., oz. 15 cts., $1 / 4$ 1b. 40 cts., 1b. $\$ 1.25$, postpaid.

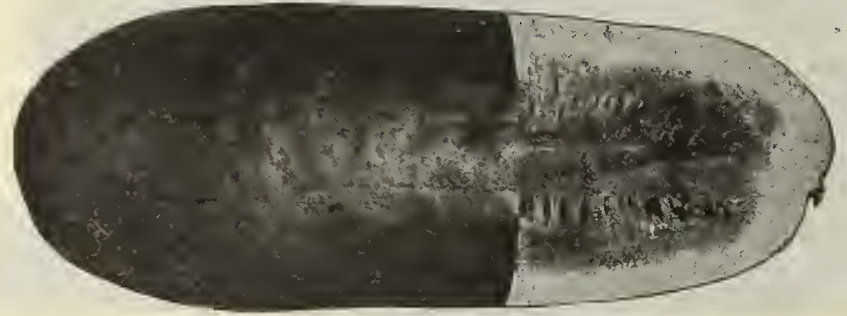

Improved Kleckley Sweet.

Improved Kleckley Sweet. No other melon has ever attained such popularity for home use and nearby markets. This is a perfect melon for that purpose. Its eating qualities leave nothing to be desired. Vines strong and vigorous; melons medium to large in size. Oblong. The melons grow 18 to 24 inches in length; 10 to 12 inches through. Skin a very rich, dark green color; white seeds. Pkt. $10 \mathrm{cts} ., \mathrm{oz} .15 \mathrm{cts} ., 1 / 4 \mathrm{lb} .25$ cts., lb. 90 cts., postpaid.

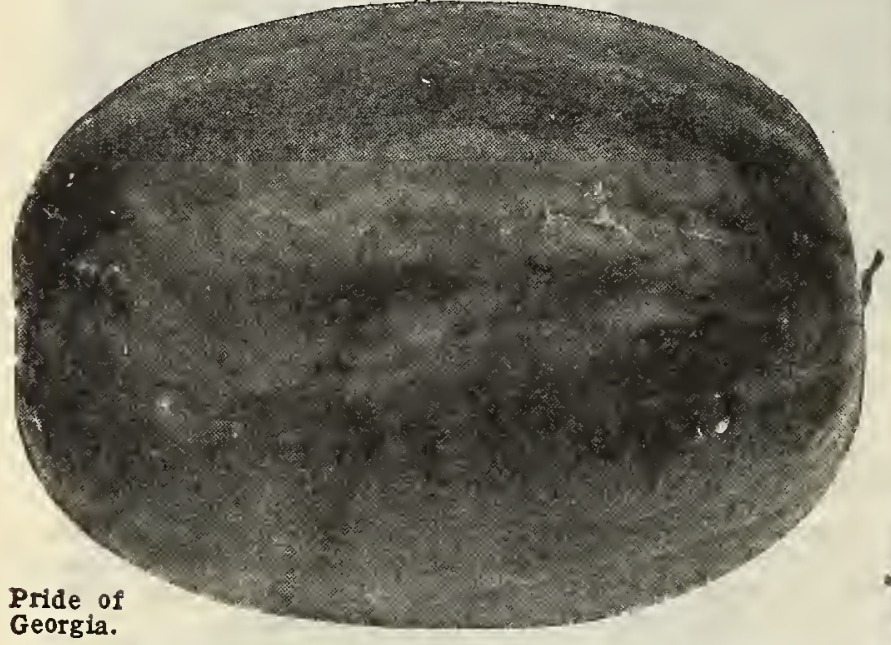

Pride of Georgia. One of the largest melons in our list. Dark green rind; oval shape; meat bright red. Pkt. 10 cts., oz. 15 cts., $1 / 4$ lb. 25 cts., lb. 90 cts., postpaid. 5 lbs, 75 cts. $1 \mathrm{~b}$.

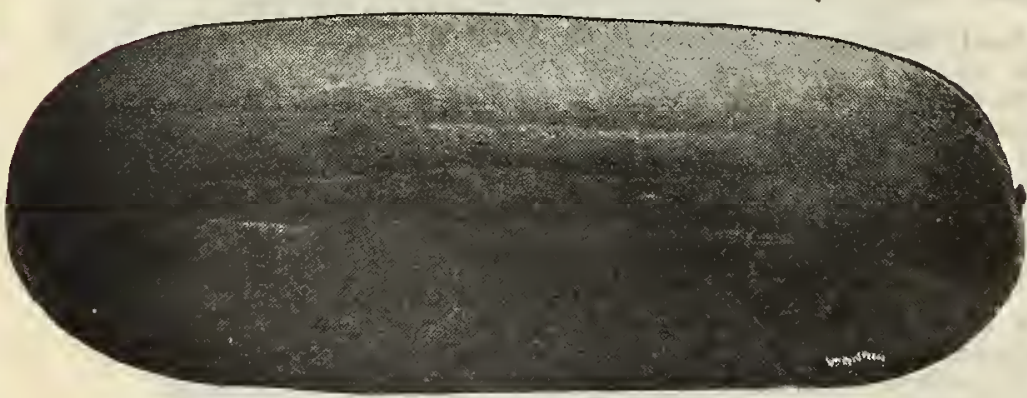

Irish Grey.

Irish Grey. A mottled greenish grey, every melon very distinct. A fine shipper and the equal of any in sweetness and quality. Pkt. $10 \mathrm{cts.}, 0 z .15 \mathrm{cts} ., 1 / 4 \mathrm{lb} .40 \mathrm{cts}$., 1b. $\$ 1.25,5$ lbs. $\$ 5.00$.

Seeds and Plants for the Garden ing in flats or frames and also for use outdoors as ounce is sufficient for a row 100 feet in hills:

2 to 3 pounds will plant an acre in hills

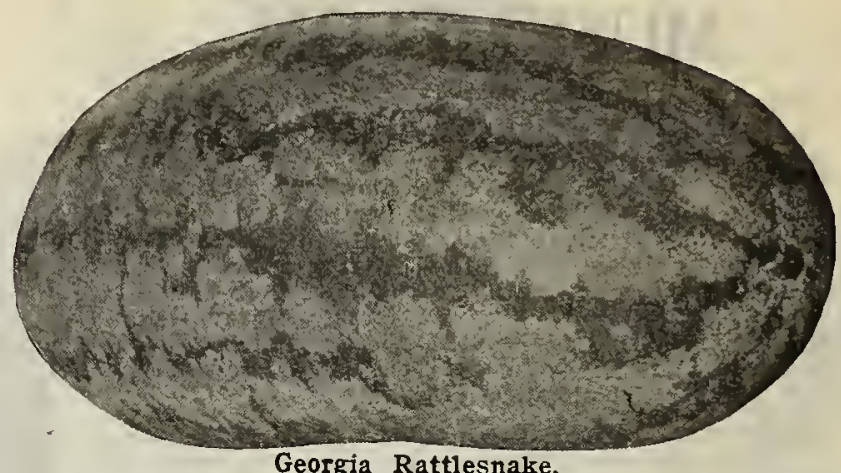

Georgia Rattlesnake or Gypsy Striped. Oblong. striped and mottled; very sweet; popular South. Pkt. 10 cts., oz. 15 cts., $1 / 4$ lb. 30 cts., lb. 90 cts., postpaid. 5 lbs. 75 cts $1 \mathrm{~b}$.

Dark Icing. An extra early and extra good melon for home use and nearby market. One of the most delicious fruits of round or shortened oval form, with dark green skin. Flesh deep pink, very sweet and melting. White seed. Pkt. 10 cts., oz. 15 cts., 1/4 lb. 25 cts., 1b. 90 cts. postpaid. 5 lbs. 75 cts. $1 \mathrm{~b}$.

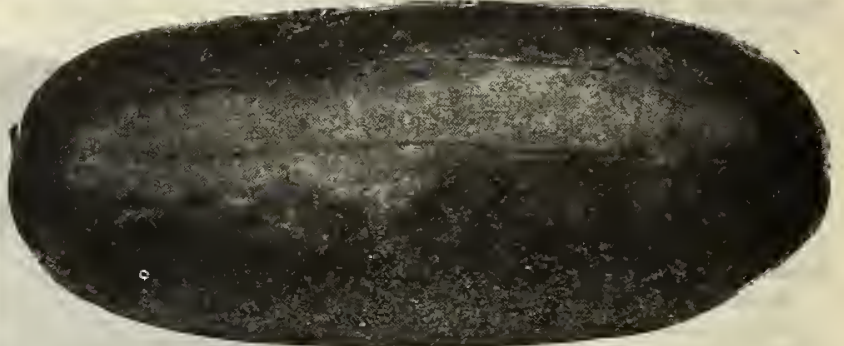

Halbert Honey.

Halbert Honey. A variety somewhat similar to Kleck ley Sweets- of much darker color. Pkt. $10 \mathrm{cts}$., oz. 15 cts., $1 / 4$ lb. 35 cts., 1b. $\$ 1.00$.

Duke Jones, or Jumbo. Although a shipping melon, it is of such good quality and fine flavor that it is equally well recommended for home use. Extra large and of attractive color and appearance. Pkt. $10 \mathrm{cts}$, oz. 15 cts., $1 / 4$ lb. 25 cts., lb. 90 cts., postpaid.

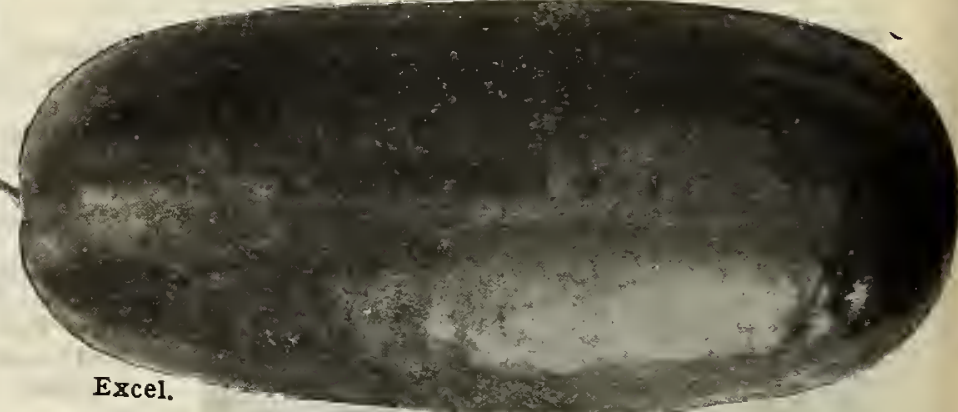

Excel. It is well adapted to Southern conditions, and as a shipping melon it can't be beat. "The rind is tough and will withstand the roughest use in transit. A heavy cropper. It is large, long dark green melon with faint stripes." Flesh red, very crisp, solid. Pkt. 10 cts., oz. 20 cts., $1 / 4$ lb. 40 cts., lb. $\$ 1.15$, postpaid.

The Jackson. An old variety, but still popular in many sections. Early; long pale green melons; very tender; crimson flesh; unusually sweet. Pkt. $10 \mathrm{cts.}$ oz. 15 cts., 1/4 lb. 30 cts., lb. 90 cts., postpaid.

Florida Favorite. Oblong, of fair size. Rind tough, dark green, irregular stripes; flesh bright red, fine quality. Pkt. $10 \mathrm{cts}$., oz. 15 cts., $1 / 4$ lb. 30 cts., lb. $90 \mathrm{cts}$. , postpaid.

Tom Watson (see inside back cover). There's delicious sweetness in every bite. The flesh is rich red, crisp and tenderly melting. Pkt. $10 \mathrm{cts}$., oz. $15 \mathrm{cts} ., 1 / 1 \mathrm{lb} .35$ cts., 1b. $\$ 1.00,5$ lbs. $\$ 4.25,10$ lbs. $\$ 7.75$.

Vegetable seeds should be ordered in advance of the time for planting in the open, so that they will be on hand in time for plantsoon as weather and condition of the soil make planting possible. 


\section{OKRA, or GUMBO}

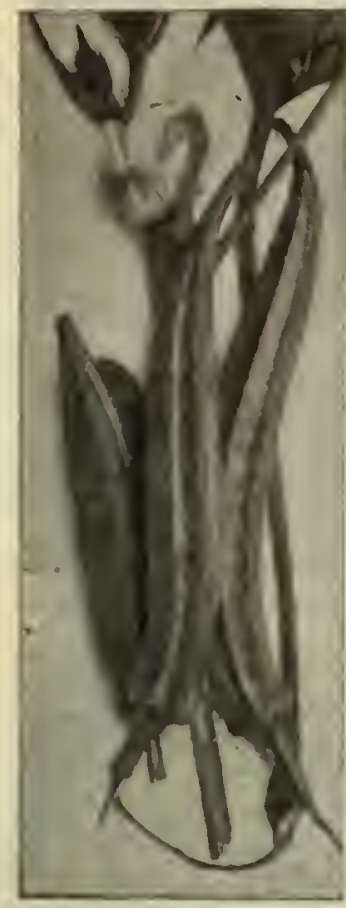

Perkins

Mammoth Podded

\section{PARSNIPS}

One ounce will sow aboul 100 feet of drill.

Sow seed during the eariy spring in a rich soil, driliing them in rows from 2 to 3 feet apart, and not over 1 lacb deep. Later thin plants to 6 lnches apart, and glve frequent shallow cultiration.

Long, Smooth, or Hollow Crown. The best variety for table use and for the market. Eariy and productive. Roots long, smooth and tender. Pkt. 10 ets., 0z. 15 cts., $1 / 3$ lb. 35 cts., 1 b. 95 cts., post paid.

The SAVO Steel All-year-round Flower Box

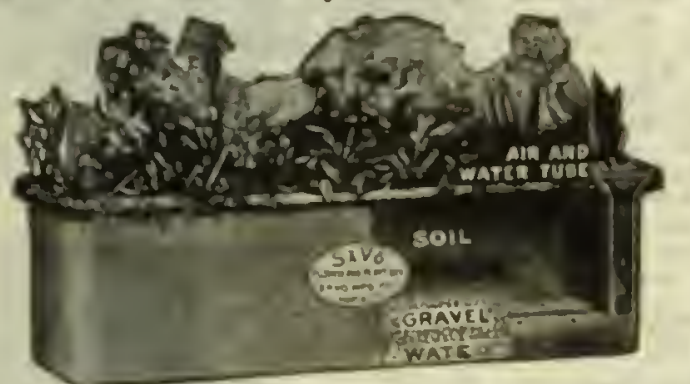

Self-Wubering and Sub-Irrigating for Porches. Swn Parlors, elc. Perfect Air Circulation and Drainage, Leak Proof and Rust Proof.

\section{Most Efflelent, Durabie and Artistic.}

Six Sizes. Beoulifully Finished.

Fill with water only once a weck. Move Savo Boxes indoors or out and you have beautiful Flowers and Plants continually for many years.

\section{An All-Year Round Garden}

Model A- 8 in. high, $91 / 2$ in. wide, 23 in. long $\$ 3.50$

Model B $-8 \mathrm{ln}$. high, $93 / 2$ in. wide. $29 \mathrm{in}$. long 4.00

Model C- $8 \mathrm{in}$. high. $91 / 2$ in. wide. 35 in. long 4.50

Model D- 8 in. high. $91 / 2$ in. wide, 41 in. long 5.00

Model E- 8 in. high, 12 in. wide, 12 in long 3.50

Model F-12 in. hlgh, 12 in. wide, 12 in. long 4.00

Model B fernery, complete box and stand.

$301 / \mathrm{hin}$ hlgh. $91 / 6$ wide, 29 in. long.

Model $G$ round fernery, complete box and

otand $12 \mathrm{in}$. diameter, $28 \mathrm{l} / \mathrm{l} \mathrm{ln}$. hlgh..

$\$ 6.00$

\section{CELLO GLASS CLOTH}

For loot berls, cold frames or plant beds, $15 \mathrm{cts}$. square foot, 50 square fect for $\$ 7.00$. Send for free sample.

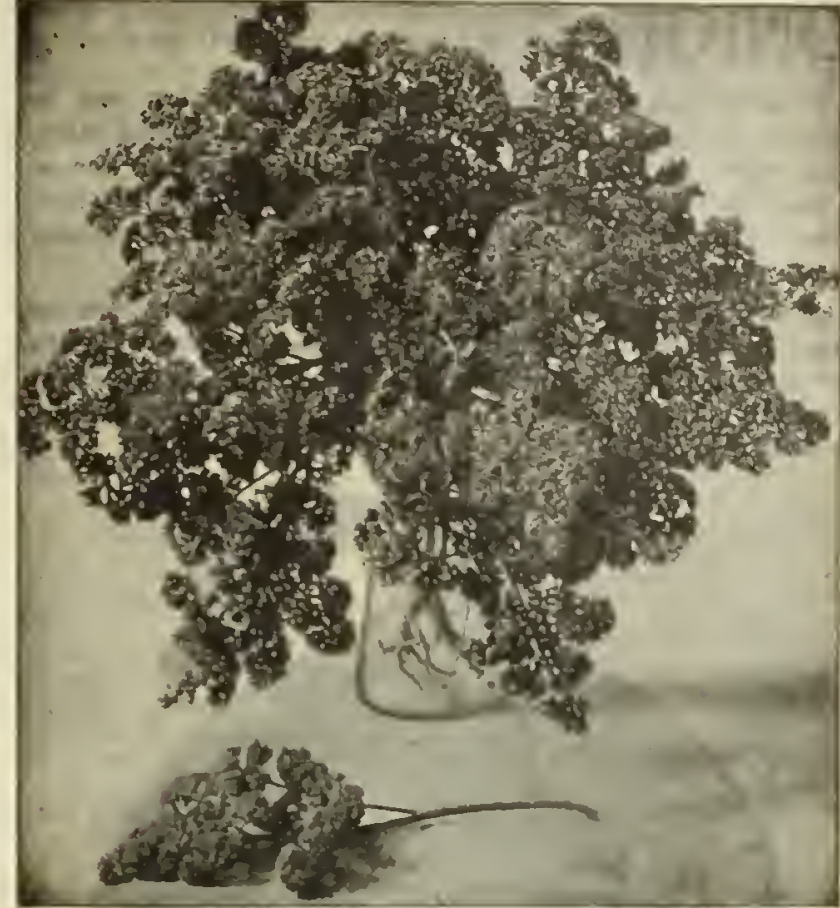

Champion Moss Curied Parsley

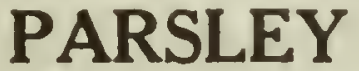

One ounce uill sow a 100-foot drill.

Parsicy is easily grown, onily th takes sereral weeks for it to come up, hence the ground where it is sown is ofter covered with weeds or dug over with the bellef that the seed is no good. Sow it eariy in the spring in rows a foot apart. It can aiso be used to border beds, making a very pretty effect. A few plants can be taken up in the fail ad put in pots or boxes in a sunny window and will continue to furnish ieaves for Davoring or garnishing throughout winter. Champion Moss Curled. A very fine strain, with beautiful foliage, useful for all purposes. Pkt $10 \mathrm{cts}$. oz. 15 cts., 1/4 lb. 40 ct... lb. \$1.00. postpaid.

Plaln. Hardy and vigorous grower; not so mild as the above. Pkt. $10 \mathrm{cts.} 02.15 \mathrm{cts} ., 3$ ib. $25 \mathrm{cts} .1 \mathrm{lb} 75 \mathrm{cts}$.

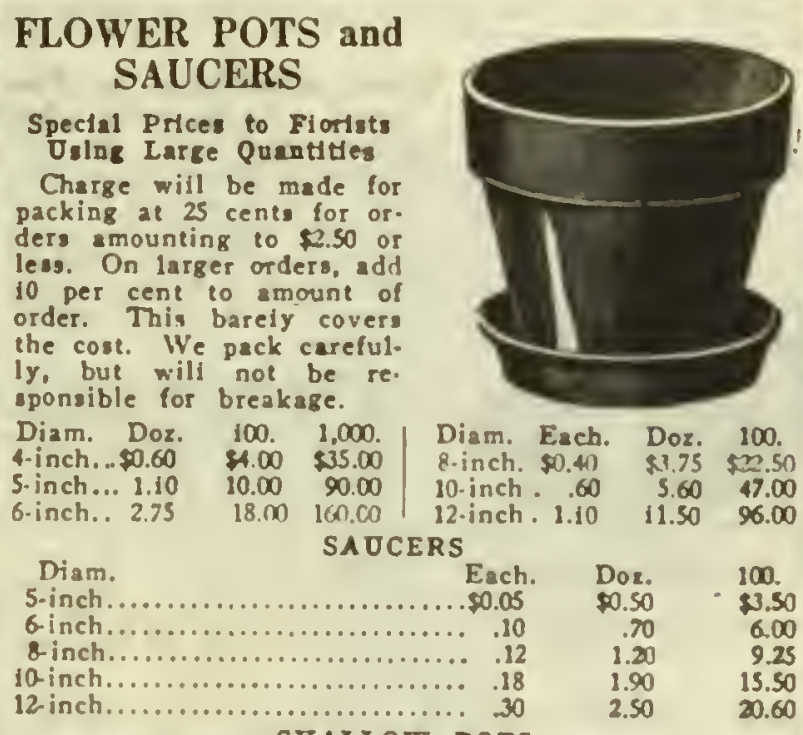

SHALLOW POTS

Similar to the ordinary flower-pot, but shailower be ing only $41 / 5$ to $5 \mathrm{in}$. deep. Just the thlng for bulbs,

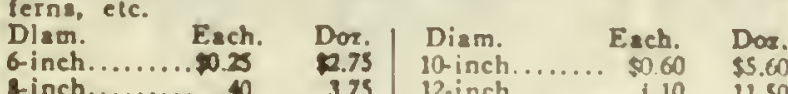

Hinch........ .40 3.75 12-inch........ 1.10 11.50

Ast for prices on sizes not quoted.

SUCCESS FLOWER BOXES

24-Inch sizc . ....\$2.00 36 -inch size.

$30-$ Inch sizc . . . . . 250 42-inch size
5.300 


\section{ONT One ounce will sow abous 100 feet of drill 5 to 6 pounds will plant an acre}

To grow large Onions from seed the first year, sow in January or February in hotbed or in the open ground later, and when the weather opens and the plants are the size of a goose-quill, transplant 4 to 5 inches apart in 12 to 18 inch rows. Transplanting always increases the yleld, sometimes doubles it.

GROWING ONION SETS: To grow Onion Sets, sow in broad wide rows in March or early in April, 40 to 50 pounds per acre and keep clean of weeds. In late summer or whenever the tops die, remove the sets to a dry place spreading them out thinly on trays made of laths.

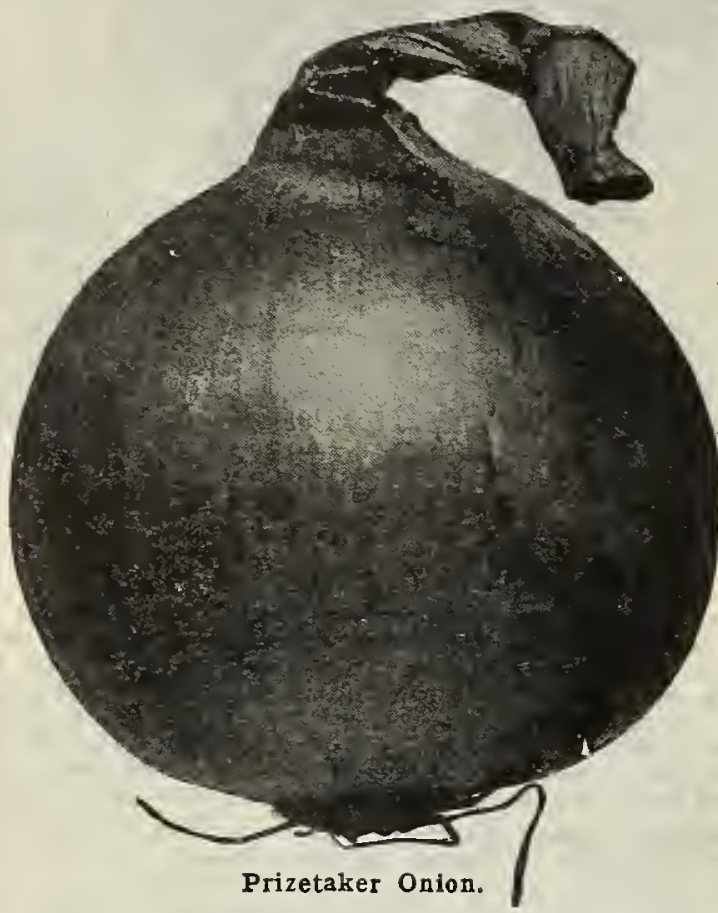

Prizetaker. A large-growing yellowish brown variety. The flesh is white, fine-grained, and like all Spanish Onions, is mild. Pkt. 10 cts., oz. 35 cts., $1 / 4$ lb. $\$ 1.25$, 1b. $\$ 4.50$, postpaid.

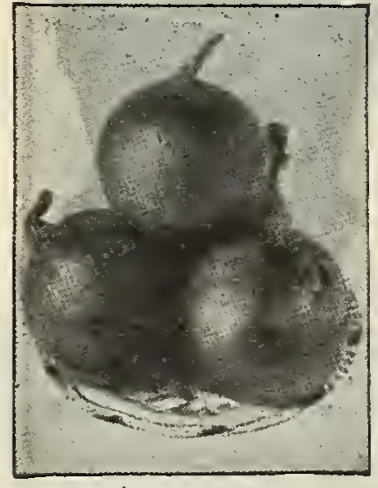

Yellow Globe Danvers.
White Silverskin, or Portugal. Large early white Onion, noted for its mild flavor and good keeping qualities. It is one of the best keepers among the early Onions, and is of ten used for pickles. Pkt. 10 cts., oz. 50 cts., $1 / 4$ lb. $\$ 1.50,1 b . \$ 5.75$. postpaid.

Large Red Wethersfield. The bulbs are large, somewhat flattened, but thick; skin purplish red; flesh purplish white; very hard and solid; an excellent keeper and a heavy cropper. A good Onion for poor and dry soils. Pkt. 10 cts., oz. 35 cts., $1 / 4$ lb. $\$ 1.25,1 \mathrm{~b}$. $\$ 4.50$, postpaid.

Yellow Globe Danvers. It is a great favorite with market gardeners and commercial growers. Very productive and a good keeper. The bulbs grow large, of globe shape and have a clear yellow color. The flesh is crisp and mild. Pkt. 10 cts., oz. 35 cts., 1/4 lb. $\$ 1.25,1 \mathrm{~b}$. $\$ 4.50$, postpaid.

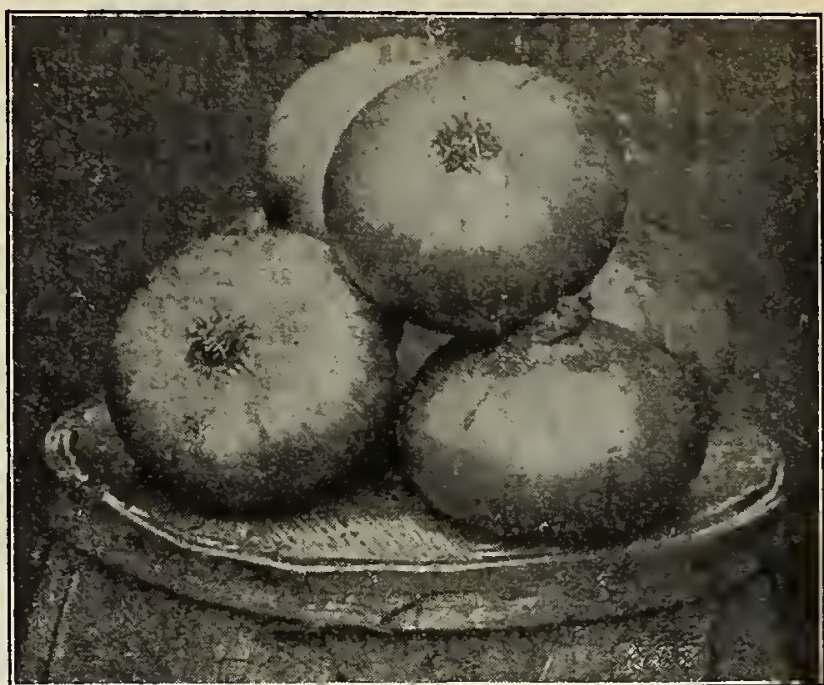

Extra Early White Pearl.

Extra Early White Pearl. The quickest of the white sorts; makes large pearly white Onions, tender, mild and of excellent flavor. Sown in the spring thickly, and the sets put out in the fall, large Onions may be had befor any other sorts are ready. Pkt. $10 \mathrm{cts}$., oz. $50 \mathrm{cts.}$ $1 / 4$ lb. $\$ 1.50,1 b$. $\$ 5.00$, postpaid.

\section{Onion Sets}

\section{Bushel prices quoted on request.}

CULTURE OF

ONION SETS

Sol 1 require. ments the same

as for Onion

seed. Place the

Onion Sets 3 to

4 inches apart, according to the size, 2 inches deep, in rows foot apart. It

is customary to

is customary to furrow out the soll with a little hand plow or

hoe. Set the

Onion in this

furrow $r$ ig ht

side $4 \mathrm{p}$ and cover with a garden rake and if the soil is dry it should be well firmed over the sets; 250 to

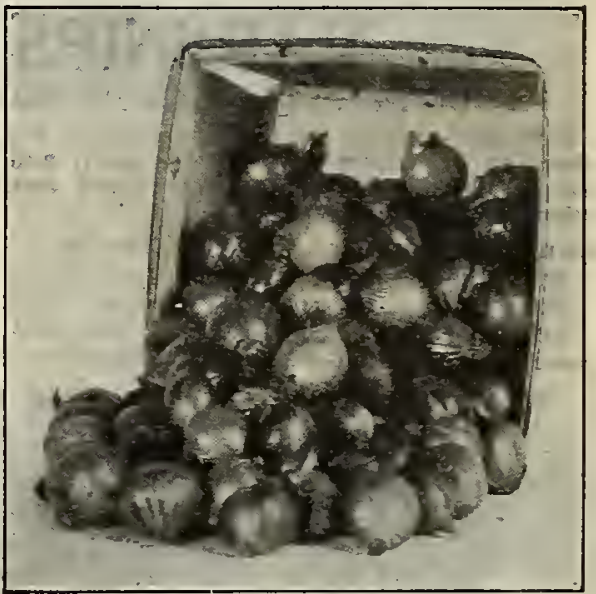

Onion Sets.
300 lbs. of sets required for one acre. One pound equals. about one quart.

Silverskin. Lb. 25 cts., (postpaid, $35 \mathrm{cts}$ ) , $5 \mathrm{lbs} .85 \mathrm{cts}$. 10 lbs. $\$ 1.50,1$ bus. 32 lbs. $\$ 4.00$.

Fellow Danvers. Lb. 25 cts., (postpaid, 35 cts.), 5 lbs. 85 cts., 10 lbs. $\$ 1.50,1$ bu. 32 lbs. $\$ 3.75$.

Red Wethersfield. Lb. 25 cts., (postpaid, $35 \mathrm{cts}$ ) . 5 lbs. 85 cts., 10 lbs. $\$ 1.50,1$ bu. 32 lbs. $\$ 3.75$.

Extra-Early White Pearl. Recommended for fall planting. Lb. 25 cts., (postpaid, 35 cts.), 5 lbs. 85 cts., 10 lbs. $\$ 1.50$.

White Multiplier. Qt. 25 cts., pk. $\$ 1.50$

Yellow Potato. Qt. 35 cts., pk. $\$ 1.75$.

Egyptian or Red Perennial. Best for early green onions. Pt. 15 cts., qt. 25 cts., $1 / 2$ pk. 65 cts., 1 pk. $\$ 1.00$, bu. $\$ 3.50$.

Carbon Disulphide. For Ants and Cut Worms, also Grain and Cowpea Weevils. 1 lb. 50 cts., 5 lbs. \$2.25, 10 lbs. $\$ 4.00$. (Cannot be mailed.) 


\section{PEPPER}

One ounce will produce about 1200 plants.

Sow in hothed in Fehruary or March and transplant outside in May, 18 ins. apart, in 2 to 3 foot rows. When the ground hecomes warm, sow outside and transplant is ahove. Cultivate well and keep free of weeds. Fen manure, liquid manure, or a good garden fertllizer, if worked into the soil when the plants are 6 inches high. will materially increase the yield. Matures in about 130 days.

Chinese Giant. This is the largest sweet pepper ever offered. Grows about 2 feet tall, bearing scarlet colored fruit measuring from 12 to 15 inches in circumference and about 5 inches long. Flesh is thick, mild, very tender and sweet. May be sliced and eaten as tomatoes, or stuffed as mangoes. Pkt. 10 cts., oz. 50 cts., $1 / 4$ lb. $\$ 1.50,1 \mathrm{~b}$. $\$ 5: 10$, postpaid. By express, $\$ 5.00$ per $1 \mathrm{~b}$.

Large Bell, or Bull Nose. A beautiful sweet pepper, with large green fruits turning to a vivid scarlet. Very thick flesh, perfectly mild and a heavy yielder. Ripens early. Pkt. 10 cts., oz. 40 cts., $1 / 4$ lb. $\$ 1.50,1 \mathrm{~b}$. $\$ 5.00$, postpaid. By express, $\$ 4.90 \mathrm{lb}$.

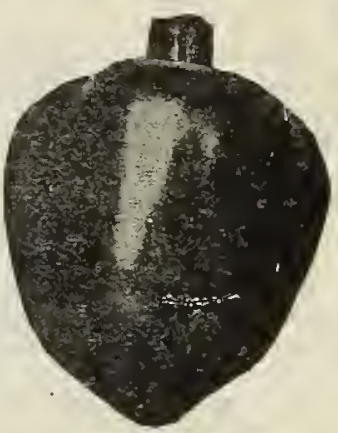

Pimento Pepper.
Pimento. One of the sweetest peppers grown; heartshapec and brilliant red color. Being of a medium size, it is very desirable for filling with meats, etc. May be made into Spanish omelettes and is excellent for canning. Pkt. $10 \mathrm{cts} ., 0 z .40 \mathrm{cts} ., 1 / 4$ lb. $\$ 1.00,1 \mathrm{~b} . \$ 3.50$, postpaid. By express, $\$ 3.40$ per $1 \mathrm{~b}$.

Ruby King. Fruits red. from 4 to 6 inches long by 3 or 4 inches in diameter. Fruit dark green when young, turning to bright red as it ripens. Excellent for pickles. Pkt. 10 cts., oz. 40 cts., $1 / 4$ lb. $\$ 1.00,1 b$ $\$ 3.50$ postpaid. By express, $\$ 3.40$ per lb.

Long Red Cayenne. A long, red, very hot variety. Green and ripe fruits are used for pickling, and ripe fruits dried for winter use. Pkt. $10 \mathrm{cts.,} \mathrm{oz.} 40 \mathrm{cts}$. $1 / 4$ lb. $\$ 1.00$, lb. $\$ 3.75$, postpaid. By express, $\$ 3.65$ per lb.

Neapolitan. Very early and productive; large and sweet; fruit of upright growth, four to four and one-half inches long by two inches in diameter. Pkt. 10 cts., oz. 40 cts., $1 / 4$ lb. $\$ 1.25$, lb. $\$ 4.00$.

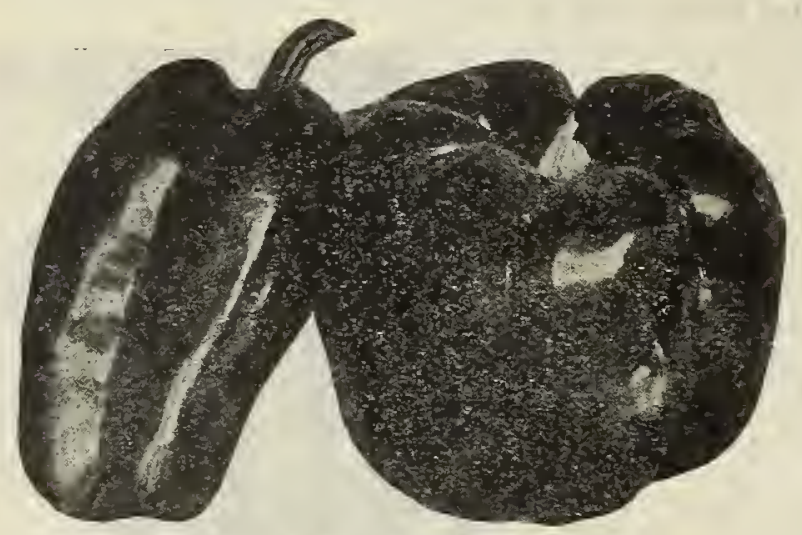

Ruby King and Be1l Pepper.

Golden Queen. Excellent quality. Pkt. 10 cts., 1/2 oz. 30 cts., 1 oz. 50 cts.

Red Chili. Good hot pickling. Pkt. 10 cts., oz. 35 cts., $1 / 4$ lb., $\$ 1.00,1 b . \$ 3.75$, postpaid.

Sweet Mountain. An excellent sort similar to the Large Bell, but larger and sweeter. Pkt. $10 \mathrm{cts.,} \mathrm{oz.} 40 \mathrm{cts} ., 1 / 4$ lb. $\$ 1.00, \mathrm{lb} . \$ 3.25$

\section{PREMIER BRAND PULVERIZED POULTR $Y$}

\section{MANURE}

10 lbs. 75 cts., 50 lbs. $\$ 1.75,100$ lbs. $\$ 3.25$.

\section{PUMPKIN}

One ounce is sufficient for a row of 100 feet in hills; for an acre in hills, 2 to 3 lbs.

Plant from May to July, 1 inch deep in hills 8 feet apart each way, and cultivate frequently until the vines get a strong growth. Matures in 70 to 90 days.

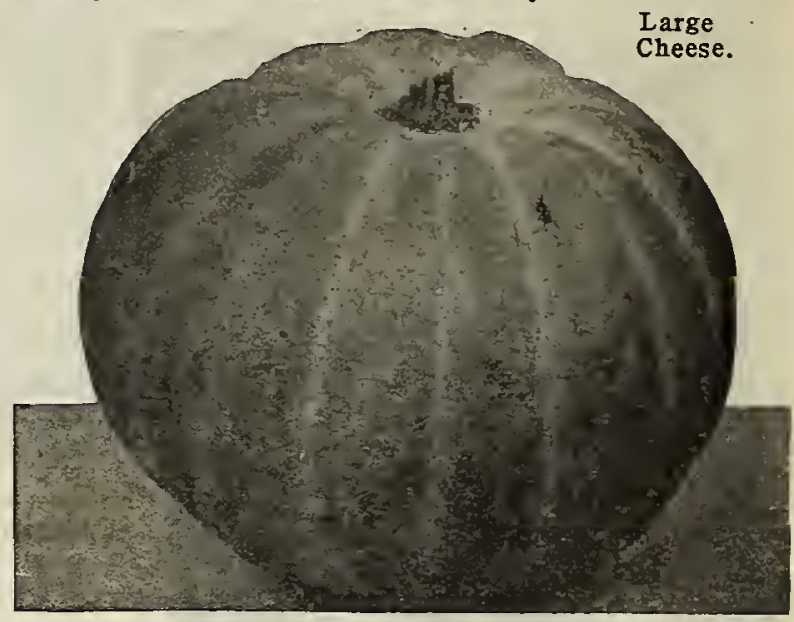

Large Cheese. Produces very large flat ribbed fruit of a beautiful orange red color. A heavy yielder and well adapted for home, market or canning purposes. Pkt. 10 cts., oz. 15 cts., $1 / 4$ lb. 25 cts.. lb. 85 cts., postpaid. By express, 75 cts. per lb.

Sugar or Pie. Flesh deep orange yellow; remarkably sweet, and fine grained. One of the best for pies and a good keeper. Pkt. 10 cts., oz. 15 cts., 1/4 lb. 25 cts., lb. 85 cts., postpaid. By express, 80 cts. per $1 \mathrm{~b}$.

Corn Field Pumpkin. Grown in corn fields principally for stock, but also makes excellent pies. Pkt. 10 cts., oz 15 cts., $1 / 4$ lb. 20 cts., lb. 60 cts., postpaid. By express, $50 \mathrm{cts}$. per lb.

Sweet Potato. Bell-shaped. White flesh. Used for pies. Pkt. $10 \mathrm{cts}$. oz. 20 cts., 2 oz. 35 cts., 1/4 lb. 50 cts., lb. $\$ 1.60$.

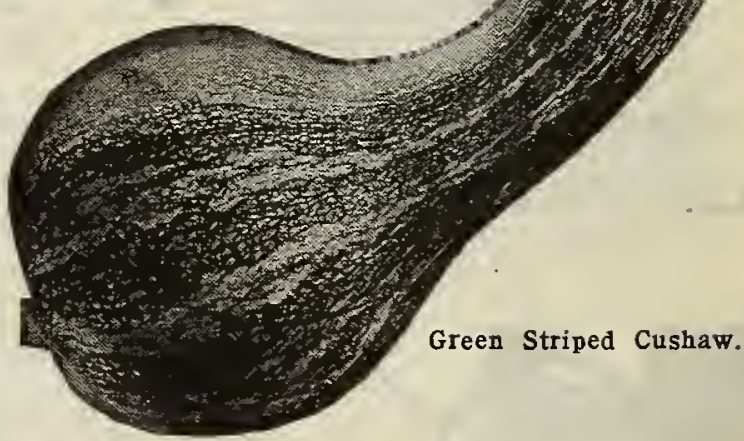

Green-striped Cushaw. Fruits very large, with crooked neck; color creamy white, irregularly striped or traced with green; flesh light yellow, very thick, sweet. Very productive and popular in the southern states. Pkt. 10 cts., oz. 15 cts., $1 / 4$ lb. 40 cts., lb. $\$ 1.25$, postpaid.

King of Mammoth. Extremely large, orange colored, often weighing 50 pounds. Round. Pkt. 10 cts., oz. 15 cts., $1 / 4$ lb. 40 cts., lb. $\$ 1.50$, postpaid.

Yellow Cushaw Crookneck. Grows to a medium size; color light yellow, and is the best variety for table use. Should have a place in every home garden and is also an excellent market sort. Pkt. $10 \mathrm{cts.,} \mathrm{oz.} 15 \mathrm{cts} ., 1 / 4$ lh. 50 cts.. lb. $\$ 1.25$, postpaid.

Chirimen. A Japanese variety of excellent quality. Pkt. 10 cts., oz. 25 cts.

BLOSSOM CIRCLE OF THE YEAR IN
SOUTHERN GARDENS
By Julia Lester Dillon
$\begin{aligned} & \text { First and only book dealing exclusively with } \\ & \text { methods, materials and problems of southern } \\ & \text { ornamental gardening. 200 pages; cloth; profusely } \\ & \text { illustrated; } \$ 2.65 .\end{aligned}$




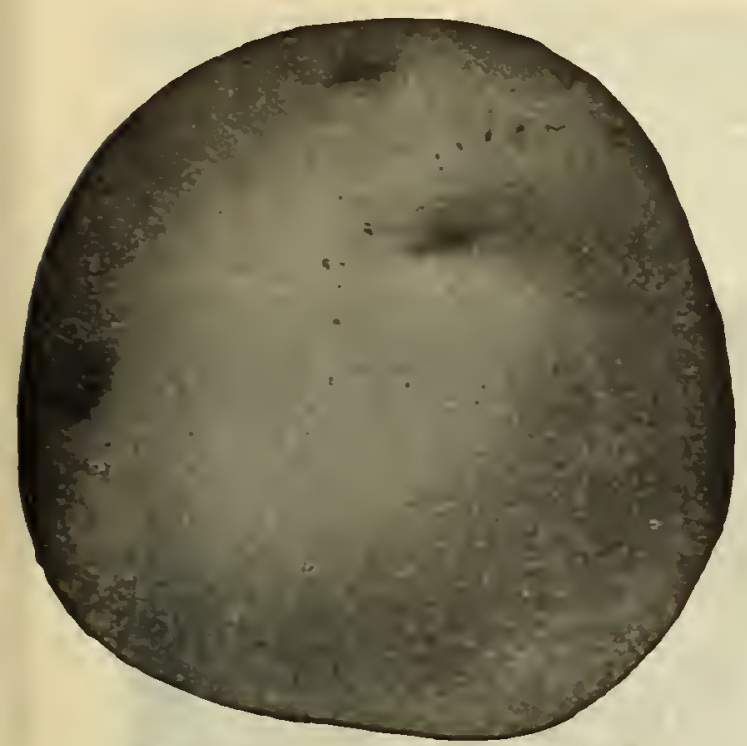

Bliss Red Triumph, Extremely Hardy.

\section{SELECTED SEED POTATOES \\ NORTHERN-GROWN STOCK, SELECTED AND GROWN ESPECIALLY FOR SEED}

Prices fluctuate, Write us when you are ready to purchase, stating quantity wanted. Potatoes are forwarded by express or freight as directed, purchaser paying charges. We assume no risk on Potatoes, and ship strictly on purchasers responsibility. Sacks contain $2 \frac{1}{2}$ bushels.

One peck uill planl aboul 100 feel of rou. or 100 hills: 10 bushels are required for an acre.

Good, well-drained, Abrous $10 a \mathrm{~m}$ will produce Potatoes under right climatic conditions. For early Potatoes, which mature eight to ten weeks from planting, the soll must be rich. Potatoes are planted at various times-both early and late. Cut the tubers so there will be two to three eyes to each piece. Plant in hils or rows 3 feet apart and from. 15 to 18 inches apart in the row. Spray the leaves of the young plants with a bordeaux-arsenate mixture as a protection against blight and attacks of beetles.

Irish Cobbler. Extremely carly-a world-wide favoritc. It is a most cxcellent extra-carly variety producing plump liandsome tubers of good size and excellent quality". The vines make short upright growth. so that the hills may be only a short distance apart. The flesh is pure white, with a clean, smooth white skin with strong wcll-developed cyes slightly indented. In quality they are crcellent, always cooking dry and mealy. Splendid keepers, and a first-class sort worth the attention of all Potato growers. Natures in 80 days. Pk. $\$ 1.25$, bu. $\$ 4.00$ sack $\$ 9.75$.

True Early Rose. The Early Rose is the old standard carly Potato; rosy blush skin; white flesh; productive and of excellent flavor; a fine kceper. A standard variety that has been popular for years. Pk. \$1.25, bu. \$4.00, sack \$9.75.

Bliss Early Red Triumph. It is an extra early variety. The tubers are of medium size, round and uniform in shape, eyes slightly depressed; color a beautiful red. Its great beauty, productiveness, and fine quality make it one of the best extra-carly market varietics. especially for the South. Pk. $\$ 1.00$ bu. $\$ 4.00$. sack $\$ 9.75$.

Spaldings' No. 4 Rose. A popular and large-yiclding carly variety, coming in a little later than the regular Early Rose, but ordinarily gives larger yields and better crop results. Large sized round potato, pinkish skin; good kecping and shipping qualitics; for either carly or late crop. We have no hesitation in recommending it as a most satisfactory and profitable varicty. Pk. \$1.25, bu. $\$ 4.00$, sack $\$ 9.75$.

Green Mountain. A large, handsome, pure white Potato for main or late crop; prolific yiclder and invariably of fine table quality, conking dry and mealy. It has largely supersederl other varieties for late plantings, is also one of the best varieties fot main crop, maturing about two weeks later than the lrish Cobbler. Pk. \$1.25. bu. $\$ 4.00$, sack $\$ 9.75$

We carry all line of Sprayers, Bordeaux Mixture, Arsenate of Lead,

Blue Stone, Blue Stone,
Paris Green.

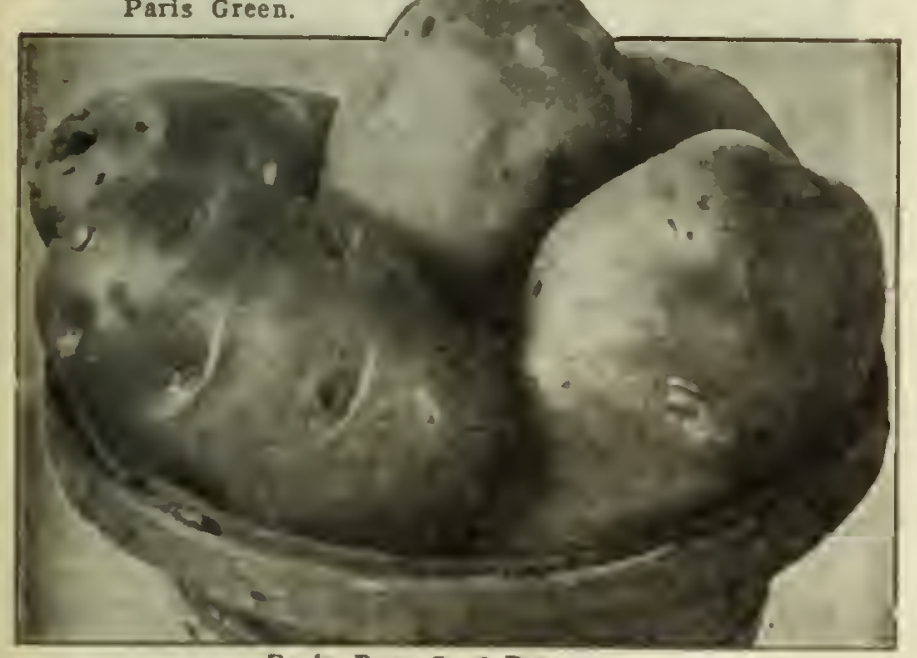

Early Rose Seed Potatoes.

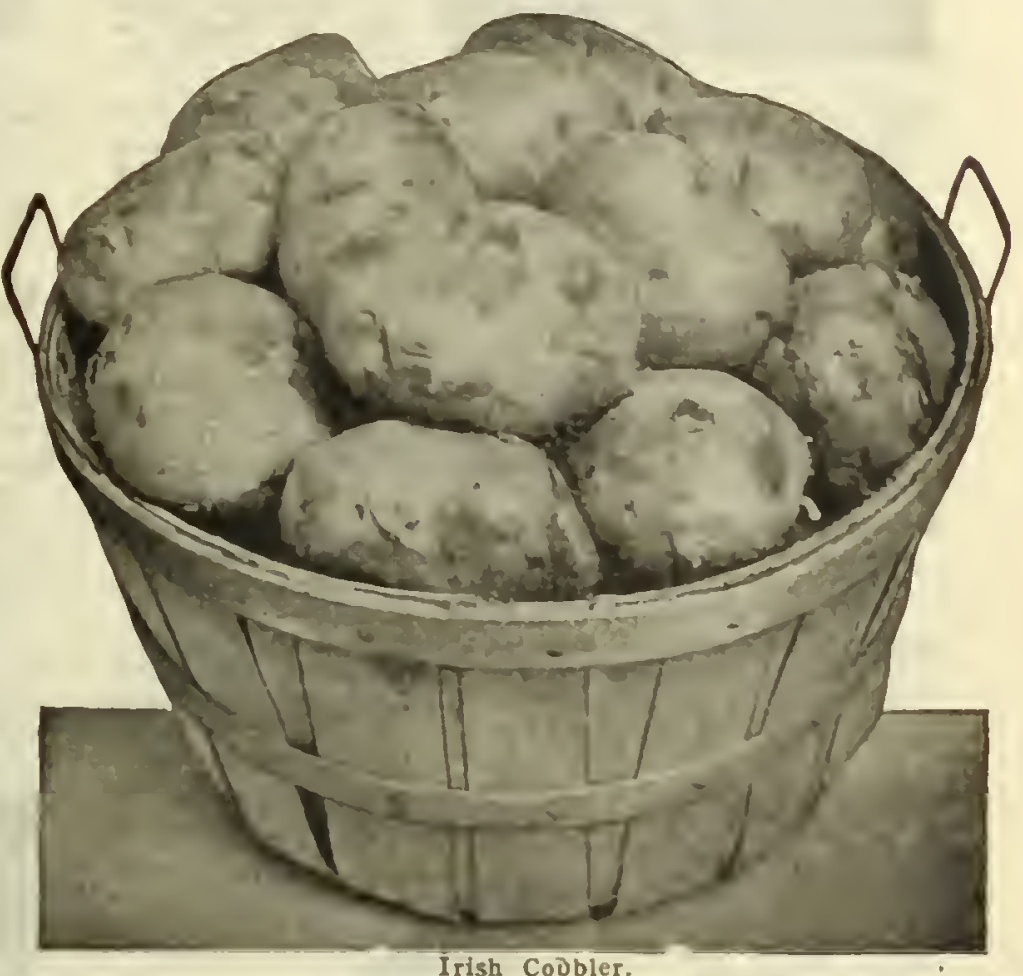

Improved Peachblow. An old favorite for late plant ing; skin slightly tinged with pink; of attractive appearance, and one of the best kecpers. Our stock of these l'otatoes is superiot to the old l'sactiblow, being rounder in sliape and of hetter quality. Stands drought and heat beuer than nther lote cropping: varietics. J'k. \$1.25. bu. \$4.00, sack \$9.75

\section{Certified Seed Potatoes}

We lave been fortunate in sceuring several hundred sacks of Fixira Fancy (ertilied fïld lnspected lrist Cobblers. Government records show that ecreified sect increases the yield $50 \%$

l'rice, pk. \$1.\$0, bu. \$\$.m. sack \$12.25.

HOME VEGETABLE GARDENING FROM A TO $z$

A valuable lonok by Adolpli Kruhm. The discussion of each verctable is practical aurl romplcte from sowing sceds to what kinds to grow in different soils anel sections. About 3m pages, more than $3(x)$ photographic
reproductions. and 32 four-color illustralions, Bound in clotli, \$2.00 postpaid.

Cold Storage Potatoes we will bave n nice stock of Seed Potaloes kept in cold storage for late 


\section{RADISH}

One ounce will sow 50 feet of drill; 8 to 10 pounds, 1 acre. Ready for market in 25 to 45 days.

To be tender and crisp, Radishes must be grown quickly. and $t h$ is requires rich soll and plenty of moisture. Com. mencing $\nabla i t h$ the first mild spell in the spring, sov at intervals of ten days, intervals of light, rich, in a light, rich, May also be sown as a catch crop between rows of beets, let. tuce, onjons, etc., or sown in the enme dri11 with slow-growing regetables like carrots and parsnlps. When forced in hotbeds, they must have plenty of ventilation and moisture. For fall and winter use. fall and winter use, sow the winter varieSeptember until October 10 th.

Icicle. A fine white radish about 5 inches in length and quite slender. This is one of the very best of the summer radishes. Skin is smooth and thin; flesh fine grained, white and crisp. A good variety for family use. Pkt. $10 \mathrm{cts.,}$ oz. $15 \mathrm{cts.}, 1 / 4$ lb. 30 cts., lb. $\$ 1.00$, postpaid.

Early Scarlet Globe (see inside front cover). An ex cellent variety of fine quality and appearance; brillian colored skin; very round in shape. Pkt. $10 \mathrm{cts.}, 0 z .15$ cts., $1 / 4$ lb. 40 cts., lb. $\$ 1.00 ; 5$ lbs. $\$ 4.00$.

White Box. The Philadelphia gardeners are partial to this Radish, and it is grown to some extent for shipment to that market. It is a rapid grower, rather small in size, with brittle, sweet flesh and pure white skin. Pkt. $10 \mathrm{cts}$., oz. $15 \mathrm{cts}$., $1 / 4 \mathrm{lb}$ l $30 \mathrm{cts}$., lb. $\$ 1.00$ postpaid.

French Breakfast. A white-tipped, olive shaped rort, and one of the earliest forcing varieties, but should be used while young. Pkt. $10 \mathrm{cts}$., oz. $15 \mathrm{cts} .1 / 4 \mathrm{lb} .35 \mathrm{cts}$. Ib. $\$ 1.00$ postpaid. 5 lbs. $\$ 4.00$.

Early White-tipped Scarlet Turnip. (Rosy Gem). A fine forcing Radish. Very early; makes beautiful, deep scarlet roots, with white tip; crisp, tender and mild. Pkt. $10 \mathrm{cts}$., oz. 15 cts., $1 / 4$ lb. 30 cts., lb. $\$ 1.00$, postpaid. 5 lbs. $\$ 4.00$.

Long Scarlet Short-Top. Long, bright scarlet, fine for forcing. Pkt. 10 cts., oz. 15 cts., $1 / 4$ lb. 35 cts., lb. $\$ 1.00$, post paid.

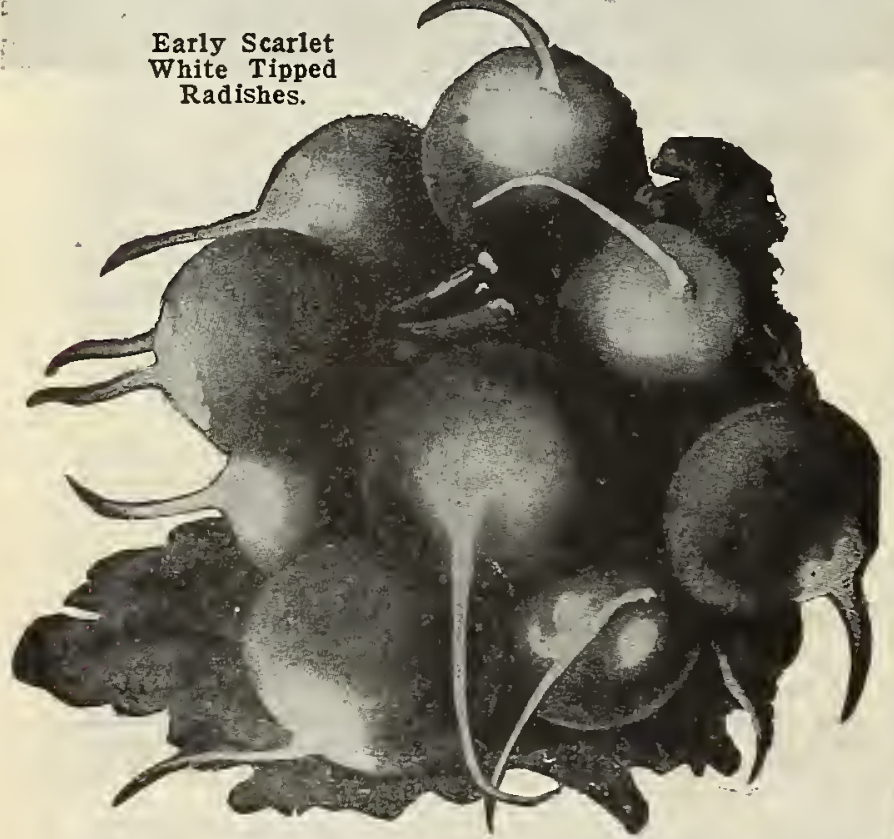

White Strasburg. Large, long, solid; one of the best for summer use. Pkt. $10 \mathrm{cts}$., oz. $15 \mathrm{cts} ., 1 / 4 \mathrm{lb} .30 \mathrm{cts}$., lb. $\$ 1.00$, post paid.

Crimson Giant. For forcing or outdoor planting. Although twice the size of other forcing sorts this does not get pithy or hollow; the skin is crimson, flesh is white, tender. crisp and sweet-flavored. Sow seed thinly to permit root growth. Pkt. $10 \mathrm{cts}$., oz. $15 \mathrm{cts}$., $1 / 4$ lb. 40 cts., lb. $\$ 1.15,10$ lbs. $\$ 8.00$.

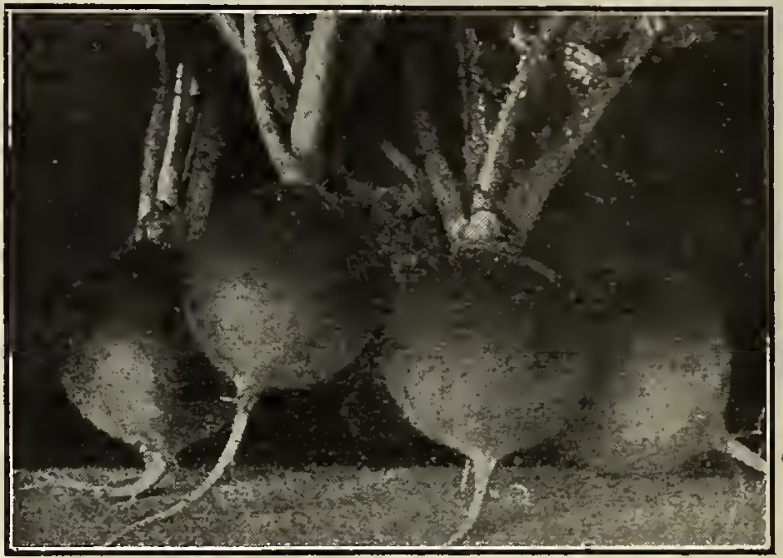

Early Red or Scarlet Turnip Radish.

Early Red, or Scarlet Turnip. A quick-growing, round red Radish, with small tops; rich red color; crisp and tender. Fine for early outdoor planting. Pkt. 10 cts., oz. $15 \mathrm{cts} ., 1 / 4$ lb. $40 \mathrm{cts}$., lb. $\$ 1.00$, postpaid. Buyers expense, 90 cts. $\mathrm{lb}$.

\section{For Winter-Winter Radishes}

Sow during August, September until October 10th, and when freezing weather comes on, pack in sandy soil, either buried outdoors or in a damp cool cellar, where they will keep all winter.

Rose China Winter. Roots cylindrical; color bright rose. flesh white and of superior quality. One of the best. Pkt. 10 cts., oz. 15 cts., $1 / 4$ lb. 25 cts., lb. 85 cts., ppd.

Long Black Spanish. One of the hardiest of Radishes; oblong in shape; of large size. Pkt. $10 \mathrm{cts}$., oz. $15 \mathrm{cts}$. . $1 / 4$ lb. 25 cts., lb. 85 cts., postpaid.

White Chinese, or New Celestial. Large stump-rooted white skin and flesh, mild in flavor, brittle and never woody. For late planting and a splendid keeper. Pkt. 10 cts., oz. 15 cts., $1 / 4$ lb. 30 cts., lb. 90 cts.

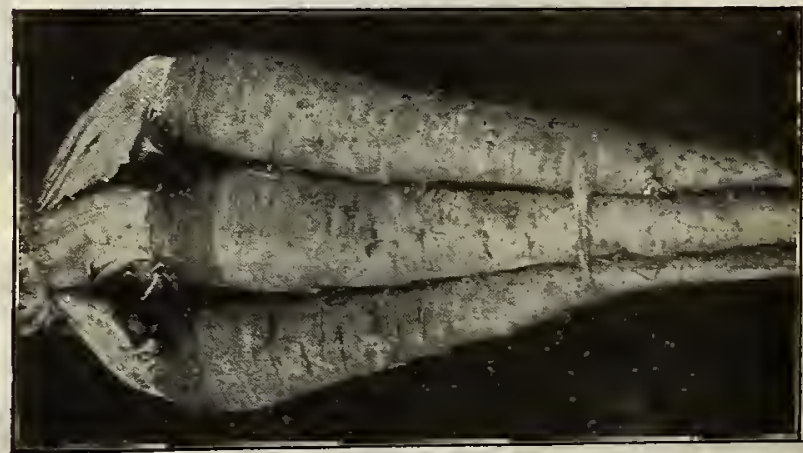

Salsify.

\section{Salsify, or Vegetable Oyster \\ One ounce will sow about 50 feet of drill.}

Soll and culture should be the same as for parsnips. Make sowings as early as practicable in spring. Salsify is boiled like parsnips or carrots, or is half-bolled and grated, then made into balls, which are dipped into batter and fried like Carrots.

Mammoth Sandwich Island. A new and improved type, producing roots of nearly double the size and weight of the old sort, and in every way preferable. Much valued by market-gardeners, as it grows stronger and is less inclined to branch. Pkt. 10 cts., oz. 20 cts., $1 / 4$ lb. 65 cts., lb. $\$ 2.35$, postpaid. Buyers expense, $\$ 2.25$ per lb. 


\section{SQUASH, or CYMBLING}

An ounce of the summer varieties will plant 30 hills; of the winter sorts: 15 hills.

There are two types of these, the summer and winter varieties. The former are used when they are about half. varieties. The form ar tender, but are of no value when grown and are soft and tender, is one of our finest winter matured. The winter squash is one or our fnest wiste can regetahles, and should he largely grown. No variety can plants are very susceptihle to cold, damp weather. For the summer varieties hills can he made 4 to 6 feet apart. For the winter varieties they should he 8 to 10 leet apart. Sow the to ten seeds in a bill, and after danger trom to The striped heetle and large squasb hug are very trouhlesome, hut can he held in check if tohacco dust or stems are freely used in the hills and the plants dusted frequently ahout with Slug-Shot, air slacked lime, or ine ashes mixed with road dust. Matures in 65 to 125 days.

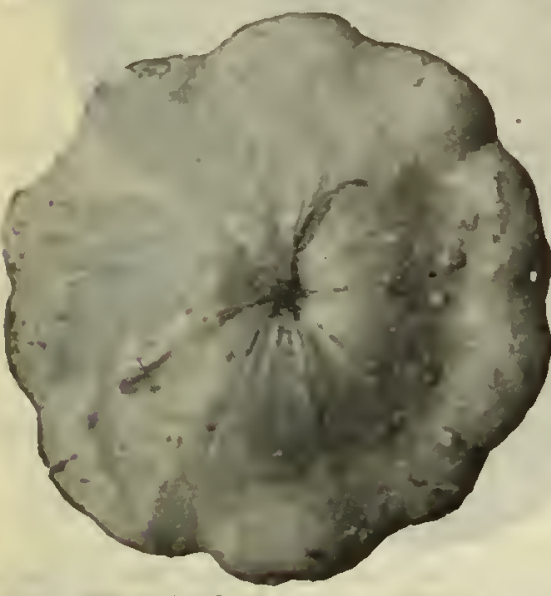

Wyatt's Early White Bush.
Wyatt's Early White Bush. or Patty Pan. Very' largely grown in the South. Early. productive and a good shipper. I'kt. $10 \mathrm{cts}$. oz. 15 cts., $1 / 4$ lb. 35 cts., Ib. $\$ 1.00$ postpaid.

ibs. for $\$ 4.50$

Earllest Prolif ic. An ex tremely early variety" of sum iner Squash o Pat ty-Pan type: a Lush Squash of remarkably productive and of good quality. Pkt. $10 \mathrm{cts}$. Oz. $15 \mathrm{cts.o} 1 / 51 \mathrm{~b} .35 \mathrm{cts} .01 \mathrm{~b} . \$ 1.25$. postpaid, 5 lbs. $\$ 5.00$

Mammoth White Bush. Is an improved selection of the ald "Early White Bush." the highly favored early summer squash. The newer sort is mucl, largers and deeper, has fewer scallops. which anves waste. and is a heavier producer. Pkt. $10 \mathrm{cts.}$. oz. $15 \mathrm{cts} ., 1 / \mathrm{lb} .35$ cts. Ib. $\$ 1.25$. 5 lbs. for $\$ 5.00$.

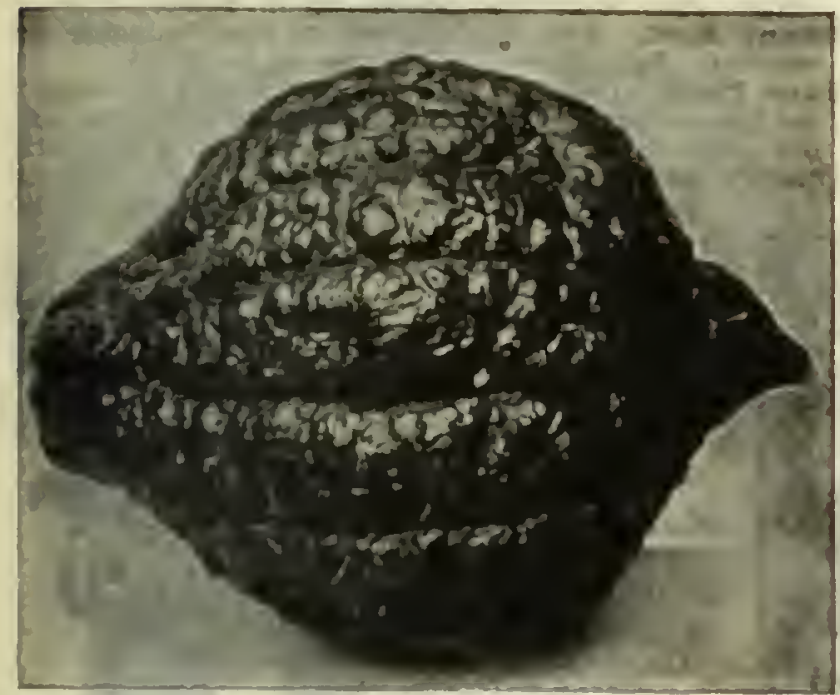

Huhhard Squash.

Hubbard. large size, fleqlı bright orange, fine grainerl dry and goorl flavo:. Pkt. 10) cts., oz, 15 cts.. 1/4 lis 35 cts.. (1). \$1.0().

Boston Marrow. V'ery popular for fall and winter; thin rind, orange color, yellow flesh, fine for pies, cood keeper. I'ke, $10 \mathrm{cts.0}$ oz. $15 \mathrm{ct} 8$. If lb. 3.5 cts., Ib. \$1.0n. Golden Custard Bush. Similar to the White Buslı. but vellow. Plt. $10 \mathrm{cts}, 0 \mathrm{z}, 15 \mathrm{cts}, 1 / 311), 35 \mathrm{cts}$. It) $\$ 1.25$.

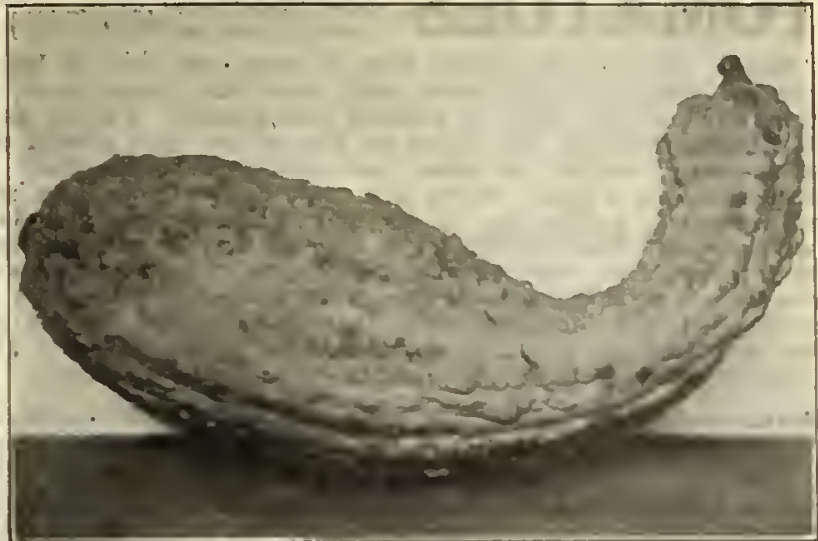

Giant Golden Summer Crookneck.

Giant Golden Summer Crookneck Squash. Mucl larger than the original Sunmer Crookneck and mor desirable, being as early. and of more vigorous growth. The Hesh is thick, yellow. Pkt. $10 \mathrm{cts.}$ 0\%. $20 \mathrm{cts}$. $1 / 4$ lb. 45 cts.. Ib. $\$ 1.25$

English Marrow. Fruits shorter than Long Cream. Pkt. $10 \mathrm{ctg} .0 \mathrm{0z}, 25 \mathrm{cts} .1 / \mathrm{lb} .75 \mathrm{cts}$.

Long Cream. Bears creamy white oblong fruits. Pkt $10 \mathrm{cts.o} \mathrm{0z.} 25 \mathrm{cts.0} / \mathrm{lb} .75 \mathrm{cts}$.

Bush Fordhook Squash. Inequalled in quality and delicious sweetness by any variety. whether for summer or winter use. If stored before frost in a warm dry place, it will furnish winter squash for table use unti the new crop is ready. Pkt. $10 \mathrm{cts.,} \mathrm{oz.} 20 \mathrm{cts.}$.'s $1 \mathrm{~b}$ $40 \mathrm{cts} ., \mathrm{lb} . \$ 1.25$.

\section{SPINACH}

One ounce will sow 100 feel of drill; 20 folsuds fer acre in drills, or 25 to 30 pounds broadcast. One-half pound is sufficient for an averoge gorden.

Should bo grown in every gardeu for greeus. It is very healthiul, and should he treely used, as it is not difficult to ralse, requires little cultivation, and seed is easily grown. It can be sown in drills, which should he ahout 18 inches apart. covering the seed with an inch of soll or it can he sown hroadcast. Can he sown in Fehruary. March, and April, or in Septemher or Octoher for late rall and early spriug use. Ready to cut in 40 to 60 days.

Norfolk Saroy, or Bloomsdale. A hardy varicty; very early, producing leaves resembling a Savoy cabbage a good variety for fall secding. P'kt. $5 \mathrm{cts.} 0 z .10 \mathrm{cts}$ $1 / 3$ lb. 25 cts.. lb. $50 \mathrm{cts.} 5$ lbs. $\$ 2.25$, postpaid. 100 lbs. $\$ 25.00$. 500 lbs. $\$ 100.00$

Lone Season. Well-known variety for either fall of spring seeding. Stands a lons time in edible condition Pkt. 5 cts.. 0z. $10 \mathrm{cts..} 1 / 4 \mathrm{lb} .25 \mathrm{cts} . . \mathrm{lb} .50 \mathrm{cts.}$ postpaid. New Zealand. Produces teniler Spinach even during hot weather, and will grow in noor soil. Pkt. $10 \mathrm{ct}$. oz. $15 \mathrm{cts}$. . I lb. $35 \mathrm{cts} .11$, $\$ 1.00$. postpaid.

KIne of Denmark Spinach. This new variety is slow to go to seed. It inakes a very quick growtli of dlark green leaves, large and attractively crumpled. Plant Bome without lall. Pkt. $10 \mathrm{cts}, 07.15 \mathrm{cts}$. 1/ Ib 25 cts., lb. $60 \mathrm{cts} ., 10$ lbs. $\$ 4.75$.

\section{Norfolk Savor.}

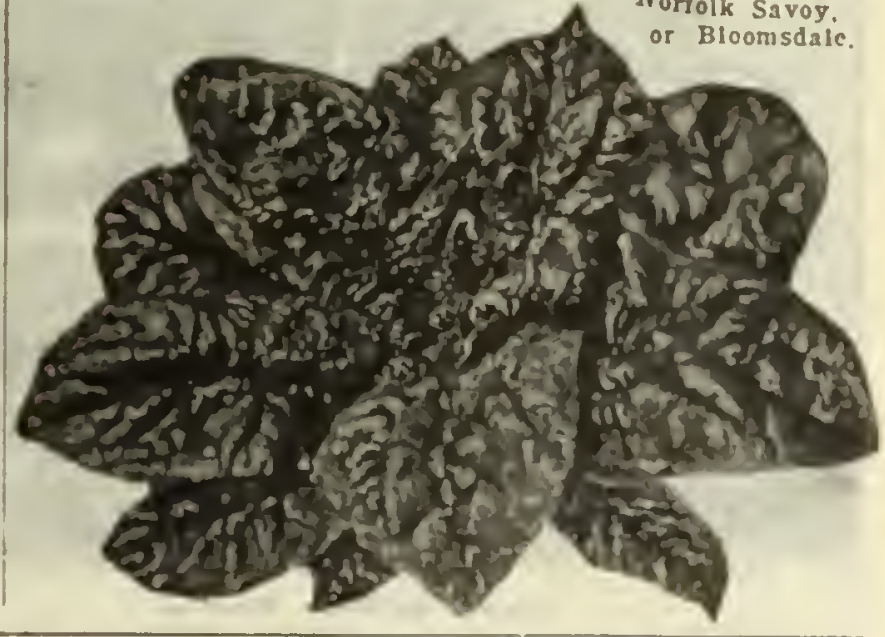


One ounce will make about 1,500 plants, 4 ounces will make plants enough for an acre.

Six or eight weeks before frost is over sow seed in hotbeds or in pots or shallow boxes in the house, and when the plants have made four leaves, transplant in the beds to promote root-growth. Expose as much as possible to harden them, so that when set out on the open ground they will be strong and stocky, but do not allow the growth to be checked. Transplant 3 to 4 feet apart in a light, warm soil, and cultivate as long as possible. When transplanted, puddle the plants and shade them a.few days until they are well rooted. The earliest fruits may be had by growing in pots and shifting to large pots as they become filled with roots. Earliness may also be promoted by pinching off all the branches except the one most thrifty and tying this and the main stem to stakes. If all useless growth is removed by pinching out the side branches, the plants may be set closer and will produce more perfect fruits and a more abundant crop.

Brimmer (see front cover). A new Tomato, well adapted to Southern conditions, larger than most kinds. The fruit is unusually large, flat curved, of a bright red color, thick, meaty and contains but few seed. Pkt. 10 cts., $1 / 2$ oz. 50 cts., 1 oz. 75 cts., $1 / 4$ lb. $\$ 2.25$, 1b. $\$ 8.00$. Wyatt's Matchless (see inside front cover). Large. bright red, long keeping tomato. The solid fruit is produced on strong, vigorous, prolific vines. Very distinct. Pkt. $10 \mathrm{cts} ., 1 / 2$ oz. 20 cts., oz. 35 cts., $1 / 4 \mathrm{lb}$. $\$ 1.00,1 b . \$ 3.50$.

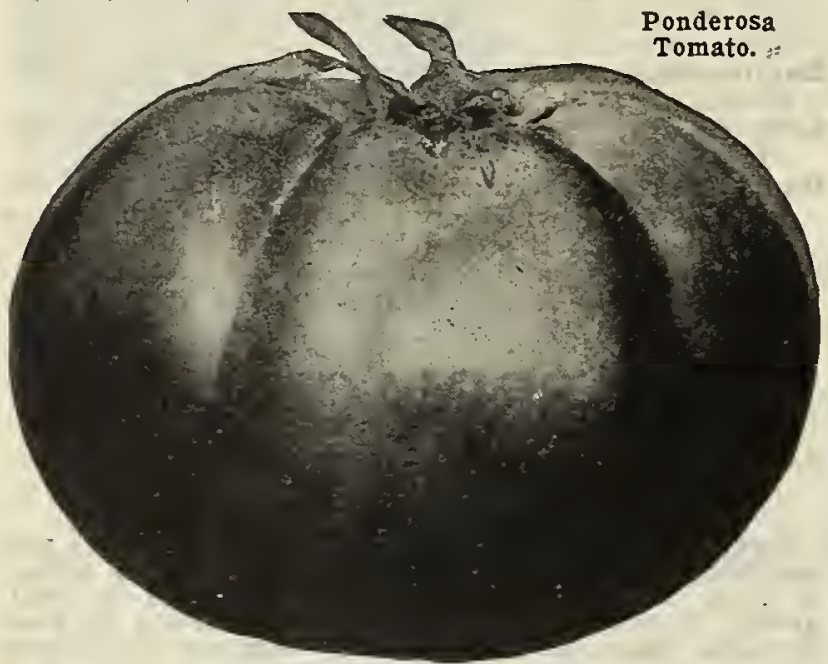

Ponderosa. Fruits very large, solid and bright crimson. Pkt. 10 cts., oz. 50 cts., $1 / 4$ lb. $\$ 1.40$, lb. $\$ 5.00$.

Crimson Cushion. An extremely large, bright red variety of the Ponderosa type; ripens evenly; good quality; late. Pkt. 10 cts., $1 / 2$ oz. 35 cts., oz. 60 cts., $1 / 4$ lb. $\$ 1.90,1 \mathrm{~b} . \$ 6.50$, postpaid.

Greater Baltimore. A main-crop variety, excellent for canning; fruit large, smooth and well formed; color bright red; a heavy cropper. Pkt. 10 cts., oz. 30 cts. $1 / 4$ lb. 90 cts., 1 b. $\$ 3.25$, ppd.

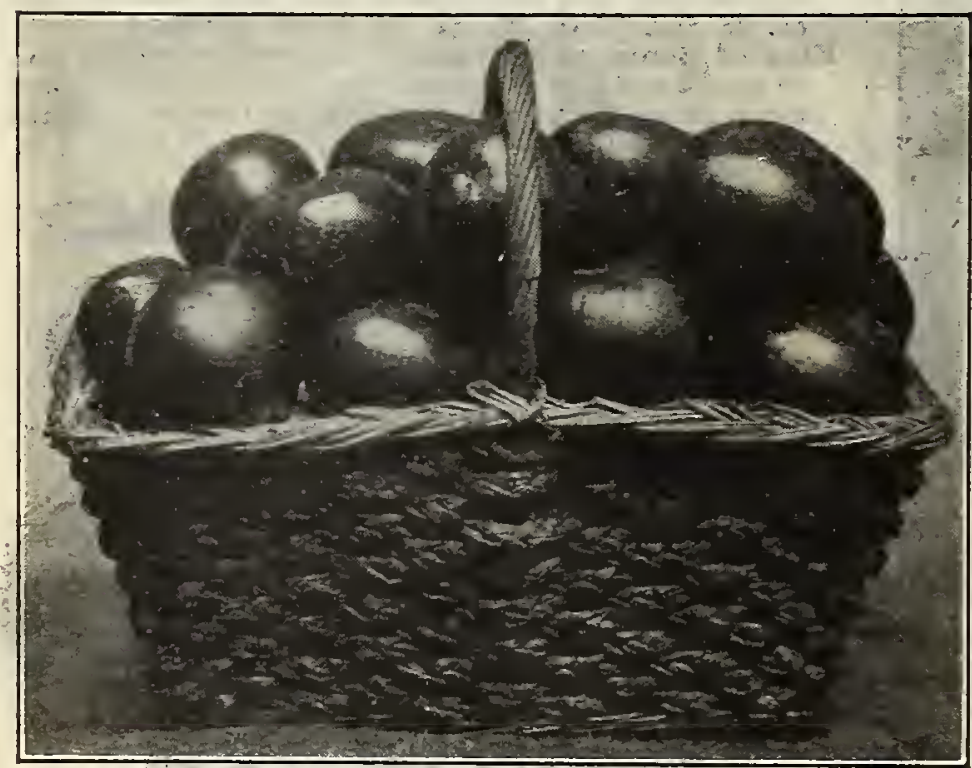

Greater Baltimore Tomatoes.

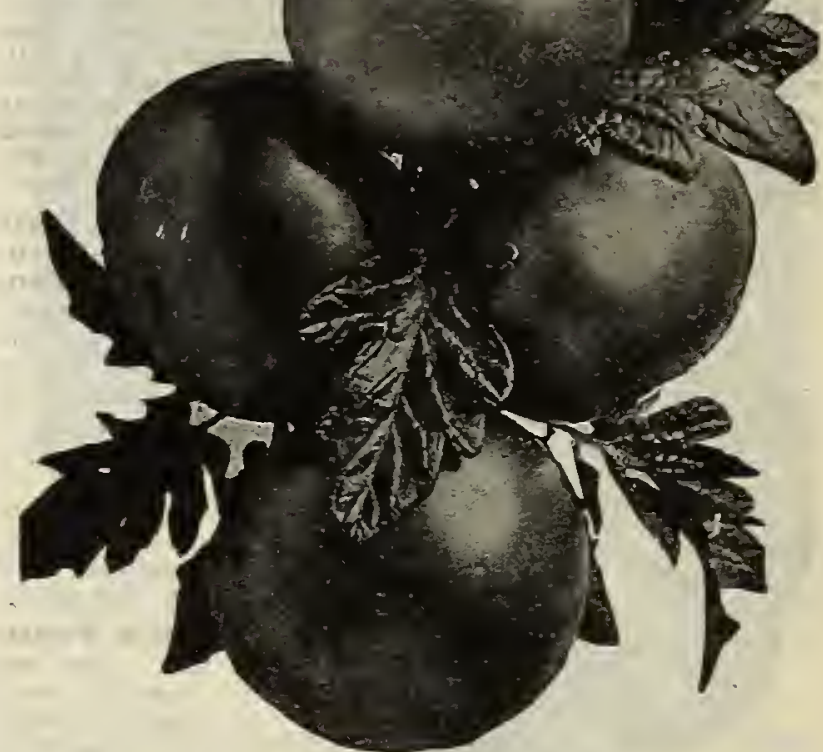

John Baer. Very early and an exceedingly heavy cropper; produces fruit of medium size and fine flavor. Pkt. $10 \mathrm{cts}$. oz. $25 \mathrm{cts} ., 1 / 4$ lb. 80 cts., 1 lb. $\$ 3.00$.

Livingston Beauty (Purple). Vines large, vigorous and heavy bearers, fruit large, uniform, very smooth purplish pink skin; flesh light pink. Pkt. $10 \mathrm{cts.,} \mathrm{oz.} 35$ cts., $1 / 4$ lb. 85 cts., lb. $\$ 2.85$.

Dwarf Champion." Fruit of medium size; very prolific. Pkt. 10 cts., oz. 50 cts., $1 / 4$ lb. $\$ 1.25$.

Earliana. Extra early; bright red, smooth. Pkt. 10 cts., oz. 45 cts., $1 / 4$ lb. $\$ 1.00,1$ lb. $\$ 3.00$.

Acme. One of the earliest; handsome, medium-sized fruit. - Pkt. 10 cts., oz. 35 cts., $1 / 4$ lb. $\$ 1.00$.

Bonny Best. Very early; medium size; valuable for market. Pkt. $10 \mathrm{cts}$., oz. $50 \mathrm{cts}$., 1/4 lb. $\$ 1.25$.

June Pink. This is really a pink "Spark's Earliana," as it resembles that variety in every way except the color, which is pink. Pkt. 10 cts., oz. 45 cts., $1 / 4$ b. $\$ 1.25$. Chalk's Early Jewel. Very fine; large, solid, smooth and bright red. Pkt. 10 cts., oz. 45 cts., $1 / 4 \mathrm{lb}$. $\$ 1.00$.

Wyatt's Beefsteak. Is very large, round and regular; bright scarlet skin, solid flesh of best quality, seed cells small. Plants are very prolific, fine appearance. Pkt. 10 cts.. $1 / 2$ oz: 30 cts., oz. 55 cts., $1 / 4 \mathrm{lb}$ $\$ 1.60$.

Magnus. Potato leaved: strong growing vines, a heavy cropper. Fruit globe - shape and ripens evenly. $\mathrm{Pkt}$. $10 \mathrm{cts}$., $1 / 2$ oz 20 cts.. oz. 55 cts., $1 / 4 \quad 1 \mathrm{~b}$. $\$ 1.75$.

Y e 11 o Pear-shaped. Small, for preserves, much resembling a pear in form. Pkt. 10 cts., oz. 45 cts., $1 / 4$ lb. $\$ 1.50$, postpaid.

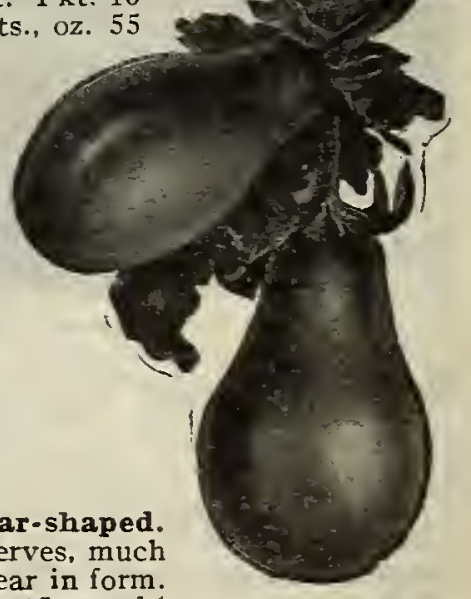

Yellow Pear. Shaped Tomatoes

Southern-Grown Watermelon Seed produces the best melons in the world. Our seed is the best Southern-Grown. 


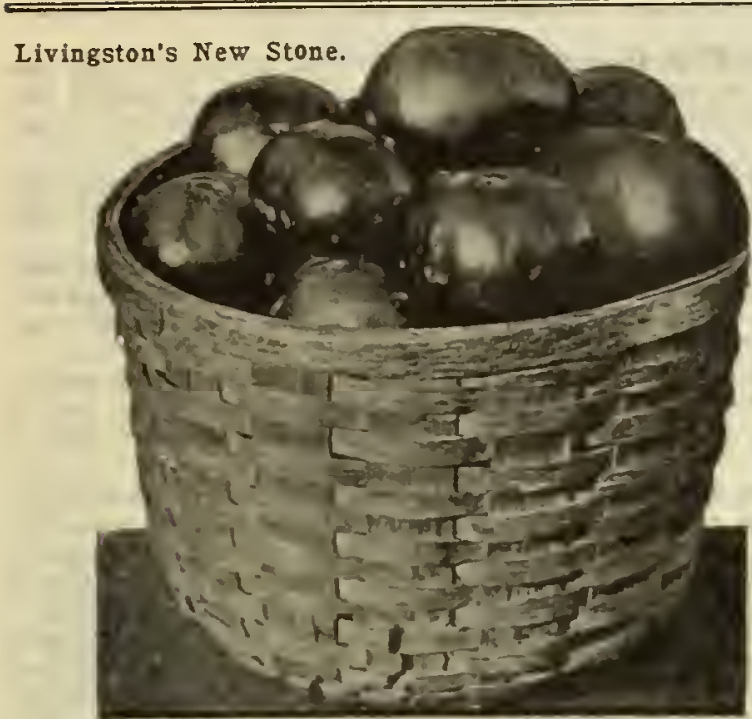

Livingston's New Stone. A standard and general favorite with truckers and canners; always dependable; very vigorous and productive. Fruits round, large, solid. smooth and deep red in color. Pkt. 10 cts., oz. $30 \mathrm{cts.} 1 / 4$ lh. $75 \mathrm{cts} .1 \mathrm{~b} . \$ 2.50$, prepaid.

Red Rock. A main-crop variety similar in character to the Stone; very productive, a good shipper. Fruit is a brilliant red; exceptionally smooth and uniform in size; flesh is very firm; an excellent variety for canning. Pkt. $10 \mathrm{cts} .0 \mathrm{0z} .30 \mathrm{cts.0} 1 / 4$ lb. $90 \mathrm{cts} ., 1 \mathrm{lb} . \$ 3.25$. postpaid.

New Globe Tomato. This new Globe or Ball-shaped tomato is ideal for the home garden; it is excellent for slicing. The rich, juicy, tomato flavor gives a certain zest and joy in the cating. The skin is a smooth. glossy red; the flesh is firm and it has few seeds. Pkt. $10 \mathrm{cts}$. $1 / 2$ oz. $25 \mathrm{cts} .$, oz. $40 \mathrm{cts} .{ }^{1 / 4} \mathrm{lb}$. $\$ 1.25$, lb. $\$ 4.00$.

Golden Queen. Brick yellow. Pkt. 10 cts., 1/2 oz. $25 \mathrm{cts} ., 0 z .40 \mathrm{cts.}, 1 / 4$ Ib. $\$ 1.20$, Ib. $\$ 4.00$.

Golden Ponderosa. A Yellow Gem. This is a yellow Ponderosa equal in size to that magnificent variety. Sliced and served with the Purple Ponderosa, it makes a highly decorative and appetizing salad. Runs nearly true to type with a small percentage of mixed fruits. Pkt. 10 cts., 1/2 0z. 35 cts., oz. $60 \mathrm{cts} .1 / 4$ lb. $\$ 1.75,1 \mathrm{~b} . \$ 6.00$

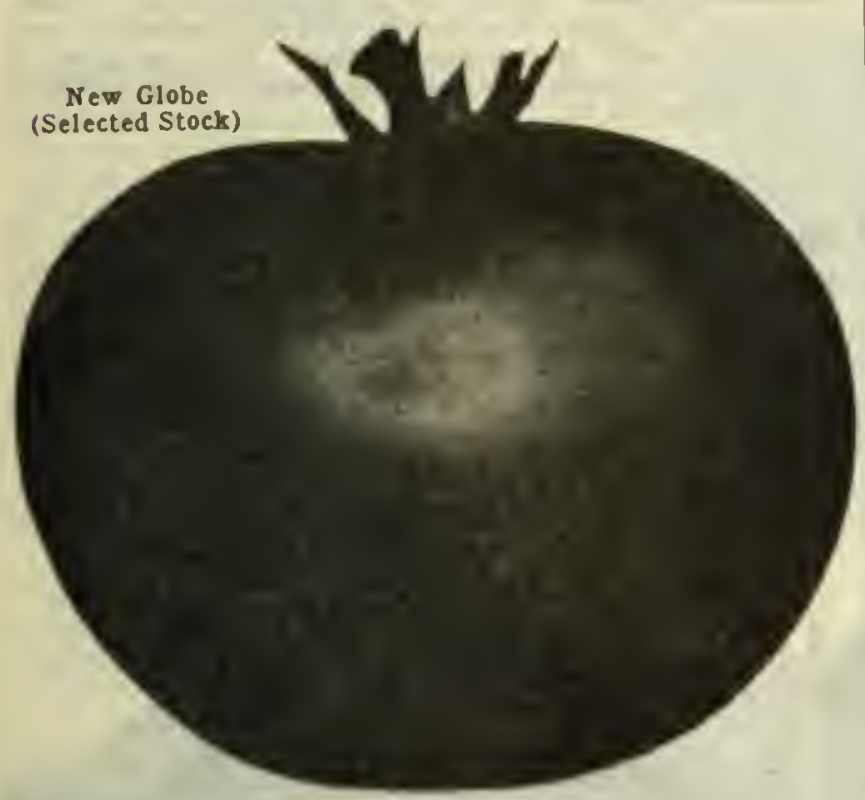

\section{Wilt Resistant Tomatoes}

Marrel. A good bearer, heavy foliage, medium sized. Pkt. $10 \mathrm{cts} ., 1 / 20$ oz. $35 \mathrm{cts}, 0 z .60 \mathrm{cts}, 1 / 1 / \mathrm{lb}$. $\$ 2.00$.

Norduke. An cxcellent home garden and local market sort. Pkt. $10 \mathrm{cts} .1 / 2 \mathrm{oz} .35 \mathrm{cts} ., 0 z .60 \mathrm{cts} ., 1 / 4 \mathrm{lb} . \$ 2.00$.

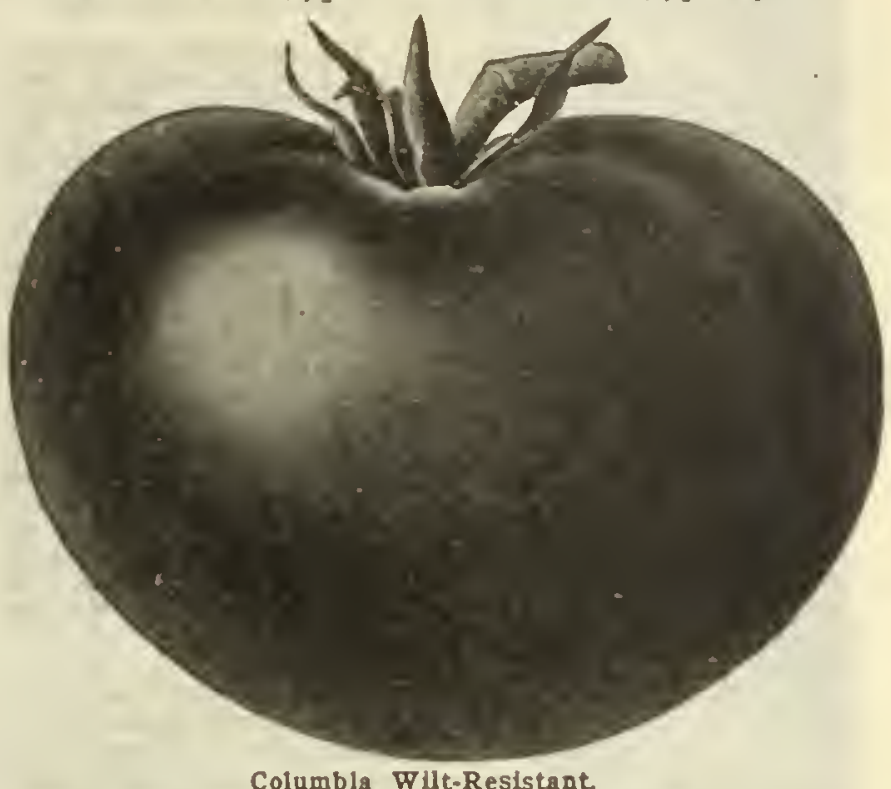

(Plant some, you will be pleased with results.)

Norton. Resembles Livingston's Stone, good kecper and yiclder. I'kt. $10 \mathrm{cts.,}$ t. $02.35 \mathrm{cts} ., 0 z .60 \mathrm{cts}$. if lb. $\$ 2.00$

Columbia. Our seed of this variety is the very best California grown. l'kt. $10 \mathrm{cts}, 0 z .60 \mathrm{cts}$.

Louislana Pink. Pink 111eated. Pkt. $10 \mathrm{cts.0} \mathrm{Iś} \mathrm{oz.} 60$ cts., oz. $\$ 1.00$.

Louislana Red. The highest yiclding Tomato for the Carolinas. P'kt. $10 \mathrm{cts} ., 1,0 z .60 \mathrm{cts.,} 0 z . \$ 1.00$.

The above six Wilt Resistant varieties have been tried and we know that ther will give you satisfaction. Try some this season.

Tomato Plants. - We can supply all varieties in season. IVrite for prices when ready to purchase.

Tomato Collection.-Six papers of fine Tomato Seed, of the following varietics, mailed to any address in the United States.

\section{for TIVENTY-FIVE CENTS}

One paper Stone One paper Bonny Best One paper Acme One paper Yollow Pear One paper Ponderosa One paper Red Rock

\begin{tabular}{|c|}
\hline 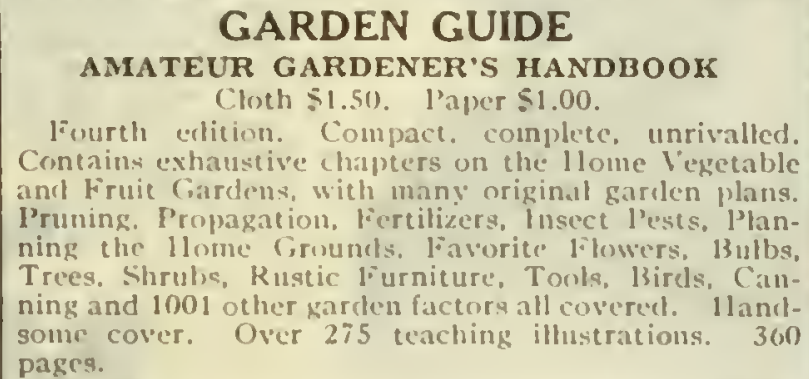 \\
\hline
\end{tabular}

For seasoning

\section{Herbs}

For flavoring soups, ments, etc., a few pot and swect herbs are necessary for every garden.

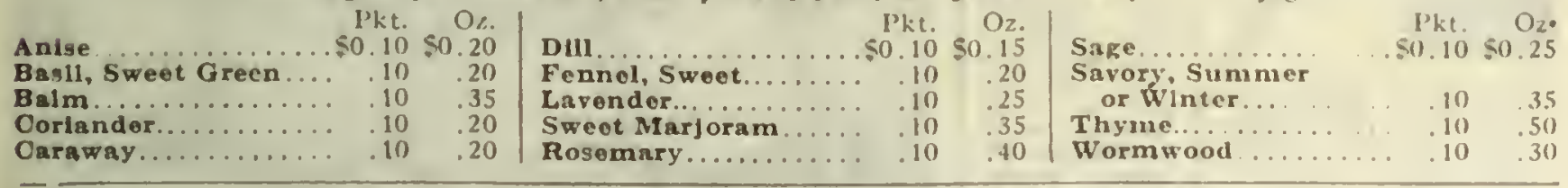

We can supply all kinds of Fertlizer. Let us know what you want. 


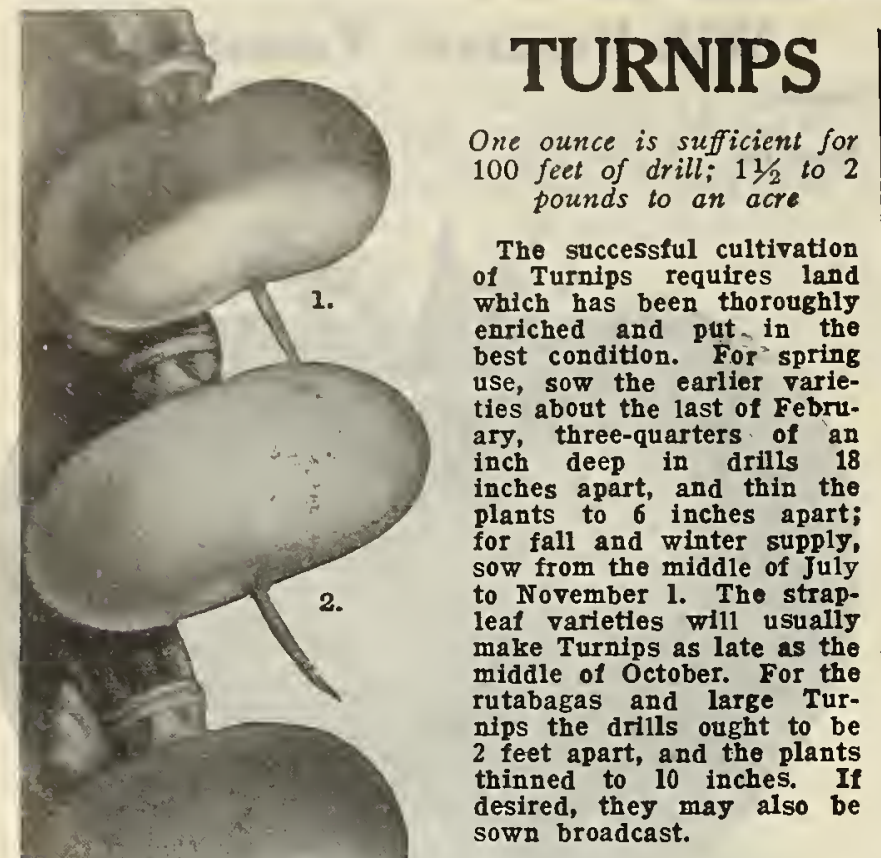

Turnips are easy to grow. Pull them while they are tender and sweet. These Turnips selected for rich flavor, fine grain and handsome appearance. You should sell lots of Turnips and Salad on your local market.

Rutabaga for table and for stock. Nothing bet. ter for feeding cows, hogs and sheep.

\section{Extra Early Purple} Top Milan. An excellent m edi u m size turnip, almost as early as White Milan, smooth white surface, purple top, flat shape, white flesh-its growth is very uniform and quality the best. Pkt. 10 cts., oz. 15 cts. $1 / 4$ lb. 35 cts., lb. $\$ 1.00$.

Early White Milan. Is the earliest tur. nip, but can be used Spring or Fall. The skin is smooth, snowy white, has a polished appearance; medium size, white, tender, sweet. Pkt. $10 \mathrm{cts}$. oz. 15 cts., $1 / 4$ lb. 35 cts., lb. $\$ 1.00$.

White Flat Dutch. It is an early garden variety, popular in the Southern states; is medium sized, sweet, tender and desirable for table use. Pkt. 5 cts., oz. $10 \mathrm{cts.,} 1 / 4 \mathrm{lb}$. 25 cts., 1b. 75 cts., 5 lbs. $\$ 3.00$.

Early Snowball. Small, white, grows quickly, splendid table quality. Pkt. 5 cts., oz. $10 \mathrm{cts.,} 1 / 4$ lb. 25 cts.. lb. 75 cts., 5 lbs. $\$ 3.00,10$ lbs., $\$ 5.00$

Large Amber Globe. Large yellow turnip, used for both table and stock feeding. It resembles the rutabaga and grows to an enormous size. Pkt. 5 cts., oz. 10 cts., $1 / 4$ lb. 25 cts., lb. 75 cts., postpaid.

Red or Purple Top Strap Leaf. This strap-leaf variety is good for early spring and fall use; top red or purple above ground, flesh fine grained; mild flavor. Pkt. 5 cts., oz. $10 \mathrm{cts} ., 1 / 4$ lb. 25 cts., lb. 75 cts.

Mixed Turnips. A mixture of all varieties of garden turnips, early and late sorts, both white and yellow fleshed. Just what people want for the home garden. One sowing will supply turnips for summer and winter use. Pkt. 5 cts., oz. $10 \mathrm{cts.}, 1 / 4$ lb. 25 cts., lb. 60 cts., postpaid.

Purple-Top White Globe. A large, rapid-growing sort with globe-shaped roots. Flesh pure white, and the best flavored; the skin is white, with a purple top. On account of its shape it will outyield any other sort. Pkt. 5 cts., oz. 10 cts., $1 / 4$ lb. 25 cts. 1b. 75 cts., prepaid. Not prepaid, 5 lbs. $\$ 3.50,10$ lbs. $\$ 6.00$.

Cow Horn or Long White. Grows nearly half way out of the ground, carrot shape, usually slightly bent; pure white. Pkt. 5 cts., oz. 10 cts.. 1/4 lb. 30 cts., lb. 90 cts.

White Egg. Quick growing, egg shaped, perfectly smooth pure white variety, grows half way out of ground with small tops and rough leaves, never has rank, strong taste, but the sweet, firm flesh is always mild, rich and fine flavored. Pkt. 5 cts., oz. $10 \mathrm{cts}, 1 / 4 \mathrm{lb} .30 \mathrm{cts}$. lb. 80 cts., 5 lbs. $\$ 3.50$.

Prices of the following: Pkt. $5 \mathrm{cts}$., oz. $10 \mathrm{cts} ., 1 / 4 \mathrm{lb}$. 25 cts., lb. 75 cts., 5 lbs. $\$ 3.00$.

Pomeranian White Globe. Large, good both for table and stock.

Large White Norfolk. Globular, late, solid.

Yellow Aberdeen. Large globe-shaped table and stock variety.

Seven Top. This variety is grown altogether for its top. It does not make a root of sufficient size to eat. It is the best salad Turnip grown, and the tops will continue to come after being cut. Pkt. 5 cts., oz. 10 cts., 1/4 lb. 35 cts., lb. $\$ 1.25$, postpaid. Not prepaid, 10 lbs. $\$ 11.15$.

Southern Prize. Makes an abundant growth of tops, and at the same time produces a medium-sized root, which is white and of good quality." Pkt. 5 cts., oz. 10 cts., 1/4 lb. 35 cts., lb. $\$ 1.25$, postpaid. Not postpaid, 10 lbs. for $\$ 11.15$.

\section{RUTABAGA}

Large White, or Sweet Russian. Pkt. $10 \mathrm{cts.,} \mathrm{oz.} 15$ cts., $1 / 4$ lb. 35 cts., lb. 80 cts.

Improved Purple-Top Yellow. The sweetest and most productive of all the Rutabagas. This makes one of the best of Turnips for table use. Roots grow large, yellow and have a very sweet flesh. Pkt. 5 cts., oz. 10 cts., $1 / 4$ lb. 25 cts., lb. 75

1. Early Milan Purple Top. 2. Early White Flat Dutch. 3. Purple Top Strap Leaf. 4. White Egg.

5. Large Amber Globe. 6. Purple Top White Globe.
THE TURNIP SEED CROP is very short this ye a r; particularly the salad larly the salad varieties w 111
be unobtainable later in season. cts., postpaid. 5 lbs. $\$ 3.00$.

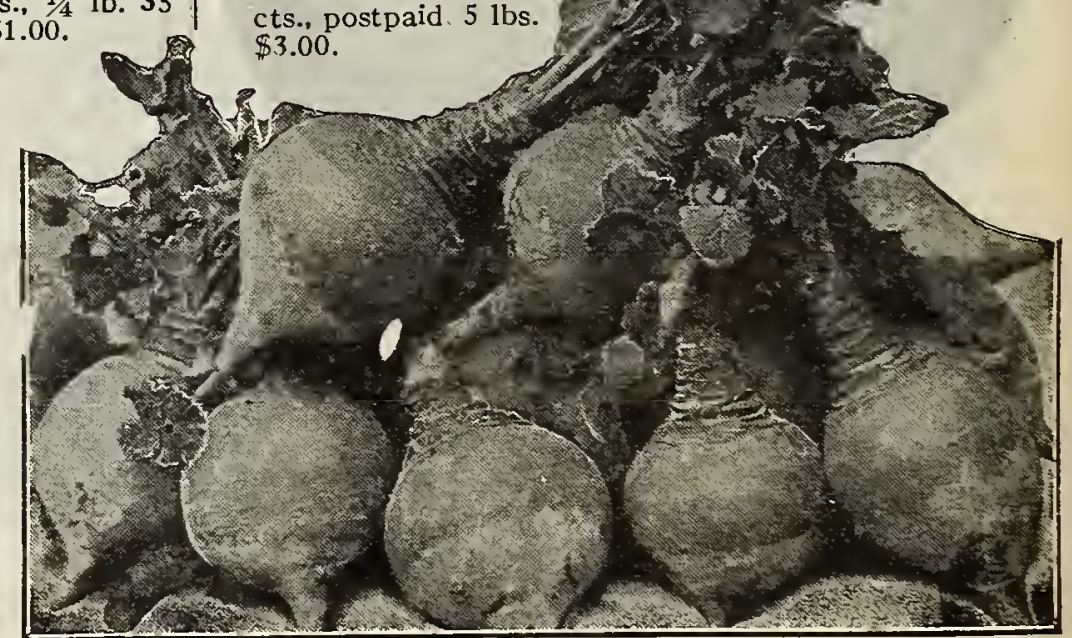

[30] 


\section{TOBACCO SEED}

Ore ounce will sow 50 square yards and produce aboul 7,500 planis

A very clean plece of land is best for the Tobacco plant beds; hence it is customary to burn a pieco of land in the woods for same. This destroys grass, weeds, and lnsects, adds fertility through the action of the wood-ashes, and leaves the ground in good order. The seeds aro sown about February and protected by plant-bed cloth to keep off ta bacco flies. When large enough and weather is settled (April-May-June), set the plants out in highly manured or fertilized soll in $3 \frac{1}{3}$ foot rows, 3 feet between the plants. Constant care must be given, cultivating, suckering, worming, etc. Methods of curing differ according to the variety and color, whether to be sun or lue-cured, etc.

Adcoek. One of the best Tobaccos for poor land. The leaf, though not long, is broad for its lengtli; they are set well apart on the stalk, exposing a greater surface to sun, resulting in a more uniform ripening and more even crop. Best adapted to light gray or sandy soils; makes fine cigarette cutters and smokers; cures bright. Pkt. 10 cts.. 0z. $50 \mathrm{cts.} 1 / 4 \mathrm{lb}$. $\$ 1.50$. post paid.

North Carolina Bright Yellow. Plants of medium size and very erect; leaf of medium lengtli and breadth. Cures well and is of unsurpassable quality. Oz. 50 cts., 4 oz. $\$ 1.50$. Ib. $\$ 4.00$, postpaid.

Improved Gold Leaf. A splendid combination of size; weight and quality. The leaf is long, broad, very similar to IVarne, but of finer texture and less inclined to have green shoulders. It has been thoroughly tried out by both growers and manufacturers, and has stood every test and proved one of the best of the bright Tobaccos on the market at the present time. Pkt. $10 \mathrm{cts}$. oz. $50 \mathrm{cts.}, 1 / 4 \mathrm{lb}$. $\$ 1.50$, postpaid.

Improved White Stem Oronoko. The plants are large. with long. medium broad leaves of handsome? shape. fine terture and good body. Oz. $50 \mathrm{cts} ., 40 z . \$ 1.50$ Ib. $\$ 4.00$. postpaid

Yellow Oronoko.

Yellow Pryor. Hlckory Pryor.

Conqueror.

Hester.

used in the Bright Tobacco Belt.

The above are largely used in the Bright Tobac
Prices: Pkt. $10 \mathrm{cts.,} \mathrm{oz.} 50 \mathrm{cts.} 4 \mathrm{ozs}$. $\$ 1.50$.

Warne. For bright wrappers this variety can be excelled only by the Gold Leaf. Grows to a large size and holds itself up well. The leaf is large, of medium breadth and very fine grained. Oz. $50 \mathrm{cts}$. \& oz. $\$ 1.50, \mathrm{lb} . \$ 4.00$. postpaid.

Long-Leat Gooch. Famous for its long, broad leaf of fine texture and superior quallty. Ranks among the first in the class where size does not injure quality" "Well known upon the market and brings top prices. Oz. 50 cts.. 4 oz. \$1.50, Ib. \$4.00, postpaid.

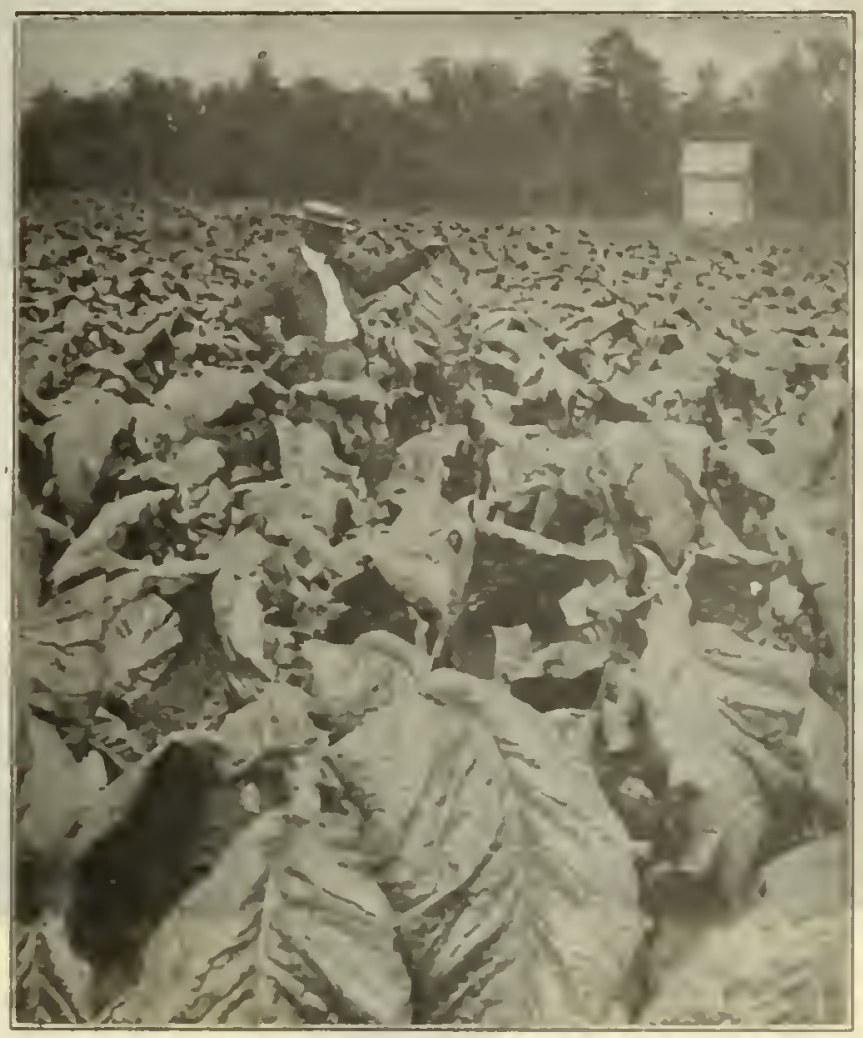

Improved Gold Leaf Tobacco.

\section{Wyatt's Hardy Everblooming Roses}

Antolne Rivolre. Soft peach flesh.

Columbia. Lively pink, almost thornless. Crusader. Rich crimson, fragrant. Duchess of Wellington. Saffron-yellow. Hadley. Dazzling crimson. pointed bud Jonkeer J. L. Mock. Deep pink. K. A. Victoria. Soft pearly-white. Los Angeles. Flame pink, coral and gold. Mrs. Aaron Ward. India yellow. Ophella. Salmon flesh.

Paul Nejron. Dark rose, immense flower.

Radlance. IVonderful pink.

Red Radlance. Bright cerise-red.

White Maman Cochet. White, and good bloomer.

Presldent Talt. Shell pink.

Frau Karl Druschkd. Pure white. Price, all Varietles:

Extra Strong Plants. $\$ 1.00$ each. $\$ 10.00$ per doz.

Strong Plants. $75 \mathrm{cts}$. each, $\$ 7.50$ per doz.

Large Specimen Plants. $\$ 1.75$ each.

\section{Climbing Roses}

Cumbinz American Beauty. Red.

Dr. W. Van Fleet. Shell pink.

Paul's Scarlet Climber. Scarlet.

Suver Moon. Wonderful whlte

Tausendschon. Pale pink.

Hoosler Beauty. Dazzling crimson-scarlet.

Cherokee Plnk. Rich pink.

Cherokee Red. Deep red.

Cllmblne Hadley. Crimson.

Climbing Sunburst. Golden.

Price, any of the above: $75 \mathrm{cts}$. each. $\$ 7.50$ per doz. Extra strong plants $\$ 100$ each.

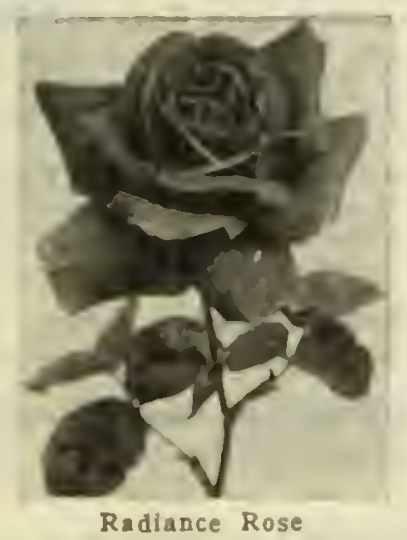

Nursery Stock

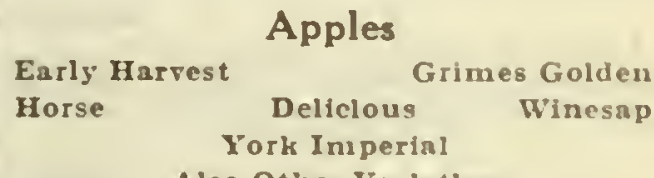

Also Other Varletles

Strong Trees. $75 \mathrm{cts}$. each. $\$ 5.50$ ner 10 .

\section{Peaches}

Leading Vinietles

Sirong Trees. 50 ets. cach, \$4,35 per 10

\section{Pears}

Leadlne Varletles

Strong Trecs. $\$ 1.00$ each, \$9.50 per 10 .

CHERRIES. Fach $\$ 1.25$; per 10

FIGS. Fach $75 \mathrm{cts}$, and $\$ 1.00$; per 10

PECANS. Each.

GRAPES (Bunch). Fach 25 cta. ; per 10 6.00 per 10 .

\section{Shrubs}

A bella Grandiflora. Each

Splrea Van Houttel Fach $75 \mathrm{cts}$. 10 for.

Crepe Myrtle. White. I'ink, Red. Each 75 cts. and I 50

Evergreens.

$\$ 1.25$ up

Send us your planting list for prices. 


\section{WYATT'S SELECTED FLOWER SEEDS}

\section{Will Make Your Home-Grounds More Beautiful}

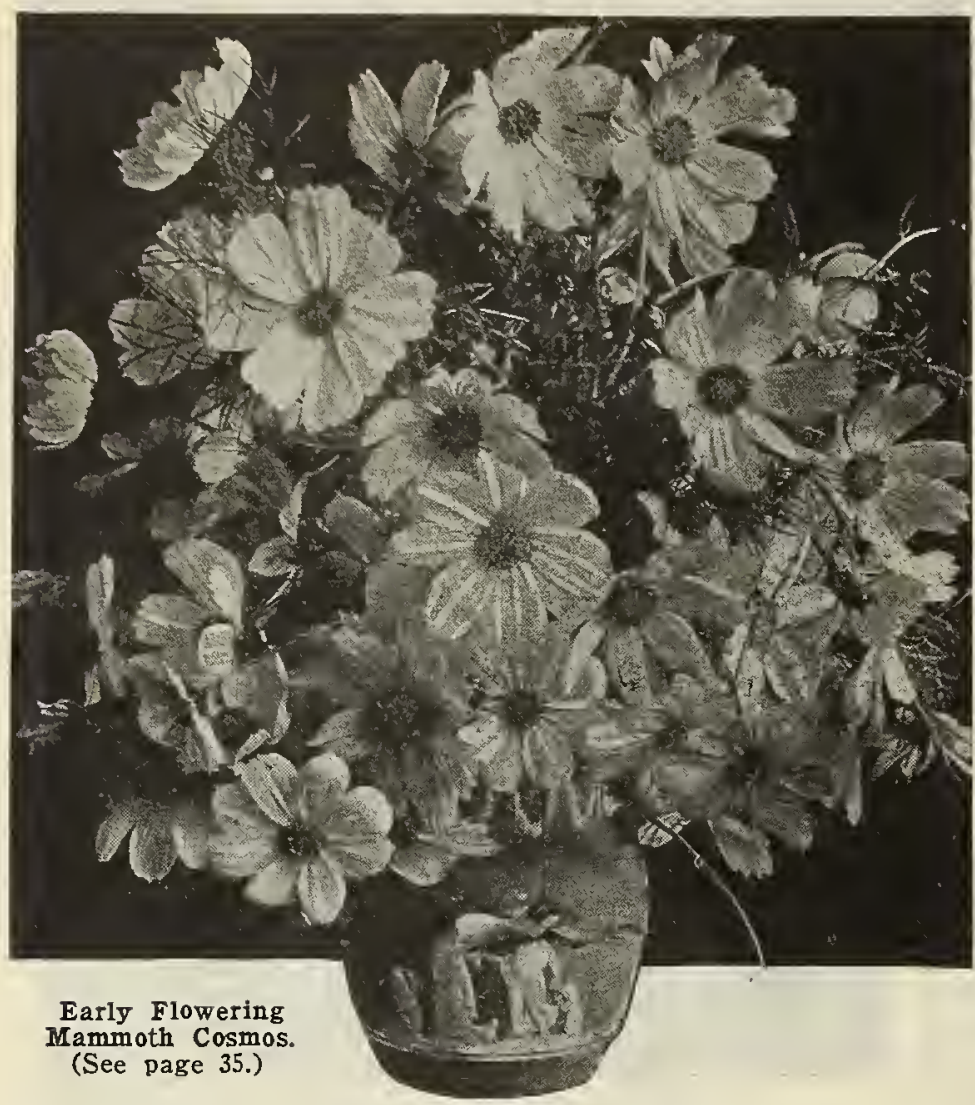

There are few places where some variety of flower seeds cannot be sown, and certainly, where there is any space at all, one should have flowers. For the beginner, we would suggest such kinds as Alyssum, Asters, Calliopsis, Centaurea, Cosmos, Nasturtium, Dianthus, Poppies, Verbenas, and Zinnias.

Light, rich loam is most suitable for flowers. The soil should be finely pulverized for best results. This is of paramount importance if one wishes to grow them successfully. They, in common with all other seeds, should be sown thinly and the soil pressed firmly over them when covered. Water frequently. A good plan is, sow the seeds in rows about 8 inches apart, then transplant to the permanent garden later. This applies to all the above varieties or those flowers to be sown from small seeds with the exception of Poppies, Nasturtiums and other large-seeded varieties, which can be planted where they are intended to flower, placing the seed about 2 inches apart in the rows and about 1 inch deep.

Annuals are those flowers that attain their full growth, bloom, and die the first year. Among these are Asters, Balsam, Cosmos, Zinnias, Mignonettes, Sweet Peas, Nasturtiums, Morning Glories and other brilliant and fragrant sorts.

Biennials produced from seed generally flower the second year and then die, the life of the plant being two seasons.

Perennials usually do not flower the first year, but live over until the second season and then bloom. They continue for many years after. These sorts constitute the "Hardy Flowers," such as Hollyhocks, Sweet William, etc.

Hardy, Half-Hardy, and Tender are common terms applied to Annuals. All Hardy Annuals can be sown at same time peas and radishes are usually sown in the vegetable garden. Halfhardy Annuals may be sown at corn-planting time, or when there is little danger of frost. Tender Annuals should not be sown until the ground is warm and the weather is settled, usually in May,

\section{Desirable Annuals for Beds and Massing}

Ageratum, Alyssum, Antirrhinum (Snapdragon), Balsams, Asters, Calendula, Calliopsis, Candytuft, Carnation, Celosia, Cosmos, Dianthus, Gaillardia, Heliotrope, Marigold, Chrysanthemum, Eschscholtzia, Nasturtiums, Pansy, Petunia, Mignonette, Scabiosa, Phlox Drummondii, Poppies, Portulaca, Salvia splendens, Zinnia, Verbena, and Vinca.

\section{Long-Stemmed Flowers for Cutting}

Aquilegia, Asters, Calliopsis, Carnations, Centaurea cyanus, Centaurea (sweet), Chrysanthemum, Coreopsis, Cosmos, Dahlias, Delphinium (hardy), Gypsophila, Gaillardias, Larkspur, Marigolds, Mignonette, Poppies, Salpiglossis, Scabiosa, Stocks, Stokesia, Sunflowers, Sweet Peas, Sweet Sultan, and Zinnias.

Climbing Annuals for Verandas, Arbors, Trellises, Etc.

Balloon Vine, Cobea, Cypress Vine, Gourds, Dolichos, Moonflower, Nasturtium, Morning-Glories, Thunbergia, Sweet peas, and Maurandya.

Desirable Plants for Shady Locations.

Antirrhinum, Canterbury Bells, Coreopsis, Digitalis, Pansies, Mimulus, Poppies (hardy), Violet, Aquilegia, Asperula, Daisies, and Delphinium.

\section{Plants Suitable for Edging and Low Borders.}

Aster, Ageratum, Alyssum, Begonia, Bellis (Daisies), Candytuft, Centaurea candidissima, Cosmos (dwarf), Lobelia compacta, Marigold, Pinks (hardy), Portulaca, Pyrethrum, Forget-me-not, Verbenas, and Zinnias.

\section{Plants for Baskets, Vases, Veranda Boxes, Etc.}

Alyssum, Abronia, Centranthus, Dusty Miller, Centaureas, Clarkia, Dwarf MorningGlory, Lobelia gracilis, Maurandya, Nasturtium, Petunia, Begonia, Coleus, Fuchsia, Geranium, Heliotrope, Impatiens, Pansy, Oxalis, and Thunbergia.

\section{Showy Annuals for Tall Beds, Groups and Backgrounds.}

Cosmos, Centaurea, Datura, Hibiscus, Amaranthus, Marigolds, Poppies, Nicotiana, Ricinus, Salvia, Sunflower, Zinnias, Calendula, and Calliopsis.

\section{Annuals to be Started in Boxes Early.}

Cosmos, Godetia, Marigolds, Canterbury Bells, Calliopsis, Chrysanthemum, Cockscomb, Petunia, Ricinus, Verbena, Sweet William, Asters, and Salvia (Scarlet Sage). These can also be planted in the open when weather permits.

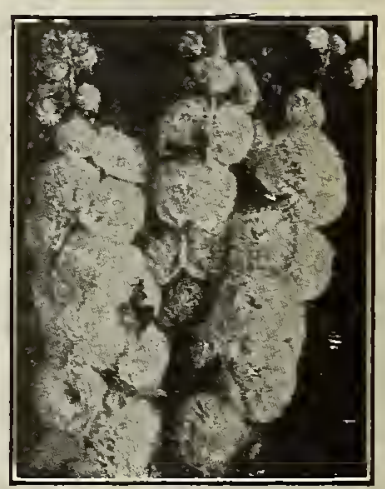

Double Mixed Hollyhocks

(See page 36.) 


\section{WYATT'S ASTERS}

The Aster is the queen of the late summer flowersit is equally good for cut-flowers and for bedding. IVyatt's varieties are all of the fine large American kinds with flowers 4 to 5 inches across. An Aster bed is a mass of color, from white through delicate pinks to rich red and from palest lavender to deepest purple. Sow Aster seed in boxes in January and transplant to the garden about April 1 to 15. or sow in the open in April.

\section{WYATT'S MAMMOTH ASTERS} Twisted Petal Type

Mammoth Asters have petals just a little broader than Crego's and less twisted. They have fine large flowers, over 4 inches across and sometimes 5 inches, borne on long stems. They are entirely new and different from all of the other Asters, and have a great charm in the delicacy of their flowers.

Mammoth White

Mammoth Shell-pink Mammoth Lavender

Pkt. 15 cts., $1 / 4$ oz. 60 cts.

Mixed Asters. Pkt. $10 \mathrm{cts} .1_{1}^{1}$ oz. $40 \mathrm{cts..} \mathrm{oz.} \$ 1.00$.

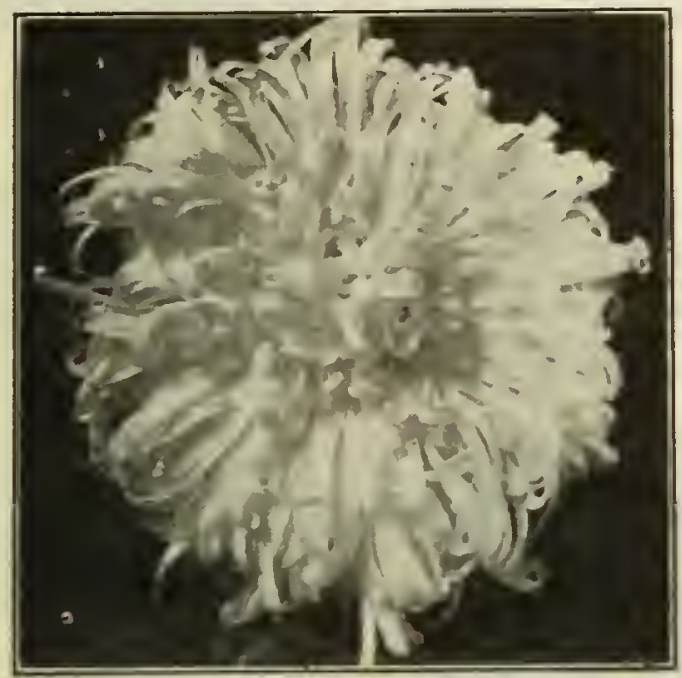

Wygatt's Mammoth Twisted Petal Aster.

\section{WYATT'S PEONY-FLOWERED}

The improved strains of this grand Aster are considered the finest in cultivation. The large, perfectly double flowers are fine. Height, 2 feet. Fine assortment.

Mixed Colors. Pkt. $10 \mathrm{cts} .1 / 8 \mathrm{oz} .40 \mathrm{cts}$.

\section{AMARANTHUS}

These plants grow 2 to 3 feet tall and have ornamental foliage as well as flowers. The seed is very fine. but grows readily if kept moist. Can be readily transplanted. Do not cover seed over a quarter of an inch. Hardy annual. Candatus (Love-lies-bleeding). Long, drooping sprays of red flowers. Pkt. $10 \mathrm{cts.s} 3 / 2 \mathrm{oz} .20 \mathrm{cts}$.

Tricolor (Joseph's Coat). V'cry

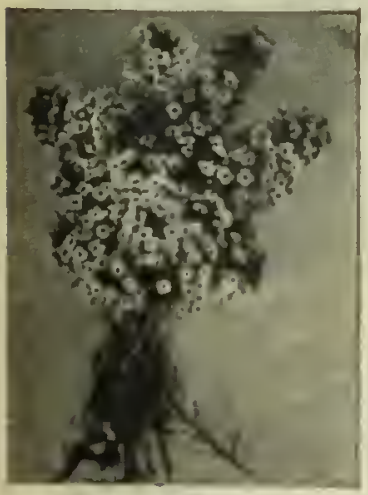

Sweet Alyssum. fine variceated foliace. Pke. $10 \mathrm{cts}$. 1 , $\mathrm{Oz} .20 \mathrm{cts}$.

\section{AL YSSUM}

A wonclerfully hardy litcle plant, coming into bloon when only a couple of inches high and flowering all the summer. Grows about 6 inches high and is fine for edging beds.

Carpet of Snow. An exceptionally fine and compact variety. Pkt. 10 ctg., 1/ oz. $20 \mathrm{cts} .1$. $\mathrm{h}$ oz. $35 \mathrm{ctg} . \mathrm{oz}$. $65 \mathrm{cts}$.

Sweet Alyssum. The regular type: gtrong grower; free liloomer. Pkt. $10 \mathrm{cts} . . \mathrm{oz}$. 65 cta.
Semple's Giant Late-Branching.

\section{SEMPLE'S GIANT LATE-BRANCHING}

Without question, the finest Aster grown. It has size. vigor, fine stem, beauty of form and varicd color to recommend it, and, while not so early as many of the other varieties, it stands at the head of the list.

Finest Mixed Colors. All shades and colors. Pkt. 10

cts., $1 / 8$ oz. $30 \mathrm{cts}$.

Lavender. Pkt. $10 \mathrm{cts} .1 / \% \mathrm{oz} .40 \mathrm{cts}$.

Royal Purple. Pkt. $10 \mathrm{cts} .1 / 3 \mathrm{oz} .40 \mathrm{cts}$

Pure White. Plit. $10 \mathrm{cts} .1 / \mathrm{s} \mathrm{oz} .40 \mathrm{cts}$.

Crimson. l'kt. $10 \mathrm{cts} .1 / 5 \mathrm{oz} .40 \mathrm{cts}$.

Shell-Pink. Pkt. $10 \mathrm{cts} .01 / 5 \mathrm{oz} .40 \mathrm{cts}$.

Collection of Semple's Giant Asters, 5 above sorts, 40 cts.

\section{CREGO ASTER}

The Crego comes into bloom just ahead of the Latebranching Asters, and being of Comet type, affords variety in the sarten.

Purple. Rich purple. Pkt. $10 \mathrm{cts} .1 / 8 \mathrm{oz} .40 \mathrm{cts}$. White. Pure white. Pkt. $10 \mathrm{cts} .1 / 8 \mathrm{oz} .10 \mathrm{cts}$. Pink. Beautiful pink. l'kt. $10 \mathrm{cts} .15 \mathrm{oz}, 40 \mathrm{cts}$

Lavender. Rich. P'kt. $10 \mathrm{cts} .1 / 6 \mathrm{oz} .40 \mathrm{cts}$.

Crego's Giant Crimson. Pkt. $10 \mathrm{cts} .1, \mathrm{k}$ oz. $40 \mathrm{cts}$

Mixed. All colors. P'kt. $10 \mathrm{cts} .1 / 60 \% 30 \mathrm{cts}$.

Collection of Crego Asters, 1 pkt. each above 6 colors $45 \mathrm{cts}$.

\section{QUEEN OF THE MAR - KET ASTER}

Very early. White, pink, lavender. scarlet, dark blue. and choice mixed. Pkt. 10 cts. $\mathrm{oz} . \$ 1.50$.

\section{AQUILEGIA}

(Columbine)

This is one of onr finest lyardy perenuials, flowering the second yeat from seed and worthy of a place in every carden. Seed krows rearlily. but is slow in startiug.

Single or Double Mixed. All

colors. Pkt. $10 \mathrm{cts}$. i $_{4} \mathrm{Oz} .25$

cts., 1 oz. $75 \mathrm{cts}$.

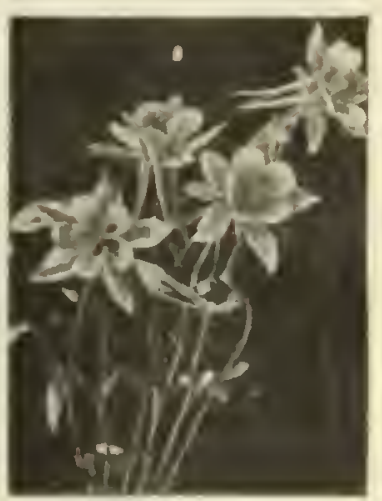

Columbine.

\section{AGERATUM}

An annual plant, growing about a foot high and covererl all sumuner with close, fluffy heads of bloom of a pretty shade of bluc. Used largely for edgings and borders of taller-growing plants. Hardy annual.

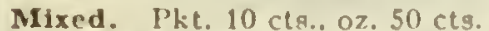

Imperial Blue. Pkt. $10 \mathrm{cts}$, is oz. $25 \mathrm{cls}$ 


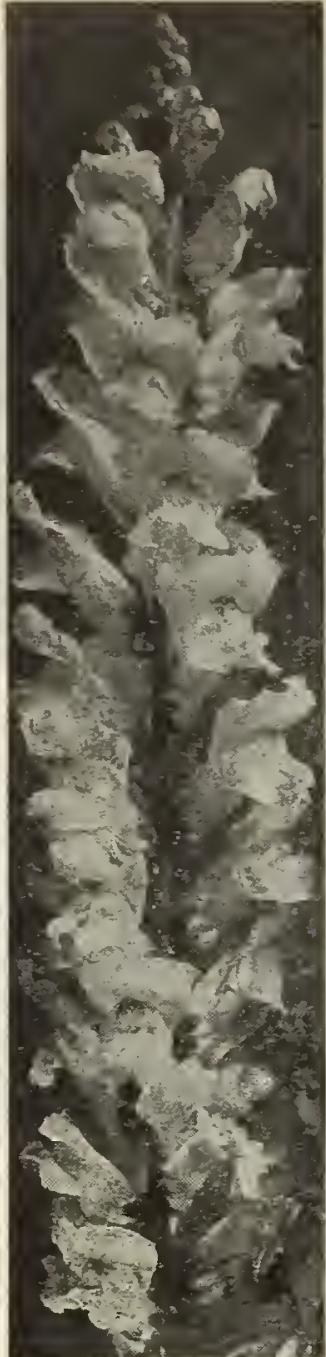

Giant Snapdragon.

\section{ANTIRRHINUM}

(Snapdragon)

This is a well-known and valuable plant, bearing long spikes of many colored flowers throughout the season. A hardy annual but sometimes lives over to the second year. Seed rather slow to sprout.

Giant Mixed. Pkt. 10 cts., oz. $\$ 1.00$.

\section{BALSAM}

Sometimes called "Touch-menot," or "Lady's Slifier." A tender annual, growing about 18 inches tall in the shape of a small tree and producing all along the branches showy single and double flowers like small roses.

Double Mixed. Pkt. $10 \mathrm{cts.,}$ oz. $75 \mathrm{cts}$.

\section{BALSAM PEAR AND APPLE}

A good climber, with dense foliage and oddly shaped fruit, which is claimed to have mechanical qualities when put in alcohol. Height 10 feet. Halfhardy annual. Pkt. 10 cts., oz. 35 cts.

\section{BALLOON VINE}

A rapid grower with fine flowers, followed by inflated seedpots resembling small balloons. Half-hardy annual. Height 10 feet. Pkt. $10 \mathrm{cts.}, 0 z, 35 \mathrm{cts}$.

\section{BELLIS}

(English Daisy)

A little old-fashioned plant. growing about 4 inches tall and used for edging. produces very double pink and white flowers in early summer. Hardy perennial. Pkt. 10 cts., $1 / 8$ oz. 50 cts.

\section{CALENDULA}

The old "Pot Marigold". A very hardy annual with double yellow flowers, like double daisies. Blooms all summer and grows about 15 inches tall. Hardy annual. Pkt. 10 cts., oz. 35 cts.

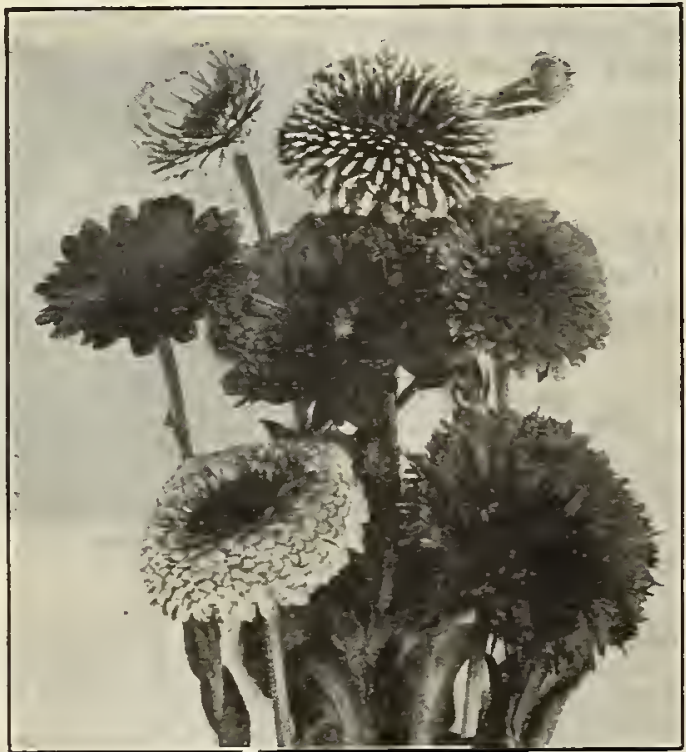

Calendula.

\section{CALLIOPSIS}

Very hardy and showy annual with bright yellow and reddish brown single daisy-like flowers, easily grown and useful both for garden decoration and cutting.

Tall, Mixed Colors. Pkt. $10 \mathrm{cts.}$ oz. $35 \mathrm{cts}$.

Dwarf, Mixed Colors. Pkt. 10 cts.. oz. 35 cts.

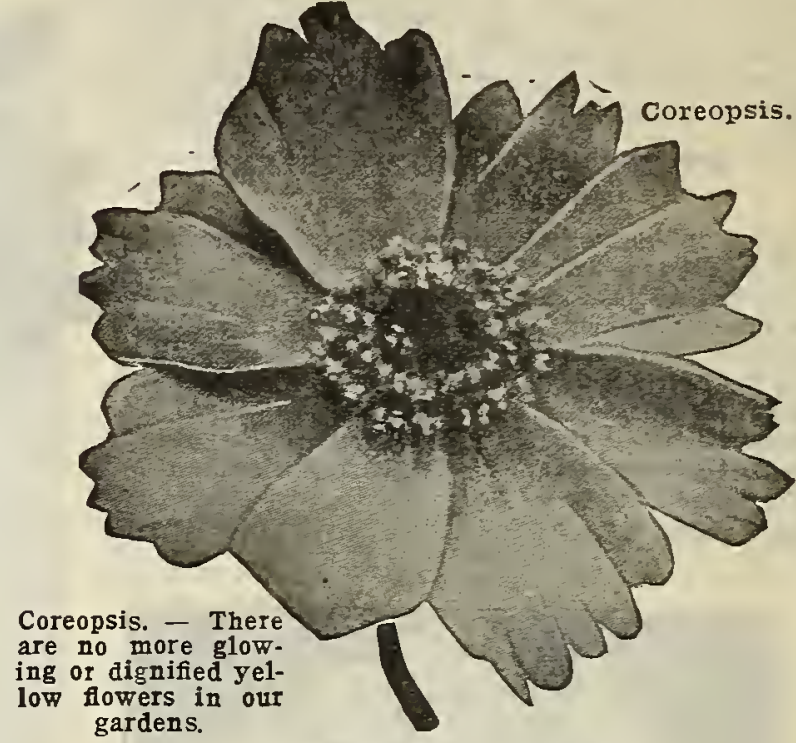

COREOPSIS (Tickseed)

One of the most popular hardy plants, the flowers are a rich golden yellow of a beautiful graceful form and bloom June to October.

California Sunbeam. $2 \mathrm{ft}$. Large orange-yellow flowers on long gracefin stems. About the best yellow cutflower

blooming incessantly. Pkt. $10 \mathrm{cts}, 1 / 1 \mathrm{oz} .25 \mathrm{cts}$. Plants. 3 for $50 \mathrm{cts}$., doz. $\$ 1.75,100, \$ 12.00$.

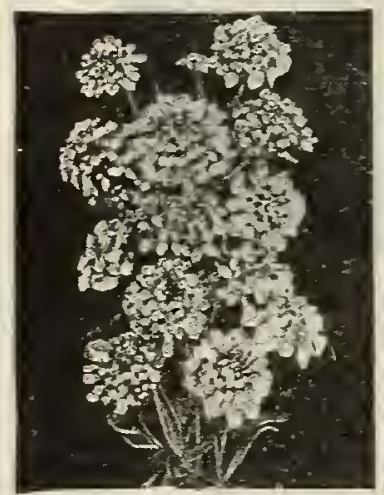

Candytuft.

\section{CAND YTUFT}

A free-flowering, hardy annual, somewhat resembling Alyssum, but larger, with longer heads of bloom, fragrant and easily grown.

Mixed Colors. Pkt. 10 cts. oz. $35 \mathrm{cts}$.

\section{CAMPANULA}

(Canterbury Bells)

Grows about 2 feet high and blooms in early summer. Will flower well in the shade. This is a true biennial. Does not bloom the first year, and after flowering the second year dies. Colors White, Pink, Blue and Purple, in fine mixture.

Single or Double. $\mathrm{Pkt}$ z cts., $1 / 4$ oz. 30 cts., oz. $\$ 1.10$

\section{CENTAUREA}

There are two types of thi plant, one Centaurea gymnocarpa, or Dusty Miller, a plant with silvery gray foliage and largely used for bordering formal beds, and the other, our old-fashioned Bachelor's Button, or Cornflower, Centaurea cyanea, which is a very hardy annual, flowering all summer and useful for cutting. Very easily grown.

Gymnocarpa. Pkt. 10 cts. oz. 50 cts.

Cyanea. Mixed Colors. Pkt.

10 cts., oz. 50 cts.

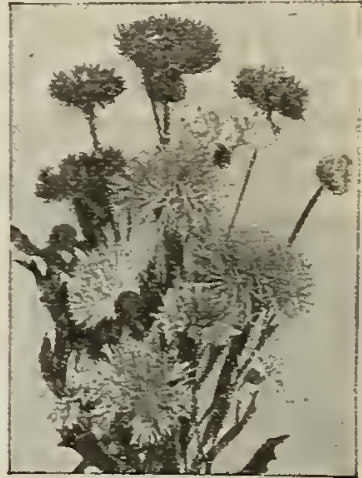

Centaurea Cyanea.
GIANT.FLOWERING SWEET SULTANS (Centaurea imperialis)

The blooms are borne on long stems. Of the easiest growth; very showy in the garden all summer long. Giant Mixed Colors. An elegant assortment of colors. Pkt. 10 cts., 1/4 oz. 25 cts., oz. 75 cts. 


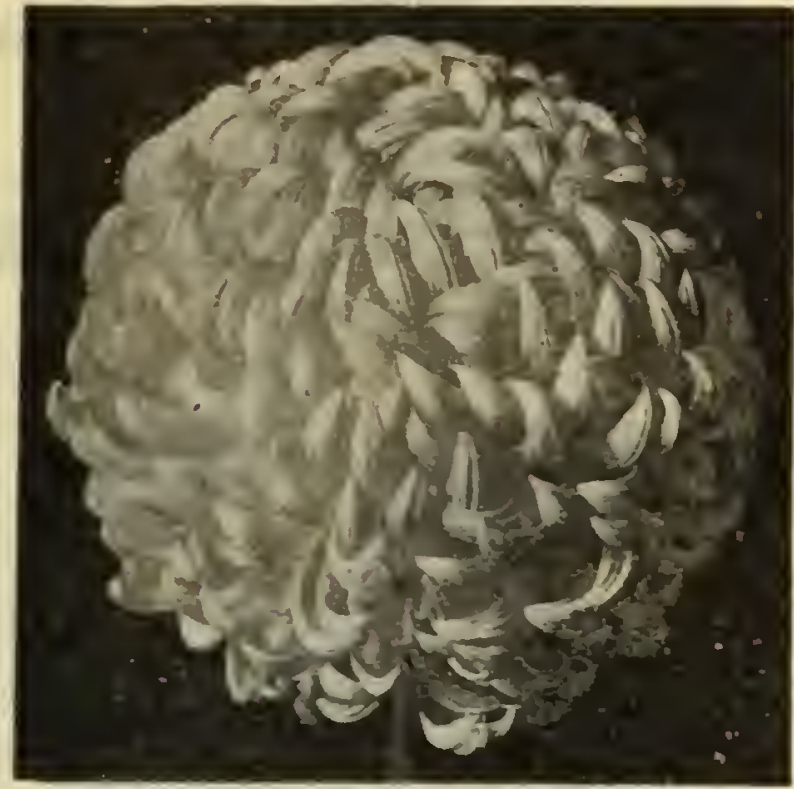

\section{CHRYSANTHEMUMS}

(Annual Varietles)

The following hardy annuals are summer-flowering border plants (growing abollt 2 feet high), bearing in pro fusion daisy-like flowers averaging about 3 inches acros. on cood stems, and quite distinet from the hardy pereunia and autumn-thwering varieties.

Single Mired. (Painted Daisies). Many colors. I'kt $10 \mathrm{cts.}, 1 / 2 \mathrm{oz}, 40 \mathrm{cts}$.

Coronarium, Double Mixed. Yellow, white, ctc. Pkt $10 \mathrm{cts} ., 02.75 \mathrm{cts}$.

Mired. The choicest carinatum and coronasium valictics. both single and double. Pkt. $10 \mathrm{cts}$. $1 . \mathrm{oz} .25 \mathrm{c}$

\section{CHRYSANTHEMUM PLANTS}

Extra Selected Varieties. Larec fluwerine or pompoms. Yellow, Golden, Cream, llhice, Bronze, l'iuk, Lavender. $60 \mathrm{cts}$. per dozen, postpaid. \$t.00 per 100.

\section{CLARKIA}

This precty aucl casily grown annual has becn much improved in recent vears. They do well cither in sun or shade, growing 2 to 21 , feet ligh, with leafy raccines of double tlowers. which all open in water when cut.

Elegans Double Mixed. A

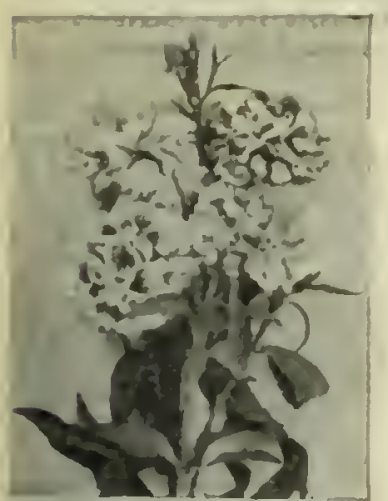

Dlanthus tinc mixture containing all the enlors. Pkt. $10 \mathrm{cts..}$ lí oz. $25 \mathrm{cts}$.

\section{CYPRESS VINE}

One of the prettiest of our smaller vines, with fine. feathery dark green foliage audl star-shaped scarlet and Hhite flowers. llicight of feet. Pkt. $10 \mathrm{cts}$. oz. $45 \mathrm{cts}$.

\section{DIANTIUS}

lime liecte plants with tlowor reserulling Caruations. liery harry and nsually" live over fur several yours, but blonin frevely the first year. (Ine of the easiest flowers to grom.

Chlnese Fl.-Pl. Double C'hinese P'inks. A very attract ive variety: Mixed colors. Pke. $10 \mathrm{cts}, 0 \%, 70 \mathrm{cts}$.

Everbloomlng. l'kt. $10 \mathrm{cts}$, \& $_{1} 02.30 \mathrm{cts}$.

DOLICHOS (IIyacinth Bean)

A free-growing rlimber wleh heavy foliage aud large

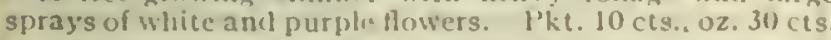

For Aphis Use Black Leaf-40, 35c. a Bottle.

\section{CARNATIONS}

Have a delightful clove fragrance. Half-hardy perennials, flowering the second year from sccd, with exccption of the "Margueritc" variety, which will bloom in four months from timc of sowing seed. Should not be planted where water stands in winter.

Mixed Colors. Pkt. $10 \mathrm{cts.,} \mathrm{1'4} \mathrm{oz.} 30 \mathrm{cts}$, oz. $\$ 1.00$.

Marguerite. All colors. Pkt. $10 \mathrm{cts}$., 1/4 oz. $40 \mathrm{cts}$.

\section{CELOSIA (Cockscomb)}

Hardv annuals, producing peculiar heads of bloom rather resembling a cock's comb, hence the nanc.

Glasgow Prize. The fiucst of all, producing immensi heads of glowing crimson. Pkt. $10 \mathrm{cts} .1 / 3 \mathrm{oz} .35 \mathrm{cts}$.

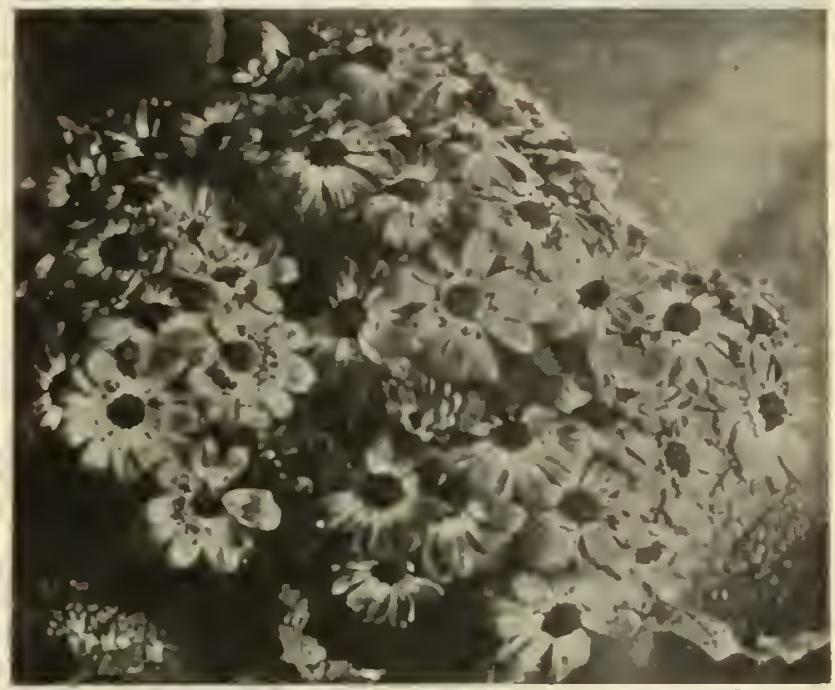

Alricun Dasy.

\section{AFRICAN DAISY (New Hybrlds)}

The blouns of these New llybids if the foulden Orange African Daisy comprise a wonclerful "ariecty of beautiful and delicate shades of color, ranging from pure white through pale salinon and primrose tones to deepest orange. ['kt. $10 \mathrm{cts.} 3$ pkts. $25 \mathrm{cts.}$ 1 \& 0 z. $40 \mathrm{cts}$.

\section{COLEUS}

The most popntar of all fuliage plants. Easily grown froin secel. but must be started in a box in the hollse or hocbed, as the seed is very fine and when sown is scarcely covered, but must be kepe moist. Tender ammual.

Mixed Colors. l'kt. $15 \mathrm{cts}$, ts $0 \mathrm{z} .85 \mathrm{cts}$

\section{Cosmos}

Onc of our most satisfactory hardy ammuals, flumcrime in late sumuner. lïine for culting and e'asily grown. Grows \& to o fect high.

Early-Flowering Mammoth. (Sere illustration, page 32) This imfroved variety has tluwers fully as large as the later egye, but begins to flewer in Julv, and from that time on to frost yichls a quamtity of blesum. Pkt. 10

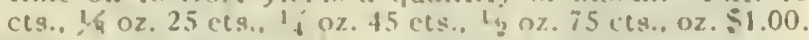

Double Cosmos. (Sec page 4 ).

\section{ANNUAL LARKSPUR}

Tall Stock-flowered. White. Tall Stock-flowered. Shell-pink 10 "

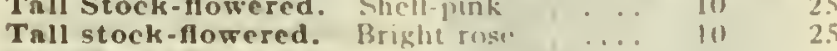
Tall Stock-Flowered. Dark blut .... II

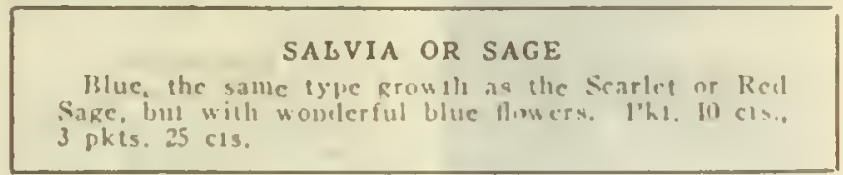

\section{DIBBLES}

for transplantiug $75 \mathrm{cts}$ e each

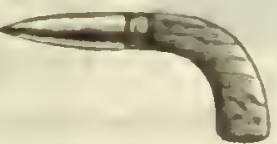

Turf Edgers

Fach $\$ 1.50$. 


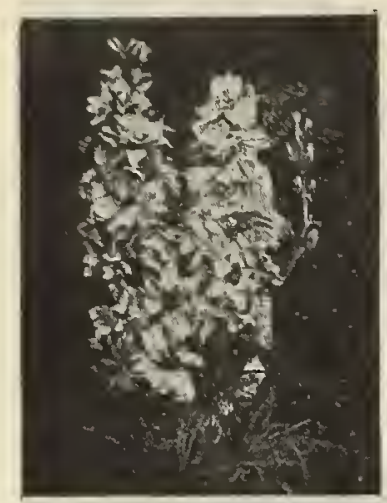

Larkspur.

\section{DELPHINIUM}

(Larkspur)

Very showy plants, producing long spikes of beautiful flowers in various shades of blue. There are both annuals and perennials.

Giant Hyacinth-Flowered. Hardy annual. All colors. Sow early as ground is in working condition. Pkt. 10 cts., $1 / 4$ oz., 30 cts., $1 \mathrm{oz}$. $\$ 1.00$.

\section{DIGITALIS (Foxglove)}

Produces long spikes of pink, light purple, and white, túbeshaped flowers. Does well in the shade. A very stately plant easily grown, and should be in every garden. Biennial. Pkt. 10 cts., $1 / 4 \mathrm{oz} .30 \mathrm{cts}$.

\section{DAHLIAS}

The double sorts will bloom the first season if the seed is sown before the beginning of April; the single sorts will bloom from seed sown in the open ground as late as June, although an earlier start is better.

Single Mixed. All colors. Pkt. $10 \mathrm{cts} ., 1 / 4 \mathrm{oz} .25 \mathrm{cts}$.

Double Mixed. This ty pe is very desirable. Many colors.

Pkt. $10 \mathrm{cts} .1 / 8$ oz. $40 \mathrm{cts}$.

\section{ESCHSCHOLTZIA (California Poppy)}

A hardy, free-flowering annual, growing about. 15 inches high and producing quantities of single, poppy shaped blooms in shades of yellow, orange and red. Flowers over a long period. Pkt. $10 \mathrm{cts.,}$ oz $30 \mathrm{cts}$.

EUPHORBIA VARIEGATA (Snow on the Mountain)

A favorite for mass planting. Showy and distinct plants with very attractive foliage, dark green leaves. edged clear white. 2 feet. Easily grown from seed, doing well in any fairly good soil. Pkt. 10 cts., $1 / 4 \mathrm{oz}$. 25 cts., oz. 75 cts.

\section{GAILLARDIA}

A perennial producing large, single, daisy-shaped flowers in shades of yellow and reddish brown, with brown centers; fine for cutting. One of the most persistent bloomers. Does best in the hottest, driest location. Pkt. 10 cts., 3 pkts. for 25 cts., $1 / 4$ oz. 30 cts.

\section{GLOBE AMARANTH}

When fully developed and hung head down in a cool dry place for a few days, they will keep their form and color for many months. Hardy annual. Pkt. $10 \mathrm{cts} ., 1 / 4 \mathrm{oz} .20$ cts.

\section{HELIOTROPE}

Always popular on account of its delightful fragrance. The seed is rather slow in starting and had best be sown in boxes or in a hotbed. While it is a perennial, it will not stand any frost, and it is therefore started afresh each year unless one cares to remove the plants to the house before frost comes. Can be started from cuttings.

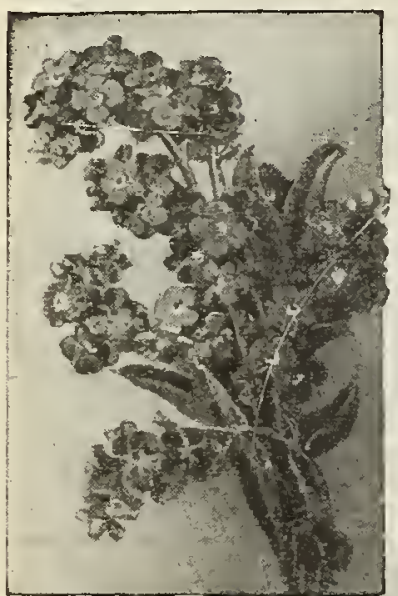

Forget-Me-Not.
Mixed Colors. Pkt. 10 cts., $1 / 4$ oz. 40 cts. FORGET-ME-NOT (Myosotis)

Charming little flowers, highly effective if grown in masses. If sown early in sunny border, will bloom the first season. Height 6 to 9 inches. H. P.

Mixed Colors. The finest varieties mixed. Pkt. 10 cts., $1 / 8$ oz. 20 cts., $1 / 4$ oz. $35 \mathrm{cts}$.

\section{GODETIA}

(Satin Flower)

Beautiful and easily fusion of flowers, satiny texture.

Tall or Dwarf. Pkt. 10 cts., $1 / 8 \mathrm{oz} .20 \mathrm{cts}$. grown, producing a pro-

Perennial Plants. All kinds in season. $\$ 2.50$ doz., postpaid. Send us your list for prices.

\section{GOURDS}

Very rapid-growing vines, producing odd and interesting fruit.

Nest Egg. Pkt. 10 cts., oz. 25 cts.

Dipper. Pkt. 10 cts., oz. 25 cts.

Small Varieties, Mixed. Pkt. 10 cts. $0 z .25$ cts.

\section{HELICHR YSUM (Eternal Flower)}

Everlasting; cut when about to open and dry for winter bouquets; large, double and of many colors. Pkt.10 cts., $1 / 4$ oz. 20 cts.

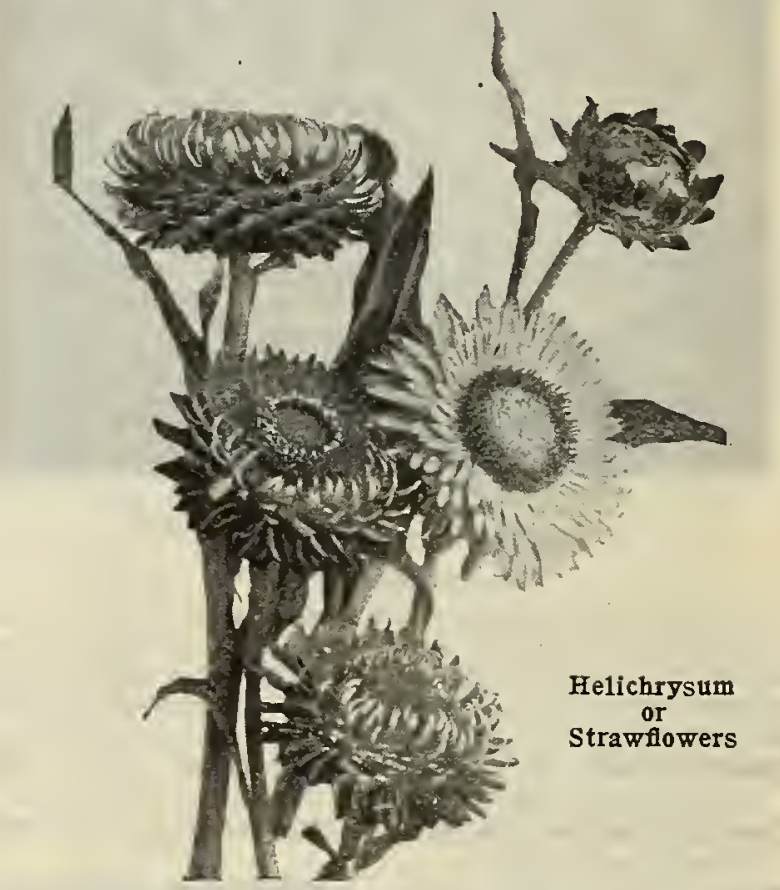

HIBISCUS (Marshmallow)

Showy Ornamental perennial plants for mixed beds or shrubbery borders, having large-sized beautifully colored flowers. Pkt. 10 cts., $1 / 2$ oz. 30 cts.

\section{HOLL YHOCK}

(See illustration, page 32).

Their long spikes of many-hued flowers add a quaint touch to any flower-garden and are invaluable where it is desired to hide high fences. There are both single and double varieties and they vary in color from white to deepest garnet, and include many lovely shades of yellow. Choice Mixed. All varieties. Pkt. 10 cts., oz. $\$ 1.00$.
Newport Pink

Double Salmon-Rose

Double Apple Blossom

Pkt. 10 cts., $1 / 4$ oz. 35 cts.

\section{JOB'S TEARS}

\section{(Coix Lacryma)}

A grass-like annual, producing large, shiny seeds. used for many purposes. Hardy annual. Pkt. $10 \mathrm{cts}$., oz. 20 cts., $1 / 4$ lb. 30 cts.

\section{KOCHIA}

(Summer Cypress)

A remarkable annual, producing dense, rounded plants with fine green leaves and growing to a height of 3 feet. The foliage changes to a reddish shade toward fall. Fine for a hedge or to outline the garden. Pkt. $10 \mathrm{cts.,} \mathrm{oz.} 40$ cts., postpaid.

\section{Double Yellow Double Deep Scarlet Annual Hollyhock}

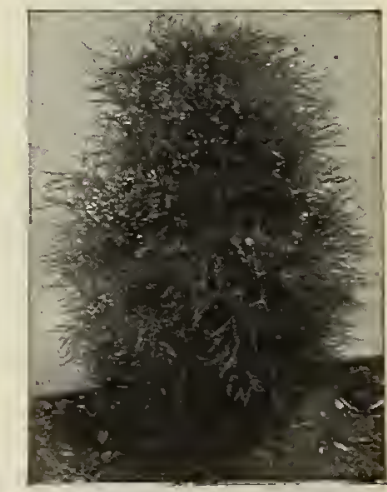

Kochis. 


\section{LOBELIA ERINUS (gracilis)}

Bright Bluc. Pkt. $10 \mathrm{cts}$.

\section{LOBELIA Cardinalis}

(Indian Pink or Cardinal Flower)

Thrives best in moist and slightly shaded positions. The flowers are rich crimson. Height 2 to 4 fcct. Pkt. $15 \mathrm{cts} ., 1-32 \mathrm{oz}, 60 \mathrm{cts}, 1-16 \mathrm{oz}$. $\$ 1.10,1 / \mathrm{s} \mathrm{oz} . \$ 2.00$

\section{LUPINUS (Lupine)}

Lupines are extremely decorative in the garden and valuable for cutting.

Annual Mixed. One to two feet ligh, with upright racemes of variously colored, pca-shaped flowers. Valuable for mixed flower-bcds and borders. Pkt. $10 \mathrm{cts}$. oz, $25 \mathrm{cts}$.

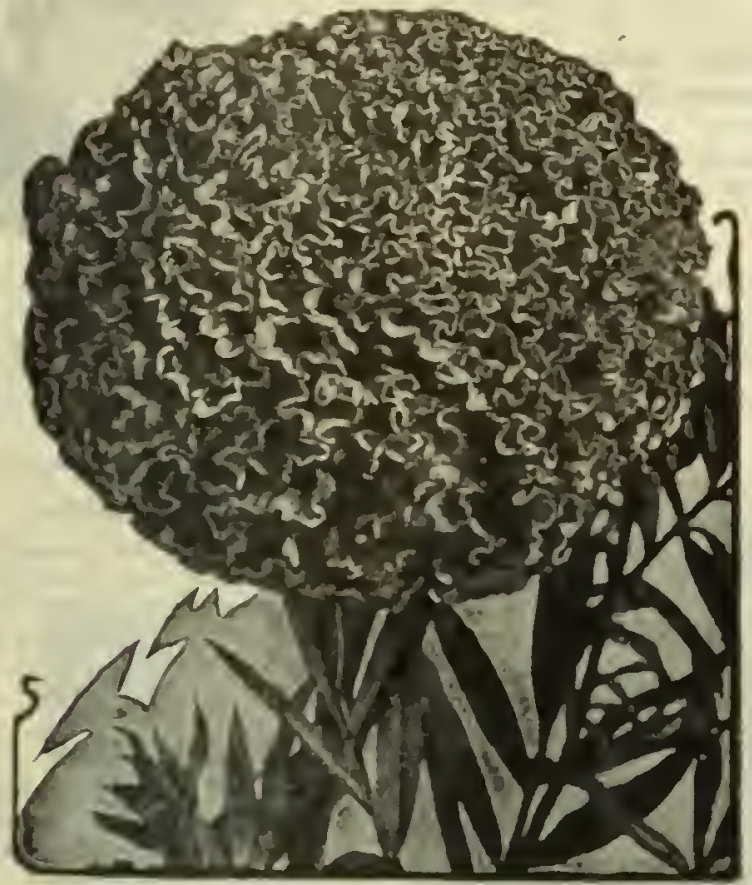

Orange Prince Marigold.

\section{MARIGOLD}

One of the easiest grown annuals, furnishing all summer long quantities of double and single flowers in shades of yellow and orange-some being striped with brown.

French Gold-Striped. Pkt. $10 \mathrm{cts} ., 0 z .50 \mathrm{cts}$.

African Double Mixed. Pkt. $10 \mathrm{cts} ., 0 z .50 \mathrm{cts}$.

Tall French Double Mlued. Pkt. $10 \mathrm{cts.,} \mathrm{1/2} \mathrm{oz.} 30 \mathrm{cts}$.

Orange Prince. l.arge perfect doublc-quilled flowers of

a rich deep golden-orange color. Pkt. $10 \mathrm{cts}, y_{4}$ oz. 50 cts., oz. $\$ 1.50$.

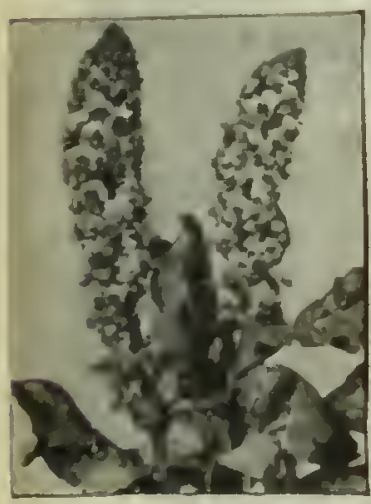

Mtrnonette.
Lemon Queen. A connterpart of Urange Prince cxcept in color, which is a soft lemon-y.ellow. I'kt. $10 \mathrm{cts}$, l's oz. 50 cts., oz. $\$ 1.50$.

\section{MIGNONETTE}

Very popular on account of its delightful fragrance. A very hardy annual, and should be sown soon as the ground can be worked. Does not transplant, and should be thinned to stand 6 inclies apart.

Sweet. The coinmon varícty. Pkt. $10 \mathrm{cts.} 15 \mathrm{oz} .15 \mathrm{cts}$ oz. 25 its.

Machet. A very choice largeflowered type. I'kt. $10 \mathrm{cts}$. oz. $40 \mathrm{cts}$.

\section{MARIBILIS}

(Marvel of Peru)

The well-known Four o' Clock. Grows freely and flowers quickly from seed. Blooms from late afternoon on through the night. Very fragrant. Roots can be taken up and stored like dahlias, but seed is very cheap and starts readily. Hardy annual.

Mired Colors. Pkt. $10 \mathrm{cts}$. $0 z .25$ cts.

MORNING GLORX

Imperial Japanese. Very pretty foliage and a great variety. of colors in the bloom. Sow in a sunny location and give plenty of water. Pkt. $10 \mathrm{cts}, 0 \mathrm{z}, 40 \mathrm{cts}$

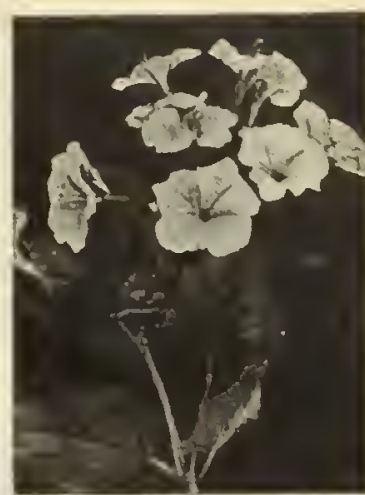

Maribilis. Marvel of Peru.)
Common Morning Glory. (Convolvulus major). All colors, finely mixed. Very popular. Pkt. $10 \mathrm{cts} ., 0 z$. $20 \mathrm{cts} ., 1 / 4 \mathrm{lb} .30 \mathrm{cts}$.

\section{MOONFLOWER (Evening Glory)}

A rapid grower, climbing some 20 fcet in a season, and producing large, waxy white flowers, similar to morning glories, 4 to 6 inches across. Very fragrant and opening about $70^{\circ}$ clock in the evening. The seed is very hard and the shell should be chipped or filed until the white seed shows through and then soaked in warm water for half a day before sowing. Pkt, $10 \mathrm{cts} .1 / 1 \mathrm{oz} .25 \mathrm{cts}$.

\section{NICOTIANA}

A very popular plant, with fragrant, white, star-shaped flowers. Sometimes called "Flowering Tobacco." Pkt. $5 \mathrm{cts} .1 / 802.75 \mathrm{cts}$.

Sanderae Hybrids. An improved type witl many delicate shades of color. Pkt. $10 \mathrm{cts.}, 1 \% \mathrm{oz} . \$ 1.00$

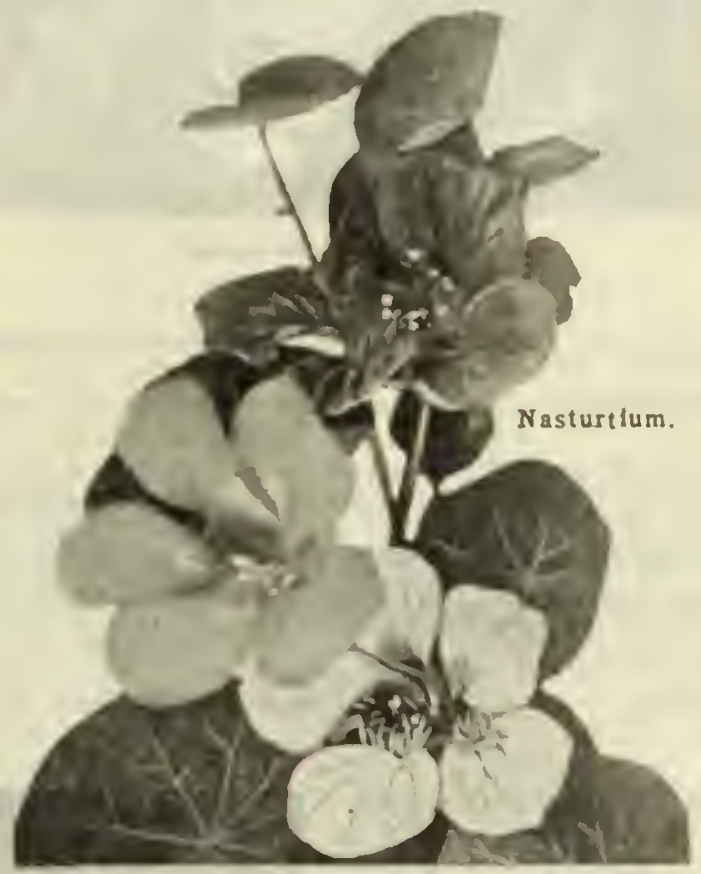

\section{NASTURTIUM}

Sow anywhere, except in the slacle. No ground is too poor to grow thein. Finc for cutting. The tall or trailing variety is a useful plant for trailing over walls or stumps. also for porch boxes or lianging baskets. The dwarf variety forms compact buslies. Both llower all summer.

Pine State Mixed. A grand nixture of all the best colors and everything good in tall nasturtiums. Pkt.

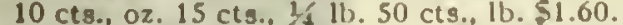

old North State Mixed. A very fancy mixture of all the best dwarf varietles. Pkt. 10 cls., oz. $15 \mathrm{cts.,} \mathrm{Ke}$ lb. $50 \mathrm{cts} ., \mathrm{lb} . \$ 1.60$. 


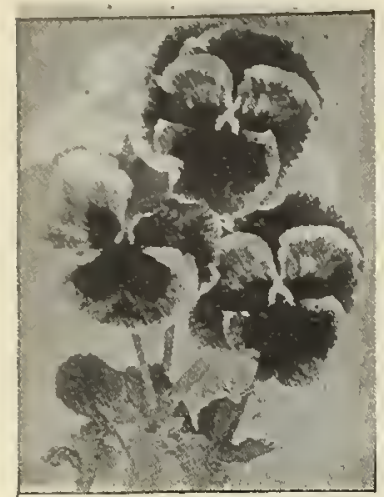

Pansies.

\section{PORTULACA}

Select the hottest, sunniest place for this little plant. Sometimes called "Rose Moss." Forms masses of delicate green foliage covered with bright colored flowers somewhat resembling small roses. Specially adapted for light, dry soils, and particularly for sowing on surface of beds of springblooming bulbs such as Tulips, Narcissus, etc.

Single Mixed. Pkt. 10 cts. $1 / 4$ oz. $40 \mathrm{cts}$.

Double Mixed. Fine. Pkt. 10 cts., $1 / 4$ oz. 65 cts.

\section{PANSY}

Can be sown in the spring or in September. Plants from the later sowings live over and flower in the spring. They require rich soil and quantities of water to do their best. Fancy Mixed. A very fancy strain, all colors. Pkt. 10 cts., $1 / 8$ oz. $\$ 1.00$, oz. $\$ 5.00$.

Large Flowering Mixed. Many standard varieties. Pkt. $10 \mathrm{cts}$., $1 / 4$ oz. $50 \mathrm{cts}$., oz. $\$ 2.00$.

Pansy Plants in season. 50 cts. per doz., postpaid; $\$ 3.75$ per 100 by express.

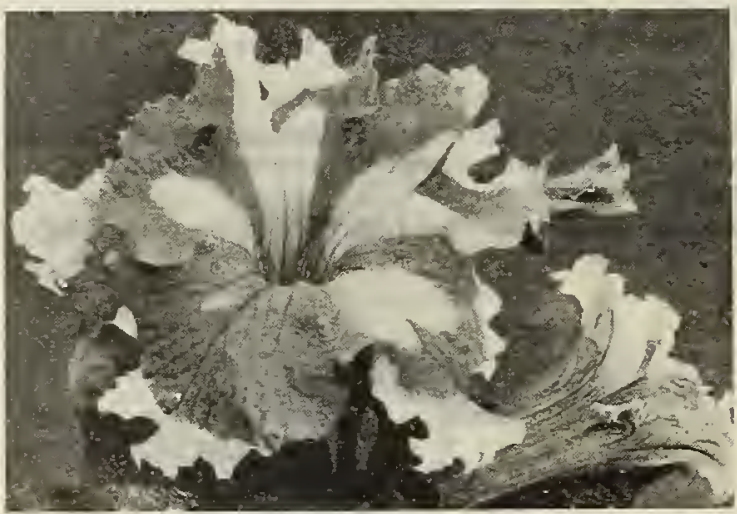

Ruffled Giant Petunias. PETUNIA

One of our finest bedding plants, blooming constantly from June until frost. Hardy annual.

Mixed colors. The regular type of Petunias in assorted colors, Pkt., $10 \mathrm{cts} ., 1 / 4 \mathrm{oz}$. $30 \mathrm{cts}$., oz. $\$ 1.00$.

Ruffled Giant. Very large-flowered; ruffled, fluted and fringed, striped and mottled, blotched and self-colors. Pkt. 15 cts., $1 / 4$ oz. 75 cts.

Rosy Morn Selected. Pkt. 15 cts., $1 / 4$ oz. 75 cts.

White Petunia. A selected strain for bedding. Pkt. $15 \mathrm{cts} ., 1 / 4 \mathrm{oz} .75 \mathrm{cts}$.

Deep Purple. Pkt. 15 cts.

Countess of Ellesmere. Rose with white throat. Pkt. 15 cts.

\section{PHLOX DRUMMONDII}

A hardy annual, with a greater range of colors than almost any other flower, and no other surpasses it in freedom of bloom. Transplant ing readily, and as the seed is rather slow in starting, it pays to start it in a hot bed or box in the house.

Large Flowering Mixed. Pkt. $10 \mathrm{cts.}, 1 / 4$ oz. $35 \mathrm{cts}$. oz. $\$ 1.00$.

Crimson. Pkt. 10 cts., 1/4 oz. 50 cts.

White. Pkt. $10 \mathrm{cts} ., 1 / 4 \mathrm{oz}$ $50 \mathrm{cts}$.

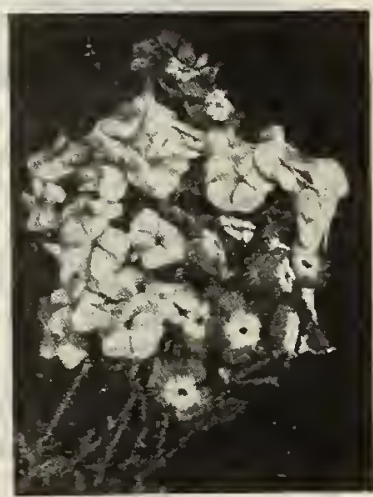

Phlox

\section{PERIWINKLE (Vinca)}

A free bloomer with glossy green leaves and bright rose and white flowers. As bedding plants for the garden they rival the Geranium. Their sof $t$ and delicate colors and profuse blooming habit makes them at all times attractive. $2 \mathrm{ft}$. Mixed colors. Pkt. $10 \mathrm{cts} ., 1 / 4 \mathrm{oz}, 40 \mathrm{cts}$. $1 \mathrm{oz} . \$ 1.25$.

\section{POPPIES}

Very hardy and can be sown as early in the spring as the ground is in working order, the annual varieties flowering from June on for some weeks.

Shirley Mixed. The very finest strain of single Poppies. all colors, from white to deep scarlet. Pkt. 10 cts., $1 / 2$ oz. 40 cts., oz. 75 cts.

Shirley Scarlet. Pkt. $10 \mathrm{cts}$. Shirley Rose. Pink. Pkt. 10 cts.

Peony-Flowered, Very double and fine. All colors. Pkt. 10 cts., $1 / 2$ oz. 25 cts., oz. 45 cts.

Oriental This is extremely hardy, and once extablished lasts for years. It produces immense single scarlet flowers 4 inches across in early summer, and makes a gorgeous display. Pkt. $10 \mathrm{cts}$., $1 / 8 \mathrm{oz} .25 \mathrm{cts}$.

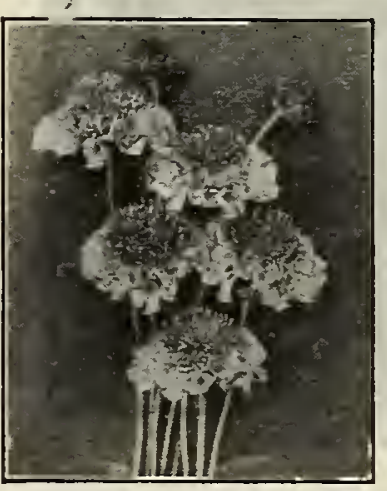

Scabiosa.

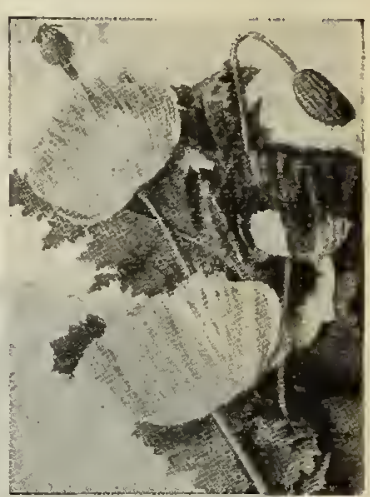

Shirley Poppies.

\section{RICINUS (Castor-Oil Bean)}

An annual plant, making a rank growth in one season, frequently to the height of 6 to 8 feet, with immense leaves. Fine for the center of foliage beds or as a screen.

Mixed Varieties. Many kinds. Pkt. $10 \mathrm{cts}$, oz. 15 cts

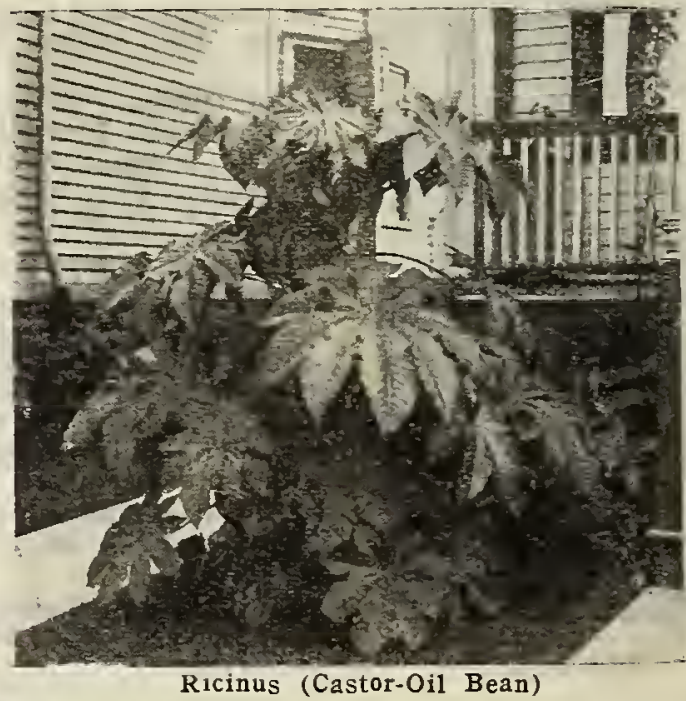

Inoculate Soy Beans and Cowpeas whether growing them alone or in mixture, inoculate with Farmogerm. 


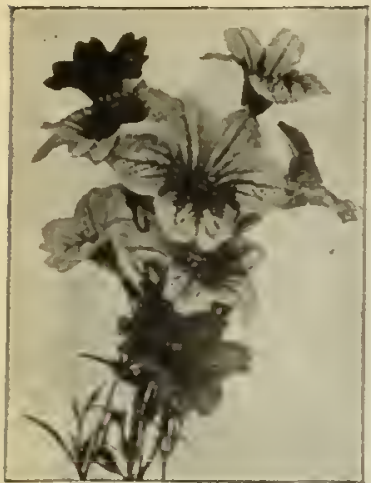

Salplglossis.

\section{SALPIGLOSSIS}

Emperor. A beautiful and easily grown annual, producing velvety-looking flowers in many colors, sonewhat in shape of Petunias. Halihardy annual. Pkt. $10 \mathrm{cts.,}$ $1 \% \mathrm{oz} .35 \mathrm{cts} ., 16 \mathrm{oz}, \$ 1.00$.

\section{SALVIA (Scarlet Sage)}

This ranks with the geraniums as a beddling plant and is easily raised from seed. Long sprays of brilliant scarlet flowers in late summer. Pkt. 10 cts., if $0 \% .60$ cts. $0 \% . \$ 2.00$.

\section{SCHIZANTHUS}

(Butterfly Flower)

Also known as "The Poor Man's Orchid." 1)ainty, compact. branching plants with finely cut foliage, covered when in bloom witl clusters of brilliantly colnred butterflylike flowers. One of our very finest annuals, deserving of a prominent place in every flower garden. Plant 15 to 20 inches ligh. Large flowering Hobrids. Mised. Pkt. $10 \mathrm{cts}$, Is Oz. $20 \mathrm{cts}$.

\section{CYPRESS VINE (Impomoea Quamoclit)}

One of the most popular vines, with very delicate fern. like foliage, and masses of beautiful, small, star-slaped flowers. Sow in April and May. first soaking the seerls im warm water for a few hours. Height 15 feet.

Mixed. White and scarlet. Pkt. $10 \mathrm{cts.0} \mathrm{If} \mathrm{oz.} 15 \mathrm{cts.}$ oz. $40 \mathrm{cts}$

Cardinal Climber. (Quamoclit IIybrida). The best annual climber introduced in many years; beautiful fernlike foliage and brilliant cardinal flowers. Pkt. $15 \mathrm{cts}$., 2 pkts. $25 \mathrm{cts}$.

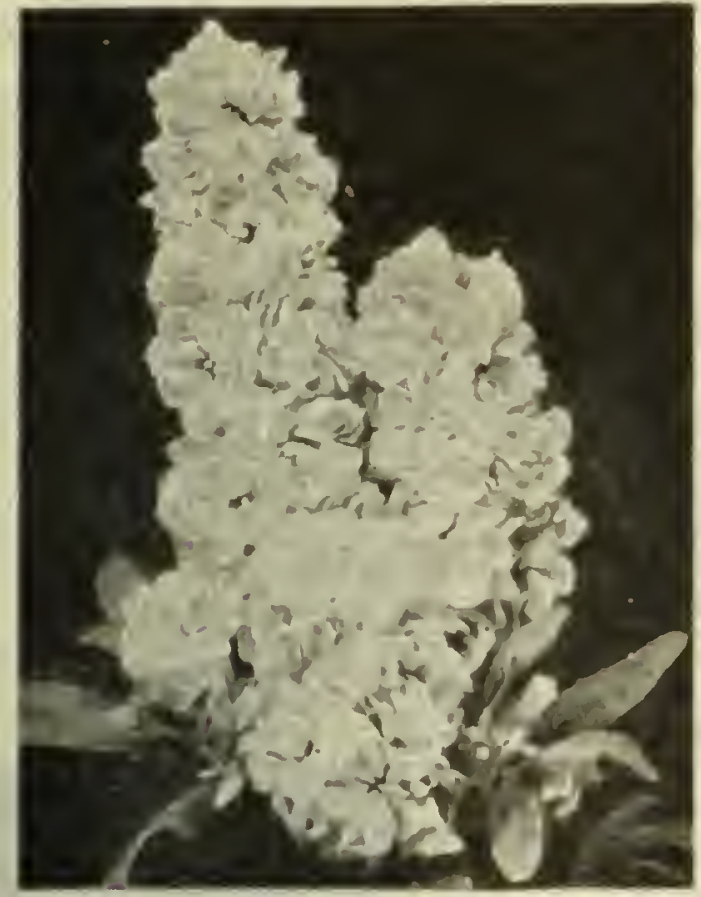

Ten Weeks Stock.

\section{STOCK, TEN WEEKS}

An annual userl largely for lerleling purposea, and grown in pots for spring flnwirs. 11.1 a long spikes of blom. White, pink amd crimsun; single and clouble very frigrant. Ilalf-liarly innual.

Dwart Mixed. I'kt. 10 ets., I, nz, 3.5 cta.

\section{HEDGES FROM SEED}

Marvel of Peru (Four o'Clock). Silvia (Filnwering Sage). Koclia (Summer Cypress or Burning 13usli).

\section{RUDBECKIA}

Bicolor Superba (Cone-flower). 2 feet. Produces an abundance of briglit yellow flowers with brown central disc; fine for cutting. Pkt. $10 \mathrm{cts}$.

MIXED CANNAS (N. C. Grown Roots) $75 \mathrm{cts}$. per doz., $\$ 5.50$ per 100 , postpaid.

HELIANTHUS (Hardy or Perennial Sunflower) Pkt. $10 \mathrm{cts}$. Strong plants, $25 \mathrm{cts}$. each, $\$ 2.50 \mathrm{doz}$. SUNFLOWER

Very hardy annual plants; grown everywhere.

Double California. Handsome, extremely double flow. ers. Pkt. $10 \mathrm{cts} . .0 \mathrm{z} .20 \mathrm{cts}$.

Chrysanthemum. Flowered. A fine varietv, double and of vigorous growth. Pkt. $10 \mathrm{cts.,} \mathrm{oz.} 20 \mathrm{cts}$.

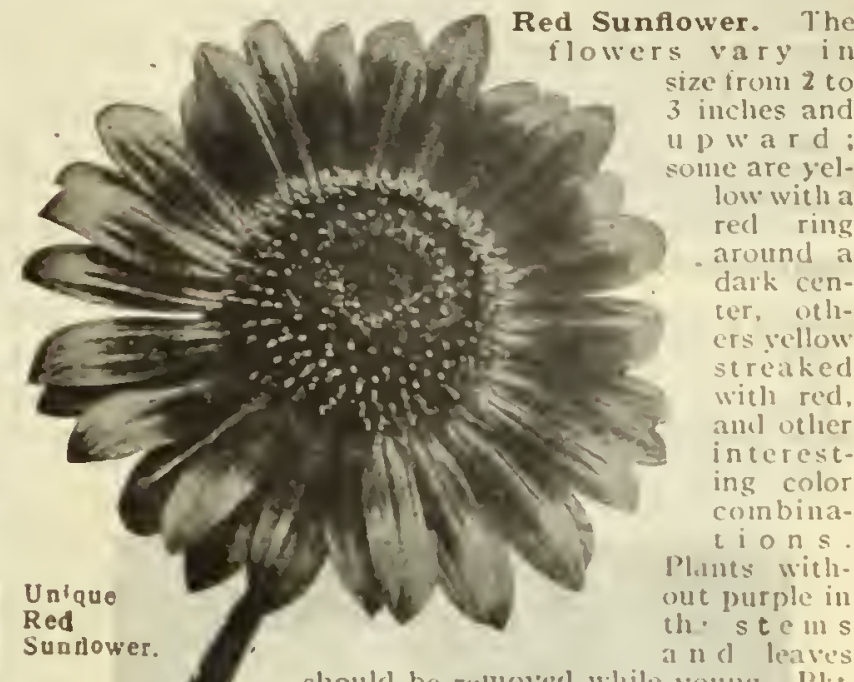

Sundower. should be remosed while al in leaves

$10 \mathrm{cts}, 1$ 1 $02.25 \mathrm{cts}, 0 ., 40 \mathrm{cts}$.

Miniature Sunflower Mixed. Sll the newest and best varieties, some a single colors, others black rentered, with golden yellow petals, others resembling cac. tusclahlias, nıan with curiously twisted petals. I'kt. $10 \mathrm{cts} . I_{y} 02.20 \mathrm{cts}$

Special Rates on Packet Flower Secds Select any Tlirec $10 \mathrm{c}$ size $10 \mathrm{r} \ldots \ldots \ldots \ldots .0 .25$ Select any Seven $10 \mathrm{c}$ size fur.

Slect any Fifteen $10 \mathrm{c}$ size for.

\section{- CHINESE WOOLFLOWER}

Large clubular heads like balls of wool or chessille, and of a bright red color. The plants grow 2 to 3 feect in lieight, branch freely, each branch terminating with" thower head. Pkt. $10 \mathrm{cts}$.

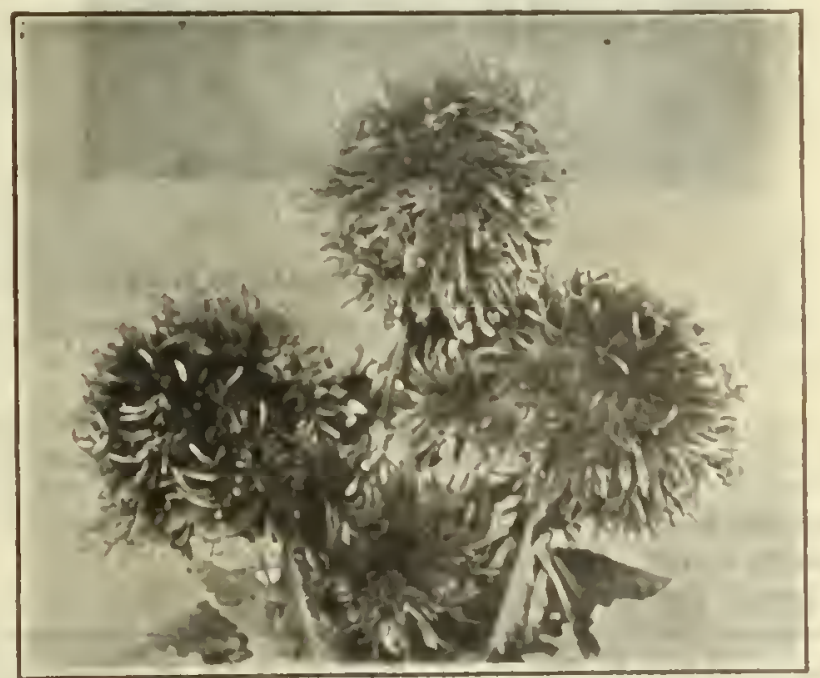

Chinese wootfower.

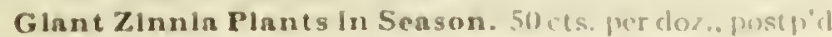

Seeds in Quantity. Market.Gardeners and Public Instltutlons who buy Vegetable Sceds in large quantitles stantlal reductlons on large orders. 


\section{WTATT'S GIANT DOUBLE ZINNIAS}

(See illustration, back cover).

A giant strain of this grand old favorite, free and continuous flowering annual, which produces flowers of colossal size, specimens measuring from 5 to 6 inches across being not unusual. Plants are of extremely robust habit. attaining a height of about three feet and bearing on long stems numerous semi-globular, mostly very double flowers, all of the largest size, making them of great value in large beds, borders, etc.

Giant Apricot Yellow. Pkt. $10 \mathrm{cts}, 1 / 4 \mathrm{oz} .40 \mathrm{cts}$. Giant Purple. Pkt. $10 \mathrm{cts.,} 1 / 4$ oz. $40 \mathrm{cts}$.

Giant Golden Yellow. Pkt. $10 \mathrm{cts.}, 1 / 4 \mathrm{oz} .40 \mathrm{cts}$.

Giant Scarlet. Pkt. $10 \mathrm{cts} ., 1 / 4 \mathrm{oz} .40 \mathrm{cts}$.

Giant White. Pkt. $10 \mathrm{cts}, 1 / 4 \mathrm{oz} .40 \mathrm{cts}$.

Giant Flesh Color. Pht. $10 \mathrm{cts} ., 1 / 4 \mathrm{oz} .40 \mathrm{cts}$.

Giant Sulphur-Yellow. Pkt. $10 \mathrm{cts}$., 1/4 oz. $40 \mathrm{cts}$.

Giant Crimson. Pkt. $10 \mathrm{cts} ., 1 / 4 \mathrm{oz} .40 \mathrm{cts}$.

Collection of a packet of each of any 8 colors for $60 \mathrm{cts}$.

Giant Canary Yellow

Giant Lavender

Giant Pink

Giant Salmon Rose

Giant Orange

Giant Burnt Orange

Prices of above: Pkt. $10 \mathrm{cts} ., 1 / 4 \mathrm{oz} .40 \mathrm{cts}$.

Giant Mixed. Pkt. 10 cts., 3 pkts. for 25 cts., $1 / 2$ oz. 50 cts.

Double Dahlia-Flowered. The latest development in Zinnias, bearing flowers of mammoth size and in form like a perfect decorative Dahlia. 3 feet. Pkt. 10 cts. 3 pkts. 25 cts., oz. $\$ 1.25$.

Dwarf Double Mixed Zinnias. Fine for bedsand borders free bloomers. Height about 12 inches. Pkt. $10 \mathrm{cts} ., 1 / 4$ oz. 30 cts., $1 / 2$ oz. 50 cts., oz. 90 cts.

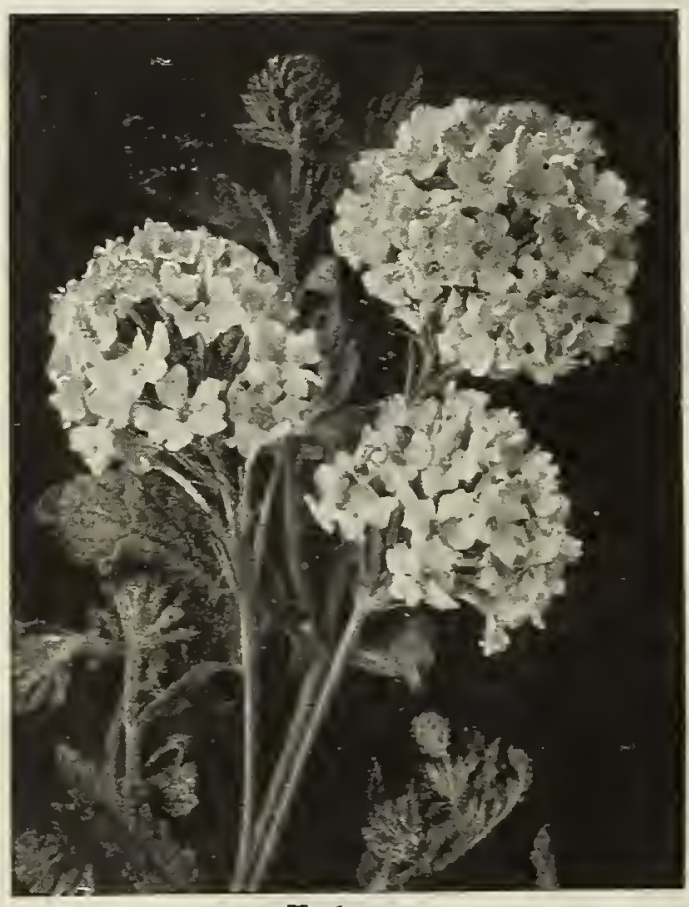

Verbena.

\section{WALLFLOWER}

Tender perennial; variegated. Has massive spikes of sweet scented flowers. 11/2 feet. Pkt. $10 \mathrm{cts}$.

\section{SWEET WILLIAM}

Old-time hardy perennial with dense heads of many colored flowers. For many: years Sweet William has been esteemed as one of our finest hardy garden plants, being of easy culture, thriving in any good garden soil and lasting for years.

Double Mixed. Pkt. $10 \mathrm{cts} .1 / 2 \mathrm{oz} .50 \mathrm{cts}$.

Single Mixed. Pkt. $10 \mathrm{cts} ., 1 / 2 \mathrm{oz} .50 \mathrm{cts}$.

Annual Variety. Mixed colors. Pkt. $10 \mathrm{cts} ., 1 / 2 \mathrm{oz} .30 \mathrm{cts}$.

Practical Landscape Gardening, by Robt. B. Cridland. Gives all needfulinstruction on every detail connected with landscape gardening and as to the embellishment of the home grounds. 91 photographic illustrations, 76 sketches and 33 plans, 276 pages: $\$ 2.65$, postpaid.

Make Your Garden a Wonder Garden. Use STIM-U-PLANT. See page 45.

\section{THUNBERGIA}

Beautiful, rapid growing annual climbers, preferring a vases, low fences, etc., very pretty flowers in buff, white, orange, etc., with dark eyes; mixed colors; 4 feet.

\section{VERBENA}

No more attractive low-growing or trailing plants can be had. The trusses and individual flowers are of large size of brilliant colors, free-blooming and of vigorous habit. For best and quickest results seed should be sown early in the house or hot bed, and transplanted to flowering quarters in May. Verbenas are better grown from ing cuttings, being more vigorous and not starts slowly. Hardy annual.

Mammoth. Very large flowers. Fine mixed. Pkt. 10 cts., $1 / 4$ oz. 30 cts., oz. $\$ 1.00$.

Fine Mixed. Pkt. $10 \mathrm{cts} .1 / 4 \mathrm{oz} .25 \mathrm{cts} ., 0 z .75 \mathrm{cts}$.

Wiant Pink. Plt. $10 \mathrm{cts}$.

Giant Blue. Pkt. $10 \mathrm{cts}$. Giant Purple. Pkt. $10 \mathrm{cts}$

Giant Scarlet. Pkt. $10 \mathrm{cts}$.

Italian Striped. Pkt. $10 \mathrm{cts}$.

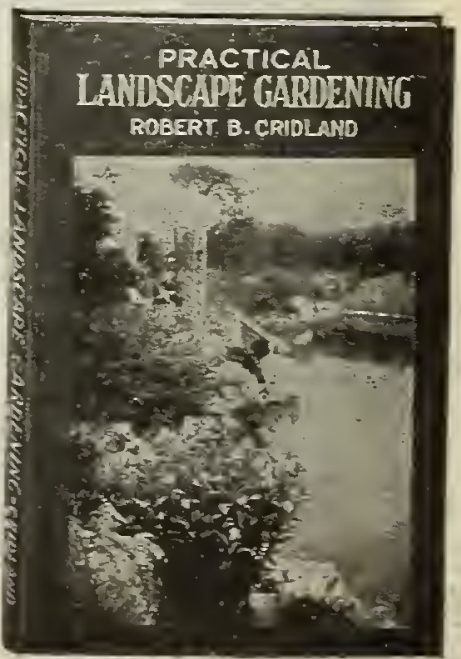




\section{OLD NORTH STATE SWEET PEAS}

These are almost hardy enough to Hive out overwinter, and they make their best growth in the cool part of the season. The only way to have them last at all, once the hot weather comes, is to have them deeply rooted by that time, so plant as soon as you can stir the ground in the spring, when it is not muddy. covering 2 inches. Frost will not hurt them. Cultivate thoroughly, plant about 1 inch apart in rich ground; give plenty of water as soon as plants are up. Can be sown in the fall, November being a good time.

\section{SPENCER OR STANDARD SWEET PEAS}

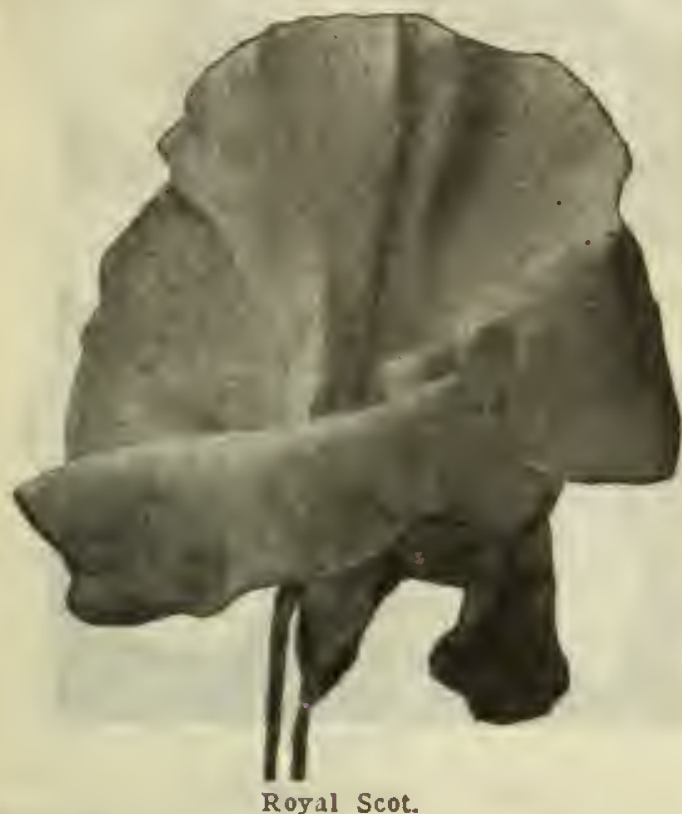

Primrose Spencer. Clear primrose sliade.

Dobble's Cream. Extra deep, selected stock.

\section{ROSE AND LIGHT PINK BICOLOR}

Pkt. 10 cts., oz. 35 cts., 1 lb. $\$ 4.00$.

Mrs. Culbertson. Giant; rose and light pink.

Blanche Ferry. Pink and white; the old popular and well-known sweet pea.

\section{RED SHADES}

Pkt. 10 cts., 0z. 35 cts., $1 / 4$ lb. $\$ 1.25$.

King Edward Spencer. Large blood-red.

Flery Cross. Bright red orange cerise.

ORANGE AND SALMON-PINK

Pkt. 10 ets., Oz. 35 cts., $1 / 4 \mathrm{lb}$ l $\$ 1.25$

Royal Scot. Beautiful orange.

Robert Sydenham. Bright orange salmon.

Mrs. Hugh DIckson. A bcatutiful salmon-pink on a cream ground, color effect rich apricot; extra fine.

The Presldent. Brilliant orange.

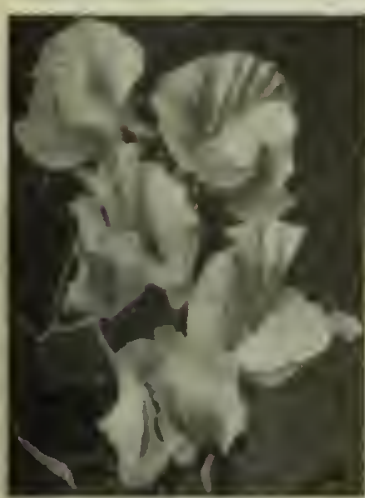

Countess Spencer
Hawlmark Cerise. Brlght salmon cerise.

MAROON, PURPLE, BLUE Pkt. $10 \mathrm{cts.,} \mathrm{oz.} 35 \mathrm{cts}$.

Othello. Deep velvety maroon. Best of the dark-colored Speneers; large size.

Lord Nelson, or Brilliant Bluc. Deep navy blue.

Crptain of the Blucs. One of the finest in our collection with purplisl matron standard and bluigh wings. True Spencer type.

Royal Purple. Rich purple. Wedgewood Speclal Strain Bluc.

Asta Ohn. Pinkiah lavender.

\section{LAVENDER SHADES}

Flora Norton. The finest pure lavender. A beauty. Florence Nightingalc. A large and fine pure lavender: a great favorite. Pkt. $10 \mathrm{cts} .0 \mathrm{z}, 35 \mathrm{cts}$

R. F. Felton. Exquislte, soft lavender blue with slight ouffusion of rose. Flowers of largest size. Pkt. $10 \mathrm{cts}$. oz. $35 \mathrm{cts} ., 1 / 3 \mathrm{lb} . \$ 1.25, \mathrm{lb} . \$ 4.00$.
WHITE

Pkt. 10 cts.. 0z. 35 (Tinton arge; white : it seeded. REAM-PIN K HADES

aret A le e.

35 ets.

PINK SHADES

$10 \mathrm{cts} .0 z .35$ ets. $1 \mathrm{lb}$

Countess Spencer. Clear pink. Pearson. Light pink. paler shadings.

plear pink; very large sh pink.

RIMROSE SHADES

10 ets., oz., 35 cts.

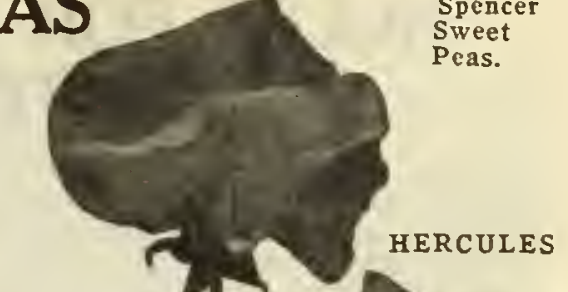

ERCULES

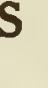

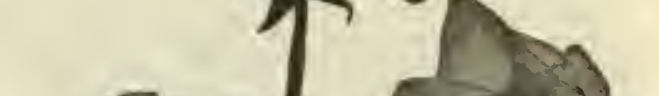

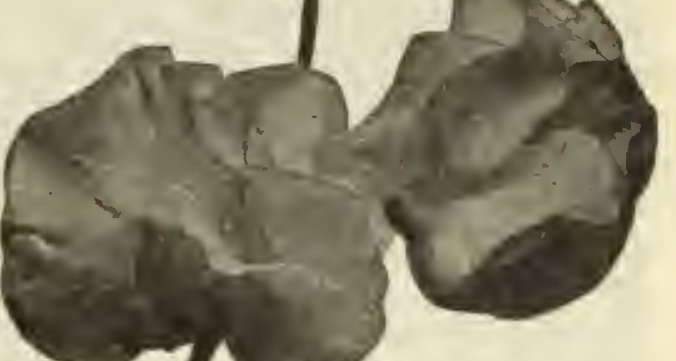

10 ets.

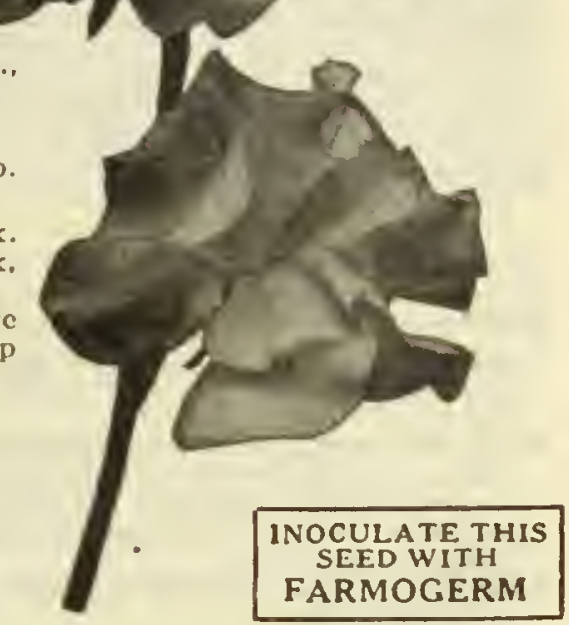

SEPARATE COLORS OF SPENCER SWEET PEAS

Price. All Varieties: Plet. $10 \mathrm{cts.,} \mathrm{oz} 35$ cts., 1/4 lb. $\$ 1.25$ Ib. $\$ 4.00$.

\section{SPENCER MIXED SWEET PEAS}

A very fine assortment of colors, including the best varieties. Pkt. $10 \mathrm{cts.,} 0 \mathrm{z} .25 \mathrm{ets.}$ 1/ $\mathrm{lb} .75 \mathrm{cts} .1 \mathrm{~b}$. \$2, ppd.

\section{WYATT'S SPECIAL MIXTURE}

A blend of the best Sweet Peas in eultivation. No dull colors, all choice giant-flowering varietics of every color and type. the colors being evenly distributed throughout. No other Sweet Pea mixture can surpass "Vyatt's Special Mixture." Pkt $10 \mathrm{cts.0}$ oz. 25 cts., $1 / 4 \mathrm{lb} .65 \mathrm{cts}$. Ib. \$1.75, postpald.

\section{FANCY GRANDIFLORA SWEET PEAS}

Pkt. 10 cts., oz. 20 cts., \& 1b. 50 cts., 1b. \$1.50.

Dorothy Eckford. A grand white; the stems extra long and stiff; the best white of this type.

King Edward VII. Crimson-scarlet. A fine, extra-large flower; nearly always borne three on a stem.

Lady Grisel Hamuton. The largest and lightest of lavender, standard liglit mauve; liooded form.

Mrs. Routzahn. Color buft, suffused with delicate pink, whieh deepens to a rose near edge of wings and otandard

Prima Donna. Lovely soft pink, hooded form; vigorous grower.

OI.D NORTH STATE SWEET PEA COLLECTIONANY SEVEN IO-CENT PACKETS FOR 50 CENTS POSTPAID.

The Book of the Swoot Por, By D, B. Crane. Price $\$ 1.75$.

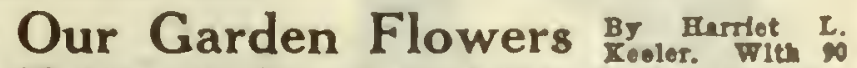
sull-page lllustratlons from photographs and 186 lilustratton. from dravinge. A popular studs of thols mative inds. thelr lifo blstortes, and thoir structural aclliation. p.50. 


\section{BULBS FOR SPRING PLANTING}

\section{CANNAS}

The gorgeous flowers and splendid foliage of the Canna are gaining for it greater popularity each season. No lawn or park seems complete without its tropical leaves and its mammoth flower-spikes that are a mass of bloom from July until frost.

Although astonishing success with Cannas will often be had under most unpromising conditions, they respond so luxuriantly to care that it is well worth while to take a little trouble at the start. The bed should be spaded to a depth of at least a foot and an abundance of well-decomposed manure worked in, and the toots set 4 or 5 inches under the surface. The "blazing" effects for which Cannas are so famous are best secured by the use in for which Cannas are so famous are best secured by the use in
masses, with the roots set not more than 2 feet apart-dwarf masses, with the roots set not more than 2 feet apart-dwarf
kinds being set even more closely. All Cannas love water, and in dry seasons blooming will be much more profuse and constant if the soil be kept always moist. In the South, planting may be done as early as the last of March, but if early bloom is wanted the best way is to start them in pots under protection, trans. planting to the open ground when danger of frost has passed.

The President. $4 \mathrm{ft}$. In color a rich glowing scarlet and the immense rounded flowers, seven inches across when fully open are produced on strong erect stalks well above the large green foliage. Free bloomer and strong grower. Each $15 \mathrm{cts}$. dozen $\$ 1.50,50$ for $\$ 5.50,100$ for $\$ 10.00$.

Austria. $4 \frac{1}{2}$ feet. Pure canary yellow with crimson spots in the center of the two inside petals. Each $15 \mathrm{cts} ., 2$ for $25 \mathrm{cts}$. $\$ 1.25 \mathrm{doz}$

City of Portland. $4 \mathrm{ft}$. The most beautiful pink; a fine bedder and profuse bloomer.

Eureka. $4 \mathrm{ft}$. The finest white or cream-colored Canna,

Gladiator. $41 / 2 \mathrm{ft}$. A leader for years. Color is bright yellow spotted with red. No other Canna in this color can surpass this sturdy robust grower.

King Humbert. $5 \mathrm{ft}$. The most popular Canna. Great orange-scarlet flowers surmount the vigorous dark bronze foliage throughout the season.

Louisiana. $6 \mathrm{ft}$. Vivid-scarlet; often 6 inches across; orchid flowered.

Panama. $31 / 2 \mathrm{ft}$. Orange-red with well-defined edging of bright yellow.

Richard Wallace. $4 \mathrm{ft}$. Canary-yellow flowers. Very floriferous. One of the best yellows.

Shenandoah. $4 \mathrm{ft}$. Flowers salmon-pink borne in large clusters, foliage rich ruby-red.

Yellow King Humbert. $4 \mathrm{ft}$. Rich yellow, spotted with bright red; often 5 to 7 inches across.

All varieties, except where noted, $15 \mathrm{cts}$. each, 5 for 50 cts., doz. $\$ 1.00$, postpaid, $\$ 6.00$ per 100 .

\section{SPECIAL}

$1 \mathrm{doz}$. Cannas, our selection, $75 \mathrm{c}$., prepaid, 100 jor $\$ 6.00$.

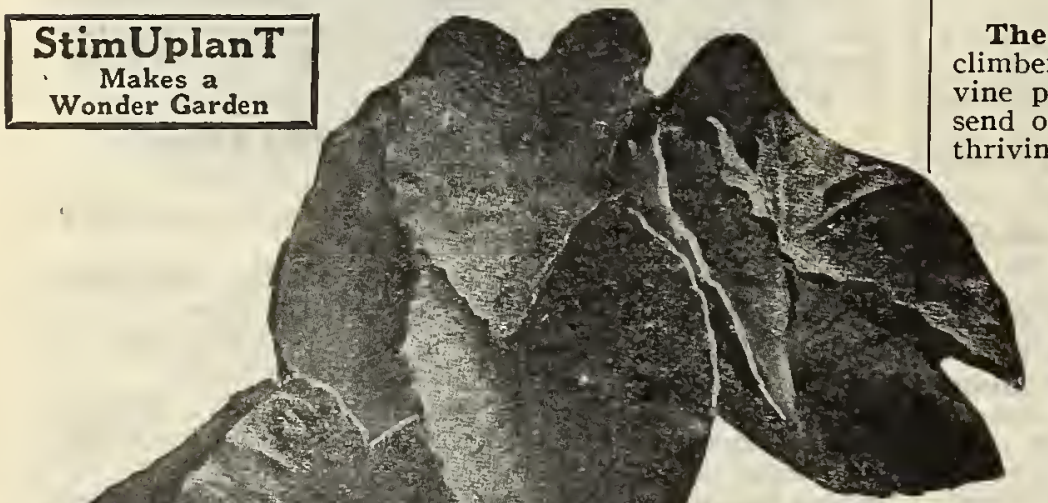

well drined in rich,

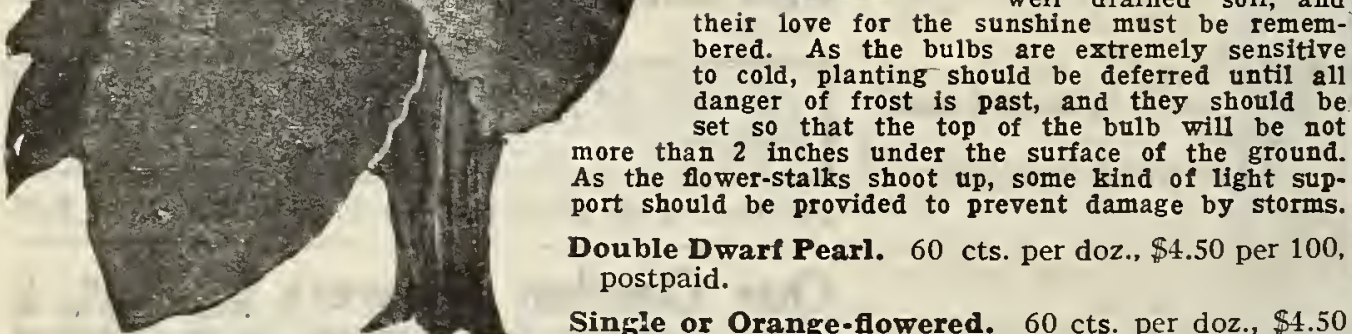

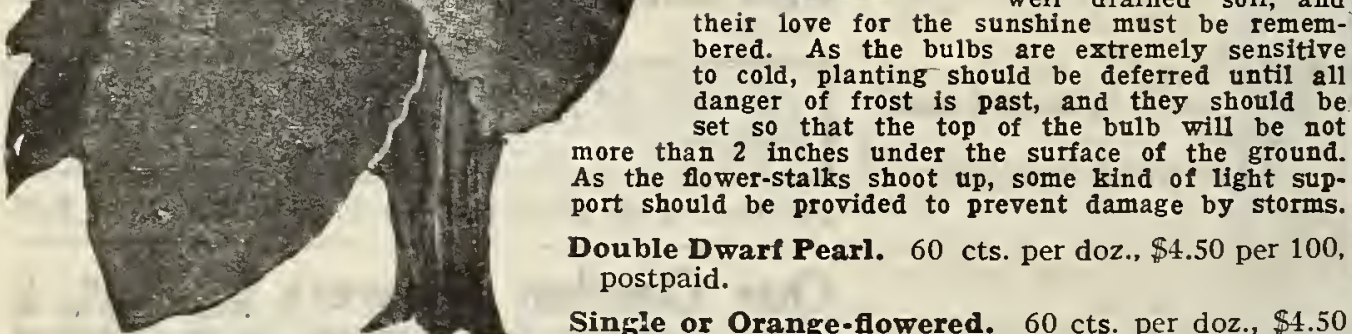

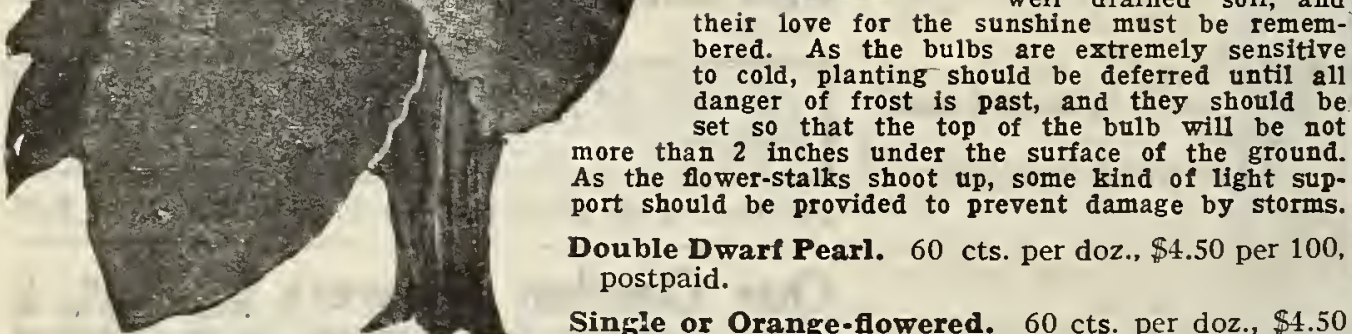

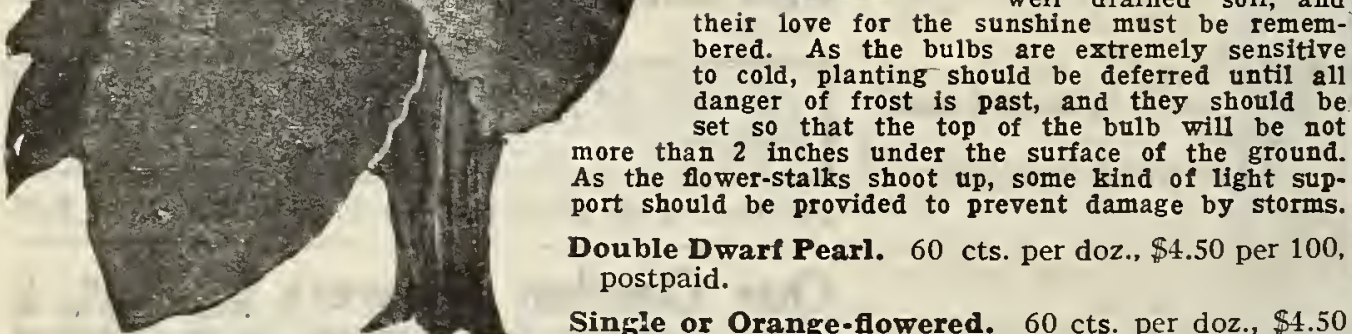

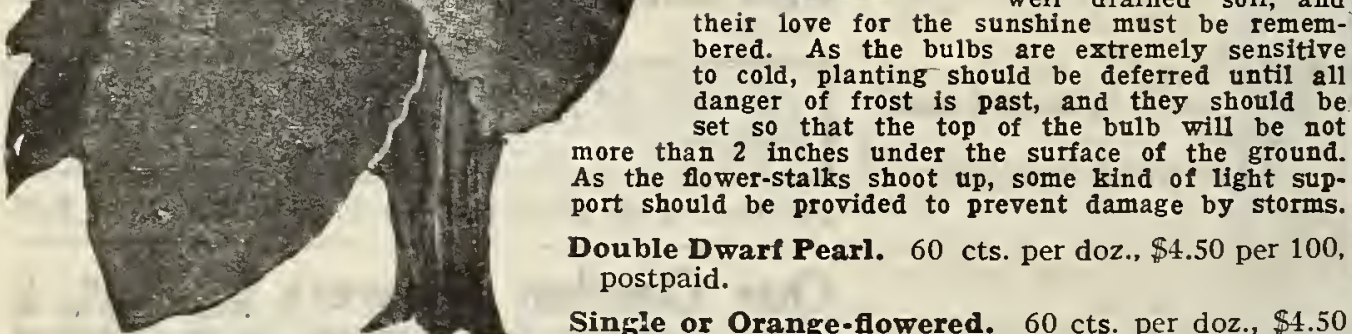

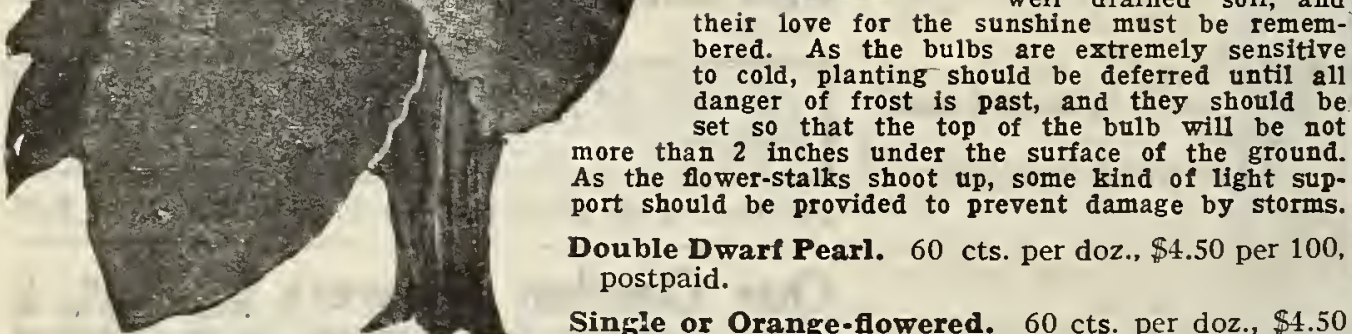

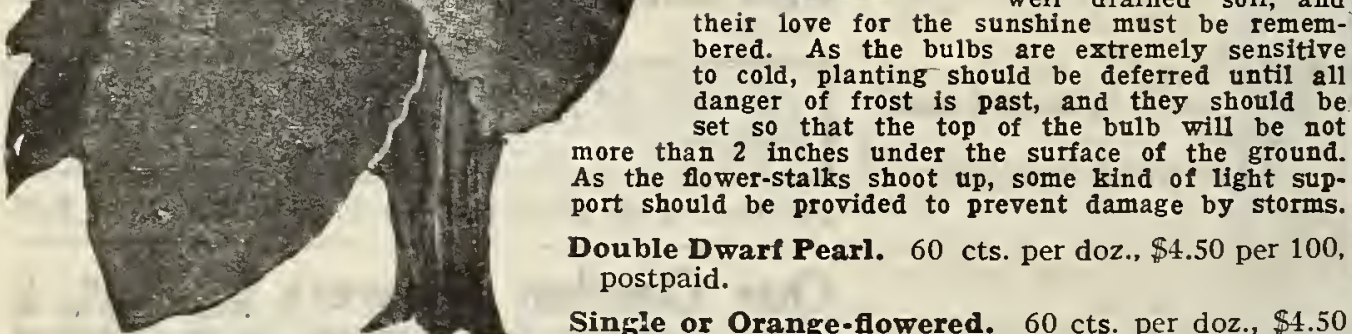

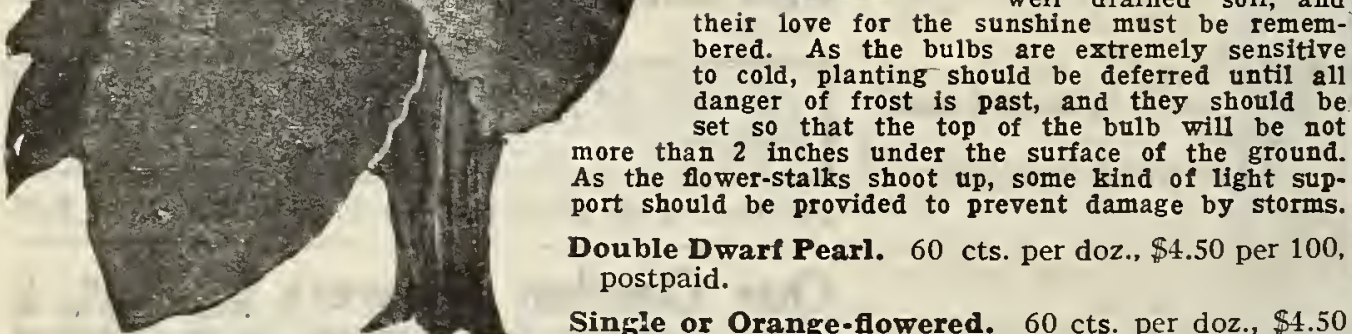

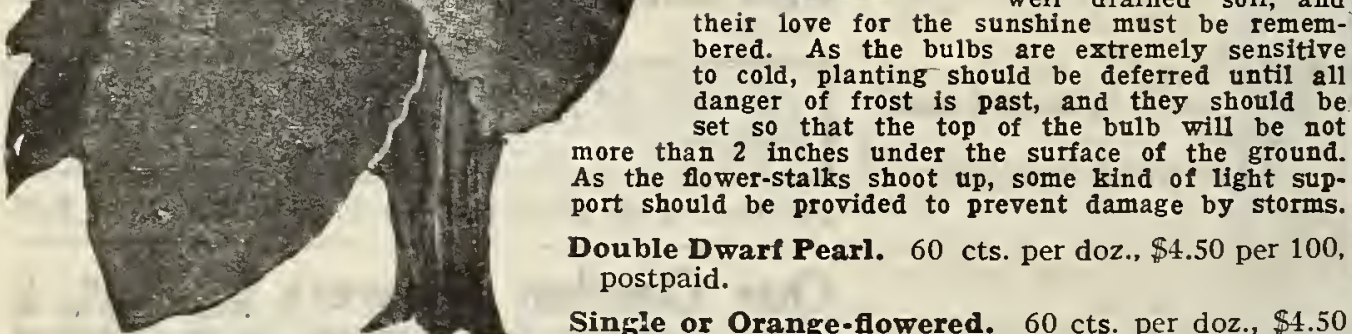

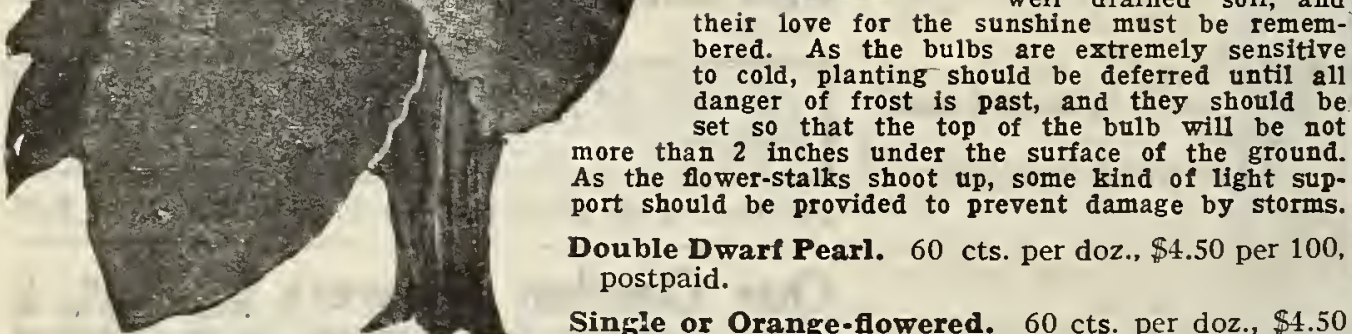

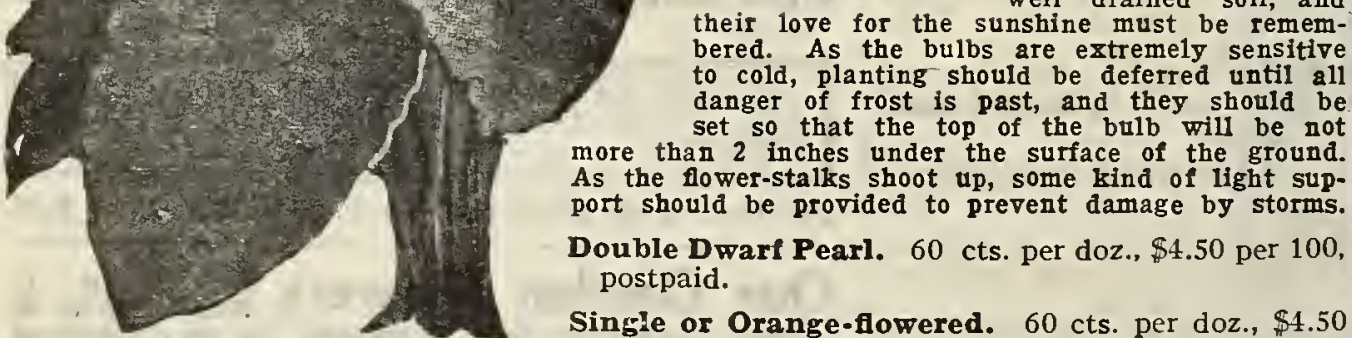

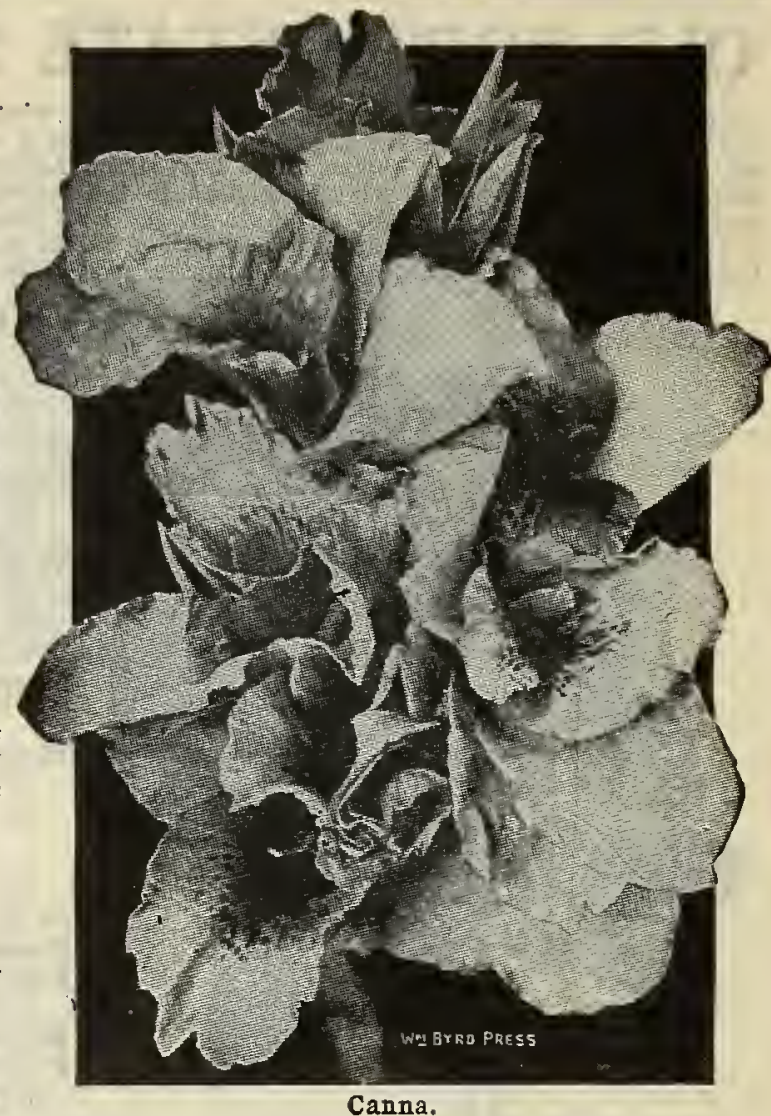

Canna.

(Elephant's Far). A very effective plant for setting out on the lawn either singly or in beds and massed in comany garden soil, but if given lots of moisture and rich high. Bulbs are safely stored over winter in dry sand.

Select Size Bulbs. Seven to nine inches in circum-

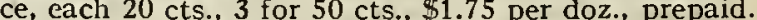

ach $30 \mathrm{cts} ., 3$ for $50 \mathrm{cts}$., dozen $\$ 3.00$, prepaid.

Mammoth Size. Eleven to thirteen inches in circumEach 45 cts. 3 for $\$ 1.00, \$ 3.90$ per doz., prepaid. greenhouse, conservatory, window-boxes, or for planting outdoors in a sheltered and shaded location. The eaves show a remarkable range of colors in beautiful variegation. $45 \mathrm{cts}$. each, 3 for $\$ 1.10,6$ for $\$ 2.15,12$ for CINNAMON VINE

The Cinnamon Vine is one of the most beautiful and will grow 30 feet in a single season. The clusters of delicate white flowers, which were it is wet or dry. Die down each winter, but up very early in the season. Good strong

TUBEROSES

This well known flowis highly prized for its delicate fragrance.

Tuberoses should Caladium Esculentum. per 100, postpaid.

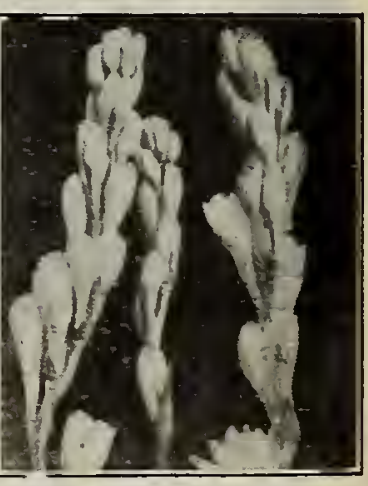

Tuberoses.
Double Dwarf Pear1 


\section{CACTUS DAHLIAS}

The Cactus Dahlias have large, loosely-formed. Chrysanthemumlike flowers. The long, narrow petals are variously rolled or twisted. Countess of Lonsdale. Rich salmon, tinted apricot. One of the easiest of all Cactus Dahlias. Each 35 cts.. doz. $\$ 3.50$.

Earl of Pembroke. Bright plum color; large, bold flowers. $25 \mathrm{cts}$. each.

Ella Kramer. Rose-pink with much brighter center; fine form. 25 cts. each.

Libelle. Clear, deep rose-purple, $25 \mathrm{cts}$. each.

Prince of the Yellows. Bright primrose-yellow. The flowers are large: petals long and pointed. $25 \mathrm{cts}$. each.

Standard Bearer. Brightest fiery scarlet, base tinged yellow. An immense flower. $25 \mathrm{cts}$. each.

Winsome. Pure cream white. 25 cts. each, $\$ 2.00$ per 10.

Kalir. This variet yoes exceptionally well in Raleigh. A truly. majestic flower. frequently measuring over 9 inches in dianeter, of perfect Cactus form, in color a pure scarlet. $60 \mathrm{cts}$. eacli, $\$ 5.00$ per 10 .

\section{DECORATIVE DAHLIAS}

Decorative Dahlias are intermediate between Cactus and Show The massive flowers are not so globular as those of the Sliow, and the petals are broad and somewliat flattened.

Dolly or Sylvia. White, edged pink, lery attractive. A great favorite with florists. $25 \mathrm{cts}$. each, doz. $\$ 2.50$.

Jack Rose. Rich glowing crimson, like the favorite old Rose, General Jacqueminot. Blooms early and profusely. The standard red Dahlia. $25 \mathrm{cts}$. each, doz. $\$ 2.50$.

Mina Burgle. Color, brilliant ruby red. $35 \mathrm{cts}$. each, doz. $\$ 3,50$.

Souvenir de Gustav Doazon. A pleasing shade of orange rell. Flowers are very full and often measure 9 to 12 inches in dianeter. $35 \mathrm{cts}$. each, doz. $\$ 3.50$.

Golden West. Very large pure yellow, good long stems for cutting. ends of petals split. $50 \mathrm{cts}$. each: doz. $\$ 5.00$.

Delice. Large fower with long stems, very fine for cutting, color clme hright rnsm-pink. 3.ets. caclı; doz. $\$ 3.50$.

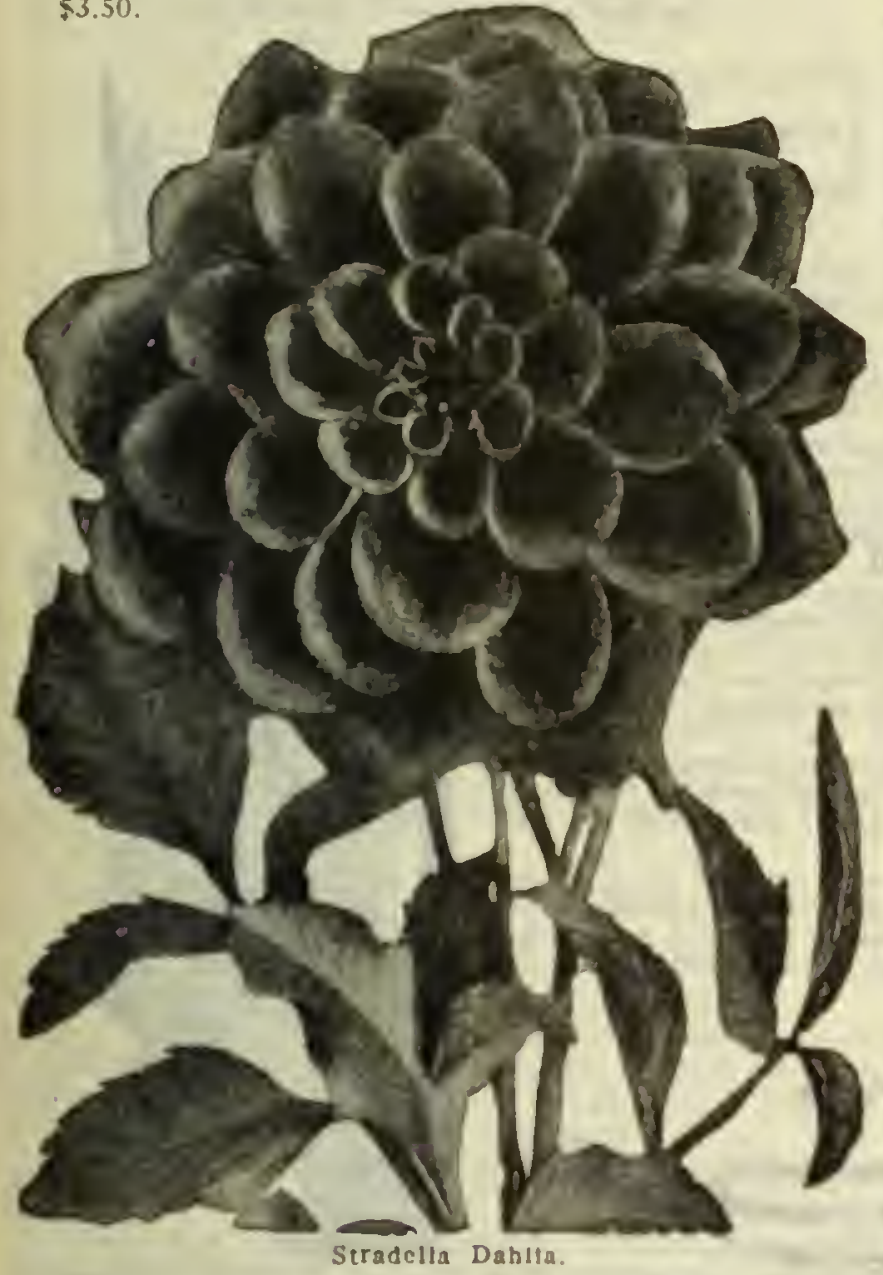

Minnie McCullough. Rich soft callary

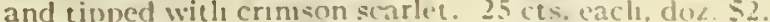

Lyndhurst. The best long stemmed, medium sized bright scarlet for cut flowers. $25 \mathrm{cts}$, each; doz. $\$ 2.50$.

Emuly. A fine variety for cut nowers, color white edged with lively rosy-lavender. $35 \mathrm{cts}$. each: doz. $\$ 3.50$.

\section{MIXED DAHLIAS}

A splendid mixture of many fine varieties. $15 \mathrm{cts}$. each 2 for $25 \mathrm{cts..} 12$ for $\$ 1.25$

\section{PEONY FLOWERED DAHLIAS}

Flowers are seni-tlouble, laving broad. Rat, lousely arranged petals.

Mrs. Jacques Futrelle. An expusite lemon-yollow heavily splasheol searlet. $25 \mathrm{cts}$.

Caechlla. A wonderfully harge creany-uhite hlower. 35 cts. each.

Mrs. M. W. Crowell. Color, a heantiful orange-yellou lery-free-fluwering. 25 its. ath.

\section{SHOW DAHLIAS}

The old-fashioned double Dahlia. Ball-glıped flowers the petals quilled or tubular. As a class they are more formal than the Cactus or Decorative.

Arabella. l,isht sulphur-yollow, shaded peach hosson at eeleres. $25 \mathrm{cts}$ each, dioz. $\$ 2.50$.

James Vick. Rich purple-crimaon. One of the best. 25 cts. each: doz. $\$ 2.40$.

Stradella. Deep wine-rnse, Very free-flowering. Long stems. $25 \mathrm{cts}$. each; doz. $\$ 2.50$.

vivian. A new favorite with wonderful fluwers of while edped rose-violet. Each 25 cts.. efor. $\$ 2.50$.

White Swan. P'ure whitr. A great favnite. Tlie hest bloomet In this class. 30 its. cach, doy. 5.300 .

A. D. Livonl. A beautiful soft bink. 25 ets. weth, $\$ 2.50$.

Yellow Duke. Very large canary yellow on long. stif stems; tixlitly quilled petals, 25 cts. each; doz. $\$ 2.50$.

\section{SPECIAL}

Select any 10 varieties listed at $25 \mathrm{cts}$. each for $\$ 2.00$ 


\section{GLADIOLI}

Gladioll are so inexpensive, so easily grown, and so beautiful both in the garden and as cut-flowers, that it is difficult to understand the general lack of interest in them.

Any good soll is suitable, and unlike most flowering bulbs in this climate, they not only do not deterioate, but on the other hand, increase rapidly. Planting may be done at any time in March, April, May, or June, the bulbs being set about 3 inches under the surface. As supports will be needed for the flowers, it is a good plan to put a dozen or more in a group around one stake, tying the stalks loosely to it. In the South the bulbs are best left in the ground and covered the South the bulbs are best

If wanted by mail, add $10 \mathrm{c}$ per dozen extra for postage.

America. Very popular. Flowers soft lavender-pink. Wellknown florist's variety. 7 cts. each, 75 cts. per doz., $\$ 5.00$ per 100 .

Chicago White. A good white Gladiolus. Flowers of great substance and an unusually good keeper. We recommend this highly. 7 cts. each, 75 cts. per doz., $\$ 5.00$ per 100 .

Marshal Foch. Beautiful soft rose-color; extra-large flower. A splendid novelty. 20 cts. each, $\$ 2.00$ per doz.

Baron Joseph Hulot (Blue King). The best blue Gladiolus. Rich indigo-blue. Do not fail to plant this. $10 \mathrm{cts}$. each, $\$ 1.00$ per doz.. $\$ 7.00$ per 100 .

Halley. Delicate salmon; blooms early. This is a beautiful variety. 6 cts. each, 65 cts. per doz., $\$ 5.00$ per 100 .

Mrs. Francis King. Well-known variety. Flame-color. One of the best for florists. 7 cts. each, 75 cts. per doz.,

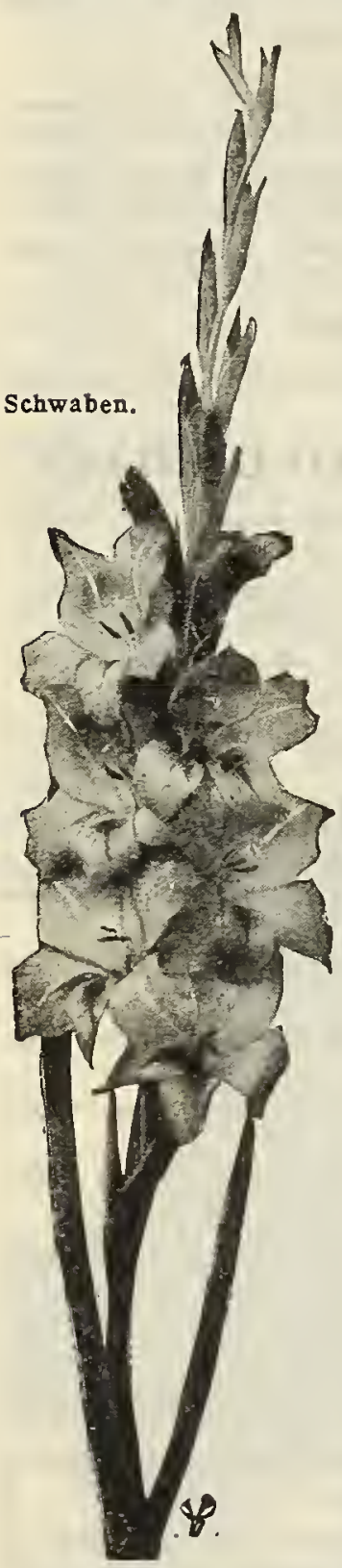
$\$ 5.00$ per 100 .

Mrs. Frank Pendleton. Rosepink, shading deeper to center of petals. $10 \mathrm{cts}$. each, $\$ 1.00$ per doz. $\$ 7.00$ per 100 .

Mrs. Watt. Deep wine-color. One of the most beautiful varieties we know. $10 \mathrm{cts}$. each, $\$ 1.00$ per doz., $\$ 7.00$ per 100 .

Niagara. Extra-fine light yellow. Flowers very large on strong stems. $10 \mathrm{cts}$. each. $\$ 1.00$ per doz., $\$ 7.50$ per 100 .

Panama. Color deep pink; wellexpanded flowers. $9 \mathrm{cts}$. each, 85 cts. per doz., $\$ 6.00$ per 100 .

Peace. This is a beautiful variety with fine, large, white flowers, with pale cattleya-like feathering on petals. 10 cts. each, $\$ 1.00$ per doz., $\$ 7.00$ per 100 .

War. Large deep blood-red, late. 12 cts. each, $\$ 1.15$ per doz.

Empress of India. Rich deep purplish-red. 12 cts. each, $\$ 1.25$ per doz.

Prince of Wales. Warm light salmon. An early variety and one of the most beautiful of these shades. $15 \mathrm{cts}$. each, $\$ 1.50$ per doz.

Princepine. Bright red with pure white blotches on lower petals. $10 \mathrm{cts}$. each, $\$ 1.00$ per doz., $\$ 7.00$ per 100 .

Schwaben. Primrose yellow, with dark blotches of brownish red in throat. 10 cts. each, $\$ 1.00$ per doz., $\$ 7.00$ per 100 .

Wyatt's Special Mixed Gladioli. This mixture is made up of fine selected stock from named varieties, and we can highly recommend same to our customers who require Gladioli in all colors. 60 cts. per doz., $\$ 4.50$ per 100 .

Common Mixture. Made up from a good assortment of varieties especially adapted for massing etc. 50 cts. per doz., $\$ 3.50$ per 100 .

Primulinus Hybrids. The upper petal droops, forming a "hood." The colors range from primrose yellow to a beautiful rose. 7 cts. each, 75 cts. per doz., $\$ 5.00$ per 100 , $\$ 35.00$ per 1,000 .

Ruffled Glory. Salmon-pink, with crimson stripe in the center of each lower petal. The broadly expanded, wide open flowers are carried on straight, stout $3 \frac{1}{2}$ foot stalks. Each petal is exquisitely ruffled. Each, $10 \mathrm{cts} .$, doz. $\$ 1.00$, $\$ 7.00$ per 100 .

\section{Spading Forks}

Three-Tine. Convenient, strong and well made: tines polished; hardwood handle; length, 11 ins. By mail postpaid 45 cts
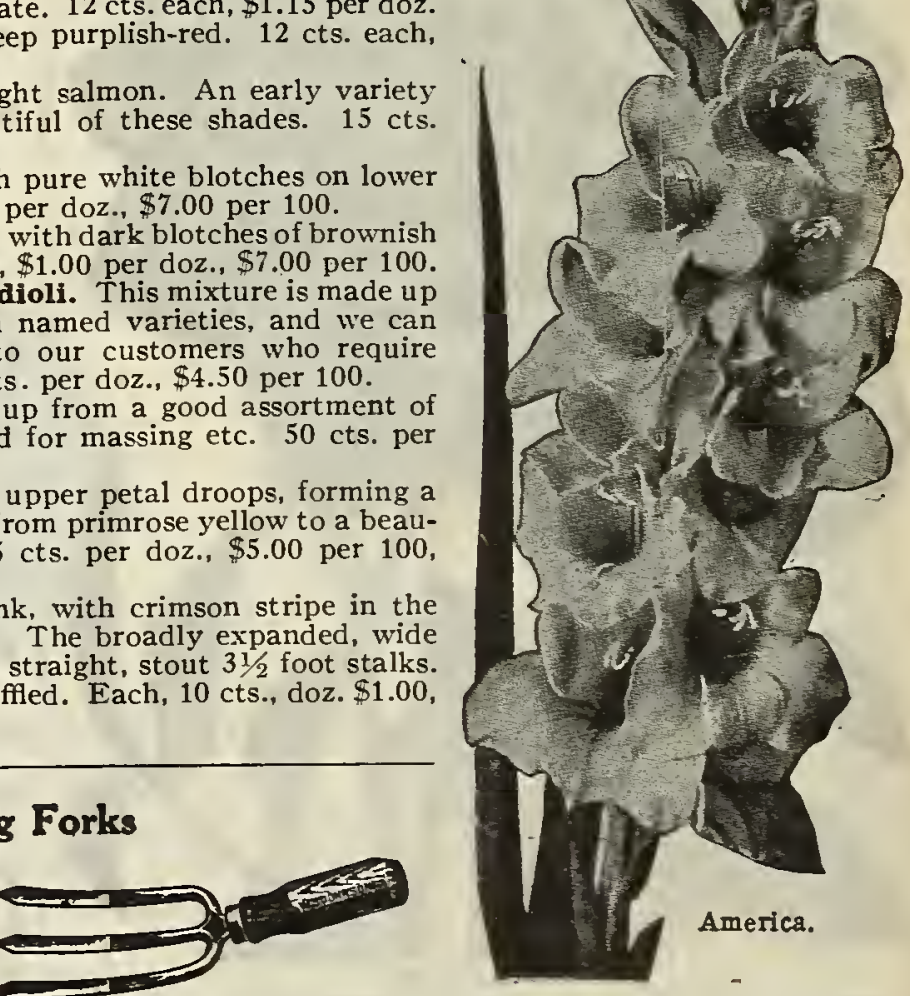

OUR BUTB CATAIOGUE which we sent out in September, contained all the various bulbs, and, of course, many varle ties can still be planted. If you do not have the list, we will send you one on receipt of postcard, 


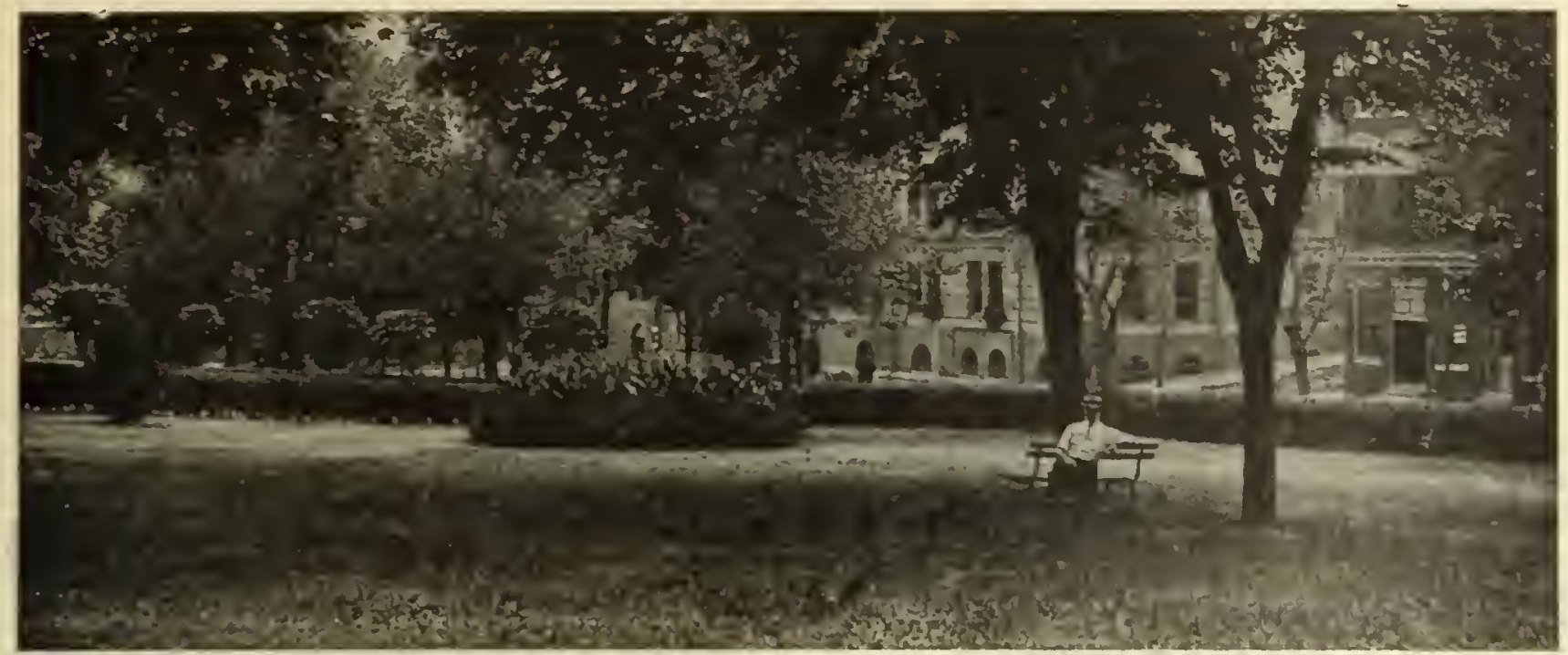

\section{WYATT'SIEVERGREEN MIXED LAWN GRASS}

In the South we often have trouble in getting good lawns because it has been found that no one grass will give satis. factory results at all seasons and on all soils. By careful experiments we liave succeded in getting a cotnbination of grasses that will produce an evergreen lawn. giving permanency and beauty of sward. By the use of this Evergreen Mixed Lawn Grass Seed a rich. velvety lawn can be nade and maintaimed. One pound will sow a space 10 by 25 feet or 250 square feet: 75 to 90 pounds to an acre. Lb. $50 \mathrm{cts} ., 5$ lbs. at $45 \mathrm{cts.,} 10$ lbs. and over $40 \mathrm{cts}$. per 11 .. 25 to 50 lbs. at $38 \mathrm{cts}$. per lb., 100 lbs. at $\$ 35.00$. By mail, postpaid. lb. $50 \mathrm{cts}$.

\section{Suggestions for the Making and Care of Lawns}

It must not be supposed that by sowing grass seeds at any scason of the year in soil of any cliaracter, and in any state of cultivation or neglect, a durable, attractive turf is to be formed. From the beginning the lawn is both troublesome and expensive, and even when obtained. it is like liberty, preserved only by "eternal vigilance." The coarser natural grasses and weeds will take possession unless kept down, and wherever. from any cause, a bare spot is formed it will rapidly enlarge unless repairecl.

As in housebuilding. so in the making of a lawn-a good foundation must be secured. or the rest of the work will be entirely wasted, and too great care rannot be exercised, since the roots unust be able to penetrate quite 18 inches in order to keep the grasses growing througli the scorching day's of July. August and September. If the ground is not already very rich, give a liberal application of fertilizer, avoiding the use of stable manure, as it invariably contains seeds of weeds anrl noxious grasses. Bone meal never produces tlie "burnerl" appearance so often noticed after the use of ammoniated fertilizers. Harrow or rake the surface to the finest possible condition and roll until all clevations and depressions liave been re moved.

Rake the seeds in liglitly, following with a roller of medium weight, a firmly rolled surface being absolutely necessary if the eround be dry; sinall areas may readily be packed firm by the back of a spade. Sowings made in the fall. from the first of Septemher to the iniddle of Decein ber, are most successful. but if deferred until sprink. sowings may be made in February, March, April and May.

When the grass is well set, about 4 incles ligh. it sliould be cut with a sickle or inown with the inachine set to avoid cutting too closely, 2 inches at least being left above the root. fifter that a cutting every ten dass and an occasional rolling will make tle grass fuer. sirengtlen the truf and keep all rank-growing weerls in clieck. In the heat of summer the mower should be arrauged so as to leave anple protection to the roots. [inless the drainage is perfect, it is mucl more injurious to give ton $\mathrm{mucl}$ water than to neglect watering altogether, and an occasional saturation is much better than the claily sprinkling commonly thought beneficial. If bare spots appear they unst be patched by breaking the grouncl alout 10 inclies deep. smoothing the surface and raking in clouble the usual allowance of seed. To maintain the vixor and color of the grass a light top dressing of lone meal two or three times a year is advisable. liberal applications of shecp. poultry and cattle manure are very beneficial and will give your lawn tlant ricl, velvety appearaner that is so inuch armirel loy everyone.

\section{Fertilizers}

SHEEP MANURE (Pulverized). A pure natural manure, uncemalled for mixing with potting soil for lawns reneral vegetable and flower carclens or for making liquid manure where quick as well as lasting results are wanted.

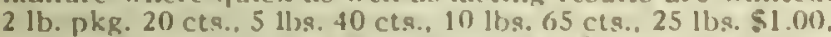
50 lhs. $\$ 1.75,100$ lbs. $\$ 3.25 .500$ lhs. $\$ 15.00,1.000$ llos. $\$ 26.00$, ton $\$ 50.00$.

CATTLE MANURE. Same price as Slicep Manure.

\section{PREMIER BRAND PULVERIZED POULTRY MANURE}

10 lbs. 7.5 cts., 50 lbs. $\$ 1.75,100$ lhs. $\$ 3.25$

NITRATE OF SODA. Fifteen per cent nitrogen, equiv. alent to over 18 per cent aminonia. Lb. 15 cts.. 5 lbs. 50 cts., 10 lbs. 80 cts., 25 lbs. $\$ 1.75 .50$ lbs. $\$ 1.50$.

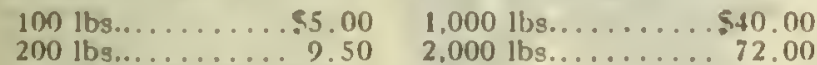

"Don't take a chance on fallure. If you inoculate with FARMOGERM you sTe sure of success. (Sce page 18)."

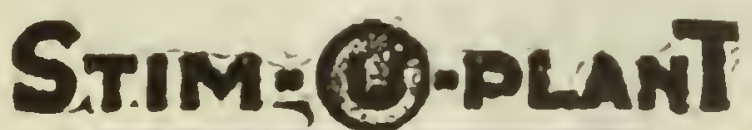

\section{'DLANT STIMULANT' TABLET}

An All-the-Year Fertllizer for Garden and House Plants. Trial size $15 \mathrm{cts} .$, small size 25 cts.. 800 tablets $75 \mathrm{cts} .1 .000 \$ 3.50$

PURE BONE MEAL. This pulverizer ground bone is excellent for rose culture and lawns. It decomposes rapidly and i quickly effective. Slould be applieel a the rate of 400 to 500 pounds to the acre
10 lbs. 60 cts. 50 llos. $\$ 2.50,100$ ibs $\$ 4.25$ 500 lbs. $\$ 21.00,1.000 \mathrm{ll}$ ) $8.50 .00,2.000$ $1 \mathrm{bs} . \$ 75.00$.

SUPERIOR HOUSE PLANT FOOD. A wonderful food for ferns and ulants.

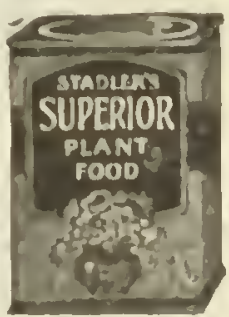
$25 \mathrm{cts.}, 50 \mathrm{cts.}$, and $\$ 1.00$ boxes 


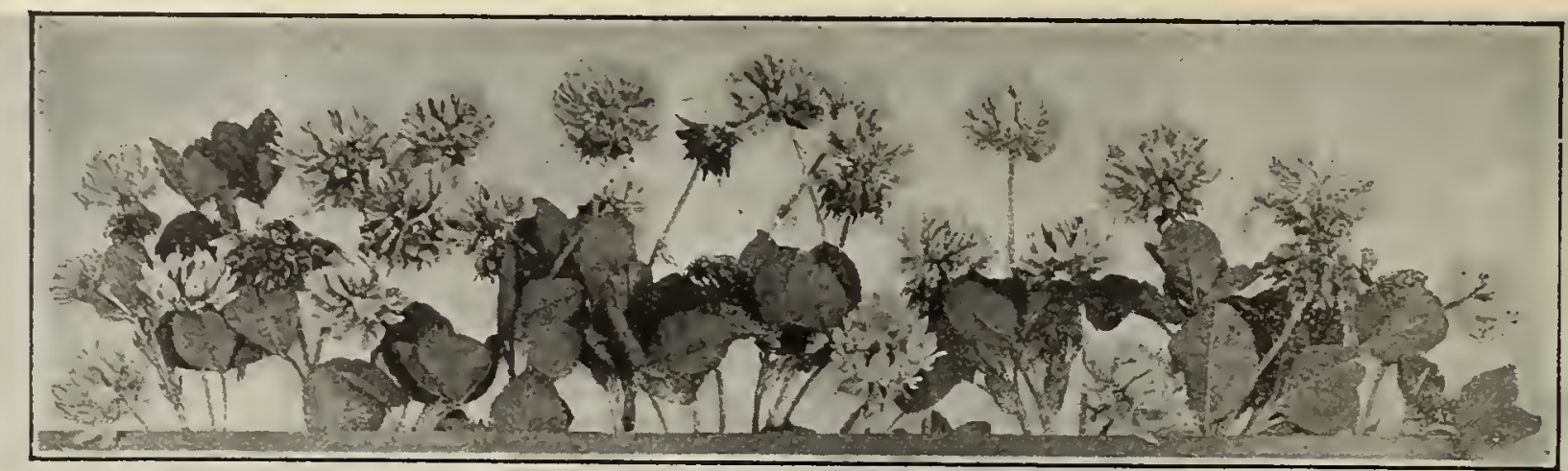

\section{Wyatt's Quality Field and Farm Seeds}

\section{TESTED CLOVER AND} ALFALFA SEED

Our Clovers and Alfalfa can be depended upon, as they are of the highest grade and recleaned. Our seeds are not only of a high-germinating test, but they are of a high purity test, giving assurance to the planter that he will receive the best seeds obtainable. Our Brand means the Highest Quality, the Most Profit and Cheapest for the Planter.

Prices named on clovers are subject to change. Write for prices. Mention quantity wanted and we will fill orders sent us at our lowest prevailing price day order is received.

\section{Red Medium Clover}

(Trifolium Pratense)

This is the common red or "old-fashioned" clover so largely grown; 8 to 12 pounds per acre. Lb. 45 cts., 3 lbs. $\$ 1.35$, postpaid. By express or freight, $10 \mathrm{lbs}$. or more at $40 \mathrm{cts}$. per lb., $\$ 37.50$ per 100 lbs.

\section{Mammoth or Peavine Clover}

(Trifolium Pratense Perenne)

Also known as Sapling Clover. This grows much taller than Red Medium, with larger, leafier stalks; 8 to 12 pounds of seed per acre. Lb. $45 \mathrm{cts}$., 3 lbs. $\$ 1.35$, postpaid. By express or freight, $10 \mathrm{lbs}$. or more at $40 \mathrm{cts}$. per lbs. Write for quantity prices.

Crimson Clover.

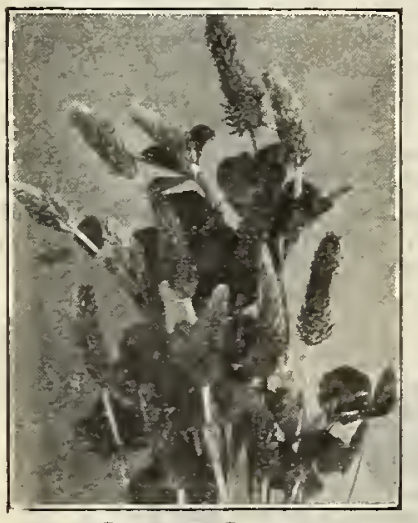

\section{Inoculate this FARMOGERM}

\section{Crimson Clover}

(Trifolium Incarnatum)

An annual variety providing large crops of green forage, or, if cut while in bloom, will make excellent hay. Seed should be sown in August, September, October and November; 20 to 30 pounds per acre broadcast. Lb. 15 cts., 3 lbs. 40 cts. postpaid. By express or freight, $10 \mathrm{lbs}$. or more at $12 \frac{1}{2}$ cts. per lb., $\$ 6.00$ per bu.

\section{Sweet Clover, White Blossom}

(Melilotus Alba)

Biennial. Also known as Bokhara Clover. Plants grow 4 feet during the first season and 6 to 12 feet the second year.; 20 to 30 pounds per acre sown broadcast. Lb. 35 cts., 3 lbs. 95 cts., postpaid. By express or freight, $10 \mathrm{lbs}$. or more at $22 \mathrm{cts}$. per $\mathrm{lb}$.

\section{Bur Clover}

Can only be sown in the summer and fall. For the South it is a most valuable winter grazing crop. Price, seed in the bur: Lb. 25 cts., $10 \mathrm{lbs}$. and over at 20 cts. per lb. Recleaned Hulled Seed: Lb. $50 \mathrm{cts}$., $10 \mathrm{lbs}$. at $45 \mathrm{cts}$. per lb.

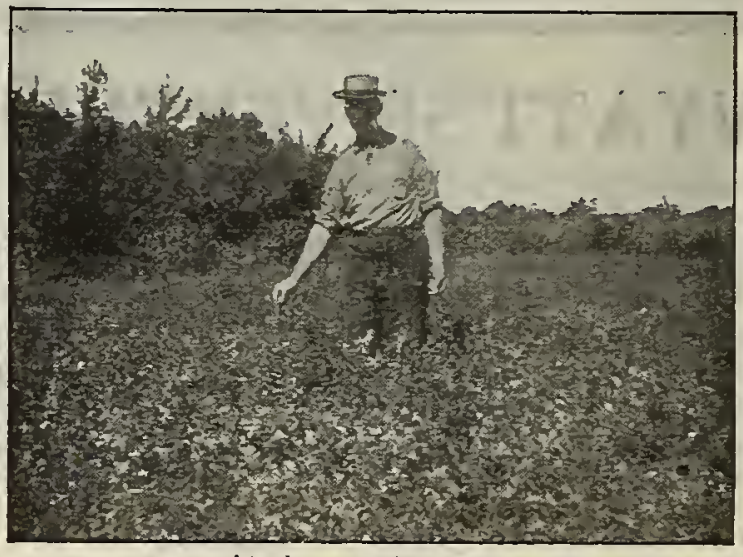

Alralra, or Lucerne.

\section{Alfalfa, or Lucerne \\ The Profitable and Nutritious Hay Crop \\ Inoculate this Seod with FARMOGERM}

Alfalfa, or Lucerne, will produce from 5 to 7 tons of hay an acre each year in the South. Lime should be applied at the rate of 1,500 pounds to the acre. Before sowving the seed it will be best to inoculate them, if Alfalfa has never been grown on the soil you are to sow. Lb. 35 cts., 10 to 30 lbs. at $30 \mathrm{cts}$. per lb., bushel (60 lbs.) $\$ 17.50$

\section{Alsike or Hybrid Clover}

\section{(Trifolium Hybridum)}

A long-lived perennial and very hardy, thriving equally well on wet or dry soils. Sow at the rate of 8 to 12 pounds to the acre. Lb. 40 cts., 3 lbs. $\$ 1.10$, postpaid. By express or freight, at purchaser's expense, $10 \mathrm{lbs}$. or more at 35 cts. per lb. Write for sack prices.

\section{White Dutch Clover}

Is especially valuable and largely used in lawn and pasture mixtures. Lb. $70 \mathrm{cts}$., 5 to $10 \mathrm{lbs}$. at $65 \mathrm{c}$ per $1 \mathrm{~b}$.

\section{Lespedeza, or Japan Clover}

This is valuable to sow on poor wornout fields, hillsides, thin woods, groves, and wet bottom lands for summer pasture and for improving the land. It is particularly valuable for late summer grazing on land that cannot be used for other purposes. Sow 10 to 15 pounds per acre braadcast in March or April and do not graze it early if you wish to re-seed. Lb. $45 \mathrm{cts}$., postpaid. Not postpaid, lb. 35 cts., 10 lbs. at 33 cts. per lb.. 100 lbs. at 28 cis. per $1 \mathrm{~b}$.

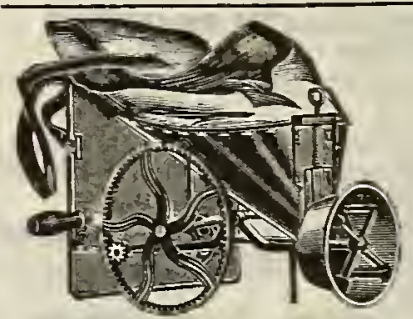

Cahoon Seed Sower wil sow any kind of seeds that are to be sown broadcast, and will do it better than you can by hand; much faster and more evenly. You can average 4 to 6 acres an hour with a Cahoon. No experience necessary; just follow directions. Postpaid. \$5.00. By express, \$4.75. Not Prepaid, 


\section{Wyatt's Pasture and Grass Mixtures}

\begin{abstract}
We have made a study of Grass Mixtures, and in offer. ing the following we have the ideal mixtures for the parposes for which they are recommended. Only the highest grade of seed is used and it is throughly mixed in the proper proportions to give the preper proportions to give the best results. In tures we use only the Grasses which have proven the best to sow together and which mature and ripen together, which is, of course, necessary to get the best crops. Should you desire a special mixture we shall be glad to fill your order.
\end{abstract}

Wyatt's Dependable Grass Mixture No. 1, For Hay or Pasture. Recommended for light. loamy or medium upland, for cither hay crop or grazing purposes. Composed of Orchard Grass. Perennial Rje Grass. Tall Meadow Oat Grass, Red Clover, Alfalfa, etc. These Grasses mature and ripen together, making a splendid hay. Sow 30 to 35 pounds to the acre. Lb. $35 \mathrm{cts.} 10$ lbs. at $32 \mathrm{cts}$. per lb.. 100 lbs. $\$ 30.00$.

Wyatt's Dependable Grass Mixture No. 2, For Hay or Pasture. Recommended for stiff, heavy or low lands. Composed of Kentucky Blue Grass. Alsike Clover. Herds Grass. White Dutch Clover, and Meadow Fescue, etc. Sow 30 to 35 pounds to the acre. Lb. $35 \mathrm{cts.,} 10$ lbs. at $32 \mathrm{cts}$. per $1 \mathrm{~b} ., 100 \mathrm{lbs}$. $\$ 30.00$.

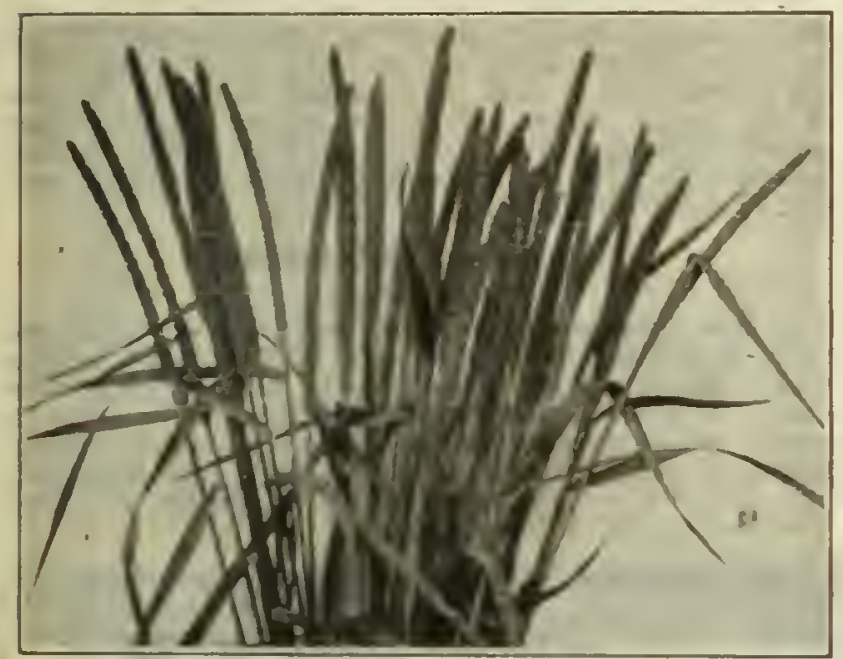

Timothy.

\section{Pure Grass Seed}

Priees subject to market changes. Ask for our cur. rent farm seed prices stating quantities wanted.

Kentueky Biue Grass (Pod pratensis). This grass succeeda best on linestone soil. but dors well on an stit soil. Sow citluer in the fall or spring. 35 to 40 pounds to the acre. Present price: I.b. $55 \mathrm{cts.}$ postpaicl. By expresa. 1b. $50 \mathrm{ct}$.. in lbs. $45 \mathrm{cts}$. per $1 \mathrm{~b} . .100$ lbs. at $42 \mathrm{cts}$.

Tall Meadow Oat Grass (drena elatior). Sriw 50 ponule to the acre. I,h. $45 \mathrm{cts.}$ post paid. Bushel (10 lbs.) $\$ 3.00$. $10011 \mathrm{~s} . \$ 22.50$

Crested Dogtall (Cynosurus cristalus). 30 Ihs. to thu acre. Lb. $60 \mathrm{cts.}$ postpaid. [3usliel (21 11)s.) $\$ 11.50$ 100 lbs. $\$ 50.00$.

English Rye Grass, Perennial Rye (Jolium perenne). Snw 60 ths. to thr acte. 1,b. $35 \mathrm{cts}$. yost paid. Bushel (24 1bs.) \$4.7.5. 100 ibs. \$18.00.

Timothy (Phleum pralense). Thrives hest on lienvy noist soils; should not be sown on light dry land. L.b. $20 \mathrm{cts.}$ in liss. at if cta. per lh.. bushel ( $\$ 5 \mathrm{lhs}$ ) $\$ 7.00$.
Canada Blue Grass (Poa compressa). Useful for sowing on liard clay and poor soils. Weight per bu. it lbs. Lb. $50 \mathrm{cts} .10 \mathrm{lbs} . \$ \$ .50,100 \mathrm{lbs} . \$ 40.00$.

Red or Creeping Feseue (Festuca rubra). For lawus it is unsurpassed and should be inclucled in all shacle mixtures. Lb. $\$ 5$ cts., 10 lbs. $\$ 7.00 .100$ lbs. $\$ 65.00$.

Rhode Isiand Bent (Agrostis temuis). One of the bes grasses for lawns. Weight per bushel $1+$ lus. 1,b. \$1.75 10) lbs. at $\$ 1.50,100 \mathrm{lbs}$. at $\$ 1.45$

Italian Rye Grass (Lolimm Ilalicum). Taluable for pas ture nuixtures. $50 \mathrm{lbs}$. to the acre. 1,b. $35 \mathrm{cts}$. postpaid Busliel (18 lbs.) $\$ 3.75$, 100 lbs. $\$ 1 \$ .00$

Orehard Grass (Doctylis Glomerald). One of the most val wable of the pasture grasses: makes a good hay. Sou 3 bushels to the acre. Lb. $35 \mathrm{cts}$. postpaid. Buslue (14 libs.) $\$ 4.00,100$ llos. $\$ 22.00$.

Meadow Feseue (Festuca protensis). English Blue Grass. or Sweet Grass. Sow 40 llas. to acre. 1.b. $30 \mathrm{cts}$. postpaid. Bushel (22 lbs.) $\$ 5.50$, 100 lus. $\$ 20.00$.

Bermuda Grass (Cynodom dactylon). A valuable grass for permanent sod. Would not advise sowing on land wlich is to le planted in other crops. as it is very tenacious in habit and very hard to eradicate after it once gets a hold. It is very similar to Virginia IVire Grass. Sow in March or April, 15 lis. to the acre in well prepared soil. Lb. $60 \mathrm{cts.,} \mathrm{postpaid.} \mathrm{13y"} \mathrm{express.}$ 1b. 55 cts.. 10 lus. at 52 cts. a lb.. 100 lbs. at $50 \mathrm{cts}$.

Red-Top, or Herd Grass ( 1 grofis rulgaris). Suitable for meadow, also lawns and pasture. Sow 3 to 4 bushels per acre for lawns: for pasturt, ity to 3 bushels per acre. L., 50 ct... postpitid; 10 11,s. \$4.50, sack of 50 Hos. $\$ 21.00,100 \mathrm{lbs}$. $\$+10.00$.

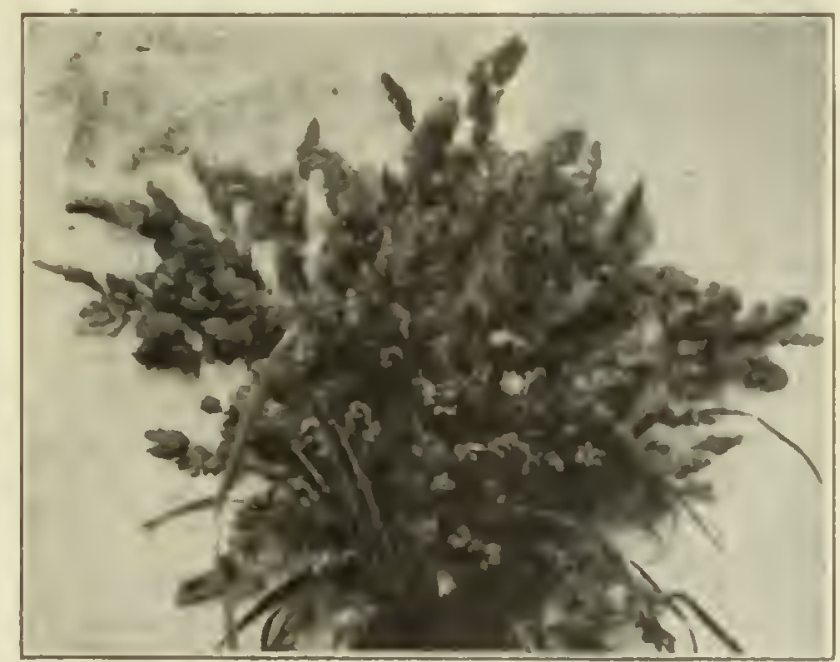

Orchard Grass.

We hamble over 5,000 bughris of Cownens amually. W'rite us for prices when you dre realy to buy, or we will buy peas. Semul samples for nur pricis.

PRICES-Account of catalog going to press before spring market has been established on all field seeds, we are unable to quote quantity prices. For current prices write us. 


\section{Dwarf Essex Rape \\ Makses Splendid, Nutritious Pasturage for Cattle, Sheep, Hogs and Poultry.}

This crop is very highly recommended for pasturage for cattle, sheep, and hogs, furnishing most rich and nutritious pasturage within six to eight weeks from the time of sowing. The fattening properties of Rape are said to be very much better than those of clover. It also makes splendid green feed for poultry. In this section Rape can be successfully sown in the spring and fall. Rape is best sown in drills, at the rate of 3 to 5 pounds per acre, or it can be broadcast, when $10 \mathrm{lbs}$. per acre should be used. Lb. 25 cts., (postpaid, lb. 35 cts.), 10-1b. lots and over at $15 \mathrm{cts}$. per lb., 50-1b. lots and over at 12 cts. per lb., 100 lbs. at $10 \mathrm{cts}$.

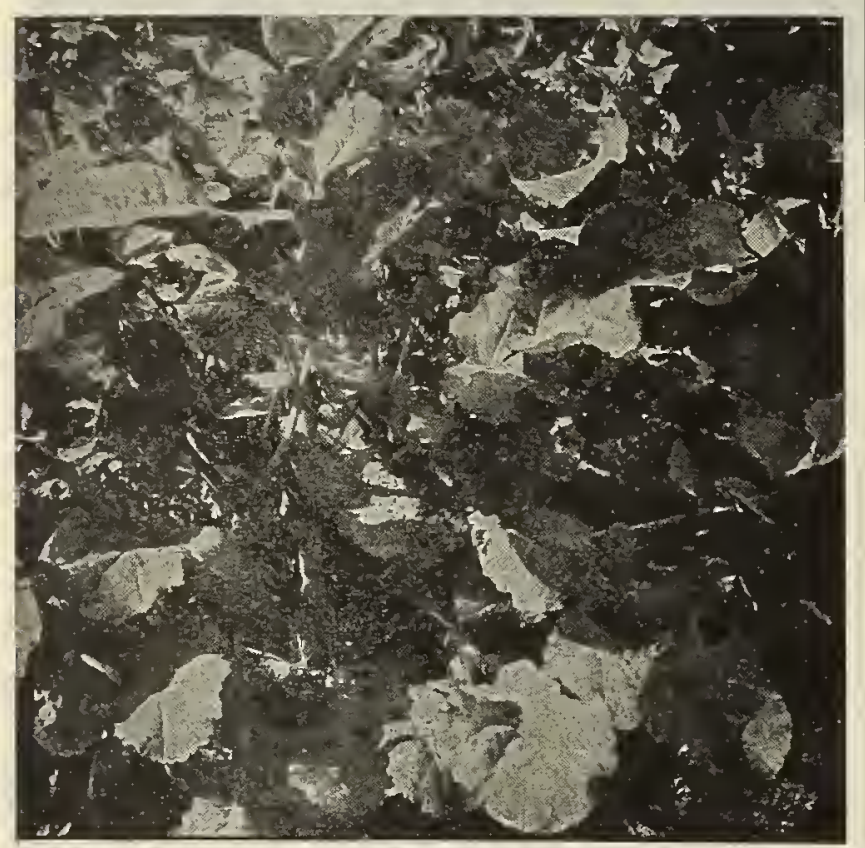

Dwarf Essex Rape.

\section{Yellow Milo Maize}

This crop is grown like corn, and may be cut several times for green forage; also used for ensilage, or cured like sorghum. Use 4 to $5 \mathrm{lbs}$. per acre. Grows to a height of 8 to 10 feet. Lb. 35 cts., postpaid. By express or freight, at purchaser's expense, 5 lbs. 60 cts., 10 lbs. $\$ 1,50$ lbs. $\$ 4$.

\section{Broom Corn}

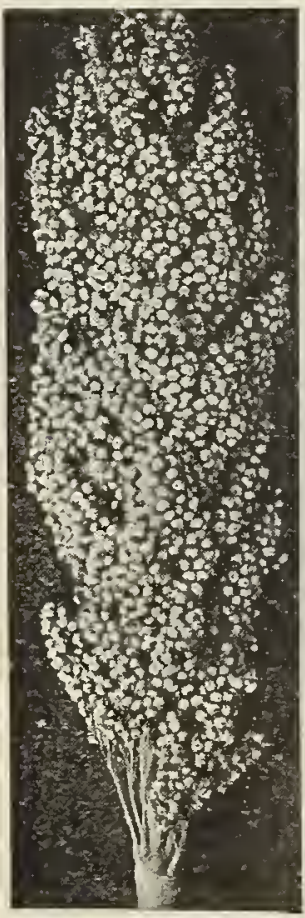

Evergreen. Grows. long and straight; brings highest market prices for making brooms. Sow in 3 -foot drills and thin plants to 3 inches. Sow 5 pounds to the acre. Present price: Lb. $25 \mathrm{cts}$. 10 lbs. $\$ 1.80$.

\section{Sweet-Scented \\ Vernal Grass}

(Anthoxanthum odoratum)

True Perennial. Emits an agreeable odor which it imparts to hay or to lawn when being cut. Sow only in mixtures, using 2 or 3 pounds per acre. Lb. $\$ 1.00$. Write is for prices on larger quantities.

\section{Kaffir Corn}

The grain is much relished by cattle and poultry. It can be sown with cowpeas; the corn holds the vines off the ground, making a larger yield of peas, and both can be cut together, making larger yield of feed. Sow alone broadcast 40 to 50 pounds to the acre for forage; and cut before fully headed. Lb. 25 cts., postpaid; not postpaid, 10 lbs. at 15 cts. per lb., 50 lbs. $\$ 4.00,100$ lbs. $\$ 7.50$.

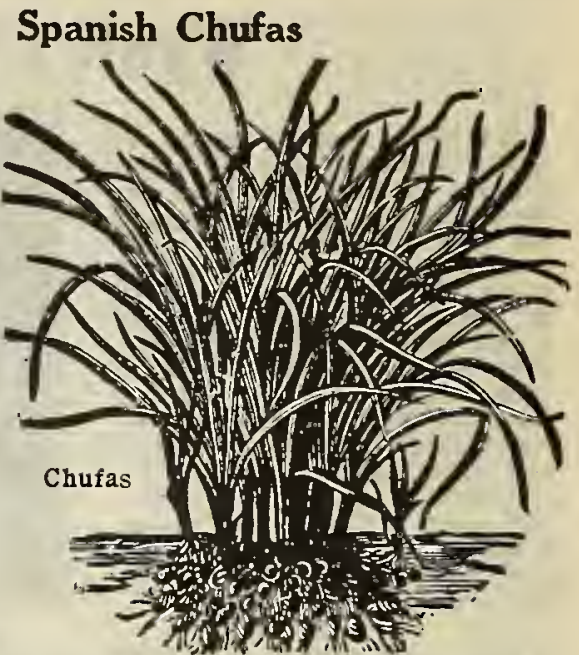

They can be planted from April to June Make rows $21 / 2$ to 3 feet apart, dropping from three to five $\mathrm{Chu}$ fas together, 15 to 18 inches apart in the row, coverering about 2 inches. Chufas require from 1 to $1 \frac{1}{2}$ pecks per acre.

When it is desired to turn hogs into them, pull up a few of the hills by the roots and leave them on top of the soil and when either hogs or chickens get a taste of them they will quickly go over the field in search of them. Lb. 30 cts., postpaid. Pk. $\$ 1.50$, bu. (40 lbs.) $\$ 5.75$.

\section{Sunflower}

Large Russian. This bears large heads, frequently 12 to 20 inches in diameter and sometimes yielding 1,000 pounds of seed per acre. The seed is used for feeding chickens and parrots. Use 3 pounds of seed per acre sowing in rows 5 feet apart and thinning to 1 foot. Lb. 25 cts., 5 lbs. $\$ 1.00$. Write for prices in quantity.

\section{Teosinte}

\section{Reana Luxurians}

A forage plant somewhat like corn. The seed should not be sown until all danger of frost is past. If cut for green forage, which can be done at any stage during growth, two or more joints should be left at the base of the stalk. These will sprout out quickly into fresh growth, making an even larger crop than at first cutting. Sow in drills 4 feet apart, using 4 pounds of seed per acre. Lb. 70 cts., 10 lbs. $\$ 6.50$.

\section{Paspalum Dilatatum}

(Dallas Grass)

A new grass for hot, dry climates. A hardy perennial from Australia, growing 5 feet high without getting tough, and seems to be particularly adapted for grazing dairy cattle. The seed requires about three weeks of moist, genial weather to germinate it, but once established, it seems to stand anything. Sow 8 or 10 pounds per acre. Lb. 65 cts., 10 lbs. at 55 cts., 50 lbs. at $45 \mathrm{cts}$. 100 lbs. $\$ 40.00$. Prices fluctuate.

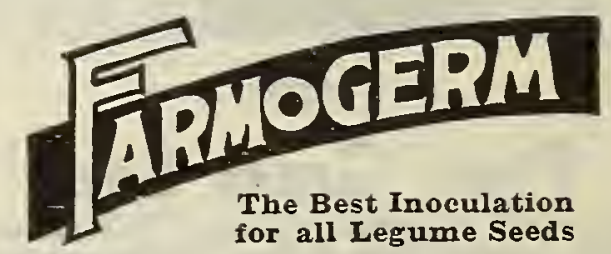

FARMOGERM, the "Always Fresh" Inoculant

A pure culture of nitrogen-fixing bacteria of highest quality. By reason of the patented stopper, which admits air and excludes contaminations, FARMOGERM is guaranteed for five years-always fresh-always strong and virile.

A different culture is required for each legume group, so when ordering, be sure to state what crops you wish to inoculate.

\section{New Low Prices}

For Small Seeds-Clovers, Alfalfa, etc.

$1 / 4$-bus. size....\$0.35 1 -bus. size.... \$1.00

$1 / 2$-bus. size..... .60 $21 / 2$-bus. size..... 2.25

10 bus. size....... 8.00

Special reduced prices on Cultures for large size seeds, Soy Beans, Cowpeas, Peas, Beans, etc.:

$1 / 2$-bus. size....\$0.35 1-bus. size......\$0.60 5-bus. size........ 2.25

Special garden size for Garden Peas, Beans, and Sweet Peas, 25 cts. 


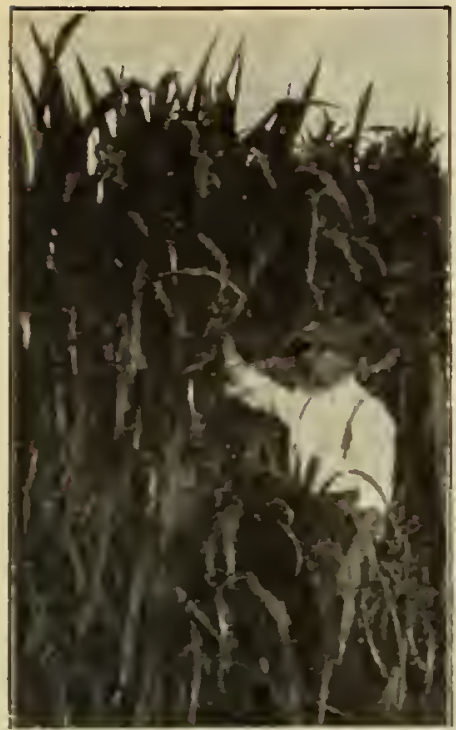

Sudan Grass.

The Best Quick Growing Feed Crop for the Carolinas.

\section{Sudan Grass}

It yields from 2 to 8 tons of hay per acre, depending upon sufficient moisture. Two cuttings are assured and in places four have been taken. The hay is of superior quality and relished by all stock. Plant late in spring after frost is past. If drilled in rows 36 inches apart, you will require 2 to 4 pounds of seed to the acre: if seeded in rows 18 to 20 inches apart, 4 to 6 pounds; if broad cast, 15 pounds. Lb. 20 cts.. 10 lbs. $\$ 1.60$. 50 lbs. at $15 \mathrm{cts}$. per $\mathrm{lb}$ 100 lbs. $\$ 12.50$

\section{Peanuts}

Plant in May or June 12 inches apart, in 3-foot drills. About 1 bushel in the hull is required to plant an acre, and about 15 pounds shelled nuts. Cultivate lat, keep well worked. Peanuts should be shelled before planting.

Spanish. Nuts small, and have a thin hull. They are early to mature, very productive, and in the tar South, where they can be planted during March and April. two crops can be made noculate thi FARMOGERM and roots make excellent food for in one year. The vine and rots. (postpaid, 25 cts.) 10 lbs. at $18 \mathrm{cts}$. per $1 \mathrm{~b} ., 100$ lbs. $\$ 16.00$; shelled. $1 \mathrm{~b} .25 \mathrm{cts}$. (postpaid, 35 ets.). 10 lbs. at $20 \mathrm{cts}$. per lb.. 100 lbs. $\$ 17.50$.

Valeneia. These are dull red in color, of medium sizc. A heavy yiclder with long pods, sometimes containing thrce or four peanuts. It is probably the hardiest Peanut in cultivation. Lb. $20 \mathrm{cts}$ (post paid, $30 \mathrm{cts}$ ), 10 lbs. at $18 \mathrm{cts}$. per lb., 100 lbs. $\$ 15.00$.

Virginia Jumbo. A large varicty of the well-known Virginia Peanut. In the hull, lb. $20 \mathrm{cts}$. (postpaid, 30 cts.). 10 lbs. at $18 \mathrm{cts}$. per lb.. 100 lbs. price quoted on request.

\section{Carpet Grass}

This is one of the most valuable pasture grasses for this section. Good for lawns. Sow 10 pounds per acre. Lb. 60 cts.. 10 lbs. $\$ 5.50,25 \mathrm{lb}$. lots at $52 \mathrm{cts}$.

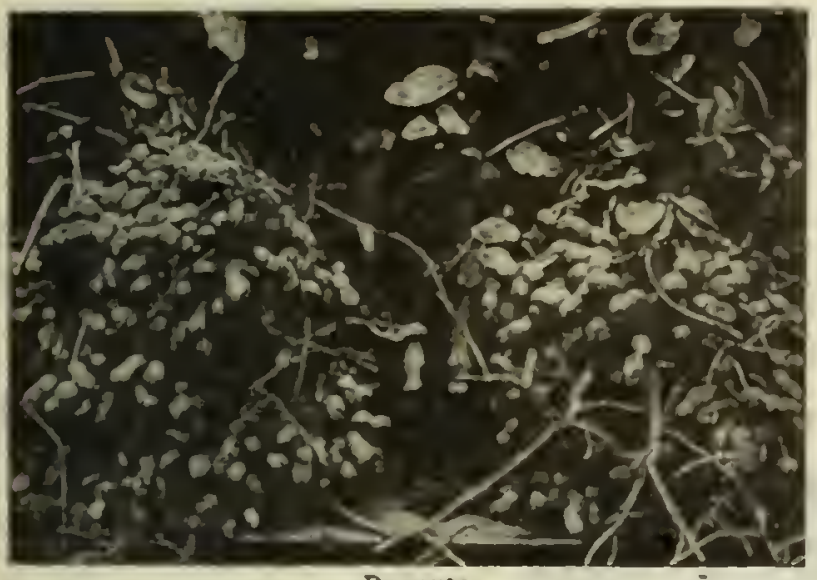

Peanurs.

\section{White Beans}

Navy. Can be planted during the summer months, and when dry stored for winter use. Beans small and pure white. Very prolific. I.b. $30 \mathrm{cts} .$, postpaid; 100 lbs. at $121 / 5$ cts. per lb.

White Kidney. Similar in growth and use to the Navy. but larger and kidney-shaped. Makes a choicc cating bean. Very prolific. Lb. $35 \mathrm{cts}$., post paid; 100 lbs. at $20 \mathrm{cts}$. per lb. Write for prices on bulk quantitics.

\section{Cane, or Sorghum}

All Varieties Cane: 10 lbs. $\$ 1.25,100$ lbs. $\$ 10.00,500$ lbs. at 8 cts.

Texas Seeded Ribbon Cane. This cane gets its name from being a variety that closely resembles the true Ribbon Cane. Price, 1 lb. 30 cts., parcel post paid.

Early Orange. It is from 8 to 10 days later than the Early Amber, and produces a syrup of excellent quality. Price: Lb. 20 cts., 2 Ibs, 35 cts.. parcel post paid.

Early Amber. Early Amber is the most valuable fodder plant in existence. Is but little affected by drouth. Price: Lb. 20 cts., 5 lbs. 75 cts. parcel post paid.

Sugar Drip. It is also one of the best varieties for making syrup, giving an immense quantity, as well as.the very best quality. Sow broadcast at the rate of 1 bushel per acre. Lb. 30 cts., 2 lbs. 50 cts., 5 lbs. $\$ 1.00$. postpaid. Writc for prices on bulk quantities.

\section{Velvet Beans}

\section{Dollehos}

Multifiorus

They are equally as nutritious as Cowpeas, arc largely used both for grazing and as a forage crop throughout th $\mathrm{e}$ Soutli. It is mucl better, if possible. to leave them above ground until killed by frost. then to plow under in the winter or carly spring, at which time they will make a heavy matted coating of vegetable matter. These should be planted in May. Junc, or July, at the rate of $11 / 5$ pecks to the acre. in drills 5 feet a part.

Oseeola Velvet Beans. Price on application, usually a bou

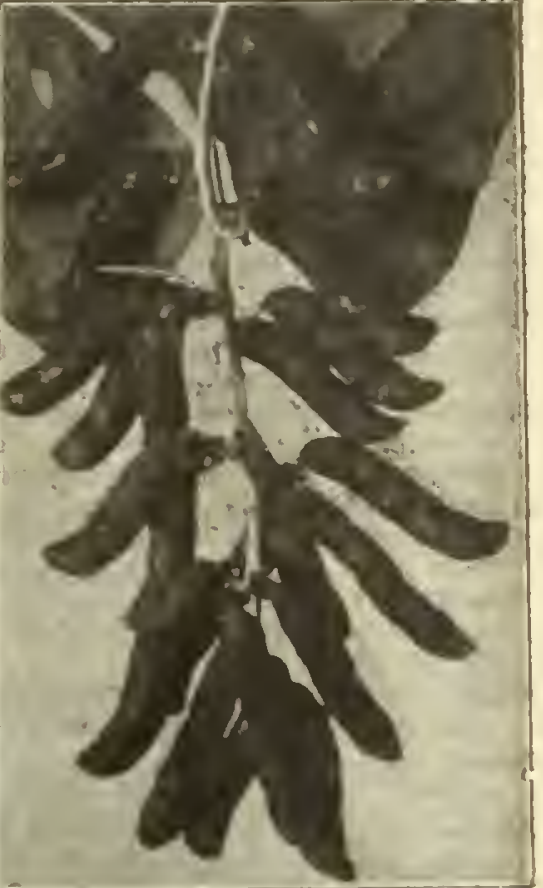

Volvet Beans.
$\$ 1.25$ per peck. $\$ 4.00$ per buslel.

Early Speckled or 100-Day Velret Beans. I'rice on application, about $\$ 1.25$ per peck, $\$ 4.00$ per bushel.

\section{Georgia Bush Velvet Beans}

The upright bush grows $31 / 5$ fcet high with limbs branching from the bottom.

Stock like it better than the vining varietics. The sced is a little smaller and darker than the seed of the 100-daySpeckled Velvet Bean.

For hay. sow one bushel broadcast per acre in May or June. In the corn plant about April 15th. I'rice: Qt. 50 cts., post paid; bu. about $\$ 5.00$, not prepaid.

\section{Table Cowpeas}

All varicties exeent where noted, present price, about 50 ets. per qt., \$1.75 per pk.. \$6.50 per bushel.

Brown-Eye White Peas. This is a wcll-known Pca in the Carolinas. It has a purple luull and is a tremendous y'elder.

Large Early Blaek-Eye. The nods are long and well filled with large, pure white Peas with a coal-black evc. Price about $\$ 6.50$ bu. Write for prices on bulk quantitics.

Small Black-Eye. The seeds are of beautiful sliape and color, very small, and of the most sclect cating qualitics.

Crowder. A new Pea that we put ahead of any for table use. Its color is a light brown. The sceds arc large or medium size, irregular shape and of the most choice Ravor. Its eating qualitics are far superior to those of any other variety. $\mathrm{gt} .75 \mathrm{cts}$. 


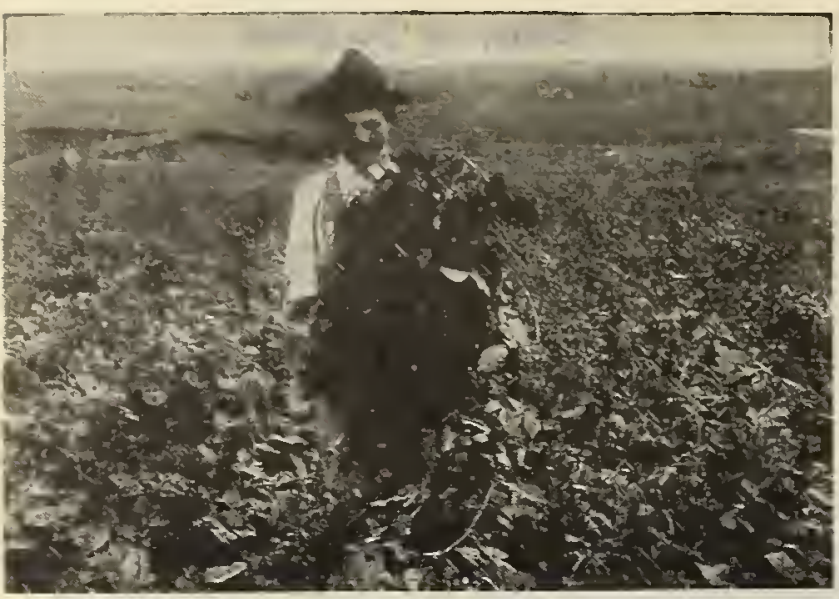

Whippoorwill Cowpeas.

\section{Cowpeas (Vigna sinensis)}

Sow 60 to 90 pounds of seed to the acre.

The vines when cured are considered superior to timothy hay' in the South. As a fertilizer the Cowpea has no superior, for, to a greater extent than any other leguminous crop, it has the power of extracting the nitrogen from the air and depositing it in the vines and roots, so that the land is benefited even when the crop is cut for hay. Sow from middle of May to the tenth of August.

Whippoorwill. A favorite, early, upright growing variety, more largely used and sold than any other kind. Has brown-speckled seed, which are easily gathered.

Wonderful or Unkmown. A variety valuable on account of its immense growth of vines. It is late in maturing and needs a full season to give good results.

Braham. It is disease resistant, and heavy yielder of both seed and hay. The seeds are small. One bushel will go twice as far as any of the older varieties.

New Era. It is quicker in growth than any other Cowpea; makes a very large growth of vine and a very prolific yielder of Peas.

Clay. Seeds medium-sized and cream or clay-colored. Vines grow long and leafy. Seed matures medium late.

Black. It is very prolific, early to mature, makes a fine growth, both of vines and a good yield of Peas.

Iron. This variety is noted for its disease-resistant qualities. The seed is smaller than the average Cowpea.

Red Ripper. The Red Ripper resembles the Black Cowpea in growth of vine, but is ten days earlier and more prolific.

Mixed Cowpea Seed. The principal varieties in the Mixed Cowpeas we offer are the Clay, Black, Red Ripper. Whippoorwill, and other southern varieties. A great many southern farmers prefer to sow Cowpeas in mixture as they grow thicker, producing a better crop of vines and forage than sowing single varieties alone.

All varieties of Cowpeas, present price: pk. $\$ 1.50$, bu. $\$ 5$.

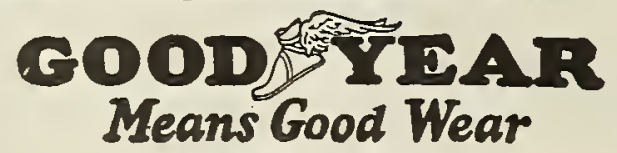

Rubber Hose

$3 / 8$-in. Spray Hose...20 ft . $5 / 8$-in. Garden Hose, $20 \mathrm{ct}$. \begin{tabular}{l|l}
$1 / 2$-in. Spray Hose...25c ft. & $5 / 8$-in. Garden Hose, $20 \mathrm{cft}$-in. Goodyear Elm $15 \mathrm{c} \mathrm{ft}$.
\end{tabular}

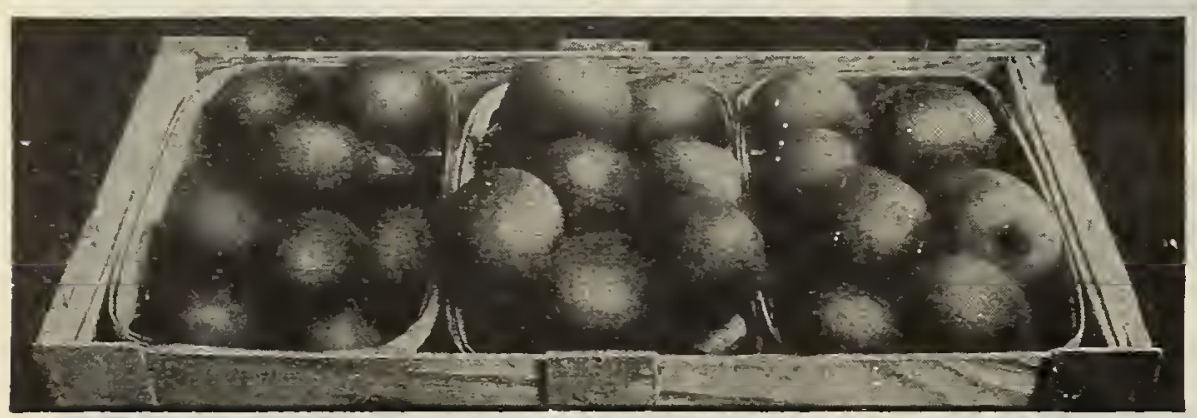

A good package improves the appearance of your fruit or vegetables, which means better prices.

[ 50 ]

\section{Vetches}

Sand, Hairy or Winter. Sow from July to December, preferably with grain, which will hold the Vetch off the ground. Sow 25 lbs. to the acre with grain. Lb. 25 cts., 10 lbs. $\$ 1.75,100$ lbs. $\$ 15.00,500$ lbs. at 14 cts. lb.

Oregon or Spring. Larger seed and coarser growth than the Hairy Vetch; may be sown either in spring or fall. 25 lbs. to the acre with 2 bushels of Oats, which will make excellent early hay. Lb. 22 cts., postpaid; by express or freight, lb. $12 \frac{1}{2}$ cts., 100 lbs. $\$ 10.00$.

\section{Steel Garden Weeder}

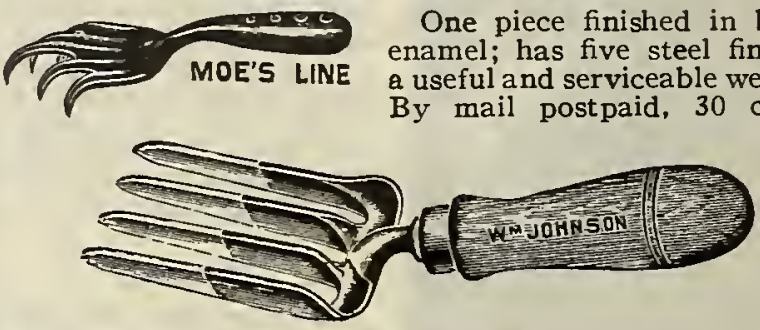

Four-Tine, A good and serviceable fork, but not the equal of the 3-tine. Finished in red enamel, polished points, hardwood handle. Length 10 inches; forks $31 / 2$ inches. By mail postpaid, 35 cts.

No. 200. Ideal Weeders. 35 cts. each.

\section{Grass and Sheep Shears}

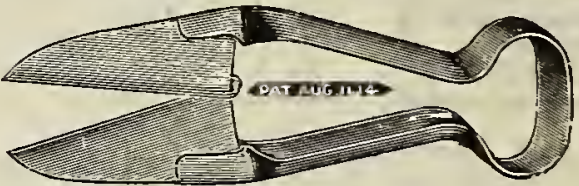

75 cts. per pair; 85 cts. postpaid.

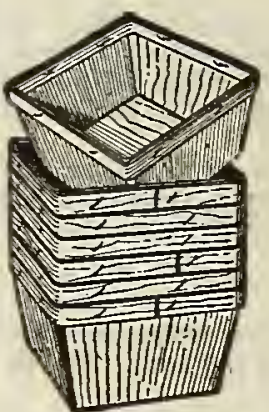

FRUIT BASKETS

For packing berries and fruits. Per $100 \quad 1.000$ 1 -pint size (oblong) ....\$1.40 \$12.00 1 -quart size (square)... $1.50 \$ 12.50$ 2-quart size (oblong) ... $1.90 \quad 17.00$ 3-quart size (oblong)... $2.75 \quad 26.00$ 4-quart size (oblong)... $3.00 \quad 27.00$

RACKS-For separating layers of fruit baskets in the crate, $\$ 3.00$ per 100.

PEACH or TOMATO SHIPPING CRATES-Holds $6-4$-qt. baskets in knock down. Each $50 \mathrm{cts}$.

SELL EGGS BY MAIL

To Your City Friends Shipped in Aluminized

\section{METAT EGG CRATES}

Indestructible; pays for itself in a few shipments; làsts for years; makes interchangeable shipping easy. Buy yours now and realize more money for your eggs. Your friends want them.

The Metal Edge Filler is wonder. $A^{\circ}$ new invention and can$\mathrm{n}$ ot be

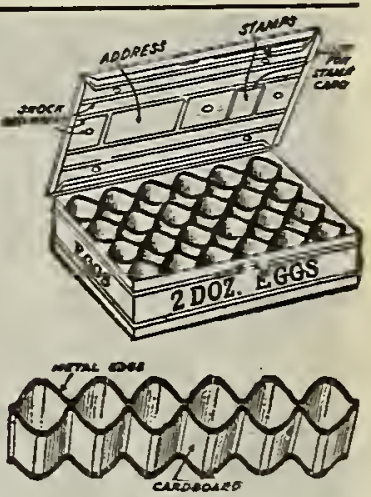
safely carrying Eggs by mail. Light safely carrying Eggs by mail. Light
in weight but strong.

Write us about Butter-Egg Crates. PRICES

2-dozen size ............\$1.50 3-dozen size ............... 1.75

4-dozen size ............... 2.00

6-dozed size ................. 2.50

Add postage for 3 lbs. to the price for each 150 miles.

Garden Lemon, Pineapple Casabs (Winter), Vegetable Or. ange, or Vine Peach. Pkt. 15 cts., 1 oz. 35 cts. 


\section{Millet}

Pearl or Cat-Tail Millet. It grows rapidly, and will attain a height of 12 feet. but we advise eutting several times, rather than allowing it to mature. It will continue to grow until killed by freezing weather. Sow 5 pounds of seed per acre in dirlls 3 feet apart, or sow broad cast at the rate of 20 to 30 pounds per aere. Crop very short. Pkt. 10 ets., Ib. 25 cts. (postpaid, 35 cts.). 10 lbs. at 23 cts. per lb., 100 lbs. at 22 ets. per lb.

Golden or Liberty Millet is deeidedly one of the best varieties to grow for a hay crop; produces large crop of fine grass ranging in height from $43 / 4$ to $6 \mathrm{ft}$., according to strength of soil. Can be eut green or made into hay, and is readily eaten by stock. It requires 1 bushel to sow an acre broadeast. Lb. 15 cts.. 10 lbs. at $121 / 2$ ets. lb.. 50 lbs. and over at 8 ets. per lb. Not prepaid.

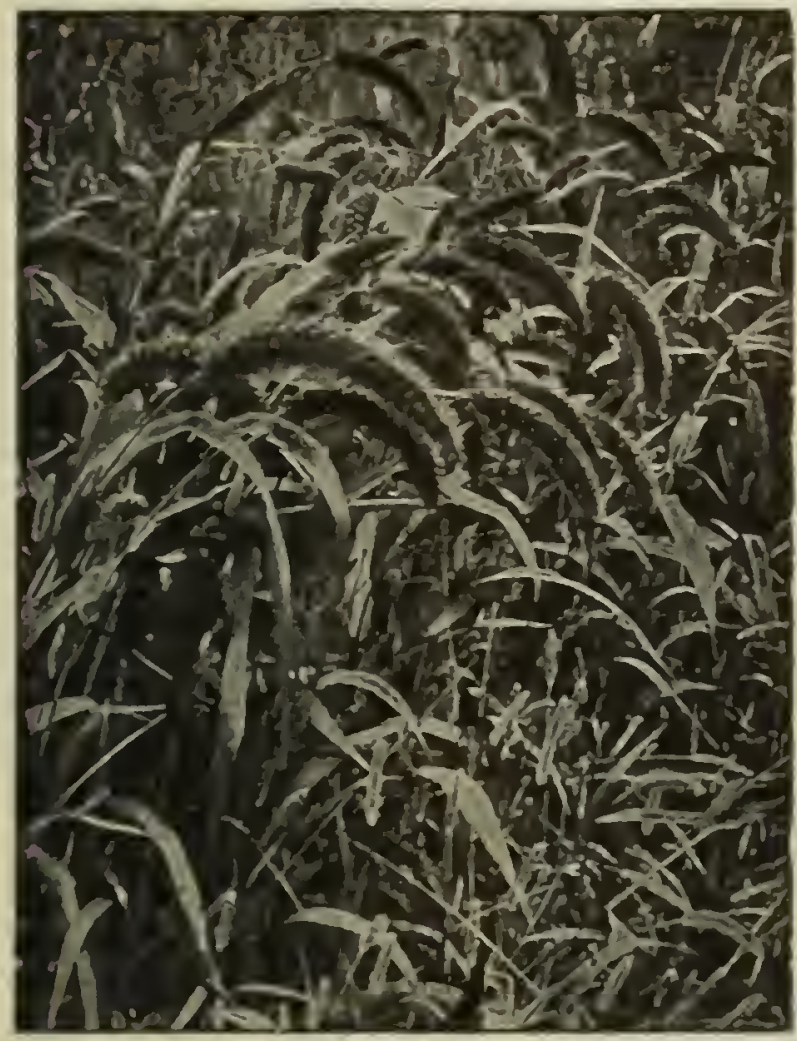

Golden Millet.

\section{Seed Wheat}

Red May, Purple Straw or Blue Stem, Leap's Prolife and Fultz. Bu. $\$ 2.50,10$ bu, at $\$ 2.35$ per bushel.

\section{Winter Rye}

Common Winter. Bu. \$1.75. Rosen. Bu. $\$ 1.75$. Abruzzi. Bu. \$2.75.

\section{Oats}

Burt or 90-Day. The best spring Oats, as it is the carliest, nearly rust-proof, lardy and vigorous and yiclds more grain than any spring (rat. Sow 2 bushels to the aere. Present price: Bu. \$1.20, 5 bu. $\$ 5.5 n$.

Virginia Gray Winter or Turf. Though a winter Oat. it also sueceerls well if sown in the spring. makins surest erop if sown by Mareh 15 . Sow 1 if to 2 bushels to the aere. Bu. $\$ 1.70,10$ bu. at $\$ 1.60$.

Red Rustproof. A very desirable early variety for heavy soils and low. moist grounds. where rust attacks other varietica. Yields abundantly of large, heavy grain. but does not grow as tall as the winter mat. Sow 2 bushels to the arre. Present priee: $13 \mathrm{u} . \$ 1.20,5$ bu. $\$ 5.50 .23 \mathrm{bu}$ at $\$ 1.00$.

Appler. An early, large red Oat. similar to the Rustproof. but harlier anrl yields more grain. I'resent price Bu. \$1.20. 10 bu. at $\$ 1.15$ per bu.

Fulghum. This Oat is of a rustprof type, somewlat earlier than the Appler, and is a heavier yiclder. Is largely used in the South. Present price: Bu. \$1.25. 5 bu. $\$ 6.00 .10$ bu. at $\$ 1.20$ per bushel.

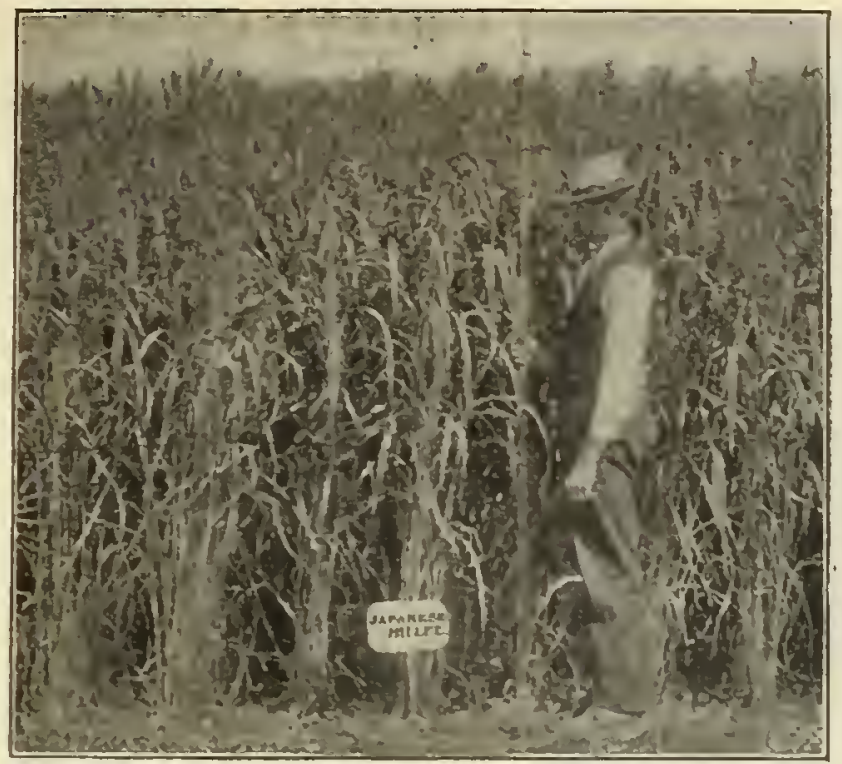

\section{Japanese Millet-Billion Dollar Grass}

It has a marvelous, luxuriant growth, often reaching 6 feet in height and producing an immense amount of hay of great feeding value which is keenly relished by stoek Speeially adapted to the low, wet ground. Best sown in drills, using about 10 pounds of seed to the acre-but sometimes sown broadcast, when 15 pounds per acre should be sown. Lb. 25 ets. 10 lbs. \$1.75. Write for prices on larger quantities.

\section{Barley}

Bearded【Winter. Bu. $\$ 2.50$, Spring.? Jliu. $\$ 2.50$.

\section{Japanese Buckwheat}

This is a profitable crop for either grain, flower food for bees. soil-enricher. or to kill out weeds. Splendid for poultry. Sow I bushel to the aere in June. July, or August. Price, about $\$ 3.00$ per bu.

\section{Canada Field Peas}

Canada Field Peas should be sown in February or March. weather permitting. They make large yields of nost num. tritious hay. eut either green or cured for hay. They. should be sown 1 to 11,3 bushels per acre. with i bushel Spring Oats. Pk. \$1.25, bu. \$5.00. Cotton bags $50 \mathrm{cts}$.

On aecount of their extreme hardiness, they can be sown earlier than any other lesume crop. furnishing an excellent crop of hay or serving the purpose of a sreen fertilizer.

\begin{tabular}{|c|}
\hline $\begin{array}{l}\text { Long Handle Pole Pruning Shears } \\
\text { With } 8 \mathrm{ft} \text {. Pole } \ldots . . . . \\
\text { With } 10 \mathrm{ft} \text {. Pole...................... } \$ 4.75\end{array}$ \\
\hline $\begin{array}{l}\text { Disston No. } 1 \text { Tree Pruner } \\
\text { With 27\% inch Handles, each................ } \$ 3.00\end{array}$ \\
\hline $\begin{array}{l}\text { Disston No. } 5 \text { Utility Pruner } \\
\text { Price, cach }\end{array}$ \\
\hline
\end{tabular}

Carrotg are excellent in soups or grated and sdded to the salad as well as served as a vegetable. There is a sear-round rlemand for carrots on your local market.

SPECIAL COLLECTION OF FLOWER SEEDS

For those who are not familiar with the best aummer-flowering annuals, quiek-growlng ellmbers, cte. we have collections of tlic best. 12 pkts. for 50e.

Calf Meal. It makes calveg grow. \$1.50 per sack. Postage 30 cts. extra. 


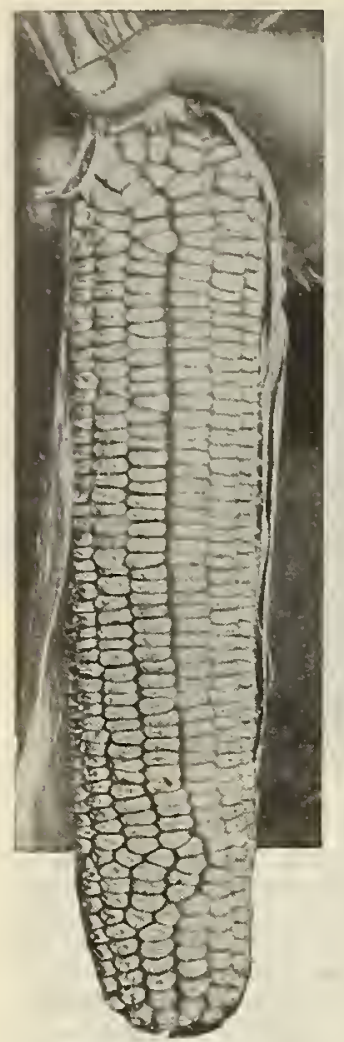

FIELD CORN

Wyatt's Improved Golden Dent.

We have been carefully growing and selecting this Corn on our own farms for several years, until now we have in it the most prolific and hardy yellow Corn to be had for the South. It is very early, maturing in about $90^{\circ}$ days. Present price: 4 qts. 65 cts. pk. $\$ 1.00$, bushel $\$ 3.25$.

Red Cob White Gourd Seed. A very deep-grained Corn, with large ears and medium cob. One of the most popular Corns for medium or light land. Present price, Pk. $\$ 1.00$, bu. $\$ 3.25$.

Blount's Prolific. One of the largest yielding varieties for the South, producing 3 to 6 ears of white, flinty Corn to the stalk. Makes excellent meal. Pk. $\$ 1.25$. bu. $\$ 3.25$.

Boone County White. Ears well filled out at both ends, cylindrical, 9 to 11 inches long, averaging 20 rows, some 18 and 22 . Grain very deep, a little rough. Cobs white, of medium size. Pk. $\$ 1.00$, bu. $\$ 3.00$.

Prolific corn.

Cockes Prolific. (140 days). On land of good fertility, it may be relied upon to produce from two to four ears to the stalk. The ears are of good average size, the grain being white, of flinty nature, making an excellent meal or hominy Corn. By express or freight, qt. 25 cts., pk. $\$ 1.00$, bu. $\$ 3.25$; by mail, postpaid, pkt. 10 cts., qt. 40 cts.

Early Northern White Dent. For early ripening, large yield and compact growth, is one of the best varieties; ears large, from 14 to 18 -rowed. Qt. 25 cts. 4 qts. 75 cts., pk. $\$ 1.00$, bu. $\$ 3.25,5$ bu. at $\$ 3.00$ per bu.

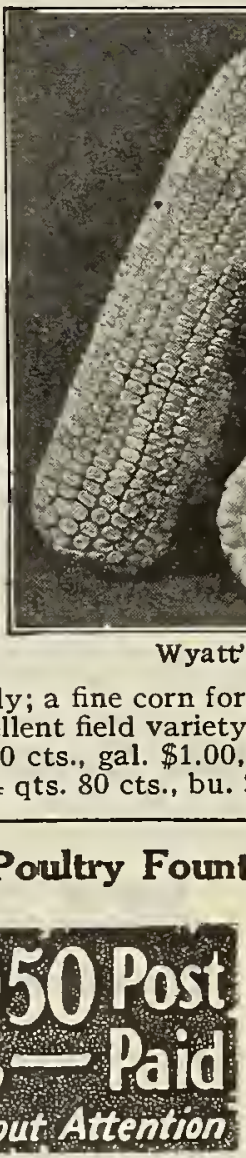

This little device will keep water from freezing in zero weather. Burns a month without filling or trimming. One cold day with water frozen may stop egg production for a month.

A Little Putnam Stove is also used to heat home-made oat sprouter. Plans for making sprouter packed with every stove.

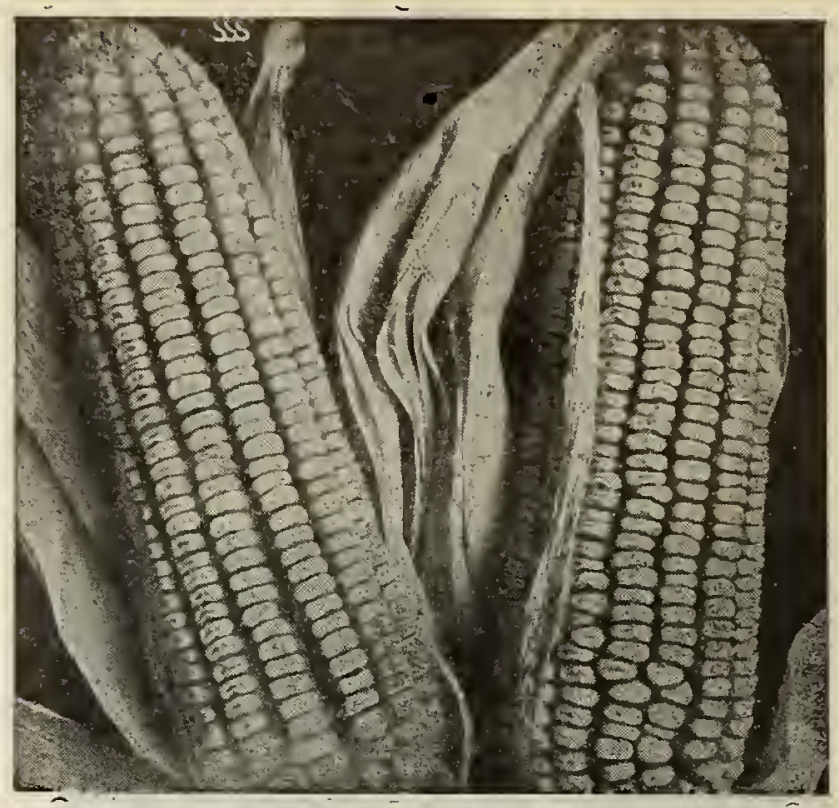

Wyatt's Improved Golden Dent.

Trucker's Favorite. For such markets as rank size and profit first, this variety is very profitable to grow for market as a Sugar Corn; it is a White Dent sort with 12-rowed, long, symmetrical, well-filled ears. Qt. 35 cts., 4 qts. $\$ 1.00$, pk. $\$ 1.65$. bu. $\$ 5.50,5$ bus. at $\$ 5.25$.

Hickory King. (100 days). It produces on good soil three or four average-sized ears to the stalk. The grain is large, broad and beautifully white, making the finest quality meal. The cob is of ten so small that a large sized grain will cover the end of it. By express or freight, qt. 25 cts., pk. $\$ 1.00$, bu. $\$ 3.50$; by mail, postpaid, pkt. 10 cts., qt. 40 cts.

Wyatt's North Carolina Two. Ear White. An extra-early vaWhite Dent riety that we have been improv-
ing on our own Wake County farms. Stalks produce two
and three ears of good size; the fodder is also abundant and of fine quality. $\mathrm{Pk} . \$ 1.00$, bu. $\$ 3.50$, not prepaid.

Mexican June Corn. This corn is planted very extensively during the months of May, June and July; stands the dry weather. It is largely used for roasting ears. Not prepaid, qt. 25 cts., 4 qts. 75 cts., pk. $\$ 1.25$, bu. $\$ 4.00$.

Eureka Ensilage Corn. The highest yielding silo filler. Qt. 25 cts., 4 qts. 75 cts., pk. $\$ 1.25$, bu. $\$ 3.25$, not prepaid.

Save Your Meat With
[[CHAMBER'S ANTI-SKIPPER COMPOUND]
If unobtainable at your dealer's we will send by
parcel post prepaid-
$50 \mathrm{ct}$. size, sufficient for 250 pounds; $\$ 1.00$ size,
for 500 pounds.

All styles of IBON AGI CUITIVATORS and FARROWS are carried in stock as well as a complete line of Steels and Repairs.
Rax (Rat Killer) .......\$.75

Rat Snap, 35 cts., 65 cts.... 1.25

Rat Paste, per tube $\ldots \ldots \ldots . .25$

Bernard's No. 25 Pruning

Shears

Bed Bug Destroyer........... 1.50

\section{FARII HEIPS}

McNair's Barnyard Protector.
pkg. $. \ldots \ldots \ldots \ldots \ldots \ldots \ldots \ldots \$ . .55$ Disston "ì. 250 Pruning Shears .............2.50 Sodium Fioride pkg. $35 \mathrm{c}$ and $60 c$ Chipman's Fly Killer, gallon, 1.50 [52] Disinfecto, 60 c per can-5
cans .............. $\$ 2.50$ Cow Spray -1 qt. $50 \mathrm{c}$ : $1 / 2 \mathrm{gal}$ $85 \mathrm{c}$; gallon ........... 1.40 Puppy Biscuits. pkgs. $25 \mathrm{c}$ and 500 Dog Biscuits, pkgs...25c and 500 


\section{SOJA, or SOY BEANS}

A Great Drought.Resisting Forage Crop, Producing Immense Quantities of Nutritious Feed, Besides Being an Excellent Soil Improver.

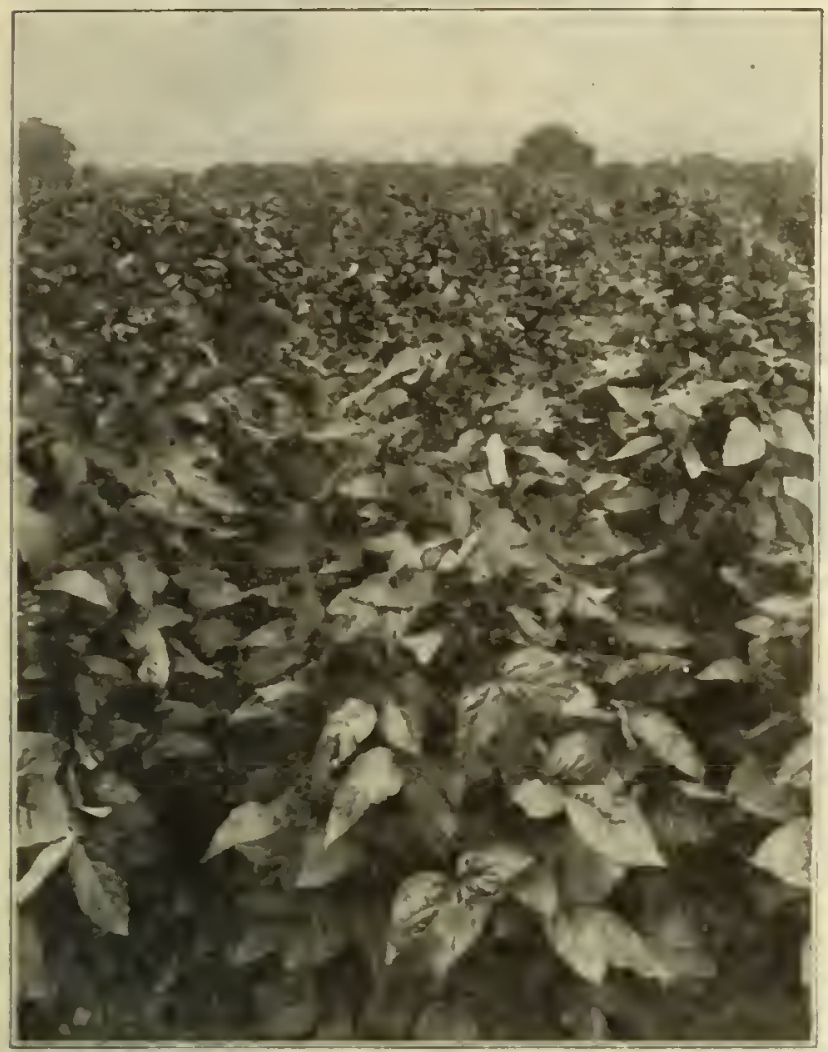

Mammoth Yellow Soy, or Soja Beans.

Very few varieties make a vinc, but are of upright growth, although if grown on rich soil there is a tendency to lodge. The Soy Bean produces a much larger crop of seed than the Cowpea, and this crop is easier to harvest.

The plant is generally upright. branched, and grows from $11 / 2$ to 4 feet tall, according to variety and weather conditions. The plants are covered with fine hairs. whereas the Cowpea is smooth and glossy. The pods are small and usually contain many beans. With so variable a plant, it is but natural that many varieties are offered.

If sowed in rows $21 / 2$ feet apart, it requires $1 / 2$ bushel of seed per acre; and if drilled in or broadcast, 11/, bushels per acre. Seed can be sown in May. Junc, or July, but does best if sown rather early and the seed should be covered lightly, not over a couple of inches.

Soy Bean prioes, Jan. 1, 1926: Pk. 81.00 , bu. $\$ 3.00$. Write for firm quotations when ready to place your order.

Mammoth Yellow. The largest-growing and most popular of Soja Beans for forage purposes. A little later in maturity than other kinds, but makes larger yields. both of forage and seed. Especially valuable for this section, and further south. Lb. 15 cts., (postpaid, lb. 23 cts.). Price fluctuates.

Tar Heel Black. Dark green foliage. Slightly earlicr than Mammoth Yellow. Heavy growth of vine, upright in habit, and a Soja Bean that is destined to become very popular. Lb. 15 cts., (postpaid, 1b. 23 ct8.).

Brown. Thls is one of the best varictles for forage and soil-improving purposes, maklng a quick and large growth of forage. Probably better adapted for sowing with cowpcas than any other klnds, on account of its maturing with the cowpea crop. Lo. $15 \mathrm{cts.}$ (postpald. 1b. 23 cto.).

Modium Soy, Wllson, Early Rlack, Haberlandt, Vlrzinia, and other varictics of Soy Beans. Prices on application.
Mung Beans. A wonderful new Bean. Good soil builder, also excellent for stock. $1 \mathrm{lb}, 35 \mathrm{cts} .4 \mathrm{lbs}$. $\$ 1.25$. Large lots. $25 \mathrm{cts}$. per lb.

Biloxi Soy Bean. A new lieavy yielding variety. Does not shatter seed. Lb. 35 cts., postpaid, pk. \$1.25, bu. $\$ 4.00$

Otootan. The best Soy Bean for hay. It produces an abundance of fine texture foliage. $1 / 2 \mathrm{pk} . \$ 1.00, \mathrm{pk}$. $\$ 1.95$. Write for quantity prices.

Laredo. A new varicty of high merit. IVell adapted to the Carolinas. $1 / 2 \mathrm{pk} . \$ 1.00 .1 \mathrm{pk} . \$ 1.95$.

\section{NORTH \\ CAROLINA-GROWN COTTON SEED}

One to 11/3:bushels of seed is required for an acre.

The cultivation of Cotton varies considerably, of course. according to the locality and soil, but in general the ground should be prepared by thorough plowing and harrowing, with rows 40 to 50 inches apart. 5 feet being given where the land is unusually rich. Seeding is best done with the Cotton planter, and the young plants should be thinned to about 12 or 18 inches in the rows; if the ground is very rich, two plants may be left in a hill, but otlierwise only onc.

Perry's Early Prolific. (Medium boll). A good early varicty. Pk. 75 cts., bul. $\$ 2.50$.

King's. (Medium boll), It is one of the carliest kinds, and is invaluable for sections where the growing season is short. Pk. 75 cts., bu. $\$ 2.50$. Write for prices on larger quantities.

Ideal. (Medium boll), It is of rank growth and resists drouth better than most kinds. Pk. 75 cts., bu. $\$ 2.50$. Write for special prices on larger quantities.

Cleveland Big Boll. (Special Wake County Strain), This is the variety from which the famous Wannamaker Cleveland was developed. It lias bigger bolls tlian IVannamaker, and longer staple, about 1 1-16 incli full, and for that reason is better liked in some sections. Price, single busliels. $\$ 2.50$.

Write for prices on Cotton Secd. We have only listed a few varictics of cotton, but we can furnish most varieties. Write for prices.

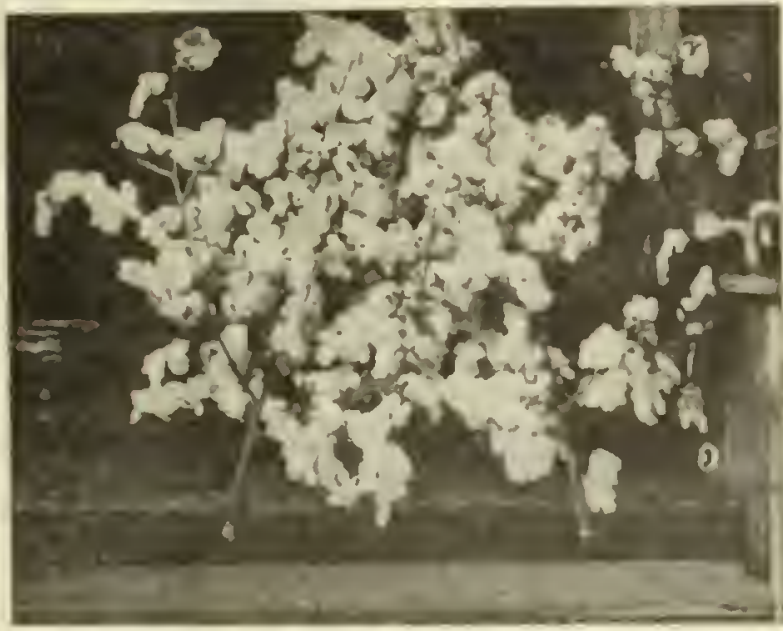

Cloveland B18 Boll Cotton.

THE PUTNAM BROODER

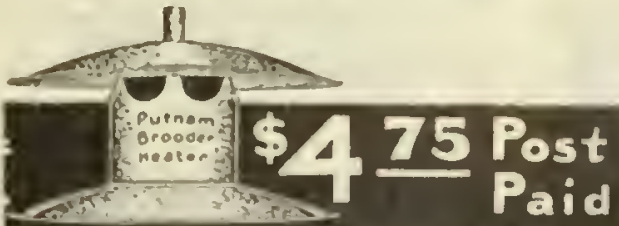

Burns 10 days,without attention 


\section{INSECTICIDES AND FUNGICIDES}

PARCII POST. Only those insecticides marked can be shipped through the malls. Articles so marked will be shipped provided sufficient postage is included with your order.

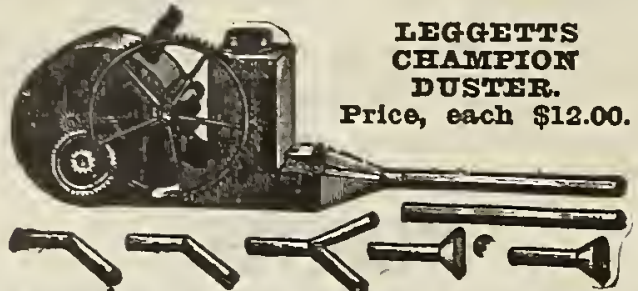

Arsenate of Lead. Paste. A poison remedy for leafeating insects. Dilute $1 \mathrm{oz}$. to 1 gal. of water. $5 \mathrm{lbs}$. $\$ 1.25,10$ lbs. $\$ 2.25,25$ lbs. $\$ 4.00$.

Arsenate of Lead. Powder. Superior to paste in that it does not deteriorate from standing. Use 1 to $11 / 2$ lbs. to 50 gals. of water. $1 / 2 \mathrm{lb} .30 \mathrm{cts}, 1 \mathrm{lb} .50 \mathrm{cts}$., $5 \mathrm{lbs}$. $\$ 2.00,10$ lbs. $\$ 3.75,25$ lbs. $\$ 6.25$.

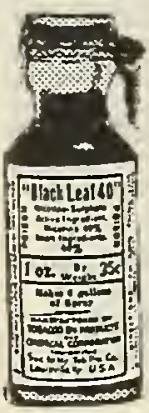

Black Leaf 40. A concentrated nicotine solution for aphis, thrip, and red spider. Dilute $1 \mathrm{oz}$. to from 3 to 6 gals. of water. 1 oz. 35 cts., $1 / 2$ lb. $\$ 1.25,2$ lbs. $\$ 3.50,10$ lbs. $\$ 13.75$.

Bordeaux Mixture. Powder. Can be used dry or as a spray. When used as a spray 6 lbs. to 50 gals. of water will make standard 3-3-50 mixture. $1 \mathrm{lb}$. 50 cts., 5 lbs. $\$ 1.50$, 10 lbs. $\$ 2.75$. Cannot be mailed.

Bordeaux Arsenate of Lead. Powder. Use $7 \mathrm{lbs}$ to 50 gals. of water. $1 \mathrm{lb}, 50 \mathrm{cts}, 5$ lbs. $\$ 2.00,10$ lbs. $\$ 3.75,25$ lbs. $\$ 8.00$.

Sulfocide. Best spray for use during the growing season. $1 \mathrm{pt}$. 50c; $1 \mathrm{qt}$. $75 \mathrm{c} ; 1$ gal. $\$ 2.25$.

Scalecide. A spray for scale. Dilute 1 gal to 15 gals. of water. 1 qt. $75 \mathrm{c} .1$ gal. $\$ 1.75,5$ gals. $\$ 6.25,10$ gals. $\$ 10.60$.

*SIug Shot. One of the most known reme3ies for cabbage and currant worms. Apply as bought. $1 \mathrm{lb} .25$ cts, 5 lbs. $60 \mathrm{cts}, 25$ lbs. $\$ 2.75,100$ ibs. $\$ 11.00$

*Fish Oil Soap. A remedy for scale and aphis. 1 lb. -25 cts.

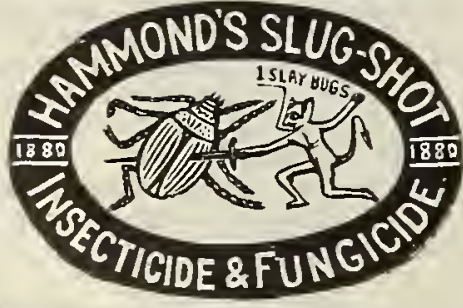
5 lbs. $\$ 1.00,25$ lbs. $\$ 4.00$.

*Sulphur. Powdered. For mildew. $1 \mathrm{lb}, 15 \mathrm{cts}, 5 \mathrm{lbs}$. $60 \mathrm{cts}, 10$ lbs. $\$ 1.10,100$ lbs. $\$ 8.00$.

*Tobacco Dust. Coarse and Fine. Used for fumigating and for dusting plants affected with aphis. $1 \mathrm{lb} .10 \mathrm{cts}$, 5 lbs. 40 cts., 25 lbs. $\$ 1.50,100$ lbs. $\$ 5.00$.

*Tobacco Stems. Used for fumigating and as a fertilizer. Bale, about 100 lbs. $\$ 3.50$.

Paris Green. (For leaf-eating insects.) It is a strong poison and should be used with care. Mix 1 pound of Paris Green to 50 pounds of plaster, or with water to 150 gallons. On vines and tender vegetables use a larger proportion of plaster or water. $1 / 4 \mathrm{lb} .20 \mathrm{cts}, 1 / 2 \mathrm{lb} .35$ cts, lb. $60 \mathrm{cts}, 5 \mathrm{lbs}, \$ 2.50,10 \mathrm{lbs}$., $\$ 4.50$.

Lime Sulphur Solution. The standard remedy for scale and for certain fungus. Use 1 part to 9 parts of water. 1 qt. 50 cts, 1 gal. $\$ 1.00,5$ gals. $\$ 4.25,10$ gals. $\$ 7.00,30$ gal. bbl. at 40 cts. per gal., 50 gal. bbl. at 30 cts. per gal., cans and barrels extra at value.

Cans with Wooden Jackets. For oil, etc. 1 gal. 60 cts. 2 gals. 75 cts., 3 gals. $\$ 1.00,5$ gals. $\$ 1.25$.

*Axfixo. A good nicotine dust. $40 \mathrm{c}$ and $\$ 1.50$ cans.

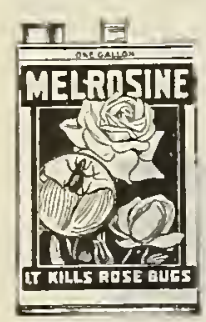

*Melrosine. The General Contact Insecticide that Kills Rosebugs and other insects. Used with any good spray-pump, diluted with from 20 to 25 parts of water. Guaranteed effective when used according to directions on can. Gal. $\$ 6.00$, halfgal. $\$ 3.25$, qt. $\$ 1.75$, pint $\$ 1.00$, trial size $50 \mathrm{cts}$. By mail or express at customer's expense. Or trial size, sufficient to make one gallon when diluted, and care for several plants for the season, postpaid for $60 \mathrm{cts}$.

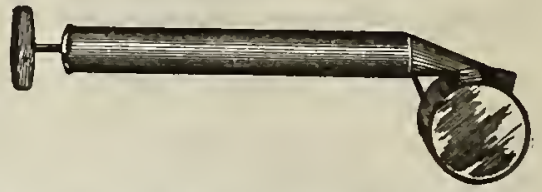

Spray Atomizers, 50 cts. Postage 10 cts. extra.

Lime Sulphur. Powder. Apply 12 to $15 \mathrm{lbs}$. in 50 gals. of water. $1 \mathrm{lb} .35$ cts., 5 lbs. $\$ 1.50,10$ lbs. $\$ 2.50,25 \mathrm{lbs}$. $\$ 5.00,50$ lbs. $\$ 9.00,100$ lbs. $\$ 16.00$.

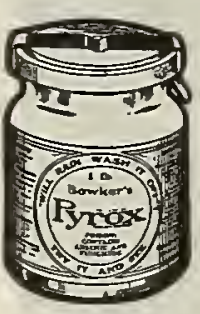

Pyrox. (Bordeaux Arsenate of Lead. Paste.) A combination of Bordeaux Mixture and Arsenate of Lead, forming thereby a remedy for fungus and leaf-eating insects. Use $1 \mathrm{lb}$. to from 5 to 10 gals. of water. $1 \mathrm{lb} .50 \mathrm{cts}$. 5 lbs. $\$ 1.75,10$ lbs. $\$ 3.00,25$ lbs. $\$ 6.25$. 50 lbs. $\$ 11.50,100$ lbs. $\$ 18.00$.

Copper Sulphate (Blue Stone, or Blue Vitriol). Used for early spraying and in making Bordeaux Mixture. Will keep indefinitely. Special prices quoted on large quantities. By express, lb. $20 \mathrm{cts}, 10 \mathrm{lb}$. lots at $18 \mathrm{cts}$. per lb., $50 \mathrm{lb}$ lots. at 15 cts. per lb.

Calcium, Arsenate. (Dry). For dusting and spraying. A new arsenical poison for chewing insects, especially potato beetles. Harmless to foliage, not easily washed off. Lb. 40 cts, 5 lbs. $\$ 1.25,10$ lbs. $\$ 2.00$, Write for prices in $100 \mathrm{lb}$. lots.

Bug Death. Kills potato, squash and cucumber bugs, tomato, currant and gooseberry worms, and all leafeating pests. May be applied dry. in water or in Bordeaux Mixture. By express or freight, $1 \mathrm{~b} .25 \mathrm{cts}$. 3 lb. pkg. 50 cts., $5 \mathrm{lb}$. pkg. 80 cts. $121 / 2$ lb. pkg. $\$ 1.75$. Use $121 / 2$ to 25 lbs. per application to the acre. Write for circulars.

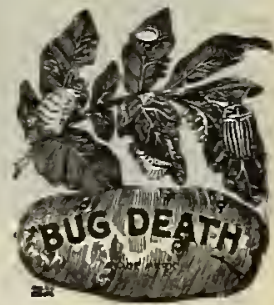

B. T. S. One of the best dormant sprays. Prices same as Dry Lime Sulphur.

Bee Brand Insect Powder. 25 cts. can.

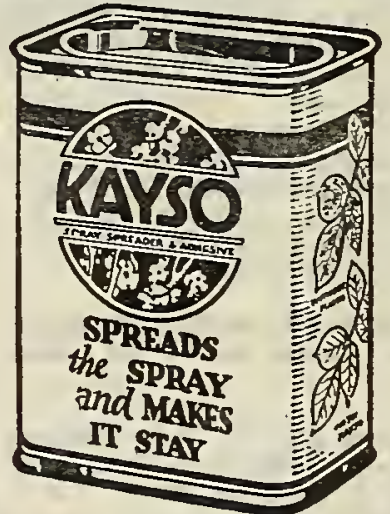

Preventol. The all-around disinfectant. 1 pt. 75 cts. 1 qt. $\$ 1.25,1 / 2$ gal. $\$ 2.00$.

Peach Mix. The best sum. mer spray for Peaches, Plums, etc. $1 \mathrm{lb} .35 \mathrm{cts}$. 5 lbs. $\$ 1.50,10$ lbs. $\$ 2.50$ 100 lbs. $\$ 16.00$.

*Kayso. Spreads the spray. 1 lb. to 100 gallons or 2 heaping tablespoons to each 10 gallons. Packed in 8 oz. pkgs. 25 cts., 2 lbs. 60 cts., 10 lbs. $\$ 2.75,50$ lbs. at 26 cts., and $100 \mathrm{lb}$. pkgs. at 25 cts.

Black Flag (Liquid). 30 cts., 50 cts. and $\$ 1.00$. Powder: 50 cts. and $\$ 1.00$.

Grape Dust. Best remedy for mildew. 35 cts. pkg.

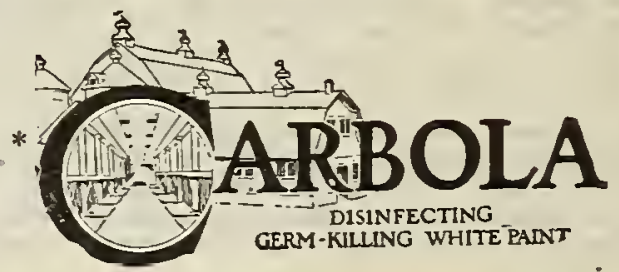

Particularly good for use in stables, cow barns, chicken coops, dairies, hog pens, creameries, cellars, factories and outbu:ildings. Prices: 5 lbs. 85 cts., 10 lbs. (makes 10 gallons.) for $\$ 1.50,50$ lbs. $\$ 6.00,300 \mathrm{lbs}$. at $10 \mathrm{cts}$ per lb. 


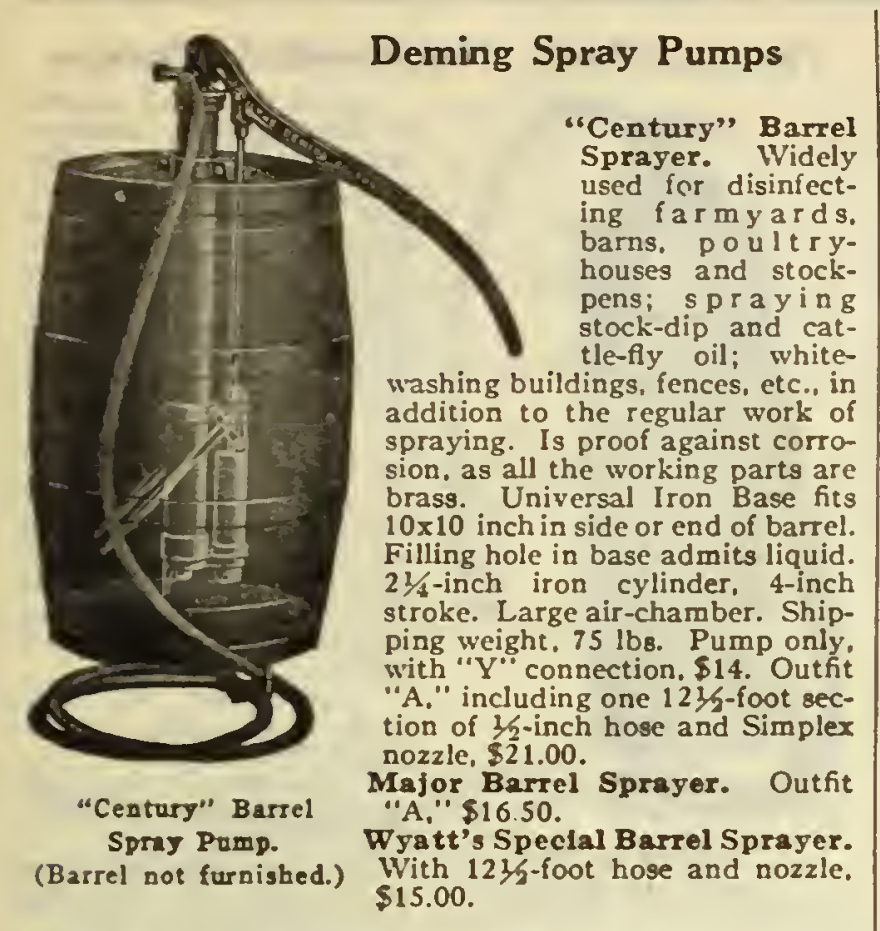

Bellows Dust Gun. $\$ 1.50$ each.

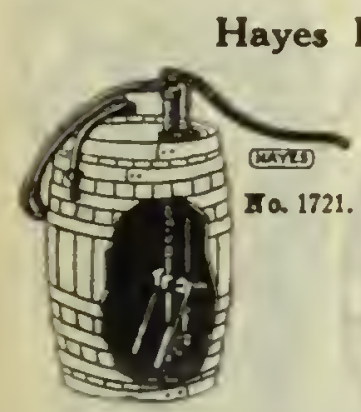

No. 1821 for closed barrel, with $123 / 5 \mathrm{ft}$. hose and nozzle. $\$ 17.50$. No. 1721 for open barrel, with $12 \mathrm{l} / \mathrm{ft}$. hose and nozzle. $\$ 16.00$ With $25 \mathrm{ft}$. spray hose. nozzle and fittings, add price $\$ 6.00$.

With $8 \mathrm{ft}$. Steel Extension, add price $\$ 1.00$.

Shipping weight, about $38 \mathrm{lbs}$.

(Barrels not furnlshed)

\section{Hayes Wheelbarrow Sprayers}

For spray solutions, disinfectant 8 or whitewash. With extra long handle and large air chamber. develops 150 to 200 Ibs. pressure with minimum of effort. Made of best materials, all working parts of brass or bronze. Cart is strong. all steel and cross braced. Tank holds $121 / 2$ gallons.

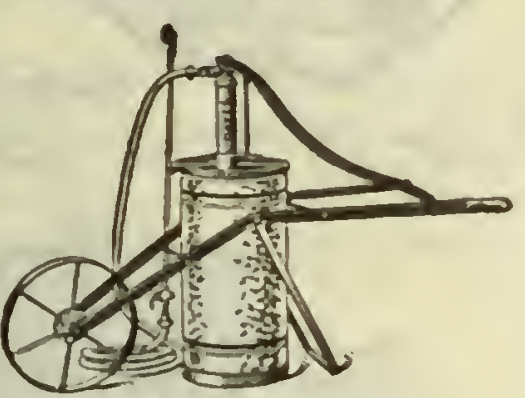

ז0. $1721 \mathrm{~F}$.
Fully equipped with hose, nozzle, fittings, steel extension. etc. No. $1721 \mathrm{~F} \$ 24.00$.

With 25 ft. hose, add price \$2.20.

Shipping weight 80 lbs.

Myer's No. 296 Galvanlzed Compressed Alr Sprayer. $\$ 7.00$.

No. 297. Brass Compressed Mr Sprayer $\$ 10.00$.

Gardener's Cholce Cart Sprayer. Shipping weight. 120 lbs. Price \$15.50.

Perfect Suecess Bucket Spray Pumps. Price $\$ 7.50$ Auto Spray Bucket Spray Pump. No. 6. $\$ 6.00$.

Myers Portable or Wheelbarrow Sprayer. No. R336B. $\$ 26.00$.
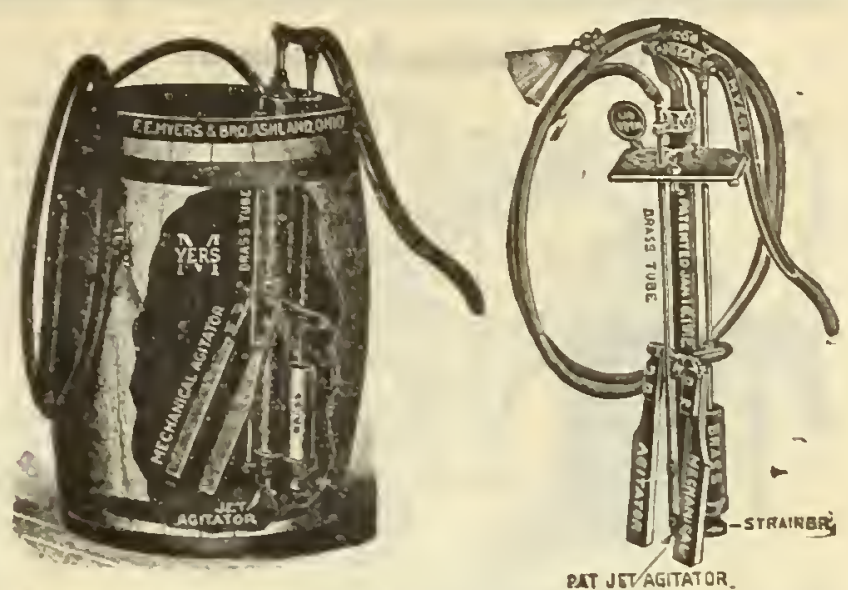

Myers No. R305B Orchard Pump, with $15 \mathrm{ft}$ of hose and nozzle. Price, without barrel, \$15.00.

Myers No. R318B Orehard Pump; extra heavy barrel sprayer; $15 \mathrm{ft}$. of hose and nozzle. Price, without barrel, $\$ 16.00$.

\section{Spray Pumps}

No. R 32t-Myers Cog Gear Bucket Pump...... . \$6.50 No. 323-Peerless Brass Bucket Sprayer........ 4.00 No. 3271, - Little Giant Bucket Sprayer..

\section{Hayes Platform Duplex Sprayers}

Working parts of brass or bronze. Completely equipped with 50 gal. barrel, filling hopper, agitator. $300 \mathrm{lb}$. gauge. $1215 \mathrm{ft}$. spray hose, fittings, 10 ft. extension rod. nozzle, etc. No. 1217, price $\$ 75.00$ : other ty pes $\$ 63.00$ up. Length 6 ft., shipping wt., 250 ibs.

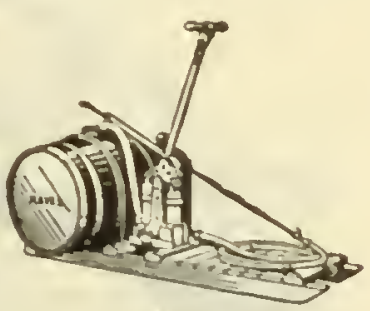

พ0. 1217

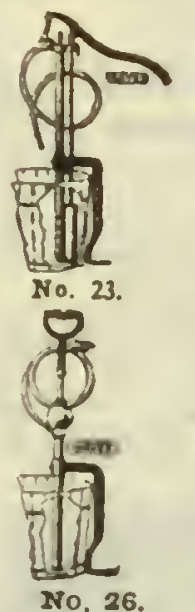

\section{Hayes Bucket Sprayers}

Strong, simple and unusually effective bucket spravers. Made of seamless brass tubing with bronze ball valves that resist corrosion. Each sprayer fully equipped with liose, dises for fine or coarse spray and extra solid stream cap.

Especially adapted for home and garden use - also for disinfectants and whitewashing where an effective sprayer and small quantities are desired.

No. 211 Single acting........... $\$ 5,00$

No. 231 Single acting............ 900

No. 251 Double acting........... 7.50

No. 261 Double acting........... 9.00

With Hayes Bucket Clamp, add 75 cts.

With $8 \mathrm{ft}$. steel extension, add $\$ 1.00$.

No, 26

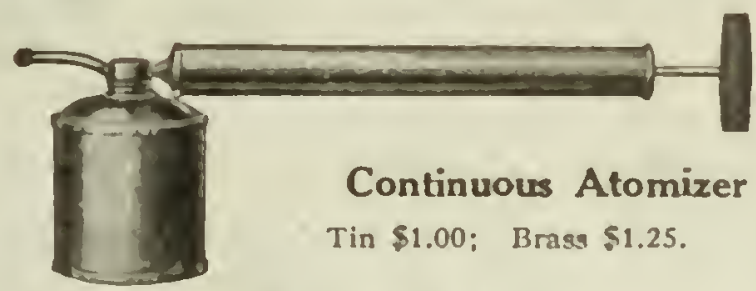

\section{Calispray Dust Gun}

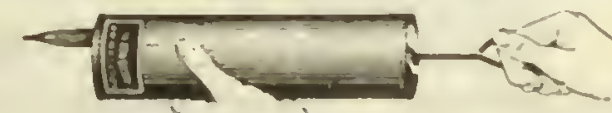

Double-acting. and applies all dry powdered insecticides in a smoke-like clond that reaches all parts of the plant. By mail, postpairl. \$1.50; by express, \$1.40. Other styles. $\$ 2.00, \$ 2.50, \$ 5.00, \$ 10.00$. 


\section{Myers Knapsack Sprayers}

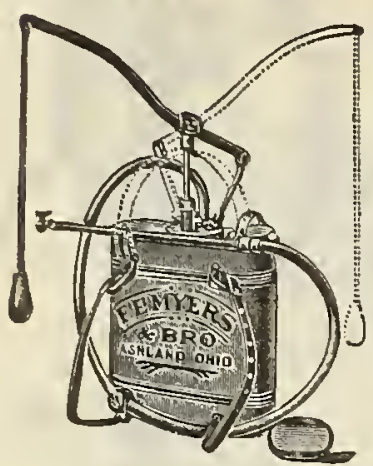

Galvanized tank with removable lid and strainer; the pump has solid brass bucket with large air chamber, ball valves, solid plunger and agitator; the handle lever can be shifted from right to left shoulder; this pump can be operated equally as well supported on the back as when on the ground; knapsack with 5 feet of $1 / 2$ inch hose, pipe extension, Bordeaux spray nozzle.

No. 330 Capacity 5 gallons; height of tank $131 / 2$ inches; width 15 inches; 6 inches thick, each $\$ 12.50$.

No. 331-Copper tank $\$ 18.00$ each.

One in a wood box; weight each 22 lbs.

\section{Savage \\ Duster}

Most powerful hand duster made $\$ 20.00$, prepaid.

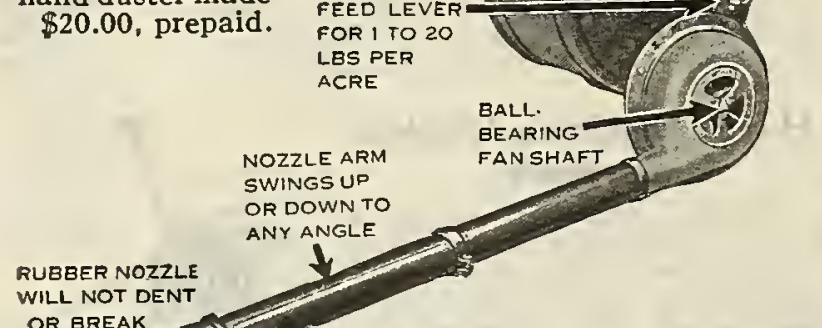
and Hayes Spray Pumps. Also Auto Spray Pumps.

Let us quote on your Power Sprayer, Spray Hose, etc.

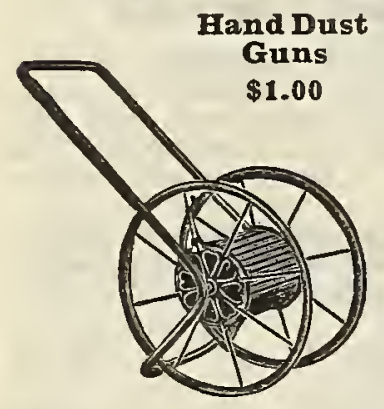

\section{Bamboo Rods}

Brass Lined

$8 \mathrm{ft} \ldots \ldots \ldots \ldots \ldots \ldots \$ 4.50$ $10 \mathrm{ft} . \ldots \ldots \ldots \ldots \ldots \ldots \ldots, 4.75$

$12 \mathrm{ft} . \ldots \ldots \ldots \ldots \ldots .5 .00$

Other rods, let us know your requirements.

$8 \mathrm{ft}$. spray pipe extension $\$ 2.55$ $4 \mathrm{ft}$. extension........ 1.35

Iron Hose Reels.......\$3.75 American Hose Reels.. . 2.50

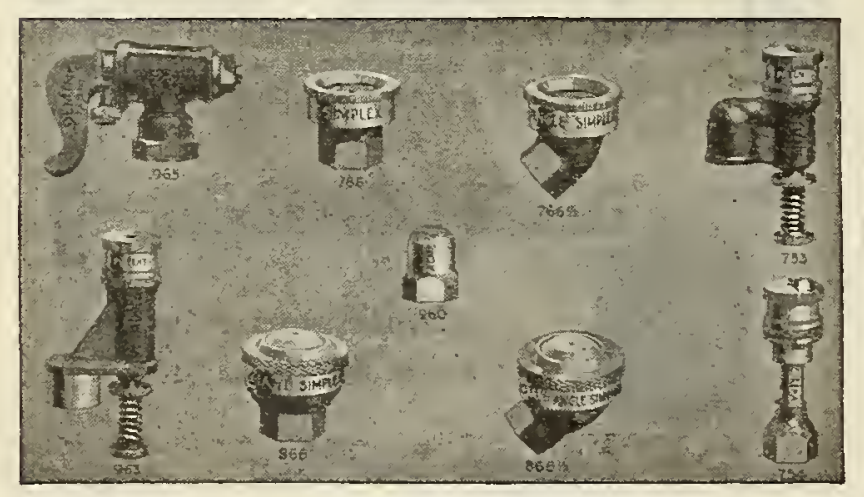

\section{Price List of Nozzles}

\section{Auto-Spray No. 3-D}

Galvanized tank. Capacity, 12 gallons. With truck, 20-in. wheels $\$ 25$.

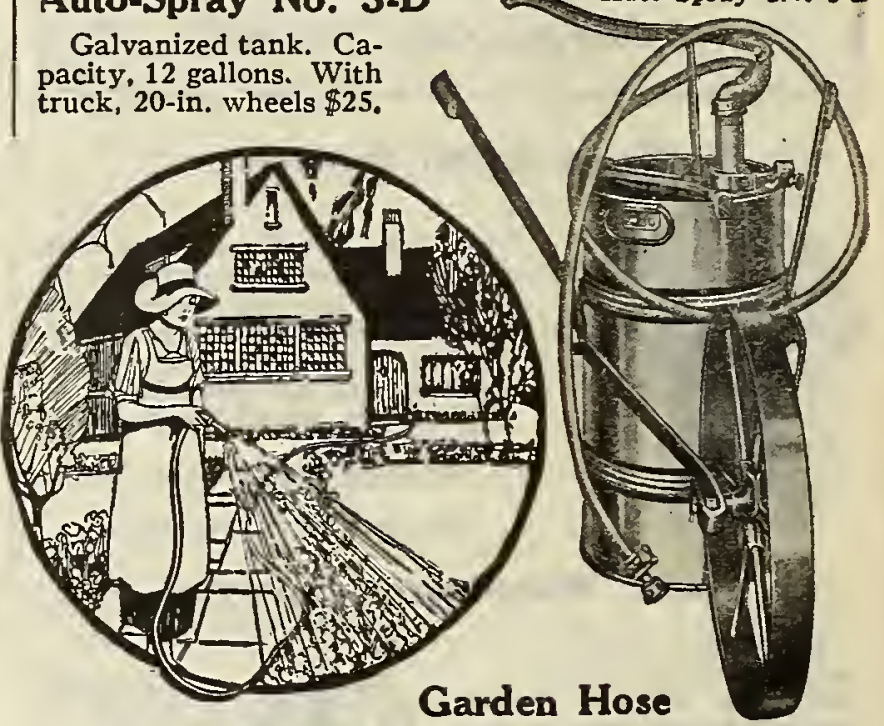

25 and $50-\mathrm{ft}$. lengths with couplings, $121 / 2 \mathrm{cts}$., $15 \mathrm{cts}$ $20 \mathrm{cts}$. and $25 \mathrm{cts}$. per foot. depending on quality.

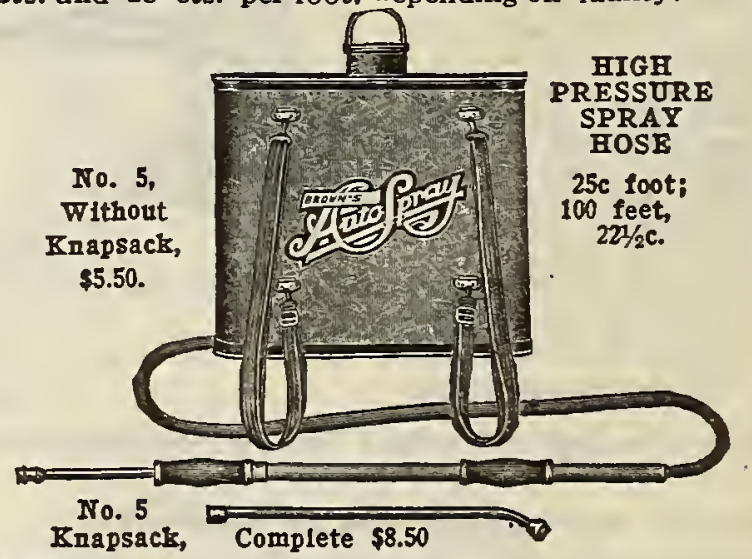

Figure 965. Bordeaux. May be adjusted to throw fine or coarse spray or solid stream. Best for white-washing, $\$ 1.25$.

Figure 963. Vermorel. With caps for fine or coarse spray. Spring disgorger, $\$ 1.00$.

Figure 7661/2. Angle Simplex. Has two removable steel discs for coarse or fine spraying, price, $80 \mathrm{cts}$.

The Auto-Spray Compressed-Air Sprayer

For applying all insecticides, fungicides, disinfectants, cattle-fly oil, whitewash and cold-water paint. The Auto-Spray is the strongest and most simple in its working parts of any Two pumpings of about 15 strokes on the plunger will discharge the contents under high and constant pressure. After pumping, the operator has nothing to do but direct the spray. It is regularly equipped with a carrying strap, 2 feet of $1 / 2$ inch hose, fine spray nozzle, solid-stream cap and shut off as selected and at pricess below.

"Auto-Spray" No. 1 B, brass tank, with "AutoPop," \$9.00.

Auto-Spray" No, 1 D, galvanized tank with "AutoPop," \$7.00.

Extension pipe, $2 \mathrm{ft}$. long solid brass, 70c. Gal.60c.

'Auto-Spray No. 3-D

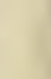




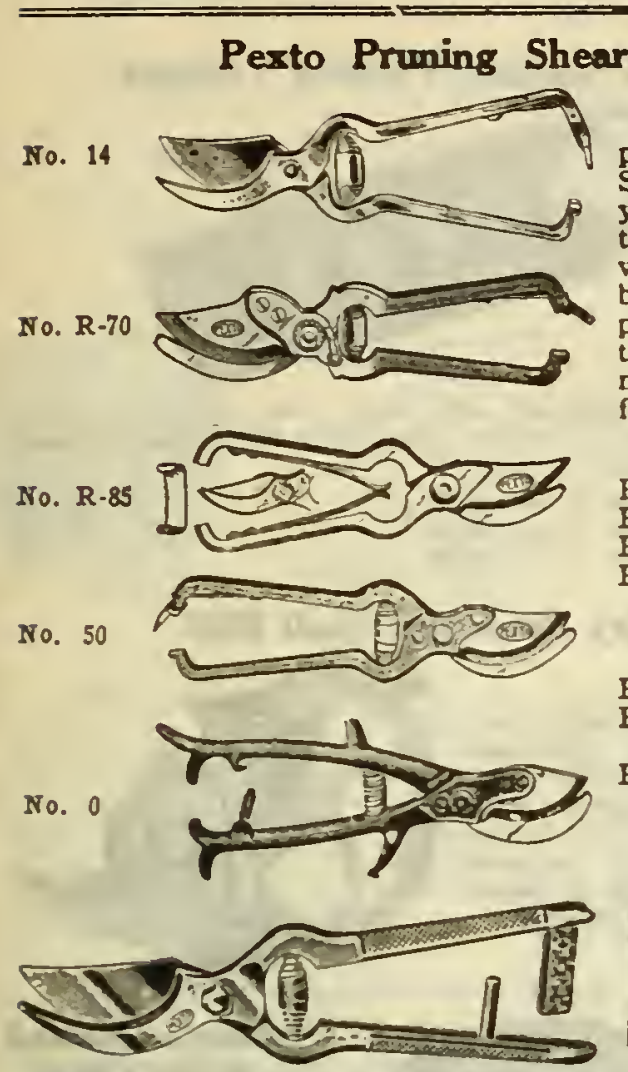

No. 300 Pexto French Peach Shear.

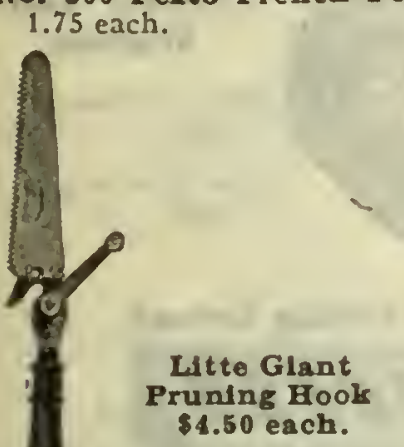

\section{Standard Cyphers Incubators}

These are machines that for fifteen years and more have been recognized as the standard hatchers of the world. They are used by more Government experiment statlons, on more large, practical poultry plants, on more successful duck and egg farms, and by a larger number of the foremost poultry breeders than all other makes combined. No. 0. 70-egg size. $\$ 33.00$ No. 2. 244-egg size. $\$ 56.00$ No. 1. 144-egg size.. 42.00 No. 3. 390-egg size. 69.00

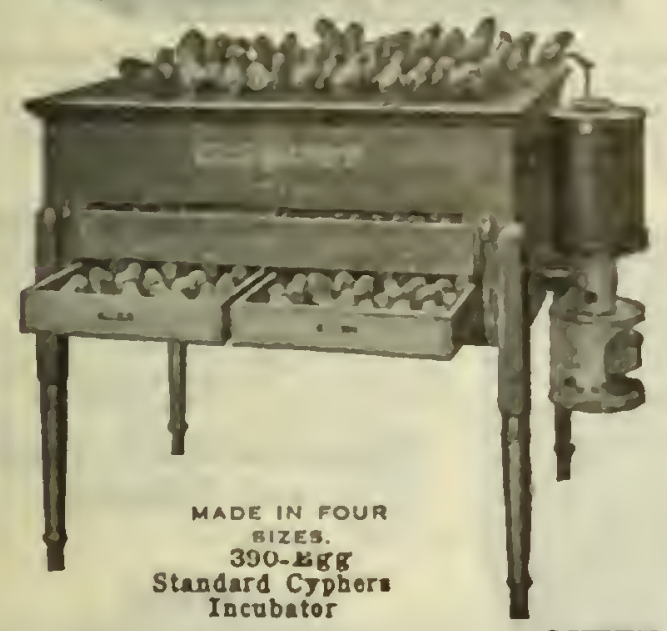

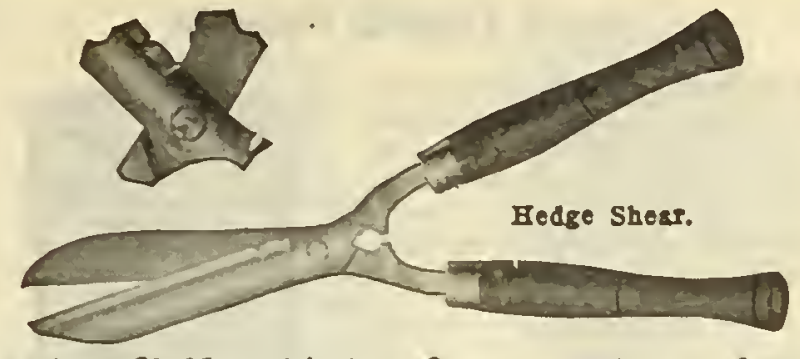

8 inch...\$2.25 9 inch...\$2.50 10 inch....\$2.75

Champlon Tree Euler.

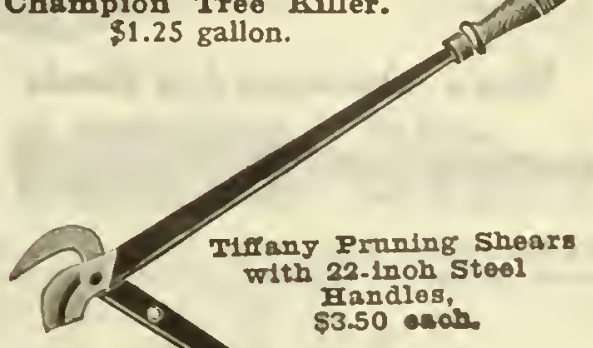

Lime Sulphur Solution. 50 gal. barrel. $\$ 18.00$ F. O. B. Raleigh. Barrel included.

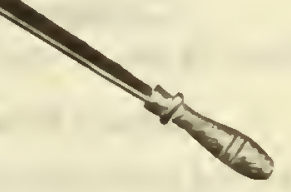

Pruning Shears and Saws

16-inch Pruning Saw............\$1.75

18-inch Prunlng Saw............. 1.85

20-inch Pruning Saw............ 2.00

Rhodes 36-inch D. C. W. H. Pruners... 5.00 Rhodes 30-inch D. C. W. H. Pruners... 5.00 Rhodes D. C. Pole Pruner.......... 7.50 Rhodes Pole Paragon Pruning Saw.... 4.00

QUEEN ST YLE K INCUBATOR

No. 7-Qucen Indoor Brooder, 125 chicks......\$19.50 No. 22-Incubator. Capacity 220 cgks........\$36.75 No. 11 -Qucen Outdonr Brooder. 165 chicks..... 34.50 No.21-Incubator. Capacity 130 eggs........ 27.50 No. 20-Incubator. Capacity 70 cega......... 16.50 No. 5-Inrubator. Capacity 400 eggs. 


\section{Moe's Top-Fill Fountain}

Provides pure, fresh water at all times. The double wall construction retards freezing, and keeps water cool in summer. Fills from the top, easily cleaned, and feeds automatically.

Capacity Each.

No. 11 Gallon.......\$1.75

No. 2 Gallon...... 2.50

No. 44 Gallon...... 3.00

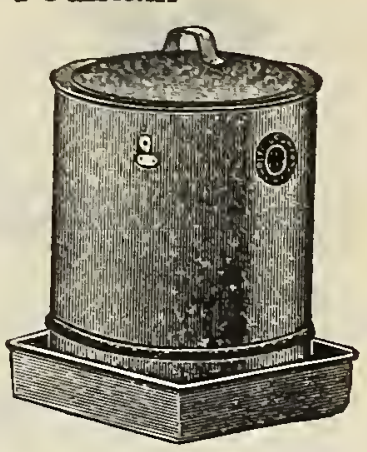

Moe's Aluminum Leg Bands

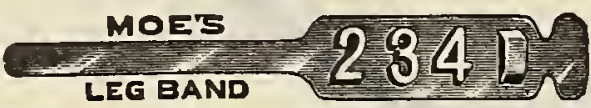

No. 130-Aluminum, with extra large raised numbers. Easy to read, adjustable for any size fowl. Quickly applied. Package of......... $12 \quad 25 \quad 50 \quad 100 \quad 500 \quad 1000$ $\begin{array}{llllll}\text { Price.............. } \$ 0.15 & .25 & .45 & .75 & 3.50 & 6.00\end{array}$

\section{Celluloid Leg Bands}

All colors, 15 cts. per dozen; 75 cts. per 100.

\section{Moe's Poultry Punch}

Makes a clean perforation and does not bruise the foot.

No. 38 Moe's Punch, each..\$0.25

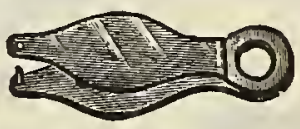

\section{Thermometers}

Tyco Incubator. Adjustable, can be used in any machine. Price $\$ 1.00$ (mailing weight, 4 ozs.).

Brooder. Price $75 \mathrm{cts}$. (mailing weight, 3 ozs.).

Tycos Hygrometer. $\$ 1.75$. (Postage 10 cts. extra).

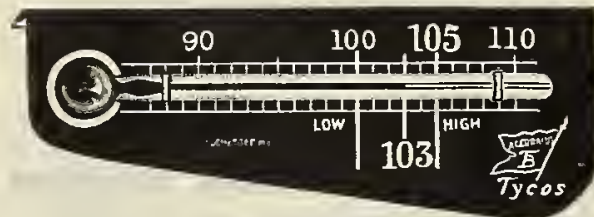

Moe's Grit and Shell Boxes

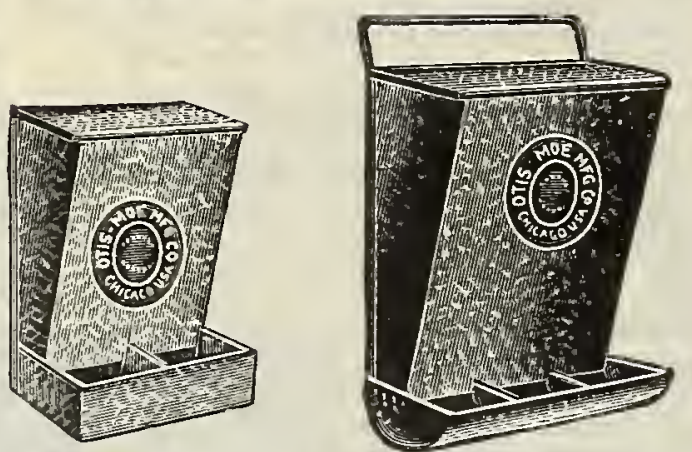

A special feed hopper and grit box for baby chicks. No. 45 Two Compartments, each...........\$0.50

Economical and practical for feeding grit, shells etc.

No. 9 Three Compartment, each............\$1.00

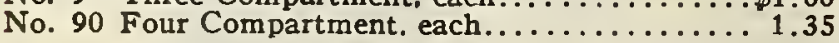

We can furnish Oat Sprouters, Vegetable and Hay Racks for Rabbits and many other supplies. Write for prices.

Philadelphia Caponizing Set. In plain box, $\$ 2.50$. In lined box, price, $\$ 2.75$.

\section{Moe's Sanitary Feeding Troughs}

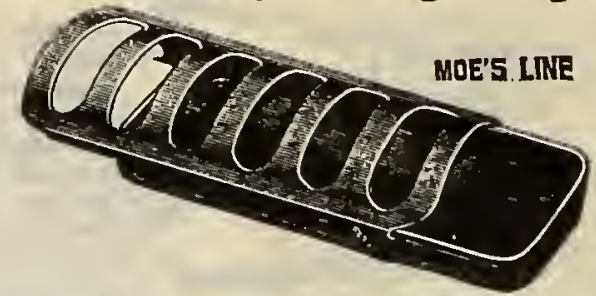

Accurately stamped with dies. No sharp or rough edges to injure the chicks. Top slides off, so pan is easily filled and cleaned.

No. 21 Length 12 in., each.............\$0.45

No. 22 Length 18 in., each.......................

No. 23 Length 24 in., each................ .90

\section{Dry Bone and Shell Mill}

For grinding dry bones, oyster shells, charcoal, and coarse grain like corn, etc. The hopper is 4 inches wide and $41 / 2$ inches long. with a balance wheel 20 inches in diameter. Price $\$ 6.00$ each.
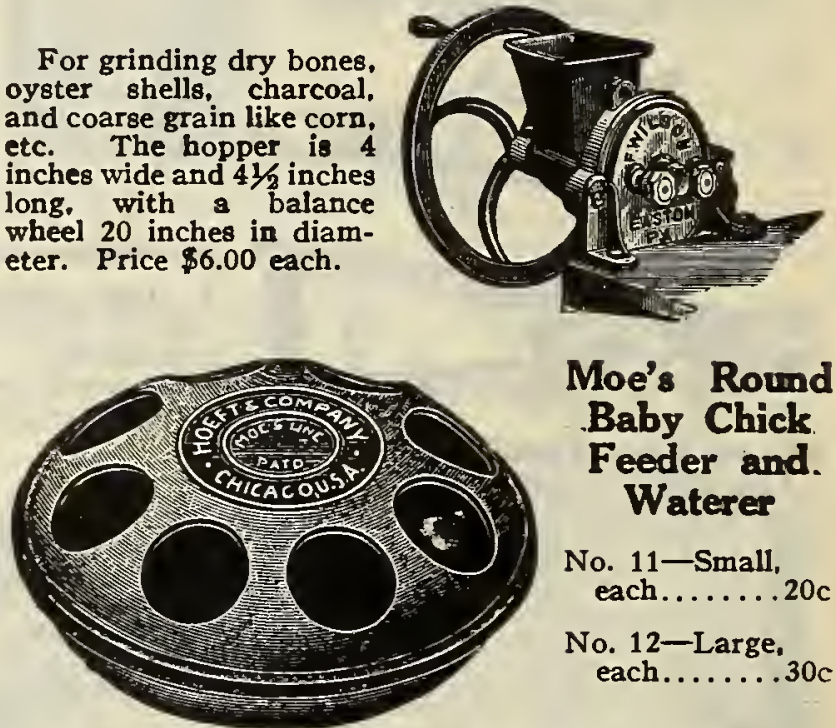

Moe's Round Baby Chick Feeder and. Waterer

No. 11-Small, each......20c

No. 12-Large, each.......30c

\section{Moe's Single Feeding Trough}

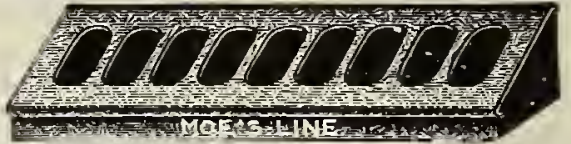

No. 55-Length 12 inches, each.............40c No. 56-Length 18 inches, each $\ldots \ldots \ldots \ldots \ldots \ldots .50 \mathrm{c}$ No. 57 -Length 24 inches, each..................

\section{Moe's Double Feeding Trough}

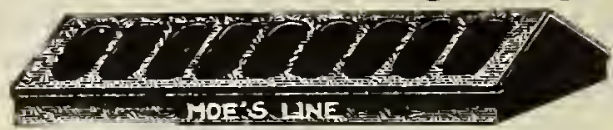

Double trough, with sliding top, easily filled and cleaned. Accurately stamped with dies. No rough edges.

No. 58-Length 12 inches, each................50 No. 59-Length 18 inches, each..............65c

No. 60 -Length 24 inches, each................

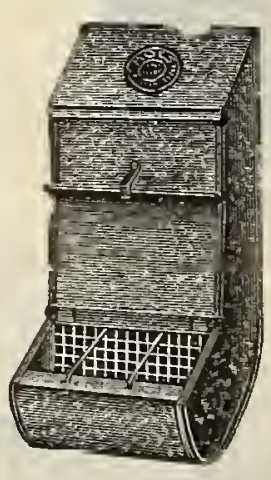

Moe's Dry Mash Hopper

Manufactured of heavy galvanized iron in three sizes.

No. $35-81 / 2$-in. wide, each....\$1.60

No. $36-12$ in. wide, each..... 2.00

No. $13-18$ in. wide, each...... 2.40

No. 37-24 in. wide, each..... 2.80

Magazine Chick Feeder and Waterer

No. 18. Each............75 cts.

\section{Wicks}

For Incubator and Brooder Lamps. 10 cts. each. Please give width wanted. 


\section{Dunham Water-Weight Lawn Rollers}

All Dunham Rollers are painted green on body and ends with red handles, and always bear the name Dunham. Rollers weigh 50 per cent more when filled with sand. Water is more convenient.

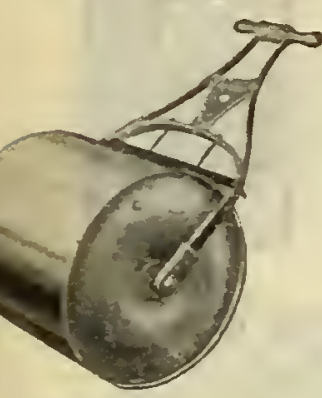
$\Rightarrow \quad$ With Roller Bearings $\begin{array}{lrrr}\text { Nos............ } & 5 & 7 & 9 \\ \text { Diam., inches. } & 18 & 24 & 24 \\ \text { Length, inches } & 24 & 24 & 32\end{array}$ IVeight, empty 85 lbs. $110 \mathrm{lbs} .130 \mathrm{lbs}$. Filled with water.... 265 lbs, 420 lbs. 565 lbs. Each........\$20.00\$23.00\$26.00 With Plain Bearings

$\begin{array}{lr}\text { Nos.................. } & 2 \\ \text { Diam. inches..... } & 4 \\ \end{array}$ Length, inches........ $24 \quad 24$ Weight, empty....6 68lbs. 821bs. Filled with water.... 175 lbs. 265 lbs. Each........... \$13.50\$16.00

\section{Moe's Star Fountain}

Made of a single piece of heavy metal. Suitable for feed as well as water. Little chicks can not drown. Fits any Mason jar in 1 Pint, 1 Quart. and 2 Quart sizes. No. 32 (Glass jar not included) Each, 20 cts., dozen, \$2.00.

\section{Moe's Never Fail Trap Nest}

As the name implies, it never fails. Every nest set up and ready for use when shipped. Manufactured in $t$ wo sizes No, 33, $12 \times 12 \times 12$ in., complete, each..........\$1.65 No. 34, for larger fowls, $12 \times 12 \times 141 / 2$ in., complete,

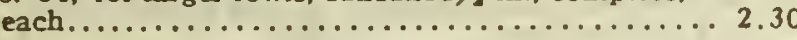

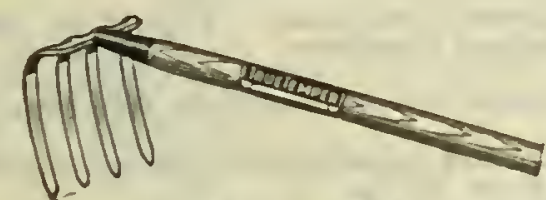

\section{Potato Hooks}

For potatoes, manure, etc. Flat Itines.

4 Prong, each.......\$1.00 5 Prong, each....\$1;25

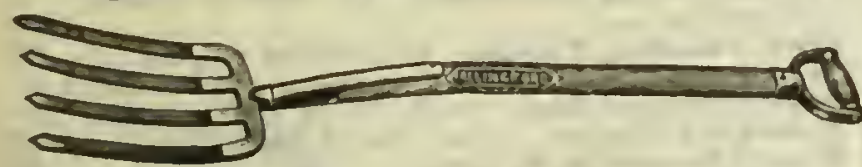

Spading Forks, each..............\$1.50

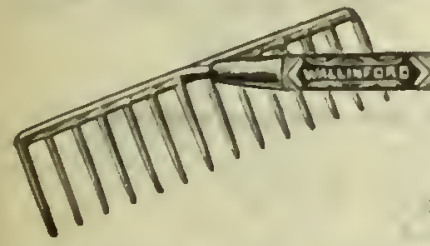

Lawn Edgers. Half. moon shape. $\$ 1.50$ each.

Steel Rakes ........... 75 cts., \$1.00, \$1.25 Wire Lawn Rakes. each................. 1.25 Wooden Rakes. each................... 1.50

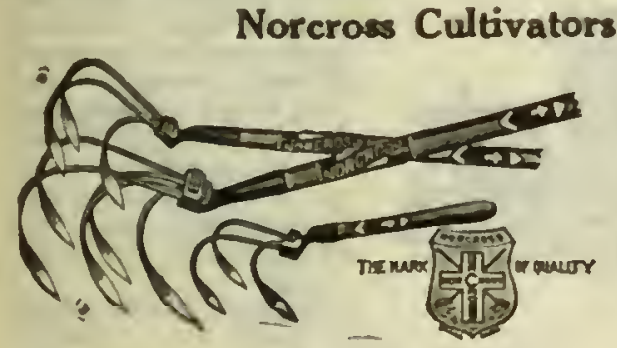

3-prong Garden Cult Ivator $85 \mathrm{cts}$.

5-prong Garden Cultivator $\$ 1.25$.

Midget, 3 prong 50 cts.

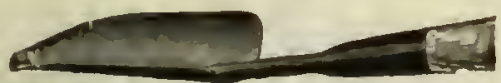

Stoel Garden Trow1s, $50 \mathrm{cts}$. and $75 \mathrm{cts}$. each. Galranized Trowls, 25 cls. each.

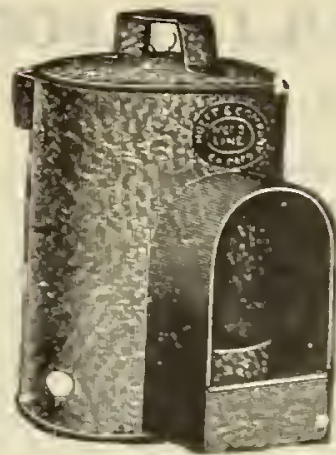

Wall Fountain.

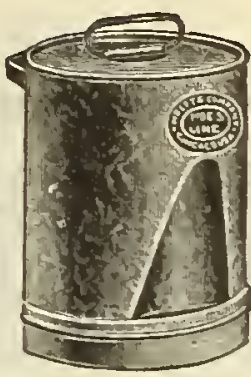

Moo's Wall Fountain.

\section{Wall Fountain}

The covered outlet keeps out dust and dirt, and a removable plate prevents any floating rubbish from being drawn into the reservoir.

No. 97 Capacity 2 quarts, each..............\$.90

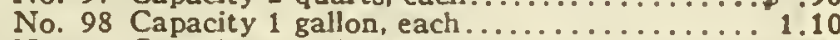

No. 99 Capacity 2 gallons, each............... 1.50

\section{Moe's Wall Fountain}

A practical and convenient fountain. Has removable bottom, easily kept clean. Capacity about 1 gallon. No. 26A, each.......................\$1.00

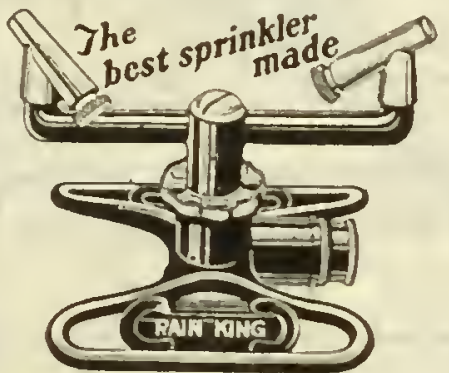

Rain King Sprinklers, each...............\$3.50 Size 2 Sprinklers, each.

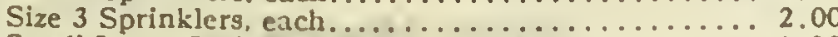
Small Lawn Sprinklers, round, $75 \mathrm{c}$ and............. 1.00 Rainbow Sprinkler........ 2.50
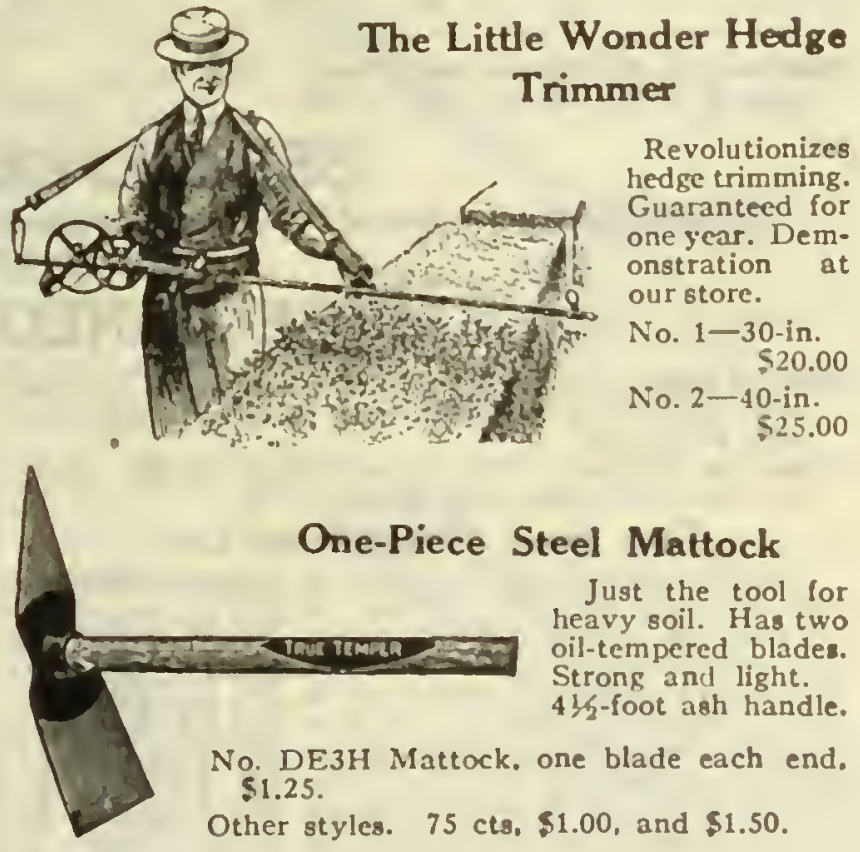

Dalry Thermometers. $\$ 1.00$ each.

Wo carry in tock many new tyles of Garden Tools. Owring to lack of space, wo had to omit many. 


\section{Planet Jr. Farm and Garden Implements}

Thousands of people are now cultrating gardens who have never done so before; thousands of people, therefore, are mating a large saring in the ir Jing expenses and finding out, perbaps for the first time in thelr lives, what fresh peas, beans and corn taste Itse when they are right out of the garden. The labor of cultivating these gardens is onde easy by the ase of Planet Jr. Seed Drills and Wheel Eoes, as is shown by the fact that mang of the most enthustestle gardeners of recent years are women.

The name "PIAFรT JR." has become gynonjmong with labor-8aving among farmers and gardeners overjwhere, and they lestlnctively want the Implement that bears the PIANET JR. trade-mark.

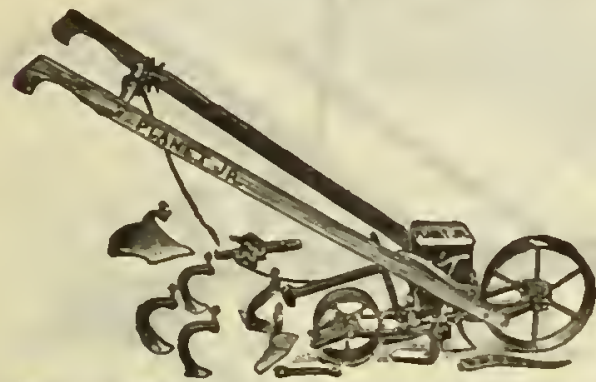

No. 4 Planet Jr. Comblned HIll and Drll Seeder and Slngle Wheel Hoo.

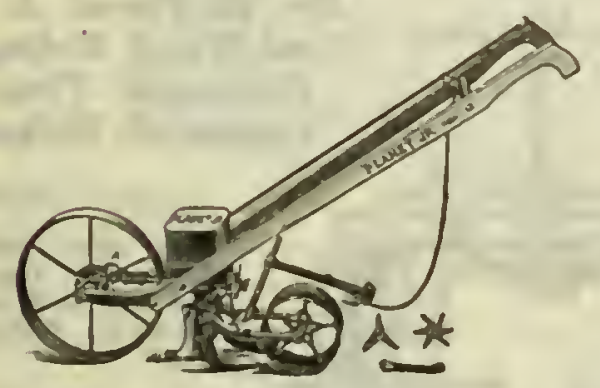

To. 5 Hill and Drill Seedor.

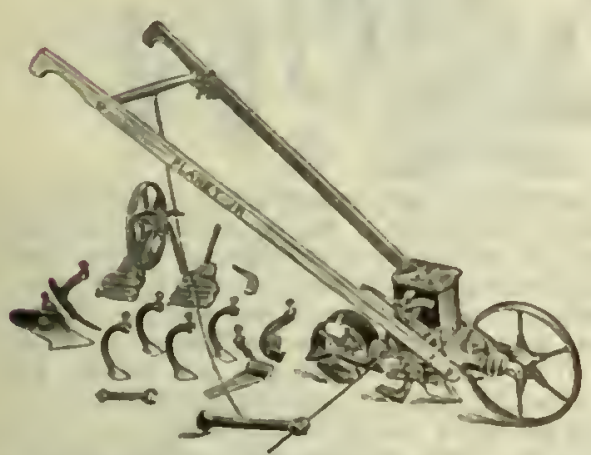

Ko. 2s Planot Jr. Comblned Hill and Drill Seeder and Double Wheel Hoe.

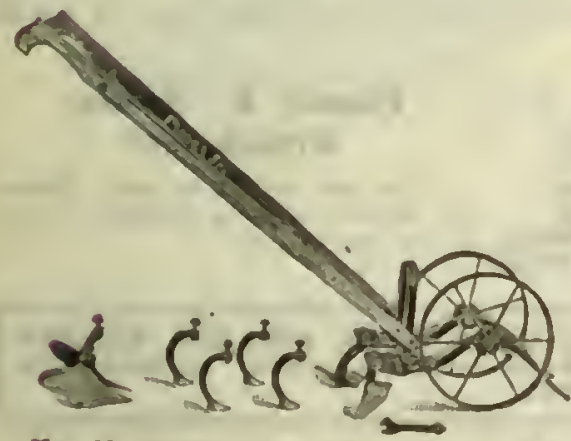

Xo. 12 Pladet Jr. Double Wheel Hoe.
No. 16. Single Wheel

Hoe. Designed to do all work required in the small garden: plowing, cultivating. hoeing and raking. It is very light, and can therefore be easily carried about ........\$9.00

No. 17. Single Wheel Hoo. Identical with No. 16 , excepting that the two rakes and leaf guard are not supplied ..... $\$ 7.75$

No. 19. Single Wheel Hoo. A medium priced wheel hoe with all the attachments necessary for cultivating a small garden............. \$6.00 No. 4. Combined Hill and Dringle Wheel Hoe. The small grower should select one of the combined machines. The drill attachment will not be used as often as the hoeing and cultivating tools, but will be a source of much saving. Thls machine is a special favorite. There are probably more of them in use in the world than any other seeder made. As a Hill and Drill Seeder it op as the furrow, deposits the oeed, covers it and rollo It. either in dirills or hills. Holds $24 / 5$ qts. Price ........\%18.00

No. 5. 1711 l and Drill Seeder. This sceder holds 5 quarts and is the beat sceder made for market gardencrs. Price. $\$ 20.00$.

No. 12. Double and Single Wheel Hoe Corn. blned. The arch ls high cnough to straddle a row until plants are 20 inchc: hlgh: this Insures close work. It can be altered into an admirable single whcel hoe for worklng between rows. Price, \$10.75

No. 25. Comblned IIIII and $D \times 111 \mathrm{~S}$ e d o $\mathrm{r}$, Double and Singlo Wheel Hoe. This ma. chlne as a sceder is practically the same as No. 4 ; sows ln drills or drops in hills $4,6,8,12$ or 24 ins. apart. Holds $21 / 5$ qts. Price.......... \$21.50

No. 119. Single Wheel Hoo. This plow has 24 Inch wheel and mamc guallty as other Planet Jr. Plows. Price. $\$ 4.75$

[ 81 ]

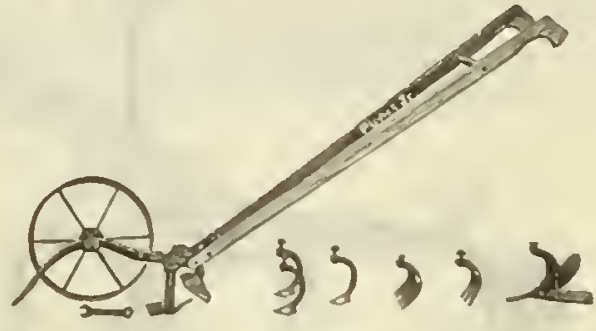

No. 16 Planet Jr. Single Wheel Hoe.

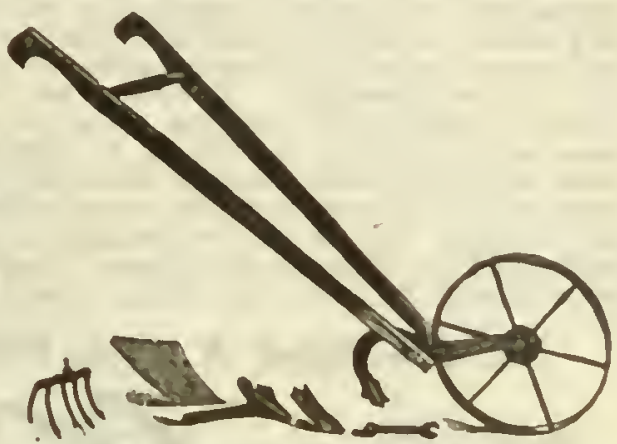

No. 19 Planet Jr. Slaglo Wheel Hoo.

Fire Fly Plow. This wheel hand plow will throw a furrow four to gix incher wide and one to three inches deep.

Price......... \$4.25

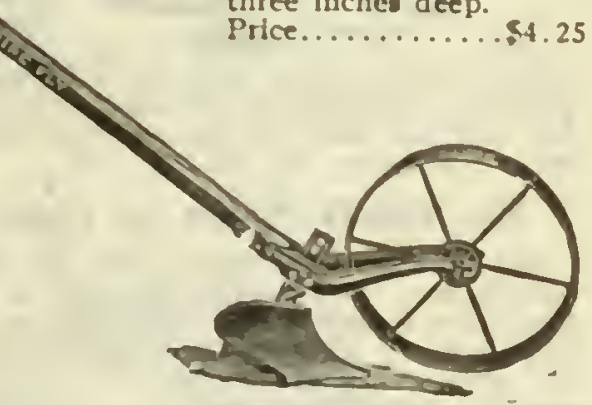

Fire-Fly Hand Plow.

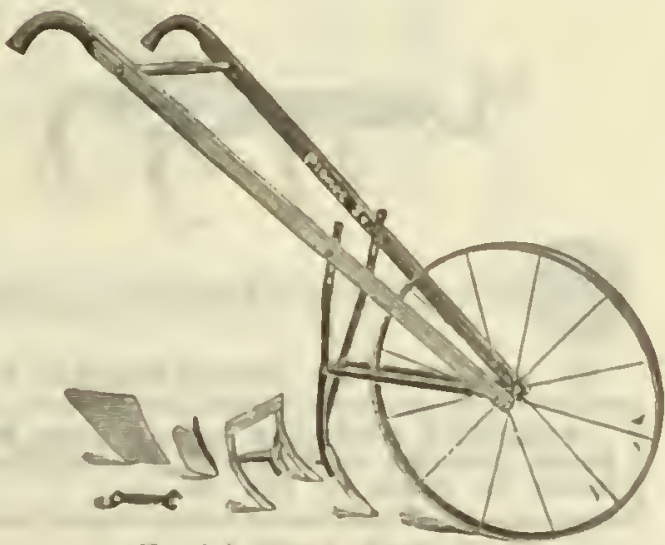

No. 119 Single Whoel H00. 


\section{PLANET JR. TOOLS-Continued}

You cannot afford to till the ground without Planet Jr. tools. They not only save hard labor, but enable you to cultivate double the acreage in the same time, and thus add over 100 per cent to your crop yield. Invented by a practical farmer and manufacturer-the result of fifty years' experience. Strong, lasting construction. Fully guaranteed.

No. 9 Planet Jr. Horse Hoe and Cultivator

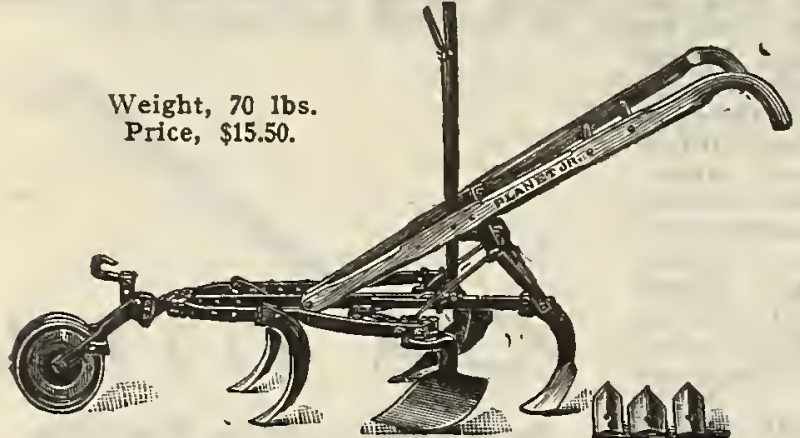

These Planet Jr. Horse Hoes and Cultivators are stronger, better made and finished than any other one-horse cultivators, and enable you to increase your yield, because they do a greater variety of work in corn, potatoes, cotton, beans. tobacco and other crops requiring similar cultivation, and do it more thoroughly. Cultivate deep or shallow, in different width rows, and the extra-long frames make them steady running. All Planet Jr. cultivator steels are made of beveled steel, thickest down the center, making them self-sharpening, and the points retain their shape and strength. No. 9 has lever expander, allowing quick adjustment for different width rows. Used with or without a wheel. No. 9-D, without wheel, price $\$ 14.50$;

No. 4-D Planet Jr. Plain Cultivator

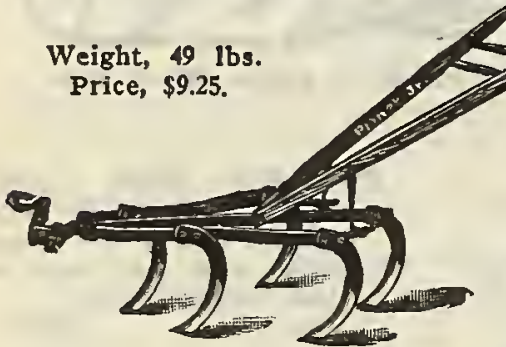

This tool is strong and simple, it has patent handle braces: very firm, simple and convenient. With them the frame and handles seem almost like one solid piece. Changes in width are quickly made by loosening one nut on each side, and one side may be opened wide, while the other is closed. An every-day all-day tool.

\section{No. 100-D Planet Jr. Plain Cultivator}

We offer this Cultivator with the object of filling a definite need where lands are light or where farming is 42 pounds. It will stand hard usage and do excellent work. A steady running tool and easy to handle and adjust.
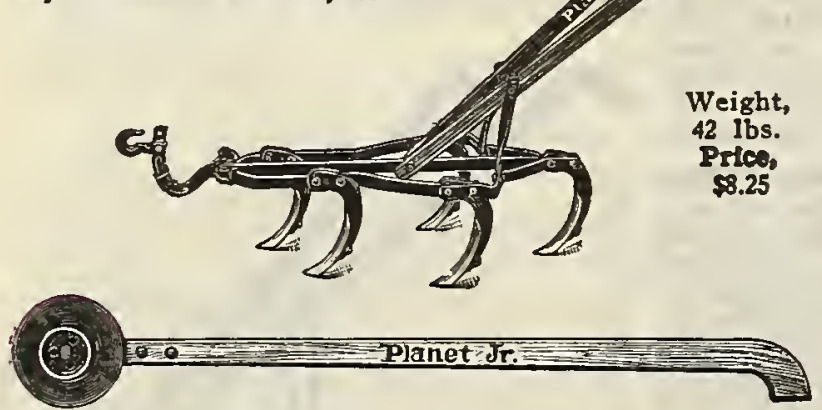

No. 2 PLANET JR. GRASS EDGER, $\$ 1.60$ each

FRIIGFT PREPAT to any point in North or South Carolina on PIANRT JR. TOOIS at prices isted on pages 61 and 62 .
No. 90 Planet Jr. Twelve-Tooth Harrow, Cultivator and Pulverizer

Complete with Steel Wheel,

$\$ 18.00$. Weight, pkd. 74 lbs.

No. 90-B (Without Pulverizer),

To. $90-D$ (Witho

Pulverizer), $\$ 11.75$.

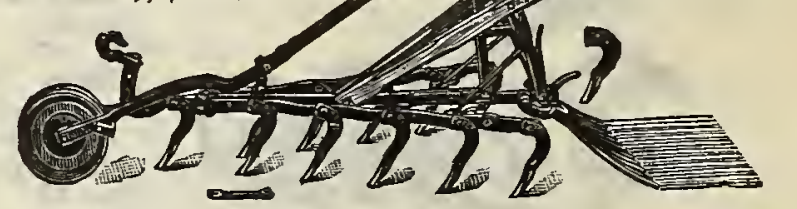

This tool is a special favorite with strawberry, tobacco and sugar-beet growers, market gardeners and farmers, because of its twelve chisel-shaped teeth. The teeth and pulverizer leave the ground in fine condition. Cultivates any width from 12 to 32 inches.

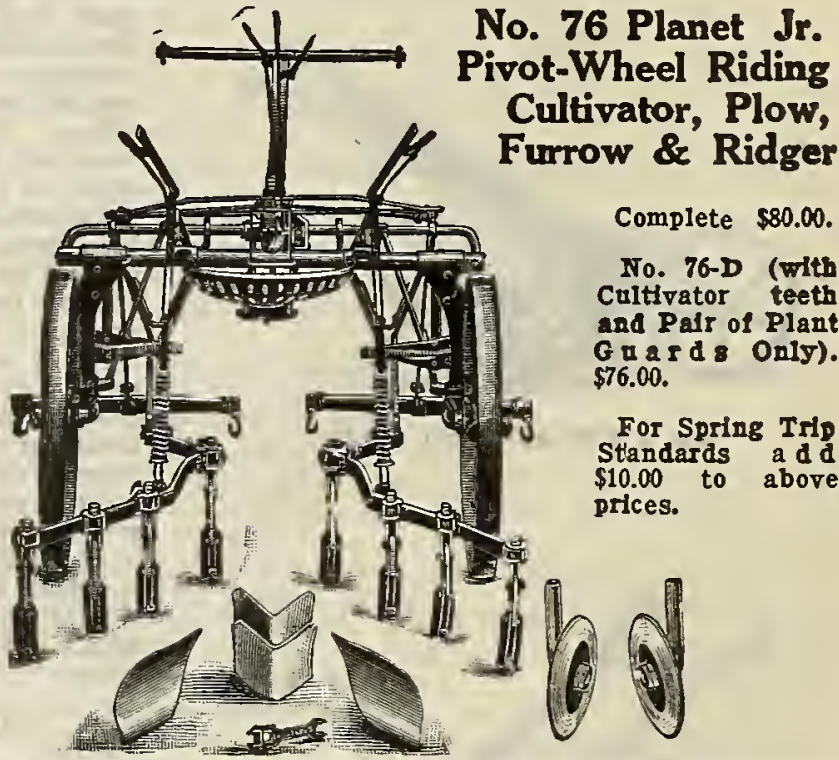

A one-row machine, strongly constructed, easily handled, that has no equal anywhere. Its superior construction, almost entirely of steel, accurate-fitting parts, spring lifting levers and variety of cultivating attachments make it yield big dividends in time and labor saved. The arch is extra wide and 34 inches high, and will work corn safely up to 4 feet. The frame and tongue are steel. Pivot wheels change in width easily to suit different width rows. The gang frames are extra heavy, but improved levers with lifting springs make their control easy. Has malleable pivots and steel axles, both practically dust-proof; steel ratchets and pins. The center lever operates the hinged tongue, regulating the depth of the front teeth and leveling the machine; the same lever moves the teeth instantly. elther closer to or further from the row, while the team is in motion. Cultivates, plows, and hills crops 28 to 44 inches apart.

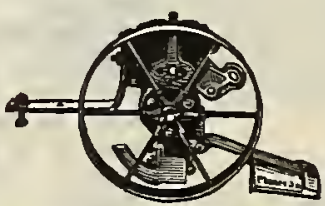

\section{Planet Jr. Seeder} Attachment

Fits and works on any Planet Jr. Wheel Hoe or Garden Cultivator. $\$ 6.50$ each

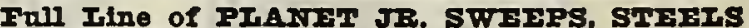
and IPPATES are always carried in gtocl for prompt shipment. 


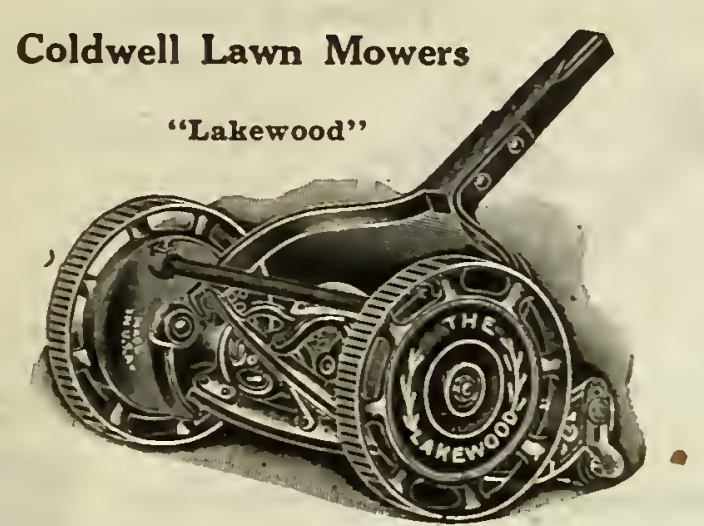

JThe "Lakewood" is a ball-bearing, 4-blade Mower, carried in 16- and 18-ineh sizes. \$12.50.

The "Colonial" is a medium-priced ball-bearing machine, ow wheels. 16- and 18-ineh sizes. \$10.50.

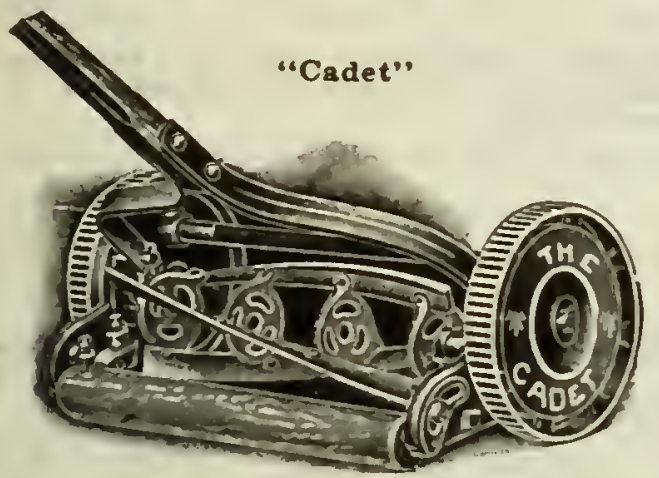

The "Cadet" is a low-priced plain bearing Mower. giving universal zatisfaction. Carried in stock in 14-, 16and 18-inch sizes. 14 and 16 inch, $\$ 8.00 ; 18$ Inch, $\$ 8.50$.

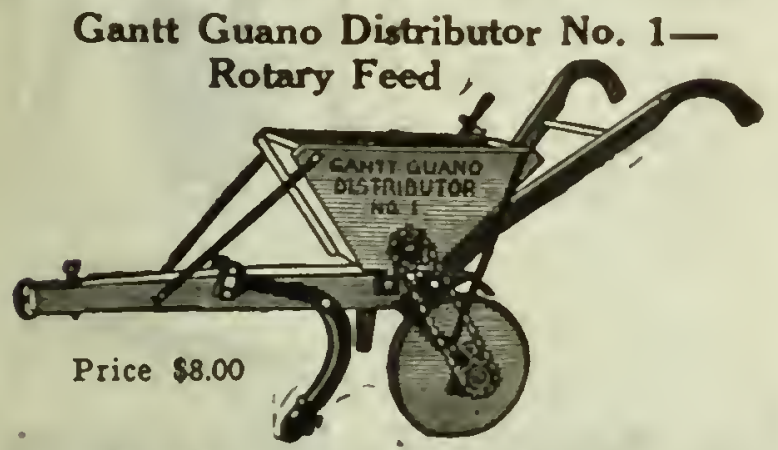

Strongest, most perfect made. Far superior to anything on the market. Unsurpassed for putting out all kinds of guano; easily regulated to distribute the proper amount; no waste in turning rows. The Gantt patent cotton planters and guano distributors are the best implements for the purpose ever put on the market. Satisfaction guaranteed.

\section{Gantt Guano}

Distributor No. 2 Price $\$ 9.00$

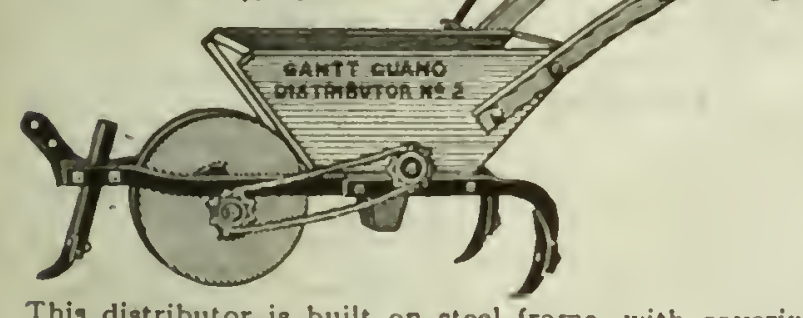

This distributor is built on stcel frame. with covering plowis to list or bed on guano when put out. It opens the furrow, puts down and spreads the fertilizer, eovers the same, all at one operation, with one man and one horge. The hopper is large and holds nearly twice the amount of guano as some other makes. No waste in turning or going from one field to another. The lever is in easy reach of the operator, and will dlstribute from 100 to 1,000 pounds to the acre.

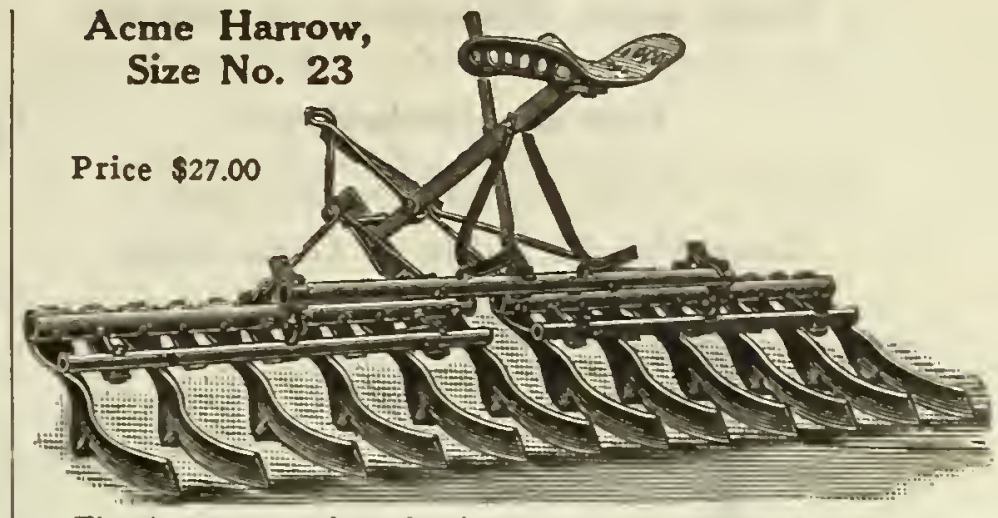

The Acme not only pulverizes, smooths, and turns the surface, but euts through to the under soil, pulverizing and compacting it. It also turns and mixes the soil so that the seed sown is covered evenly with fully pulverized soil. Insuring a quick catch under the most favorable conditions for best germination. Size No. 23, for two horses, has a wrought-iron tubular bar, to which are attached two gang bars, which can be used either flexible or rigid, each provided with six curved cast-steel coulters, supplemented by flat cast-steel crushing spurs. This size Harrow works a space $63 / 2$ feet wide.

Size H-One-Horse Acme Harrow with eight coulters... $\$ 20.00$

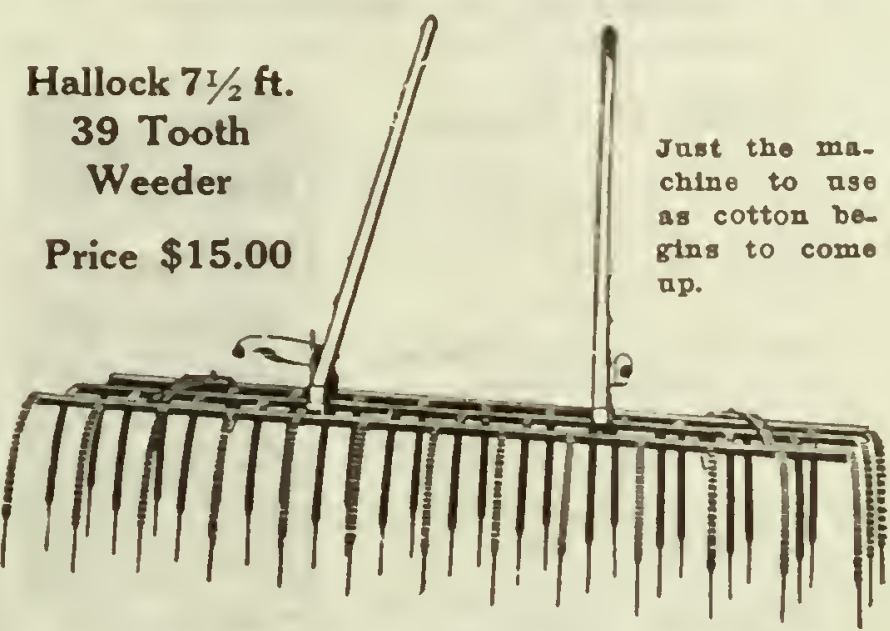

Iron Age Cultivator No. 78 Low Wheel and No. 68 High Wheel

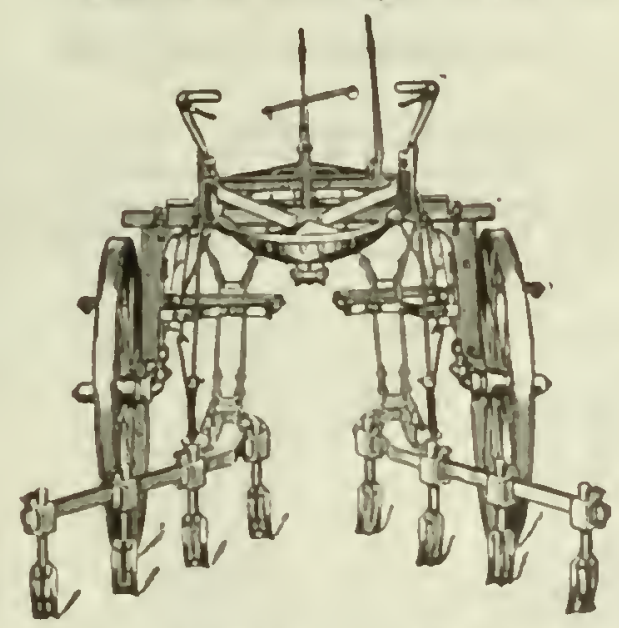

All-Steel Pivot Wheels, Pivot Gangs, Parallel Motion. Perfeetly Adjustable. Balance Frame Steel Construction makes them both strong and rigld, and yet light-steel pipe, solid steel neek yoke, steel frame, inverted angle Iron arch, one-piece stecl axle standards (or shinbones), steel levers, stecl lock washers on cvery bolt. the simplest but strongest steel gangs you have ever seen. Not a piece of wood in the machine. except the brake pins for the plain hoes.

No. 78 Cultivator $\$ 40.00$. No. 68 Cultivator $\$ 45.00$. 
Grape Bags, Transparent or Opaque

Protects fruit from birds and insects. $\$ 1.00$ per 100 , ppd.

Para Dichlorobenzene

A successful Remedy for Peach Tree Borers. $1 \mathrm{lb}$. can. 50 cts., 5 lbs. $\$ 2.25$. Ask for prices large quantities.

\section{Long Handle Sickle or Grass Blade}

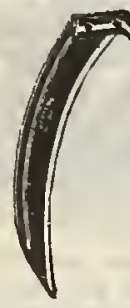

\section{$\$ 1.25$.}

\section{Sickles or Grass Hooks}

50 cts., 75 cts. and $\$ 1.00$ each.

\section{Egg Box}

Especially recommended for setting eggs.

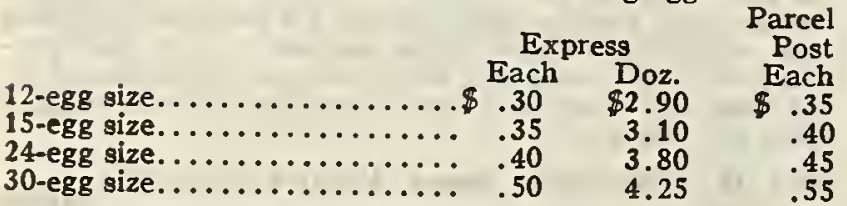

\section{FORMALIN OR FORMALDEHYDE}

For treating potato houses, etc. $50 \mathrm{cts}$. per 1-lb. can.

\section{Collins Oat Sprouter}

Sprouted oats are recognized as the only practical, sensible and effective way of furnishing poultry green feed.

Made of galvanized iron.

Nests in Corrugated Boxes 4 Inches High

5 Pans-11x15, small back yard size. Weight 9 lbs. $\$ 3.00$.

8 Pans-11x15, the popular size. Weight 14 lbs. $\$ 4.00$.

8 Pans-11x32, for BIG Business. Weight 28 lbs. $\$ 8.00$.

Tobacco Barn Thermometers

Very best grade 75 cts. and $\$ 1.00$, postpaid.

MANNS GREEN BONE CUTTER.

No. 7, each.....................\$19.75

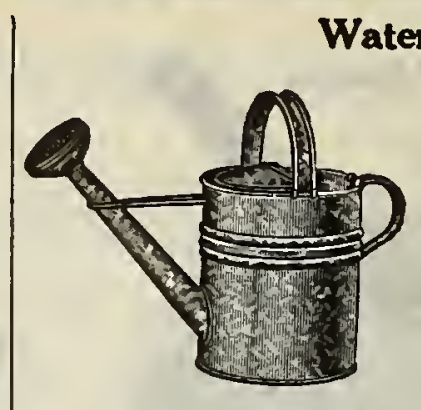

Watering Cans

Regular Style

Round regular style heavy galvanized iron, one rose unscrews to clean. Shipped by express only.

6 qt. capacity .......\$1.00

8 qt. capacity........ 1.25

10 qt. capacity.......... 1.50

12 qt. capacity........... 1.75

Tin Watering Cans-20 per

cent. less than galvanized.
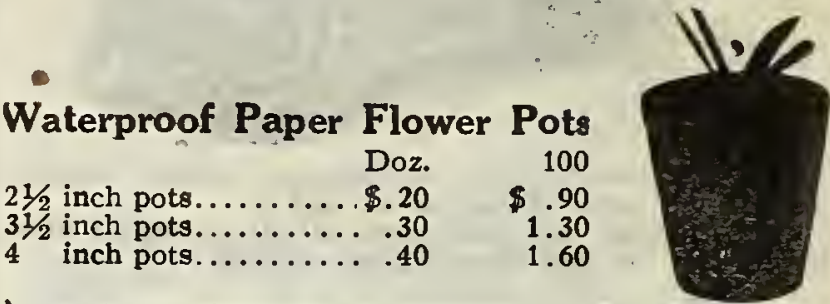

AVICOL for chicken cholera, etc., 500 pkgs. KLIX (Sodium Floride) for chicken lice, 35 cts. and $65 \mathrm{cts}$.

\section{Magic Weeders}

These spring tooth weeders are strong in construction and very popular.

\section{A. 51/2-inch han- \\ dle......\$ $\$ 0.20$}

B. 18-inch handle .30

D. 6-inch handle. .50

F. 42-inch handle, no blade .85

H. 48-inch handle, with blade...... 1:50

\section{BEICA 1 BD. 8} COMBINATION SPRINO-TOOTH Magie Weedèr Hoce

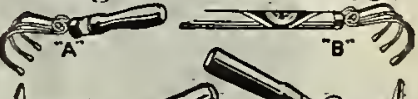

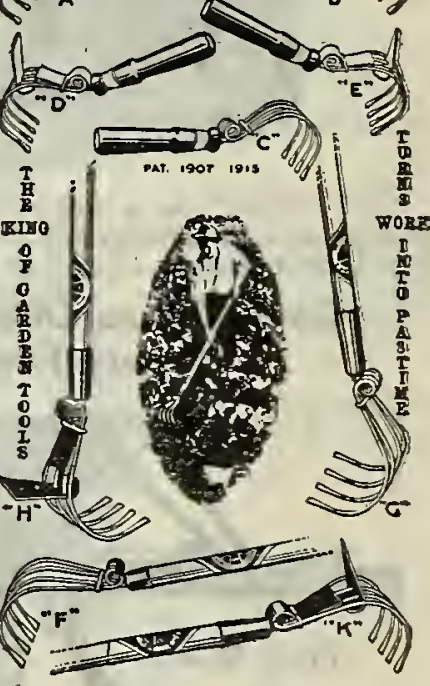

"The Multitool"-The Ball Bearing Hoe $\$ 4.00$ each

$\$ 10.00$ CASH IN PRIZES $\$ 2.50$ for the largest Tomato. $\$ 2.50$ for the largest Pumpkin.

$\$ 2.50$ for the largest Watermelon. $\$ 2.50$ for the largest Cabbage.

The only conditions are that you must specify, when ordering seeds, your desire to enter the con test Prizes will be awarded as soon as vegetables have been judged at our store.

Garden Seeds and Plants.

Asparagus.

Beans, Bush ..................

Beans, Was...............2, 6

Beans, Pole............... 6

Beans, Lima...............2, 7

Beets....................

Broccoli .......................

Cabbage.................., i0

Cabbage Plants, etc............11

Cabbage, Chinese............12

Carrots.......................... 12

Cauliflower.....................12

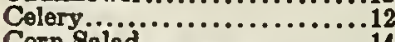

Corn Salad...................

Corn (Sweet or Sugar)..........13

Corn, Pop....................14

Collards........................

Cuoumbers....................2, 16

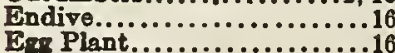

\section{INDEX}

Gourds ....................16

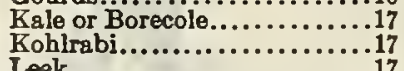

Leek ............................17

Lottuce.........................18

Mangel-Wurzel...................

Martyna.........................

Mustard Gumbo..................

Onions $\ldots \ldots \ldots \ldots \ldots \ldots \ldots \ldots .22$

Onion Sets..................22

Parsley.........................21

Parsnips......................21

Pepper..................... 24, 24

Potato Plants (Sweet)..........11

Pumpkin......................24

Radish......................., 26

Rutabaga.........................

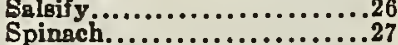

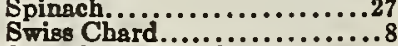

Swiss Chard..... iling..........8.

Tobroco.......................31
Tomatoes..............3, 28, 29

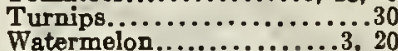
FLOWER SEE D. $. . . . .4,3,2$ BULBS............42, 43, 44 Farm Seeds

Alfalfa.......................46

Beans (Navy) ....................

Beans (Navy) $\ldots \ldots \ldots \ldots \ldots \ldots \ldots .49$

Beans (Velvet).............49

Broom Corn.................48

Canada Field Peas..............

Cane or Borghum..............49

Clover.........................46

Cow Peas.....................50

Cow Peas (Table)...........49

Corn........................5

Cotton ......................

Grass (Lowp)...............45

Grass (Field or Pasture) ......4

Millet.......................51

Milo Мaire......................
Peanuts..................48 Rape.......................48 Rye ........................51 Syntower. Vetches

Wheat.........................51 Miscellaneous

Farmogerm................48 Farm \& garden implements $61-63$ Fertilizers................ Flower Pots.................... Insecticides \& Fungioides......54 Miscellaneous Supplies.....59,64 Parcel Post Rates.............. Poultry Supplies..57, 58, 59, 60 Poultry Foods \& Ramedies..60 Pruning Shesrs............50, 57 Savo Steal Flower Bö............21 Bpray Pumpe..............55, 56 Surasestions to Customers....... 


\section{JOB P. WYATT \& SONS CO. RALEIGH, NORTH CAROLINA "The Leading Seed House of the Carolinas"}

Job P. Wratt \& Sons Co. cive no warranty, express or implied, as to description, quality, productivenes or any other matter of any seds, bulbs, or plante tbey send out, and will not be responsible for the crop.

Forward by $\left\{\begin{array}{l}\text { State on this line whether want- } \\ \text { ed by Msil, Express or Freight }\end{array}\right\}$

Your Name.

Street Address (if any) R. D.......

Post Office

County State.

Express or Freigbt Office

\begin{tabular}{|l|}
\hline FILLED BY \\
\hline DATE FILLED \\
\hline SUIPPED BY \\
\hline
\end{tabular}

AMOUNT ENCLOSED

P. O. Money Order

Exp. Money Order

Bank Drafn

Cash, Notes \& Silrer

Postrge Stampe

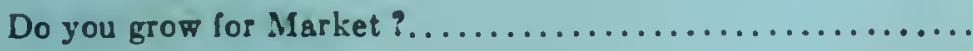

Date.

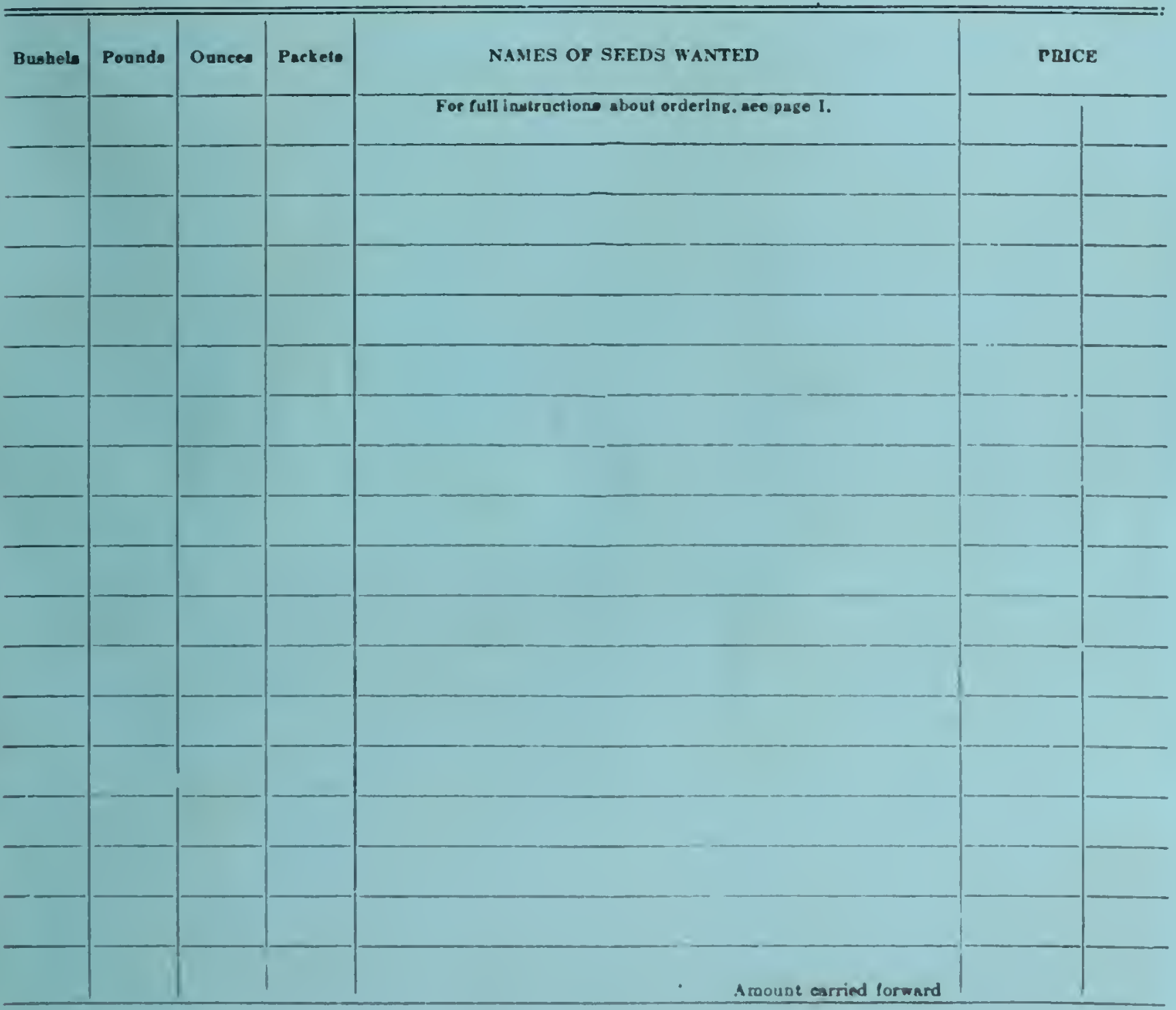




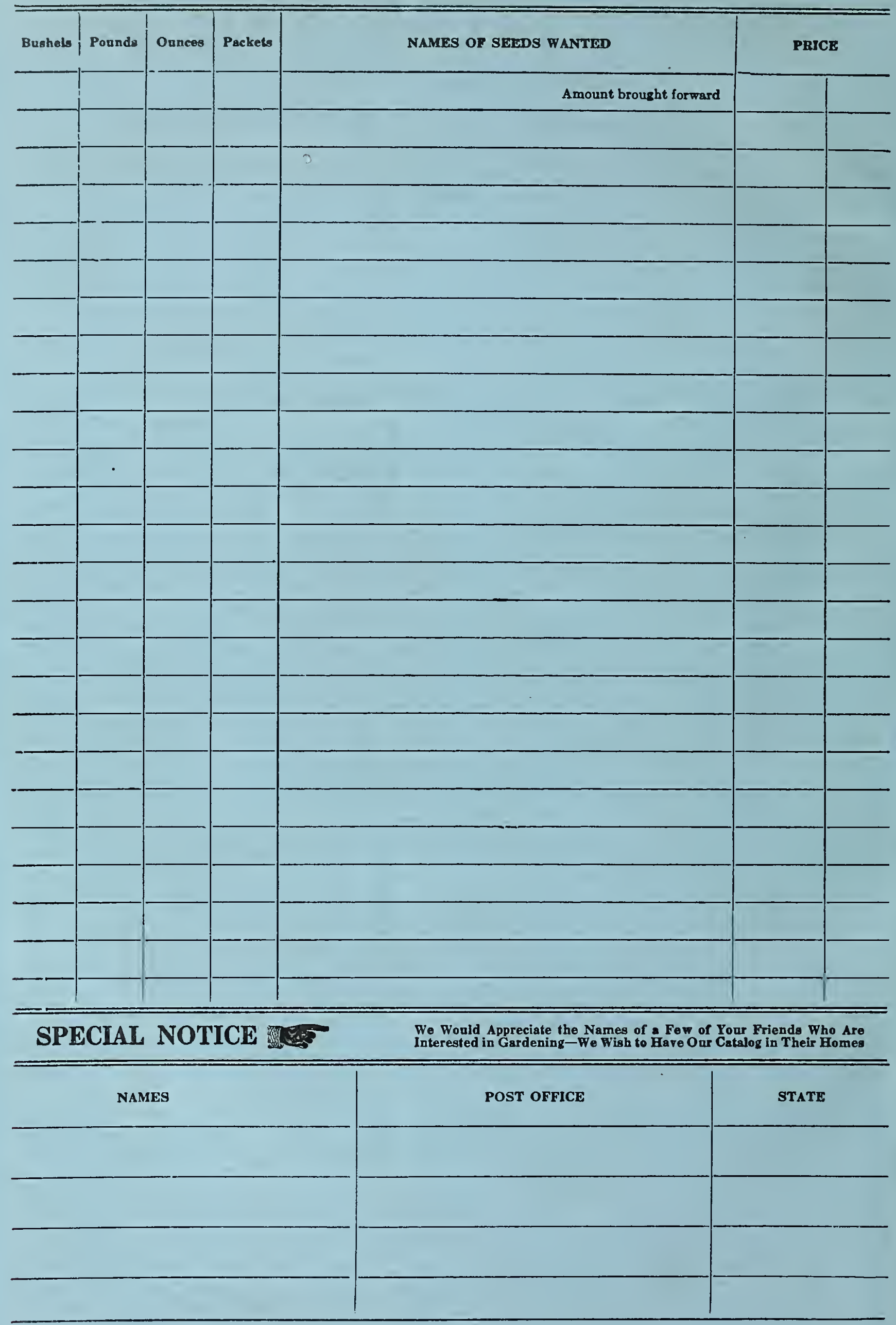



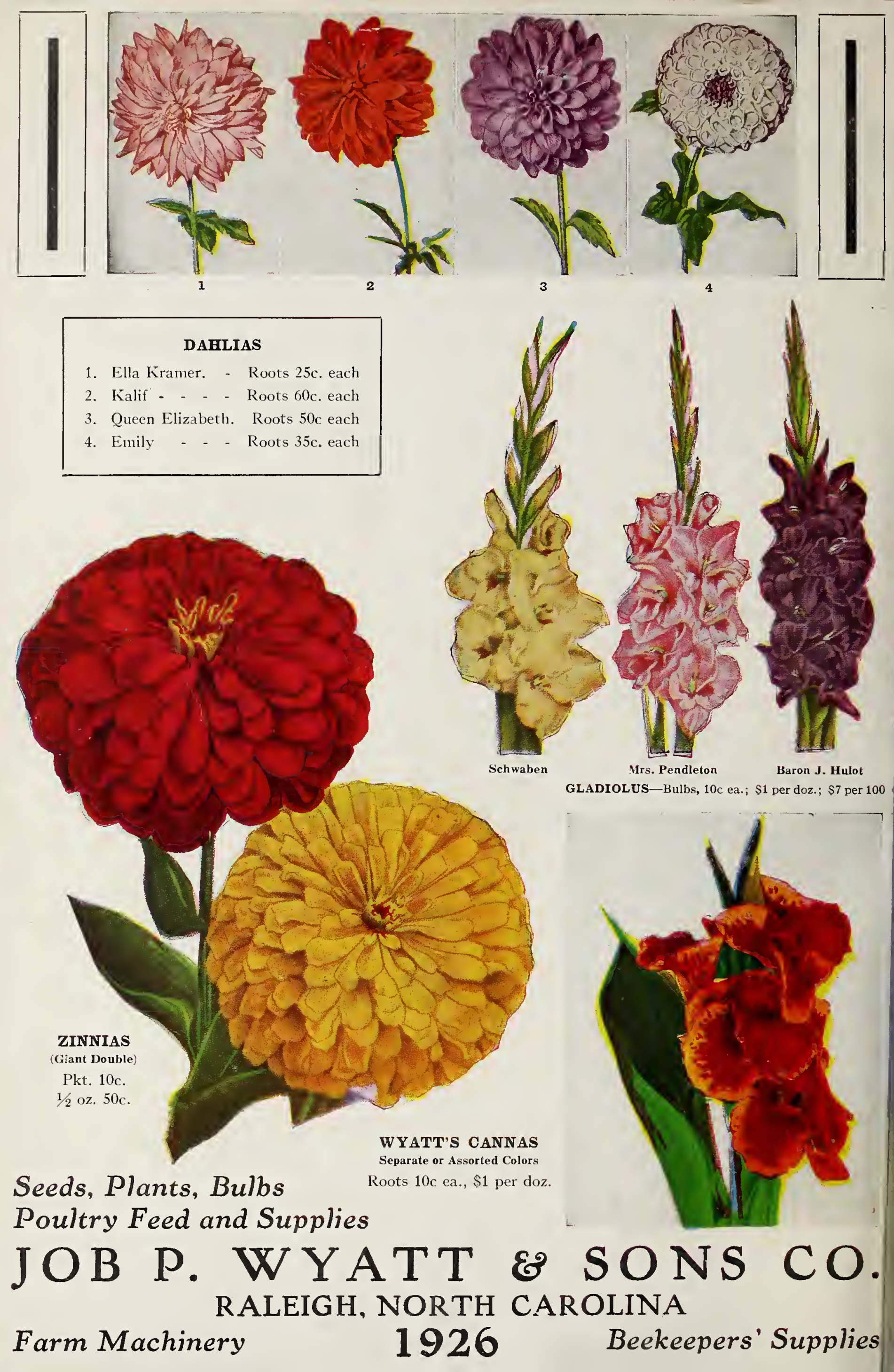